


\section{Alternatieve vloeren voor vleeskalveren}

Auteurs

Jetta Heeres ${ }^{1}$, Maaike Wolthuis ${ }^{1}$, Sjoerd Bokma ${ }^{1}$, Dolf Smits, Norbert Stockhofe ${ }^{2}$, Izak Vermeij ${ }^{1}$ en Kees van Reenen ${ }^{1}$

1 Wageningen Livestock Research

2 Wageningen Bioveterinary Research

Dit onderzoek is uitgevoerd door Wageningen Livestock Research, in opdracht van en gefinancierd door het Ministerie van Economische Zaken en het Productschap Vee en Vlees, in het kader van het Beleidsondersteunend onderzoek thema Dierenwelzijn (projectnummer BO-20-008-001.05)

Wageningen Livestock Research

Wageningen, oktober 2017 
Jetta Heeres, Maaike Wolthuis, Sjoerd Bokma, Dolf Smits, Norbert Stockhofe, Izak Vermeij en Kees van Reenen, 2017. Alternatieve vloeren voor vleeskalveren; Wageningen UR (University \& Research centre) Livestock Research, Livestock Research Rapport 1056.

Dit rapport is gratis te downloaden op https://doi.org/10.18174/425832 of op www.wur.nl/livestock-research (onder Wageningen Livestock Research publicaties).

(C) 2017 Wageningen Livestock Research

Postbus 338, 6700 AH Wageningen, T 03174839 53, E info.livestockresearch@wur.nl, www.wur.nl/livestock-research. Wageningen Livestock Research is onderdeel van Wageningen University \& Research.

Wageningen Livestock Research aanvaardt geen aansprakelijkheid voor eventuele schade voortvloeiend uit het gebruik van de resultaten van dit onderzoek of de toepassing van de adviezen.

Alle rechten voorbehouden. Niets uit deze uitgave mag worden vermenigvuldigd en/of openbaar gemaakt worden door middel van druk, fotokopie, microfilm of op welke wijze dan ook zonder voorafgaande toestemming van de uitgever of auteur.

De certificering volgens ISO 9001 door DNV onderstreept ons kwaliteitsniveau. Op als onze onderzoeksopdrachten zijn de Algemene Voorwaarden van de Animal Sciences Group van toepassing. Deze zijn gedeponeerd bij de Arrondissementsrechtbank Zwolle. 


\section{Inhoud}

$\begin{array}{ll}\text { Woord vooraf } & 5\end{array}$

$\begin{array}{ll}\text { Samenvatting } & 7\end{array}$

$\begin{array}{ll}\text { Summary } & 9\end{array}$

$\begin{array}{llr}1 & \text { Inleiding } & 11\end{array}$

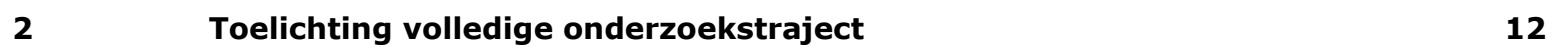

$3 \quad$ Voorstudie $\quad 13$

3.1 Materiaal en Methode $\quad 13$

$\begin{array}{ll}3.1 .1 \text { Proefopzet } & 13\end{array}$

3.1.2 Studie naar ligcomfort 13

3.1.3 Studie naar effect van vloertype op dierkenmerken $\quad 14$

3.1.4 Verkennende studie naar effect van vloertype op de ammoniakemissie $\quad 15$

3.1.5 Eindinspectie vloeren en ervaringen kalverhouders 16

3.1.6 Statistische analyses 16

$\begin{array}{lll}3.2 & \text { Resultaten } & 17\end{array}$

3.2.1 Studie naar ligcomfort 17

3.2.2 Studie naar effect van vloertype op dierkenmerken 18

3.2.3 Verkennende studie naar effect van vloertype op ammoniakemissie $\quad 23$

3.2.4 Eindinspectie vloeren en ervaringen kalverhouders $\quad 24$

$\begin{array}{lll}3.3 & \text { Besluit vloeren praktijkstudie } & 27\end{array}$

3.3.1 Afweging bij keuze van vloertypen voor fase 2: 27

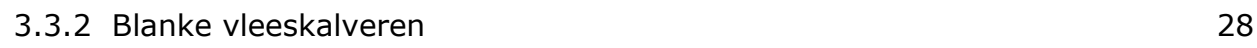

$\begin{array}{ll}3.3 .3 \text { Rosé kalveren } & 31\end{array}$

4.1 Materiaal en Methode $\quad 34$

4.1.1 Materiaal $\quad 34$

4.1.2 Methode/waarnemingen $\quad 35$

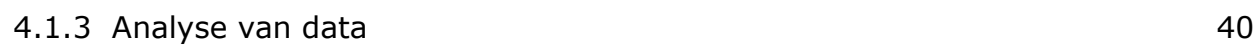

$\begin{array}{lll}4.2 & \text { Resultaten } & 41\end{array}$

4.2.1 Gedrag $\quad 41$

4.2.2 Gezondheid $\quad 43$

4.2.3 Pathologie $\quad 44$

4.2.4 Bevuiling en bezoedeling $\quad 45$

4.2.5 Geslacht gewicht en voeropname $\quad 47$

4.2.6 Gebruik antibiotica en uitval $\quad 48$

4.2.7 Waarnemingen vloeren $\quad 50$

4.2.8 Stalklimaat 53

4.2.9 Waarnemingen demoafdelingen 53

4.2.10Emissiemetingen $\quad 53$

4.2.11Economische evaluatie $\quad 54$

4.2.12Gebruikerservaringen kalverhouders 58

$\begin{array}{lll}4.3 & \text { Discussie } & 60\end{array}$

4.3.1 Waarnemingen dier $\quad 60$

4.3.2 Waarnemingen vloeren $\quad 62$

4.3.3 Waarnemingen stalklimaat $\quad 64$

4.3.4 Waarnemingen demoafdelingen $\quad 64$ 
4.3.5 Ammoniak- en geuremissiemetingen 64

4.3.6 Economische evaluatie 66

4.3.7 Gebruikerservaringen kalverhouders 66

$\begin{array}{ll}\text { Literatuur } & 69\end{array}$

$\begin{array}{lll}\text { Bijlage } 1 \text { Deelnemende kalverhouders } & \mathbf{7 1}\end{array}$

$\begin{array}{lll}\text { Bijlage } 2 & \text { Samenstelling projectgroep en stuurgroep } & 72\end{array}$

$\begin{array}{lll}\text { Bijlage } 3 \text { Vloeren voorstudie } & 73\end{array}$

$\begin{array}{lll}\text { Bijlage } 4 & \text { Vloeren praktijkstudie } & 74\end{array}$

$\begin{array}{lll}\text { Bijlage } 5 & \text { Protocol klinische gezondheid } & 77\end{array}$

$\begin{array}{lll}\text { Bijlage } 6 & \text { Protocol pathologie longen } & 78\end{array}$

$\begin{array}{lll}\text { Bijlage } 7 & \text { Protocol bevuiling } & \mathbf{8 0}\end{array}$

$\begin{array}{lll}\text { Bijlage } 8 & \text { Overige resultaten praktijkstudie } & 81\end{array}$

$\begin{array}{lll}\text { Bijlage } 9 & \text { Foto's ondervloer na weghalen toplagen } & \mathbf{8 5}\end{array}$

$\begin{array}{lll}\text { Bijlage } 10 & \text { Tribo rapportage } & 86\end{array}$

$\begin{array}{lll}\text { Bijlage } 11 & \text { Resultaten demoafdelingen } & 95\end{array}$

Bijlage 12 Vragenlijst enquête beloopbaarheid en levensduur 96

Bijlage 13 Afschrijvingsscenario's gebruikers en leveranciers 100

Bijlage 14 Vragenlijst enquête kalverhouders 102 


\section{Woord vooraf}

PANTA RHEI. Alles stroomt, alles verandert, niets blijft hetzelfde. Deze uitspraak van de Griekse filosoof Heraclites (ca. 475 vChr.), vind ik wel passen bij de sector vleeskalveren.

De veranderingen in de houderij van vleeskalveren zijn eigenlijk best wel spectaculair. Vandaar deze filosofische uitspraak. Ter illustratie een conclusie uit het rapport van de commissie veehouderij welzijn dieren (waarin gedragsonderzoekers, de Dierenbescherming en de veehouderijsector vertegenwoordigd waren): "Groepshuisvesting met groepsvoedering lijkt geen goed alternatief voor het huisvesten van vleeskalveren in individuele boxen" (1975).

Via discussies over centimeters box breedte in de begin jaren tachtig van de vorige eeuw, waar ik als referendaris vierde klas verslag mocht leggen van het zogenoemde tripartite overleg, is er een transitie geweest naar groepshuisvesting, waarbij ook de voeding met uitsluitend kunstmelk aangevuld is met enig ruwvoer/krachtvoer. Vanuit de voorloperpositie van Nederland is groepshuisvesting nu de norm in de hele Europese Unie. De vleeskalversector moet steeds in het Europese perspectief geplaatst worden. De aanpassingen zijn steeds gevolgd op onderzoek naar plussen en minnen van de beoogde verandering. Groot was dan ook de verbazing in de sector dat de Minister voor landbouw in de Nota Dierenwelzijn (2007) aangaf dat kalveren voortaan op een met rubber bedekte bodem moesten worden gehouden. Hiermee was geen ervaring opgedaan en er waren ook geen voorbeelden beschikbaar voor de praktijk. Gelukkig voor de sector kwam de Kamer met een motie die om een grootschalig onderzoek vroeg naar de mogelijkheden en de voor- en nadelen van dergelijke vloeren, alvorens deze voor te schrijven.

Met dank aan de financiers, het ministerie van Economische Zaken en het Productschap Vee en Vlees, is een meerjarig onderzoekprogramma opgezet. Met de bereidwillige medewerking van kalverhouders zijn diverse vloersoorten uitgetest in een eerste fase. Met een beperkt aantal vloeruitvoeringen, waaraan de kalveren zelf de voorkeur gaven (methode Welfare Quality), is vervolgens een tweede fase van het onderzoek uitgevoerd, waarin alle praktische aspecten zijn onderzocht. Ook hiervoor is een woord van dank op zijn plaats aan alle kalverhouders (bijlage 1), die meerdere jaren minimaal 3 afdelingen op hun bedrijf ter beschikking stelden aan het onderzoek.

De resultaten van deze benadering en dit onderzoek, gaan verder dan beschreven in deze rapportage. We zien dat de vloerfabrikanten verder gaan met de ontwikkeling van vloeren met een zachtere toplaag en dat er kalverhouders zijn die bij ver- of nieuwbouw nu al kiezen voor de nieuwe vloeren. Het onderzoek heeft duidelijk een olievlekwerking.

Behalve een woord van dank aan de kalverhouders, ook een woord van waardering voor de onderzoekers en de geconsulteerde dierenartsen (Teus Kreuger van DGZ Boven-Veluwe en Annet van Uchelen van DAP Thewi), die hun creativiteit vaak tot het uiterste moesten aanspreken, om te komen tot vergelijkbare gegevens op heel verschillende praktijkbedrijven. De onderzoekers werden hierbij gesteund door een projectgroep (zie bijlage 2) uit de kalverhouderij, die actief mee dacht over het verenigen van wetenschappelijke noodzaak met praktische mogelijkheden. Dank voor jullie inzet. De opzet, planning en begroting van het onderzoek werd bewaakt door een stuurgroep (zie bijlage 2), met daarin het ministerie van Economische Zaken, de vleeskalversector, de Dierenbescherming en het Productschap Vee en Vlees (later opgevolgd door de Stichting Brancheorganisatie Kalverhouderij), met ondergetekende als onafhankelijk voorzitter. Het was mij een genoegen.

Jan Klaver

Voorzitter Stuurgroep 


\section{Samenvatting}

Het onderzoek naar alternatieve vloeren voor vleeskalveren bestond uit twee onderdelen: (i) een voorstudie en (ii) een grootschalige praktijkstudie. In de voorstudie werden vijf alternatieve vloertypen bij blankvleeskalveren onderzocht (respectievelijk: beton, ICE, Easyfix, Van Beek rubber op beton, en Van Beek rubber op hout) en zes alternatieve vloeren bij rosékalveren ( respectievelijk: hout, ICE, Easyfix, Van Beek rubber op beton, Van der Velden Beton, en Kraiburg). De voorstudie werd uitgevoerd op vier vleeskalverbedrijven in de praktijk, twee blankvleesbedrijven en twee rosébedrijven. In de voorstudie werd enerzijds specifiek gekeken naar het ligcomfort op basis van een keuzeproef, en anderzijds het effect van de verschillende vloertypen op gedrag en gezondheid van vleeskalveren in kaart gebracht. Voor de keuzeproef werden hokken gebruikt waarvan de ene helft van het vloeroppervlak uit de referentievloer bestond (i.c. houten roosters voor blankvleeskalveren, en betonnen roosters voor rosékalveren), en de andere helft uit een alternatiefvloertype. Op twee leeftijden werd vervolgens gedurende 24 uur vastgelegd op welk hokoppervlak de kalveren hun liggedrag lieten zien. Voor het bepalen van het effect van vloertype op gedrag en gezondheid werd gebruik gemaakt van hokken waarvan de gehele vloer met de referentievoer of één van de alternatieve vloertypen was uitgerust; in totaal 12 hokken per vloer. In de voorstudie werd ook een verkennend onderzoek gedaan naar het effect van vloertype op ammoniakemissie. Zowel blankvleesals rosékalveren hadden een voorkeur voor een relatief zachte vloer als ligoppervlak. Ten opzichte van de referentievloer was de frequentie uitglijden bij blankvleeskalveren lager op ICE en Easyfix, en bij rosékalveren lager op de Easyfixvloer. Bij blankvleeskalveren werd op ICE en Easyfix in vergelijking met de referentievloer een lagere prevalentie dikke knieën gezien. In het verkennende emissieonderzoek werden geen effecten van vloertype op de ammoniakemissie gevonden. Op grond van de resultaten van de voorstudie werd geconcludeerd dat van de onderzochte alternatieven de vloeren van ICE en Easyfix vanuit het oogpunt van dierenwelzijn perspectief lijken te geven op verbetering, en verder onderzocht kunnen worden in de grootschalige praktijkstudie.

De praktijkstudie werd beschouwd als de "lakmoesproef" van het project, op grond waarvan gefundeerde conclusies getrokken zouden kunnen worden over effecten van alternatieve vloertypen op welzijn en (technische) prestaties van vleeskalveren onder praktijkomstandigheden. In totaal 14 vleeskalverbedrijven in de praktijk hebben aan de praktijkstudie deelgenomen, 6 rosébedrijven en 8 blankvleesbedrijven. Op elk bedrijf waren drie gehele afdelingen beschikbaar voor het onderzoek. Binnen elk bedrijf werden drie vloertypen, respectievelijk de referentievloer (houten roosters voor blank en betonnen roosters voor rosé), ICE en Easyfix, middels loting over de drie afdelingen verdeeld, en vervolgens werden alle hokken binnen de afdeling met de juiste vloer uitgerust. Op de blankvleesbedrijven zijn waarnemingen gedaan gedurende vier opeenvolgende mestrondes, en op rosébedrijven gedurende vijf opeenvolgende mestrondes. Er zijn waarnemingen gedaan aan het gedrag van de kalveren, in het bijzonder uitglijden, de gezondheid van de dieren op het kalverbedrijf, met het accent op de gezondheidstoestand van de gewrichten, de bevuiling (gedetailleerd per kalf op het kalverbedrijf en, vanuit het oogpunt van hygiëne tijdens het slachtproces, groepsgewijs bij aankomst op het slachthuis), het gebruik van antibiotica, de pathologische toestand van de longen na slachting, de voeropname, en het karkasgewicht na slachting. Daarnaast zijn op twee speciaal daarvoor geselecteerde blankvleesbedrijven volgens een case-control opzet ammoniak- en geuremissiemetingen uitgevoerd. Ook zijn op één blankvleesbedrijf en één rosébedrijf dynamische stroefheidsmetingen uitgevoerd op de referentievloeren en de alternatieve vloertypen. Tenslotte is een economische evaluatie uitgevoerd. Op de Easyfixvloer was bij blankvleeskalveren de kans op uitglijden twee weken voor het slachten lager dan op de referentievloer. Zowel bij blankvlees- als rosékalveren was de prevalentie van dikke knieën onder dieren gehuisvest op ICE of Easyfix significant lager ten opzichte van dieren gehuisvest op de referentievloer. Andere klinische parameters verschilden niet tussen de referentievloer en de alternatieve vloertypen. Kreupelheid en lesies aan klauwen en gewrichten werden in het onderzoek nauwelijks gezien. Bij blankvleeskalveren en bij rosékalveren had het vloertype geen effect op het gebruik van antibiotica of op de uitval. Ook het vóórkomen van 
beschadigingen aan de longen werd niet door het vloertype beïnvloed. Bij blankvleeskalveren waren dieren gehuisvest op Easyfix en ICE over het algemeen vuiler op het vleeskalverbedrijf, maar de gemiddelde bevuilingsscores bij blanke kalveren waren over het algemeen op alle vloeren lager dan de gemiddelde bevuilingsscores van rosékalveren. Bij rosékalveren was de bevuiling van kalveren op de Easyfix vloer over het algemeen vergelijkbaar met die van kalveren op betonnen roosters, terwijl de bevuiling van kalveren op ICE in vergelijking met die van dieren op de referentievloer significant lager was. Op het slachthuis werden enkele groepen kalveren op het slachthuis als vuil beoordeeld, waarbij individuele groepen zowel van alternatieve vloeren als van referentievloeren afkomstig waren.

Vloertype had geen effect op het karkasgewicht, de voeropname en de voerefficiëntie. De gemiddelde ammoniakuitstoot op de ICE en Easyfix vloer verschilde niet van die op referentievloer. Vloertype had ook geen effect op de geuremissie. De betonnen roostervloer had de hoogste stroefheid op basis van de instrumentele stroefheidsmetingen, de ICE en Easyfix vloer gemiddeld een tussenliggende stroefheid, en de houten roostervloer de laagste stroefheid. Deze bevindingen liggen niet helemaal in lijn met wat de kalverhouders zelf ervaren. Zij vinden het houten rooster niet gladder dan de alternatieve vloeren. Mogelijk speelt de smalle balkbreedte van de hardhouten roosters hierbij een rol. De meerkosten van de ICE en Easyfix vloer bedragen 5 - 10 Eurocent per kg geproduceerd vlees en ingeval de ondervloer ook vervangen moet worden 11 - 15 Eurocent. Op bedrijfsniveau stijgen de jaarkosten gemiddeld met enkele tienduizenden euro's.

De bevindingen tonen aan dat kalveren op alternatieve vloeren meer comfort ervaren dan op de referentievloeren; dit kan als een welzijnsverbetering worden beschouwd. 


\section{Summary}

The research into alternative floors for veal calves comprised of two parts: (i) a preliminary study, and (ii) a large scale study in practice. In the preliminary study five alternative floor types were examined in white veal (concrete slats, ICE, Easyfix, Van Beek rubber on concrete, Van Beek rubber on wood), and six alternative floor types were examined in pink veal (wooden slats, ICE, Easyfix, Van Beek rubber on concrete, Van der Velden Beton, and Kraiburg). The preliminary study was performed on four veal farms in practice, two white veal farms, and two pink veal farms. The preliminary study looked at lying comfort based on a choice experiment, and the effects of floor type on behaviour and health of veal calves. In the choice experiment, modified group pens were used; half of the floor of each pen was equipped with the reference floor type (i.e. concrete slats for pink veal calves, and wooden slats for white veal calves), and the other half was equipped with an alternative floor type. At two ages the times spent lying during 24-hours on each floor type (reference versus alternative) by calves in modified pens were recorded. For the assessment of the effect of floor type on behaviour and health of veal calves, pens were used with the entire floor consisting of either the reference floor or an alternative floor type; 12 pens per floor. The preliminary study also involved an initial experiment into the effect of floor type on ammonia emission. Both white and pink veal calves preferred to lie on relatively soft floor types. In comparison with the reference floor, the frequency of slipping behaviour was lower on ICE and Easyfix in white veal calves, and lower on Easyfix in pink veal calves. In white veal calves, the prevalence of carpal bursitis ("thick knees") was lower on ICE and Easyfix compared to the reference floor. The initial experiment on ammonia emission revealed no effects of floor type. Based on the overall results of the preliminary study, it was concluded that out of the alternative floors that were examined, ICE and Easyfix seemed to improve veal calf welfare, and should be subsequently studied in the large scale study in practice.

The large scale study in practice was considered the "litmus test" of the project, the results of which would allow to draw conclusions on the effects of alternative floor types on welfare and (technical) performance of veal calves under practical husbandry conditions. A total of 14 veal farms, 6 pink and 8 white, took part in the study. On each farm, three entire compartments - i.e., physically separated barns or compartments within a barn, each containing between 40 and approximately 200 group pens - were available. Within each farm, three floor types - i.e. reference, ICE or Easyfix - were randomly allocated to the three barns or compartments; subsequently all pens within a barn or compartment were equipped with the same floor type. Observations were performed during four successive batches (fattening cycles) on white veal farms, and during five successive batches on pink veal farms.

Observations included calf behaviour, in particular slipping, health, in particular regarding joints, cleanliness (both in detail at the level of the individual calf at the farm, and group-wise upon arrival at the slaughterhouse at the end of the fattening period, from a the perspective of hygiene during the subsequent slaughter process), use of antibiotics, the pathological condition of lungs after slaughter, feed intake, and slaughterweight. On two selected veal farms research into emission of ammonia and odour was performed according to a case-control design. In addition, on one white and one pink veal farm, dynamic surface roughness tests were conducted on reference floors as well as alternative floor types. Finally, an economic evaluation was conducted. In white veal calves, two weeks before slaughter the likelihood of slipping behaviour was lower on ICE and Easyfix compared to the reference floor. In both white and pink veal the prevalence of carpal bursitis was significantly lower among calves housed on ICE or Easyfix in comparison with animals housed on the reference floor. There were no differences between floors in any other clinical parameter. Lameness and claw or joint lesions were rarely seen in this study. The type of floor did not affect the use of antibiotics or mortality. Similarly, the prevalence of lung lesions recorded post mortem was not influenced by the type of floor. White veal calves kept on ICE or Easyfix were generally less clean than animals kept on the reference floor. Overall, white veal calves were cleaner than pink veal calves. Cleanliness of pink veal calves on Easyfix was similar to cleanliness of those on the reference floor, whereas pink veal calves housed on ICE were cleaner than those housed on the reference floor. At the slaughterhouse, some groups of 
white and pink veal calves were labelled as "dirty"; these groups, however, originated from the reference floors as well as the alternative floor types. Floor type did not affect slaughterweight, feed intake and feed efficiency. There were no differences between the reference floor and the alternative floor types in emission of ammonia or odour. As assessed by instrumental tests, on average the roughness of a concrete slatted floor was highest, the roughness of ICE and Easyfix was intermediate, and the roughness of a wooden slatted floor was lowest. These findings were not fully consistent with experiences reported by the veal farmers. They did not report a difference in roughness between the wooden slatted floor and the alternative floor types. Perhaps the smaller width of wooden slats plays a role here. Additional costs of ICE and Easyfix floors amount to 5 - 10 Eurocent per $\mathrm{kg}$ meat produced, and 11 - 15 Eurocent when the subfloor has to be replaced. At farm level, yearly costs will increase on average by several tens of thousands of euros.

The present findings demonstrate that calves are more comfortable on the alternative floor types than on the reference floors; this could be considered an animal welfare improvement. 


\section{$1 \quad$ Inleiding}

Het onderzoek naar alternatieven vloeren voor vleeskalveren vindt zijn oorsprong in het voornemen tot het verplicht stellen van rubber matten door de voormalig minister van LNV (vanaf 2009) in stallen waar vleeskalveren anders dan op stro worden gehuisvest (Nota Dierenwelzijn, 2007). De minister geeft aan dat met de huidige groepshuisvesting een grote stap voorwaarts is gezet in de verbetering van het welzijn echter binnen dit houderijsysteem wil de minister zoeken naar een oplossing voor de gladde en harde vloeren. Deze verplichtstelling was voor de Tweede Kamer aanleiding een motie in te dienen. In de aangenomen motie van Van der Vlies c.s. (begin 2008) werd gepleit voor het opschorten van de verplichtstelling en verzocht in een grootschalig praktijkonderzoek alternatieve vloeren te vergelijken op de effecten op o.a. loop- en ligcomfort, diergezondheid en stalklimaat. Op basis van de onderzoeksresultaten zal een besluit worden genomen over mogelijke regelgeving waarin bepaalde vloertypen voorgeschreven kunnen worden.

De motivatie om voor onderzoek te pleiten was dat de gerapporteerde effecten van vloertypen, inclusief rubber matten, op het welzijn van vleeskalveren niet eenduidig zijn en het onderzoek naar alternatieve vloeren bij vleeskalveren vooralsnog oriënterend en kleinschalig van karakter was. Daarnaast betekent verplichtstelling van alternatieve vloeren een forse investering voor de vleeskalverhouders, een zorgvuldige afweging van de vloeren is dan ook gewenst. In opdracht van destijds het ministerie LNV is door Wageningen UR Livestock Research samen met vertegenwoordigers uit de vleeskalversector en de Dierenbescherming een onderzoeksvoorstel geschreven wat een duidelijk antwoord moest geven op de vraag of een alternatieve vloer in vergelijking met het huidige vloertype (referentie), beter is voor het welzijn van het kalf (loop- en ligcomfort). Daarnaast moet het onderzoek inzicht geven in de effecten van alternatieve vloeren op emissie, stalklimaat en de invloed daarvan op de gezondheid van het kalf en technische prestaties.

In de Nota Dierenwelzijn werd aangegeven dat de overheid binnen het huidige, reguliere huisvestingssysteem zoekt naar een oplossing voor gladde vloeren. Daarmee richt het onderzoek zich op welzijnsvriendelijke alternatieven voor de huidige roostervloer. Met dit uitgangspunt realiseert de project- en stuurgroep zich dat dit de mogelijkheid beperkt om nieuwe huisvestingsconcepten te ontwikkelen. Ook betekent dit dat strosystemen geen deel uit zullen maken van het onderzoek omdat dit een heel ander houderijconcept vraagt. Dit is in lijn met de door LNV geformuleerde opdracht op zoek te gaan naar alternatieve vloeren in stallen waar vleeskalveren anders dan op stro worden gehuisvest. De Dierenbescherming tekent hierbij aan dat zij het achterwege laten van een strosysteem binnen het onderzoeksproject nog steeds een gemiste kans vindt.

Het onderzoek is begin 2009 gestart en eind 2016 afgerond. Deze relatief lange looptijd heeft twee belangrijke redenen (i) omdat alternatieve vloertypen voor vleeskalveren ten tijde van het aannemen van de motie van der Vlies (2008) nog nauwelijks beschikbaar waren is voorafgaand aan een grootschalige praktijkproef eerst een voorstudie uitgevoerd waarin nieuwe vloerconcepten door geïnteresseerde bedrijven zijn ontwikkeld en op een beperkt aantal vleeskalverbedrijven zijn beproefd, en (ii) deelname van vleeskalverhouders aan de grootschalige praktijkproef was vrijwillig; Ruim 50 vleeskalverbedrijven toonden belangstelling voor deelname, ca 40 meldden zich officieel aan. Hiervan konden er 14 voldoen aan de onderzoeksvereisten voor deelname : 8 blankvleesbedrijven en 6 rosébedrijven. Op al deze bedrijven zijn twee (en op de blankvleesbedrijven drie) afdelingen eerst voorzien van nieuwe vloeren. Het aantal van 14 deelnemende bedrijven was op zichzelf een acceptabel aantal, maar om tot voldoende waarnemingen te komen was het nodig om op elk van 8 blankvleesbedrijven in totaal vier, en op elk van de 6 rosébedrijven in totaal vijf opeenvolgende mestronden te draaien. Bij blankvleeskalveren had het onderzoek betrekking op de volledige mestperiode. Bij rosékalveren is het onderzoek uitgevoerd tijdens de afmestfase. Het project is gefinancierd door de overheid (ministerie LNV en EZ) en het Productschap Vee en Vlees. 


\section{Toelichting volledige onderzoekstraject}

Het onderzoeksproject bestond uit twee fasen (studies). De eerste fase (voorstudie) was een verkennende studie met de nadruk op het lig- en loopcomfort. Op basis van deze studie is een keuze gemaakt voor de vloeren in fase 2 , het grootschalige praktijkonderzoek. Deze praktijkstudie is de 'lakmoesproef' en sluitstuk van het onderzoek. Een op basis van de uitkomsten van het onderzoek geschikt bevonden vloertype zal worden beschreven in termen van technische en anderszins relevante karakteristieken, en niet in termen van een specifiek merk.

Voor het selecteren van de te testen vloeren in de voorstudie zijn allereerst oriënterende gesprekken gevoerd met fabrikanten, c.q. leveranciers van alternatieve vloeren. Vervolgens hebben zeven bedrijven hun vloeren gepresenteerd, deze zijn meegenomen in de verdere selectieprocedure. Voor de selectie van de vloeren zijn beoordelingscriteria opgesteld en uitgewerkt in een Programma van Eisen. Daarbij is als vertrekpunt genomen de eisen vanuit het kalf. Dit waren dierenwelzijn (klauwgezondheid, ligcomfort, gewrichten en beloopbaarheid), hygiëne (bevuiling kalf, bezoedeling karkas) en emissie (gezonder stalklimaat). De uitdaging was vervolgens dit Programma van Eisen te vertalen naar eisen voor de vloeren zoals stroefheid, mate van indrukbaarheid, voldoende ondersteunend vloeroppervlak, mestdoorlaatbaarheid en reinigbaarheid. Daarnaast was de beschikbaarheid van de vloer op korte termijn een selectiecriterium. Het was nadrukkelijk de verantwoordelijkheid/uitdaging van de fabrikant om met een vloertype te komen dat aansluit bij het Programma van Eisen. De vloeren zijn beoordeeld voor geschiktheid in de rosé en blanke vleeskalverhouderij.

Deze voorfase heeft geresulteerd in de keuze van de onderzochte vloeren in de voorstudie. Op basis van de resultaten van de voorstudie is in een afwegingsproces de keuze gemaakt voor de te onderzoeken vloeren in het praktijkonderzoek. 


\section{Voorstudie}

\subsection{Materiaal en Methode}

\subsubsection{Proefopzet}

Het onderzoek bestond uit een tweetal studies: (i) een studie specifiek naar ligcomfort, en (ii) een studie naar de effecten van vloertype op gedrag, bevuiling en de gezondheidstoestand van klauwen en gewrichten. De experimentele eenheid bij deze studies is "hok". Elke studie is uitgevoerd bij zowel blankvlees- als rosékalveren. Het onderzoek bij rosékalveren had uitsluitend betrekking op de afmestfase, d.w.z. de periode vanaf ca. 12 weken na opzetten tot het einde van de mestperiode. Voorafgaan aan de afmestperiode werden rosékalveren als zogenaamde "starters" gehouden, in hokken met een houten lattenbodem.

Het onderzoek werd uitgevoerd op in totaal 4 bedrijven: 2 blankvleesbedrijven en 2 rosébedrijven. De benodigde hokken voor de studie naar effecten van vloertype op dierkenmerken werden bij zowel blankvlees- als rosékalveren verdeeld over de beschikbare bedrijven. De studie naar ligcomfort van blankvleeskalveren werd eveneens op de twee beschikbare blankvleesbedrijven uitgevoerd. De studie naar ligcomfort bij rosékalveren werd, door praktische onuitvoerbaarheid, op één van de twee rosébedrijven uitgevoerd.

Uit oogpunt van efficiëntie werd slechts de helft van het totale aantal benodigde hokken uitgevoerd met het gewenste vloertype. Vervolgens zijn kalveren uit twee opeenvolgende mestrondes bestudeerd, waarbij elk experimenteel hok twee keer werd gebruikt. Zodoende was het totale aantal experimentele eenheden (herhalingen) twee keer zo groot als het aantal hokken. Bestudering van kalveren uit twee opeenvolgende mestrondes zorgde er bovendien voor dat er sprake was van een zinvolle variatie in seizoensinvloeden tijdens het onderzoek.

Bij blankvleeskalveren bestond de controlevloer (referentie) uit een houten lattenbodem, en werden vervolgens 5 alternatieven - beton plus 4 nieuwe varianten - met de controlevloer vergeleken. Bij rosékalveren bestond de controlevloer uit betonnen roosters, en werden 6 alternatieven - hout plus 5 nieuwe varianten - met de controlevloer vergeleken. In Tabel 1 staan de vloertypen onder elkaar die zijn onderzocht bij, respectievelijk, blankvlees- en rosékalveren. Voor een deel werden dezelfde vloertypen bij zowel blankvlees- als rosékalveren onderzocht.

Tabel 1. Vloertypen die zijn onderzocht bij blankvlees- en rosékalveren.

\begin{tabular}{lll} 
Vloer & Blankvlees & Type houderij \\
\hline Controle (referentie) & Hout & Rosé \\
\hline Alternatief 1 & Beton & Beton \\
\hline Alternatief 2 & ICE & ICE \\
\hline Alternatief 3 & Easyfix & Easyfix \\
\hline Alternatief 4 & Van Beek Rubber op beton & Van Beek rubber op beton \\
\hline Alternatief 5 & Van Beek Rubber op hout & Van der Velden Beton \\
\hline Alternatief 6 & & Kraiburg \\
\hline
\end{tabular}

* Foto's en beschrijving van de vloeren zijn terug te vinden in de bijlage 3

\subsubsection{Studie naar ligcomfort}

Binnen hetzelfde hok werd de helft van het vloeroppervlak voorzien van een controlevloer (de reguliere houten lattenbodem bij blankvleeskalveren, betonnen roostervloer bij rosékalveren), en de andere helft van een alternatief vloertype. Vervolgens werd gekeken naar de voorkeur van vleeskalveren om liggedrag op het ene of het andere vloertype uit te voeren. De belangrijkste uitleesparameter is - per gedrag - de tijd doorgebracht op een bepaald vloertype. De onderliggende 
gedachte was dat een voorkeur voor een bepaald vloertype om op te liggen in belangrijke mate samenhangt met een verhoogd ligcomfort zoals dat door het kalf zelf wordt ervaren.

Elk experimenteel hok waarvan een gedeelte van de vloer was voorzien van een bepaald alternatief vloertype, werd op twee manieren uitgevoerd. Schematisch kan dat als volgt worden weergegeven (zie figuur 1).

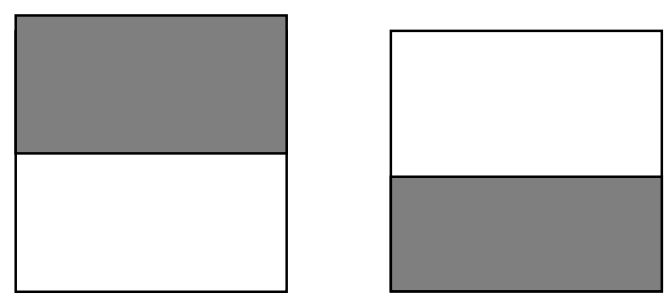

Figuur 1. Schematische weergave van de lay-out van de vloer van hokken die gebruikt worden in de studie naar ligcomfort. De donkergekleurde oppervlakten stellen het alternatieve vloertype voor, en de witte oppervlakten de controlevloer.

In de schematische weergave van een hok in figuur 1 bevindt het voerhek zich evenwijdig aan de lange zijde van de donkergekleurde rechthoek. Door toepassing van deze opzet werd gecontroleerd voor positie-effecten op de voorkeur van kalveren. Elk alternatief vloertype werd in veelvouden van de bovenstaande twee hokken opgezet. Bij blankvleeskalveren bestond de controlevloer uit een houten lattenbodem, en werden vervolgens 5 alternatieven binnen hokken met de controle vergeleken. Bij rosékalveren bestond de controlevloer uit betonnen roosters, en werden 6 alternatieven binnen hokken met de controle vergeleken. Voor elke vergelijking werden 10 herhalingen gebruikt ( 5 keer een tweetal hokken zoals hierboven schematisch aangegeven). Het totale aantal herhalingen kwam daarmee op 110 stuks, 50 voor blankvleeskalveren (10 per vergelijking) en 60 voor rosékalveren (eveneens 10 per vergelijking).

Gedragswaarnemingen werden uitgevoerd met behulp van video-opnames. Van de kalveren in elk experimenteel hok (waarin twee vloertypen aanwezig waren) werd op twee momenten gedurende een volledig etmaal (24 uur) het gedrag op video vastgelegd in "time-lapse" (d.w.z. versneld). De verzamelde opnames werden uitgelezen op (i) het activiteitenpatroon over de dag (staan en liggen), en (ii) de plaats waar de kalveren zich bevinden (op de controlevloer of op de alternatieve vloer). Bij het liggedrag werd ook de lighouding meegenomen. Bij blankvleeskalveren werden deze waarnemingen gedaan op 10 weken na opzetten, en 2 weken voor het slachten. Bij rosékalveren werden deze waarnemingen gedaan 4 weken na aanvang van de afmestperiode en 2 weken voor het slachten.

In elk hok bestemd voor het onderzoek naar ligcomfort werden slechts de helft van het reguliere aantal dieren opgezet. Hierdoor vond er geen competitie plaats voor ligruimte, en konden alle kalveren in een hok, wanneer zij dat wilden, tegelijkertijd dezelfde voorkeur voor een bepaald vloertype laten zien.

\subsubsection{Studie naar effect van vloertype op dierkenmerken}

Deze studie werd gelijktijdig uitgevoerd met de studie naar ligcomfort. Per type houderij (blankvlees versus rosé), per vloertype werden 12 hokken gebruikt. In deze studie werd van elk hok de gehele vloer met het betreffende vloertype uitgerust. In dit onderdeel van het onderzoek werden dezelfde alternatieve vloertypen als in de studie naar ligcomfort gebruikt. Het totaal aantal experimentele behandelingen kwam daarmee voor blankvleeskalveren op 6 (één controlevloer, hout, en 5 alternatieve vloertypen) en voor rosékalveren op 7 (één controlevloer, beton, en 6 alternatieve vloertypen). Het aantal benodigde hokken voor blankvlees- en rosékalveren bedroeg, respectievelijk, 72 en 84.

Waarnemingen aan het dier vallen in de volgende onderdelen uiteen: (a) gedrag, (b) klinische gezondheid, (c) pathologie (post mortem onderzoek), (d) bevuiling, en (e) technische resultaten. 


\section{(a) Gedrag}

Gedragswaarnemingen waren primair gericht op het registreren van de incidentie van uitglijden, en werden uitgevoerd met behulp van video-opnames. Op twee leeftijden (dezelfde twee leeftijden als in de studie naar ligcomfort) werd gedurende een periode van 4 uur rond één van de voerbeurten (kalvermelk bij blankvleeskalveren, ruwvoer bij rosékalveren) het gedrag op video vastgelegd, in "real time". Later werden de verzamelde opnames uitgelezen op het vóórkomen van uitglijden, en worden het gaan staan en gaan liggen gekarakteriseerd. Naast de frequentie van uitglijden, zijn ook de frequenties waargenomen van: (i) vechten, (ii) dartelen (spelgedrag), en (iii) bespringen.

\section{(b) Gezondheid}

Een belangrijk aspect van de klinische gezondheid in de context van het vloerenonderzoek is de gezondheidstoestand van klauwen en gewrichten, en het vóórkomen van kreupelheid. De klinische gezondheid wordt beoordeeld door ervaren vleeskalverdierenartsen, conform het protocol klinische gezondheid zoals dat ten behoeve van de welzijnsmonitor is ontwikkeld. Bijzondere aandacht ging uit naar de volgende twee verschijnselen: (1) kreupelheid (licht respectievelijk ernstig), en (2) de aanwezigheid van "verkregen slijmbeurs" ook wel "dikke knieën" genaamd, een doorgaans niet pijnlijke verdikking van de knieën (door ophoping van vocht) die het gevolg is van (overmatige) wrijving en frictie.

\section{(c) Pathologie}

Aan de hand van waarnemingen aan het dode dier (post mortem) werd de pathologische toestand van klauwen en gewrichten na slachting beoordeeld onder supervisie van een veterinair-patholoog. Van elk kalf dat bij het onderzoek betrokken was, zijn tenminste drie poten (en bijbehorende kniegewrichten) op pathologische afwijkingen beoordeeld. Speciale aandacht ging uit naar: (1) beschadigingen aan klauw en de huid rond de klauw, (2) de lengte van de klauw, en (3) afwijkingen aan het carpaal gewricht.

\section{(d) Bevuiling}

Bevuiling werd parallel met de gedragswaarnemingen beoordeeld. Het lichaam van het kalf werd onderverdeeld in 14 lichaamsdelen. Bij elk individueel kalf werd de mate van bevuiling van elk van de 14 lichaamsdelen gescoord: de score per lichaamsdeel was 0 wanneer $<25 \%$ bevuild was met mest of delen van mest, en de score was 1 wanneer $>25 \%$ van het betreffende lichaamsdeel was bevuild. Bevuiling van de buik 2 weken voor het slachten is apart geanalyseerd (zie verder), vanuit de veronderstelling dat deze variabele representatief zou kunnen zijn voor het risico op bezoedeling van (delen van) het karkas na slachting.

(e) Technische resultaten

Blankvleeskalveren en rosékalveren zijn individueel gewogen, respectievelijk bij opzetten en bij aanvang van de afmestfase. Na slachting is van elk kalf karkasgewicht bepaald. Samen met het begingewicht kon hieruit de gemiddelde groei per dag worden afgeleid.

\subsubsection{Verkennende studie naar effect van vloertype op de ammoniakemissie}

Ook milieuaspecten zijn bij de integrale beoordeling van de vloeren van belang. De uitvoering van de loopvloer kan immers van invloed zijn op de emissies vanuit de stal. Dit is een belangrijk aspect bij de vergunningverlening. Om die reden zijn oriënterende ammoniakemissiemetingen opgenomen in het onderzoek.

De opzet van het onderzoek (met verschillende vloertypen in één ruimte) liet niet toe dat er volgens het officiële meetprotocol voor vaststelling van ammoniakemissies werd gemeten. Officiële emissiemetingen dienen op stal- of afdelingsniveau plaats te vinden. Als binnen één afdeling verschillende vloeren worden toegepast, is het niet mogelijk om via metingen op afdelingsniveau het effect te bepalen. Een methode die dan wel kan worden toegepast is de z.g. dynamische boxmethode, waarbij een Lindval-box over een te onderzoeken vloergedeelte wordt geplaatst. Met behulp van een ventilator wordt een luchtstroom door de box geleid, en de in- en uitgaande gasconcentraties worden gemeten. Omdat tijdens het uitvoeren van zo'n meting de vloer niet door dieren betreden en bevuild 
kan worden, wordt steeds gedurende een korte tijd (ca $1 / 2$ uur) gemeten. Daarna wordt de box verplaatst naar een ander hok in de afdeling (met een andere vloer), waar vervolgens een nieuwe meting wordt uitgevoerd. Op deze wijze worden kortstondige emissie metingen uitgevoerd die onderling met elkaar kunnen worden vergeleken. De methodiek is een goed indicatieve methode, maar niet geschikt om absolute en exacte emissieniveaus te bepalen.

De boxmetingen zijn uitgevoerd op 1 blankvlees- en 1 rosé-bedrijf. Deze bedrijven zijn in de periode september 2010 - april 2011 twee- respectievelijk driemaal bezocht, waarbij tijdens elk bezoek ieder vloertype tweemaal is bemeten.

Er is gebruik gemaakt van een meetbox met oppervlakte van $1 \mathrm{~m}^{2}$. De luchtstroom door de box bedroeg $200 \mathrm{~m}^{3} / \mathrm{h}$. Dit komt overeen met een (horizontale) luchtsnelheid over de vloer van ca $14 \mathrm{~cm}$ per seconde. De $\mathrm{NH}^{3}$-concentraties in de in- en uitgaande lucht van de meetbox werden continu geregistreerd met behulp van 2 multi-gasmonitoren (Type: Innova) en opgeslagen in een databestand.

Met behulp van het tracergas SF6 is nagegaan of er sprake was van duidelijke verschillen tussen de vloertypen in de mate waarin luchtuitwisseling plaatsvindt van onder en boven het rooster. De resultaten per meting zijn verwerkt en per vloertype berekend als ammoniakemissie per $\mathrm{m} 2$ vloeroppervlak per uur. Vervolgens zijn ze omgerekend en uitgedrukt als relatieve emissie ten opzichte van die van het referentievloertype (hardhout voor blankvlees en betonrooster voor rosé).

\subsubsection{Eindinspectie vloeren en ervaringen kalverhouders}

$\mathrm{Na}$ afloop van de proef zijn alle 4 deelnemende vleeskalverhouders bezocht en geënquêteerd naar hun ervaringen met de proefvloeren. Tevens zijn de vloeren aan een afsluitende visuele beoordeling onderworpen en zijn, waar dit praktisch en veilig mogelijk was, de maatvoeringen van de roosterbalken en spleetbreedtes op verschillende plaatsen in de stal steekproefsgewijs bepaald. Tijdens deze eindinspectie waren de afdelingen gewoon in gebruik. De vloeren zijn derhalve in "bevuilde" conditie beoordeeld.

\subsubsection{Statistische analyses}

Gegevens met betrekking tot gedrag, klinische gezondheid, pathologie en groei zijn geanalyseerd met behulp van variantieanalyse. In het statistische model waren de volgende factoren opgenomen:

(i) vloertype, (ii) ronde en (iii) bedrijf. Voor blankvlees- en rosékalveren zijn aparte analyses uitgevoerd. In principe was "hok" bij deze analyses de experimentele eenheid. Alle variabelen zijn daartoe eerst uitgedrukt op het niveau van het individuele hok.

In de ligcomfortproef is specifiek getoetst - met behulp van Wilcoxon Matched Pairs Rank Test - of de tijd besteed aan liggen op de alternatieve vloer, uitgedrukt als \% van de totale tijd besteed aan liggen, significant afweek van 50\%. Wanneer de tijd besteed aan liggen (als \% van de totale tijd besteed aan liggen) significant hoger is dan $50 \%$, dan is sprake van een voorkeur.

Uitglijden, vechten, dartelen en bespringen zijn uitgedrukt als frequenties per hok, en als zodanig statistisch geanalyseerd. Daarnaast is het aantal keren uitglijden per hok ook uitgedrukt als percentage van de som van het aantal keren uitglijden, het aantal keren vechten, het aantal keren dartelen, en het aantal keren bespringen. Dit percentage is een maat voor de waarschijnlijkheid dat activiteit (i.c. vechten, dartelen, en bespringen) gepaard gaat met uitglijden. Hoe lager dit percentage, hoe kleiner deze waarschijnlijkheid. Op de aldus verkregen aantallen en percentages is variantieanalyse toegepast.

Klinische afwijkingen zijn gescoord op het niveau van het individuele kalf ( $0=$ niet afwijkend, $1=$ wel afwijkend), en uitgedrukt als \% per hok. Pathologische afwijkingen zijn gescoord op het niveau van de individuele poot, c.q. het individuele gewricht ( $0=$ niet afwijkend, $1=$ wel afwijkend), en eveneens uitgedrukt als \% per hok. Deze percentages zijn onderworpen aan variantieanalyse.

Op het niveau van het individuele kalf is, als kwantitatieve maat voor de totale bevuiling, het aantal bevuilde lichaamsdelen uitgedrukt als \% van het totaal aantal gescoorde lichaamsdelen (i.c. 14). Voor dit percentage zijn vervolgens hokgemiddelden berekend. Er is apart gekeken naar bevuiling van de buik (één van de 14 lichaamsdelen). Op het niveau van het individuele kalf werd bevuiling van de buik 
uitgedrukt in de score 0 (geen bevuiling) of 1 (wèl bevuiling van de buik). Per hok werd vervolgens het \% kalveren met score 1 berekend, en geanalyseerd met variantieanalyse.

Wanneer het gemiddelde \% voor een hele vloer, ronde, of bedrijf de waarde 0 had, kon geen gebruik gemaakt worden van variantieanalyse. In statistische termen "convergeerde" het statistische model dan niet. In dié gevallen werd gebruik gemaakt van een zogenaamde exacte toets - Fisher's exact test - waarbij paarsgewijs percentages met elkaar worden vergeleken (bijvoorbeeld het \% kalveren met een bevuilde buik gehuisvest op een alternatief vloertype met het \% kalveren met een bevuilde buik gehuisvest op de referentievloer). De uitkomst van deze toets is valide, met dien verstande dat geen rekening wordt gehouden met hokken, rondes, en bedrijven. Fisher's exact test is gebruikt voor de analyse van: (i) verkregen slijmbeurs, (ii) bevuiling van de buik, (iii) afwijkingen aan het carpaal gewricht, en (iv) lange klauwen.

\subsection{Resultaten}

\subsubsection{Studie naar ligcomfort}

\subsubsection{Blankvleeskalveren}

Blankvleeskalveren lieten, voor wat betreft hun liggedrag, een duidelijke voorkeur zien ten opzichte van de referentievloer wanneer de alternatieve vloer voorzien was van een zachte bovenlaag (i.c., ICE, Easyfix, van Beek rubber op hout, en van Beek rubber op beton). Voor beton bestond ten opzichte van hout geen voorkeur (zie figuur 2).

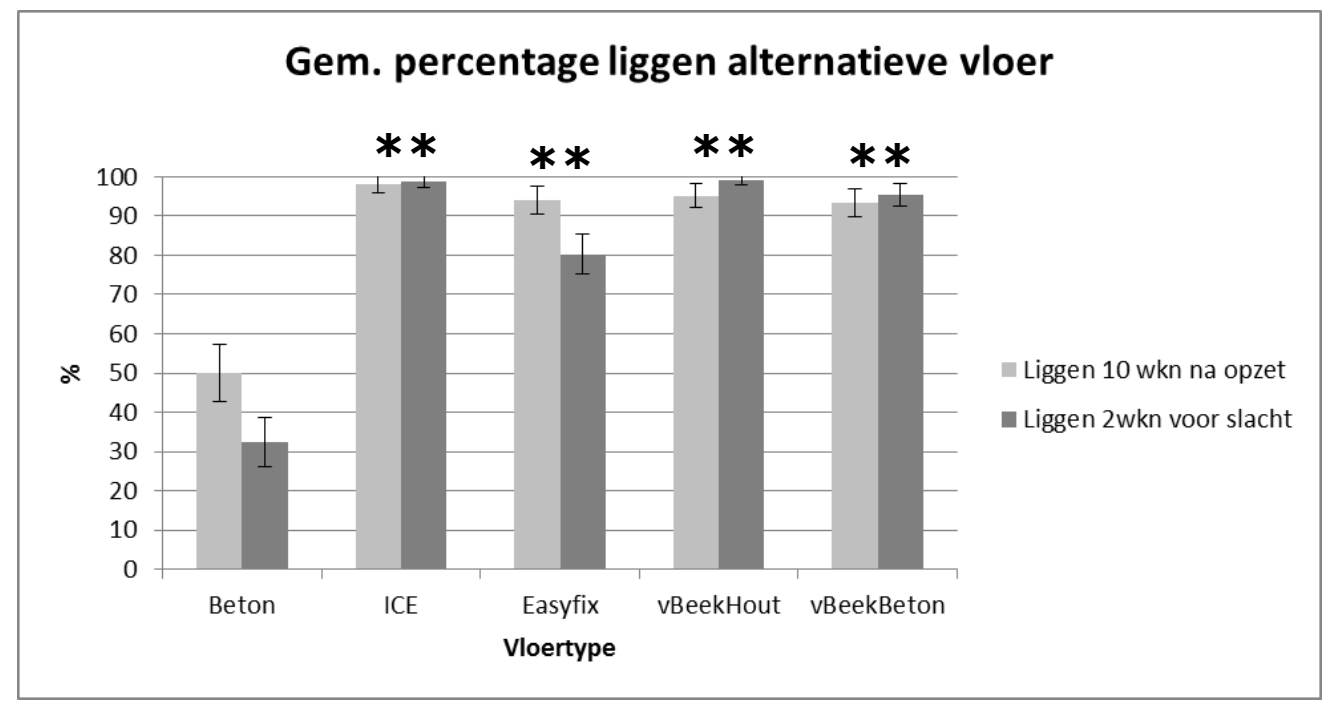

Figuur 2. Percentage liggen op alternatieve vloer van de totale ligtijd (gedurende 24 uur).

\subsubsection{Rosé kalveren}

Twee weken voor het slachten lagen rosékalveren liever op ICE of op van Beek rubber op beton, dan op de betonnen referentievloer (figuur 3). Voor Easyfix benaderde deze voorkeur statistische significantie $(P<0.10)$. 


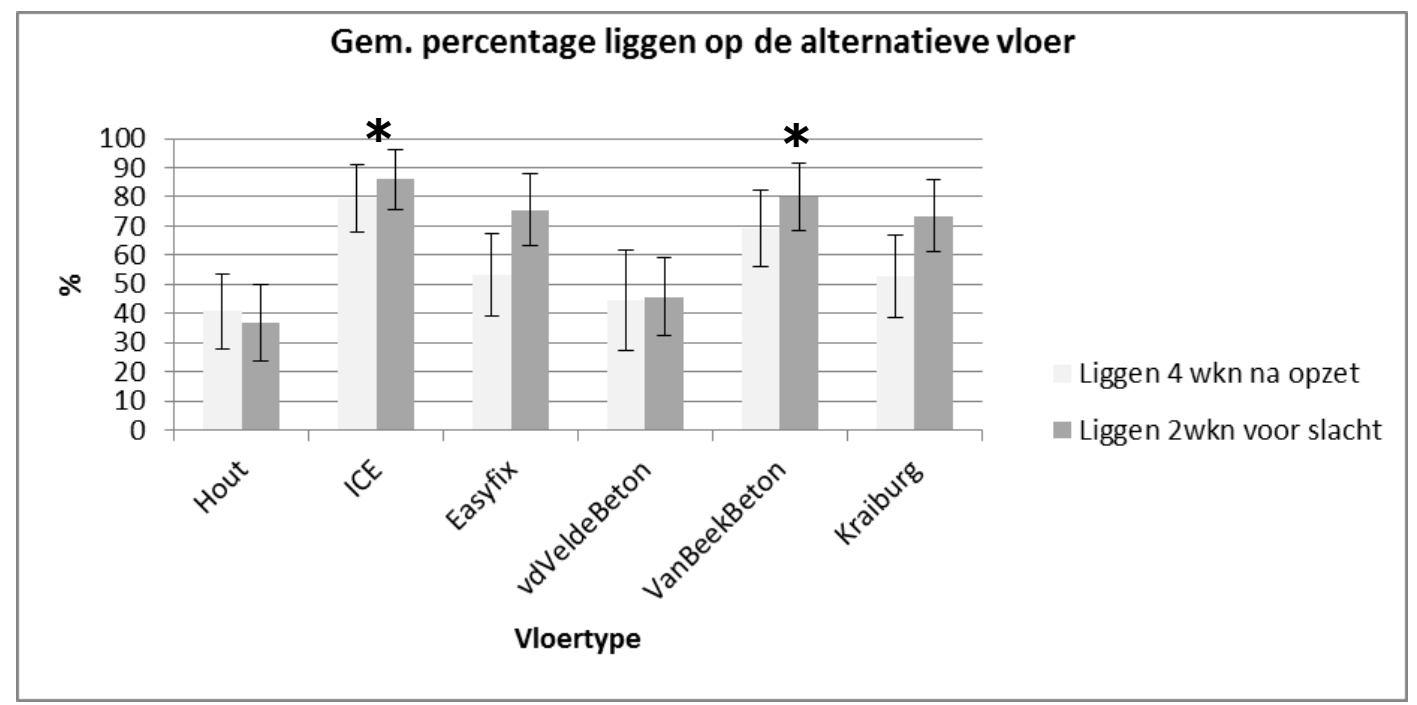

Figuur 3. Percentage liggen op alternatieve vloer van de totale ligtijd (gedurende 24 uur).

\subsubsection{Studie naar effect van vloertype op dierkenmerken}

\subsubsection{Blankveeskalveren}

Uitglijden

Op beton en op Easyfix was het gemiddeld aantal keer uitglijden significant lager ten opzichte van hout (figuur 4). De waarschijnlijkheid dat activiteit gepaard gaat met uitglijden was ten opzichte van de referentievloer significant lager op Easyfix, Beton en ICE (zie figuur 5).

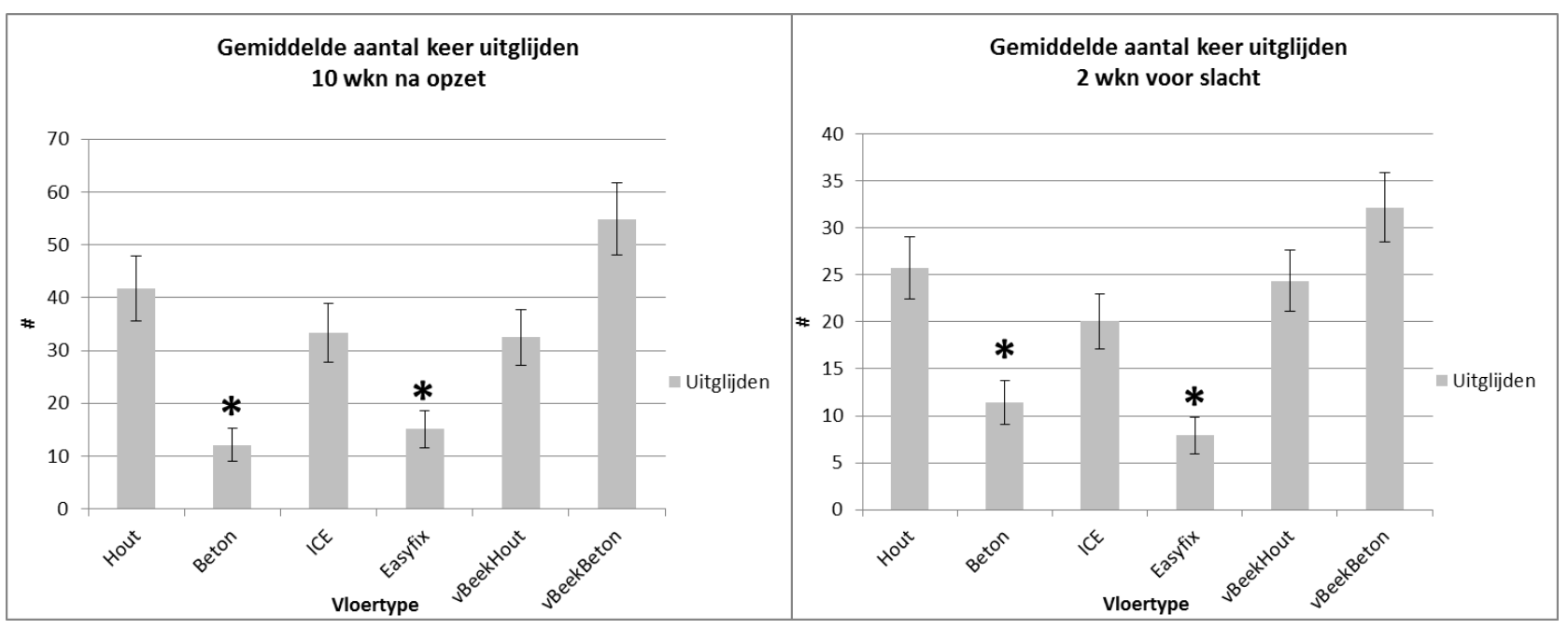

Figuur 4. Gemiddeld aantal keer uitglijden op 10 weken na opzet en 2 weken voor slacht. 

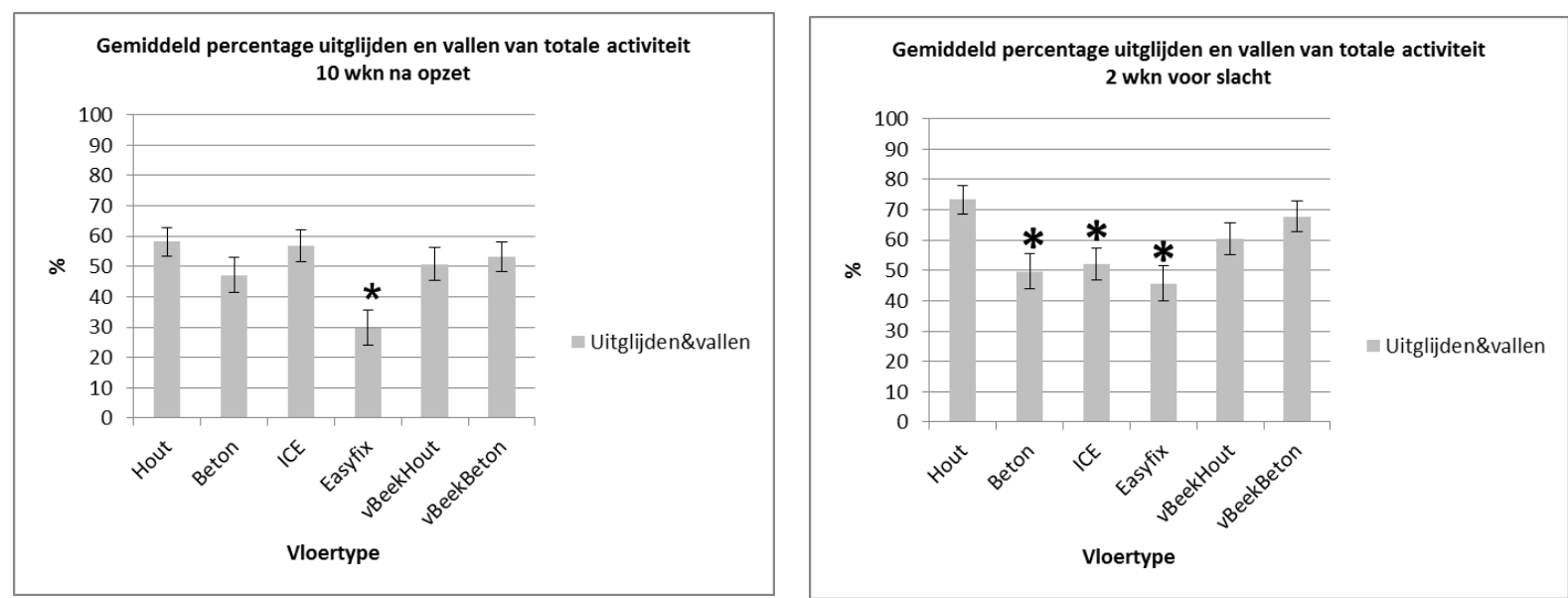

Figuur 5. Gemiddeld percentage uitglijden en vallen ten opzichte van de totale activiteit 10 weken na opzet en 2 weken voor slacht.

\section{Klinische variabelen}

De prevalentie (licht of ernstig) kreupele kalveren was over het algemeen laag ( $<3 \%$ op alle vloeren), en er waren geen significante verschillen tussen de referentie en alternatieve vloertypen. Twee weken vóór het slachten lieten kalveren op ICE en Easyfix een significant lagere prevalentie "verkregen slijmbeurs" zien ten opzichte van de referentie (figuur 6 ).

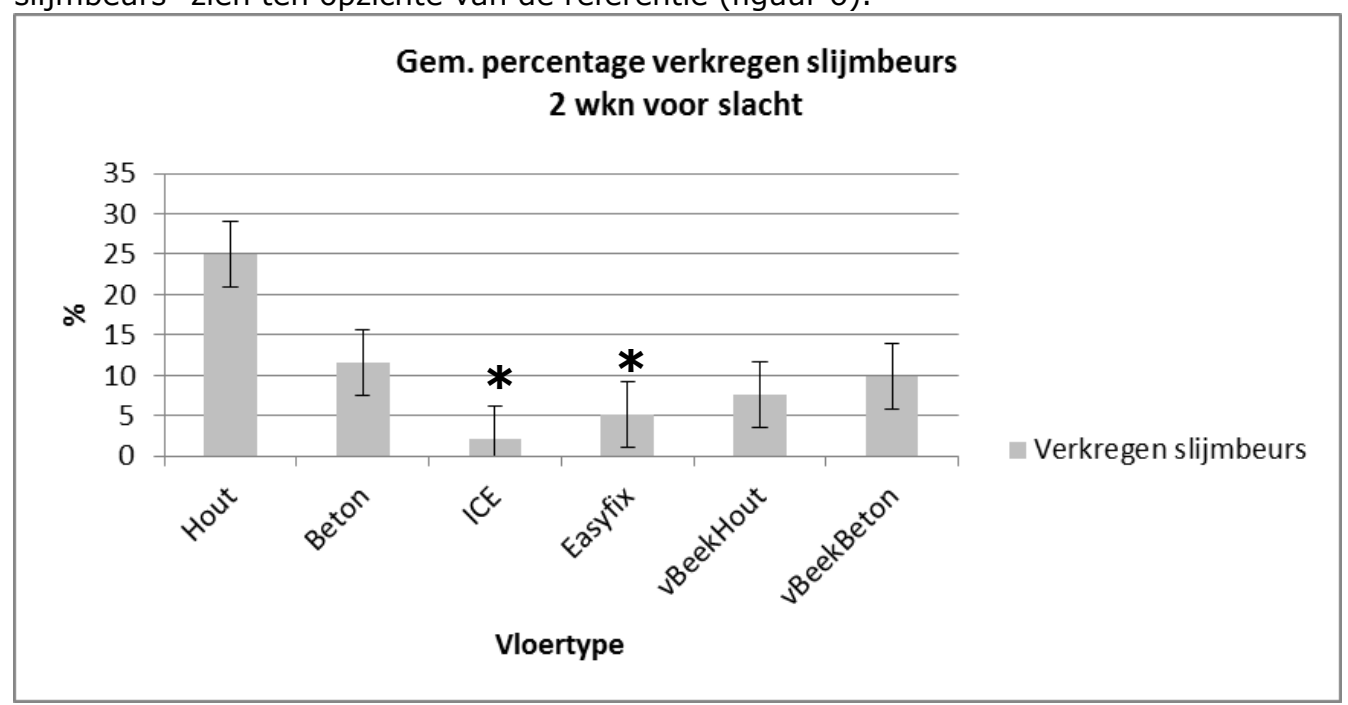

Figuur 6. Gemiddeld percentage verkregen slijmbeurs 2 weken voor slacht.

\section{Pathologische variabelen}

Prevalenties van beschadigingen aan klauw en huid rond de klauw verschilden niet tussen de referentievloer enerzijds en alternatieve vloertypen anderzijds. Het percentage kalveren met relatief lange klauwen nam ten opzichte van de referentievloer toe op met name ICE. Voor wat betreft het percentage kalveren met pathologische afwijkingen aan het karpaalgewricht van de rechter- en/of linker voorpoot, waren er geen significante verschillen tussen de referentievloer en de alternatieve vloertypen. Het verschil tussen de houten vloer en ICE tendeerde naar significantie $(P<0.10)$.

\section{Bevuiling}

Twee weken voor het slachten waren kalveren op beton over het gehele lichaam gerekend meer bevuild dan kalveren op hout (figuur 7). Het percentage kalveren met een bevuilde buik was twee weken voor het slachten hoger op beton en Easyfix dan op hout (figuur 8). 

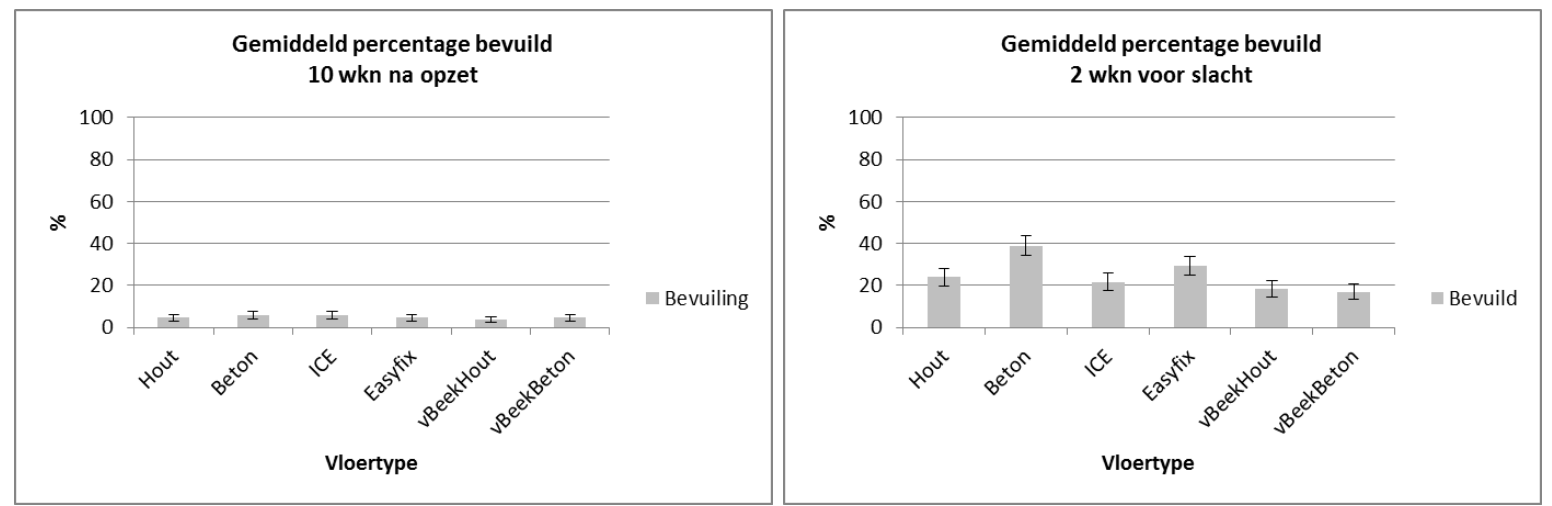

Figuur 7. Gemiddeld percentage van het kalf bevuild op 10 weken na opzet en 2 weken voor slacht.

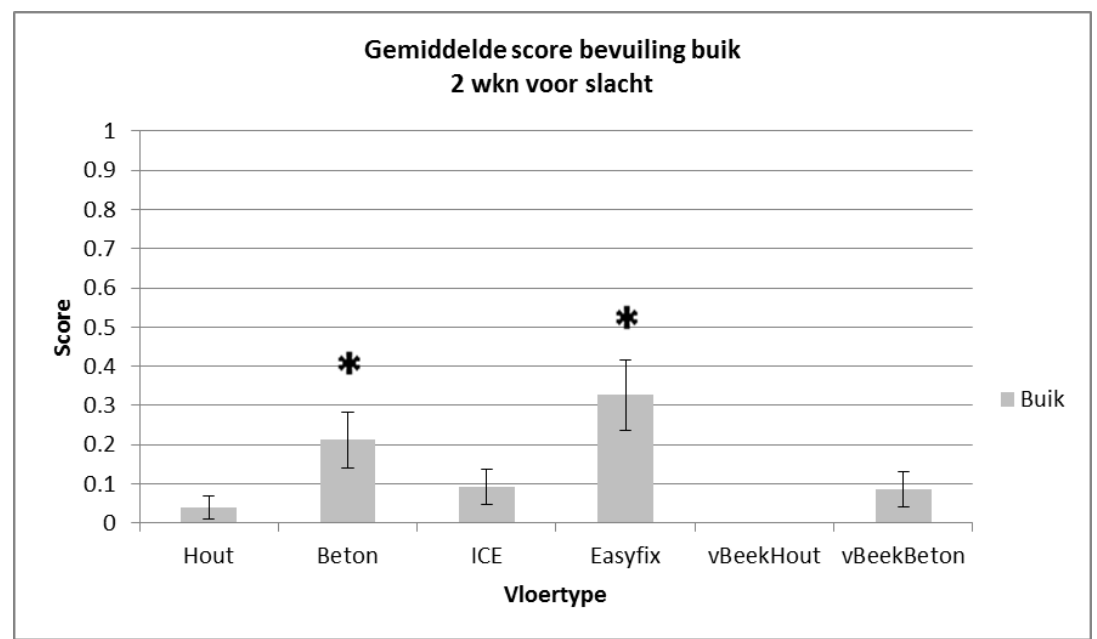

Figuur 8. Gemiddelde score voor bevuiling buik 2 weken voor slacht.

Groei

Blankvleeskalveren op verschillende vloertypen lieten een vergelijkbare gemiddelde groei zien.

\subsubsection{Rosékalveren}

\section{$\underline{\text { Uitglijden }}$}

Absoluut gezien was de frequentie van uitglijden van rosékalveren ten opzichte van de referentievloer het allerhoogst op van Beek rubber op beton (figuur 9). Verhoogde frequenties uitglijden werden ook gezien op ICE ( 4 weken na aanvang van de afmestperiode), en op hout (2 weken voor het slachten) (figuur 9). De waarschijnlijkheid dat activiteit gepaard gaat met uitglijden was ten opzichte van de referentievloer significant lager op van der Velden Beton (4 weken na aanvang van de afmestperiode) en op Easyfix ( 2 weken voor het slachten), en was significant hoger op hout (4 weken na aanvang van de afmestperiode) en op van Beek rubber op beton (beide leeftijden) (figuur 10).

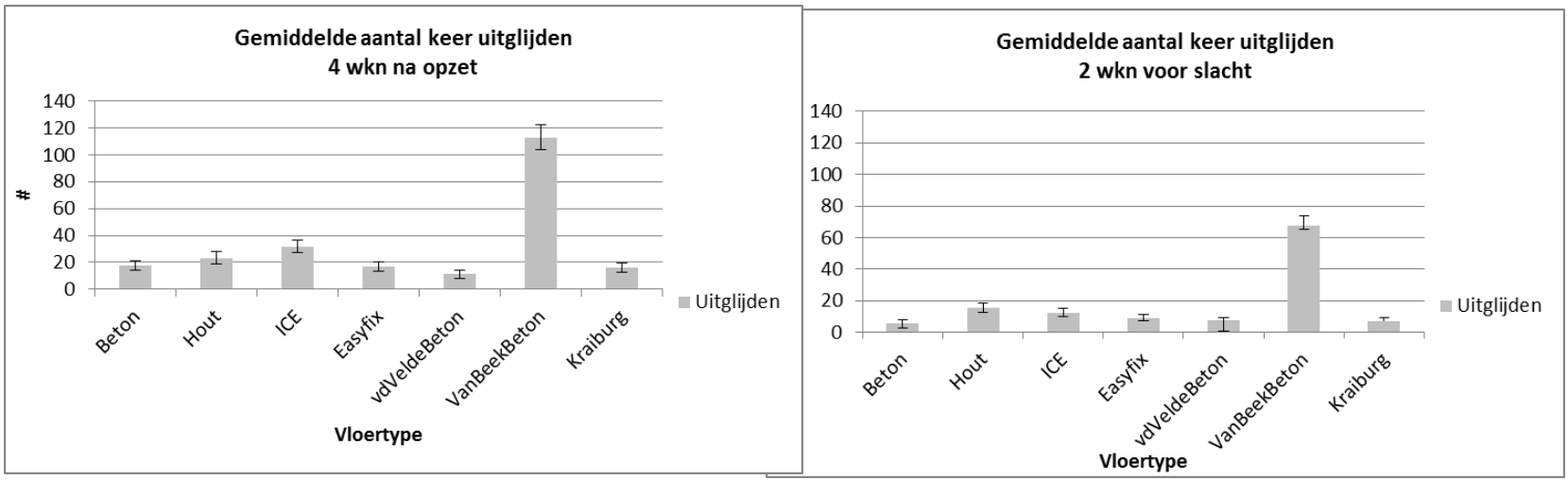

Figuur 9. Gemiddeld aantal keer uitglijden op 10 weken na opzet en 2 weken voor slacht. 


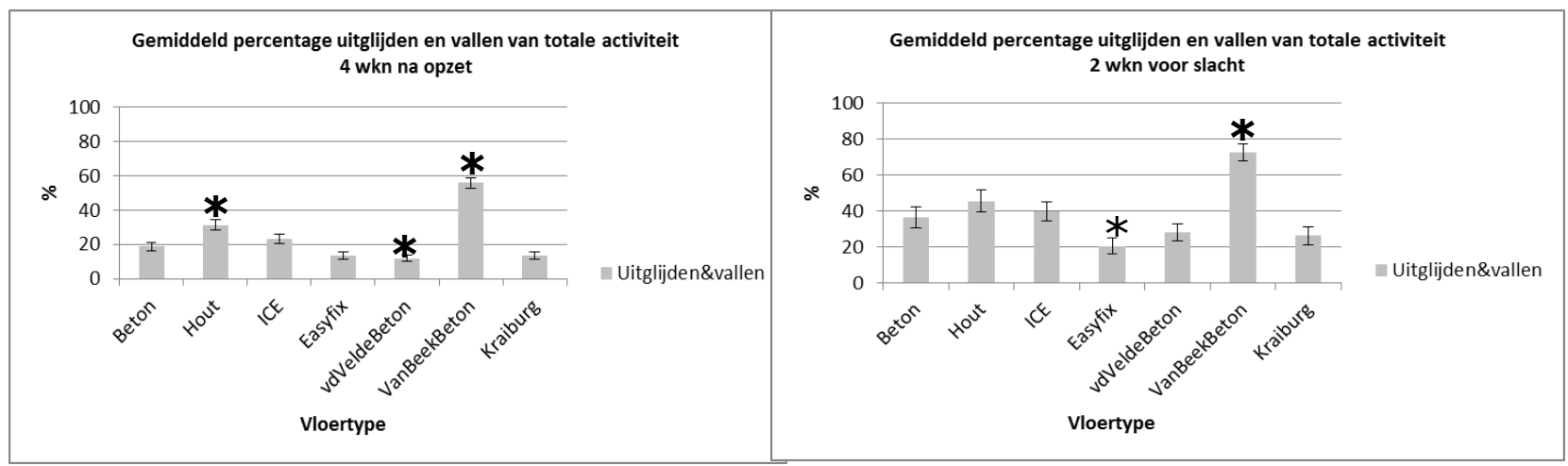

Figuur 10. Gemiddeld percentage uitglijden en vallen ten opzichte van de totale activiteit 10 weken na opzet en 2 weken voor slacht.

\section{Klinische variabelen}

Net als bij blankvleeskalveren was de prevalentie (licht of ernstig) kreupele kalveren was over het algemeen laag $(<3 \%$ op alle vloeren), en er waren geen significante verschillen tussen de referentie en alternatieve vloertypen.

In vergelijking met blankvleeskalveren werd verkregen slijmbeurs bij rosékalveren minder vaak gezien; met uitzondering van hout 2 weken voor het slachten waren gemiddelde percentages $<4 \%$. Alternatieve vloeren verschilden niet significant ten opzichte van beton in de prevalentie verkregen slijmbeurs.

\section{Pathologische variabelen}

Prevalenties van beschadigingen aan klauw en huid rond de klauw verschilden niet tussen de referentievloer enerzijds en alternatieve vloertypen anderzijds. Ten opzichte van de referentievloer nam het percentage kalveren met relatief lange klauwen het meeste toe op ICE (figuur 11). Dit verschil was statistisch significant.

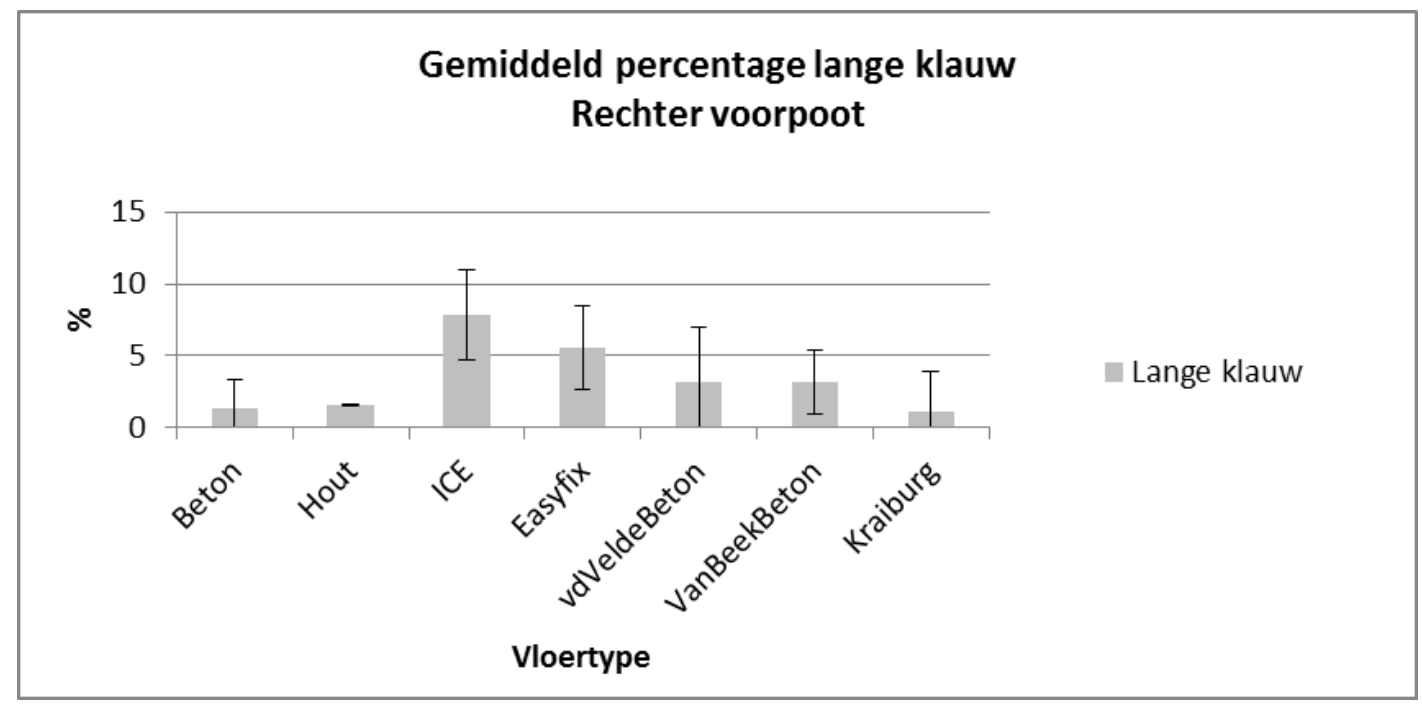

Figuur 11. Gemiddeld percentage lange klauw rechter voorpoot.

Het percentage kalveren met pathologische afwijkingen aan het karpaalgewricht van de rechter- en/of linker voorpoot was numeriek gezien van alle vloertypen het laagste op ICE (2\%), maar het verschil met de referentievloer ( $7 \%$ van de kalveren op beton met pathologische afwijkingen aan het karpaalgewricht) was niet significant.

\section{Bevuiling}

Ten opzichte van beton waren rosékalveren op hout, ICE, Easyfix en, met name, van Beek rubber op beton minder bevuild, en kalveren op van der Velde en Kraiburg meer bevuild (figuur 12). Twee weken voor het slachten waren kalveren op hout, ICE, Easyfix en van Beek rubber op beton minder 
bevuild op de buik dan kalveren op beton (figuur 12). Kalveren op van der Velde en op Kraiburg waren significant vaker bevuild op de buik dan kalveren op beton (figuur 13).

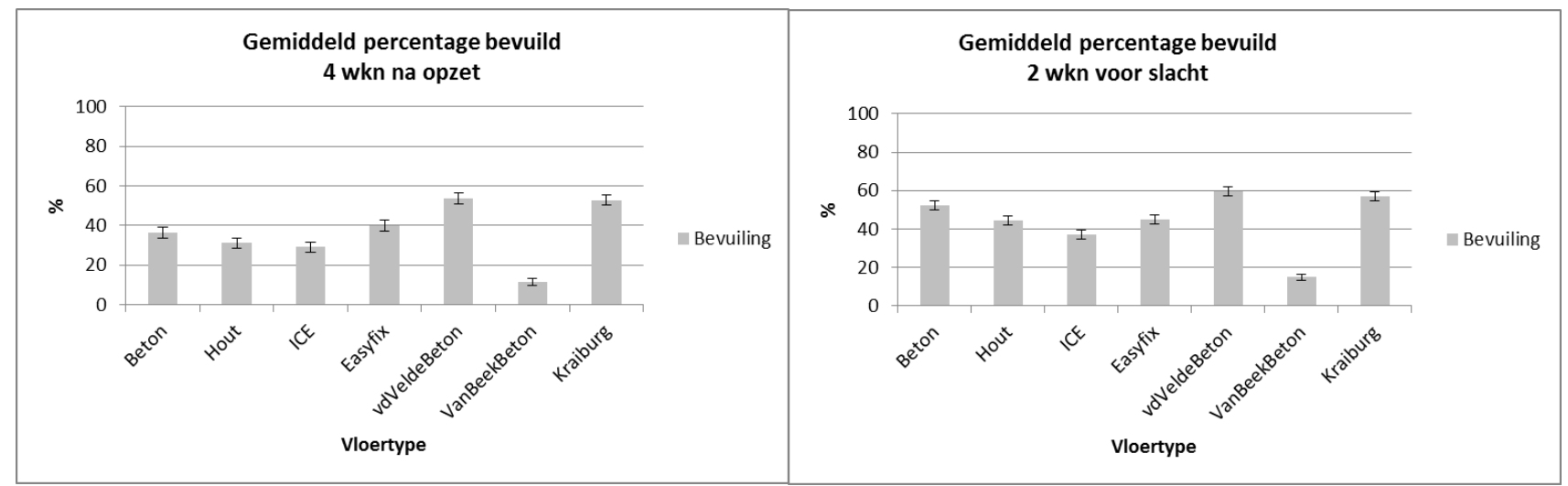

Figuur 12. Gemiddeld percentage van het kalf bevuild op 10 weken na opzet en 2 weken voor slacht.

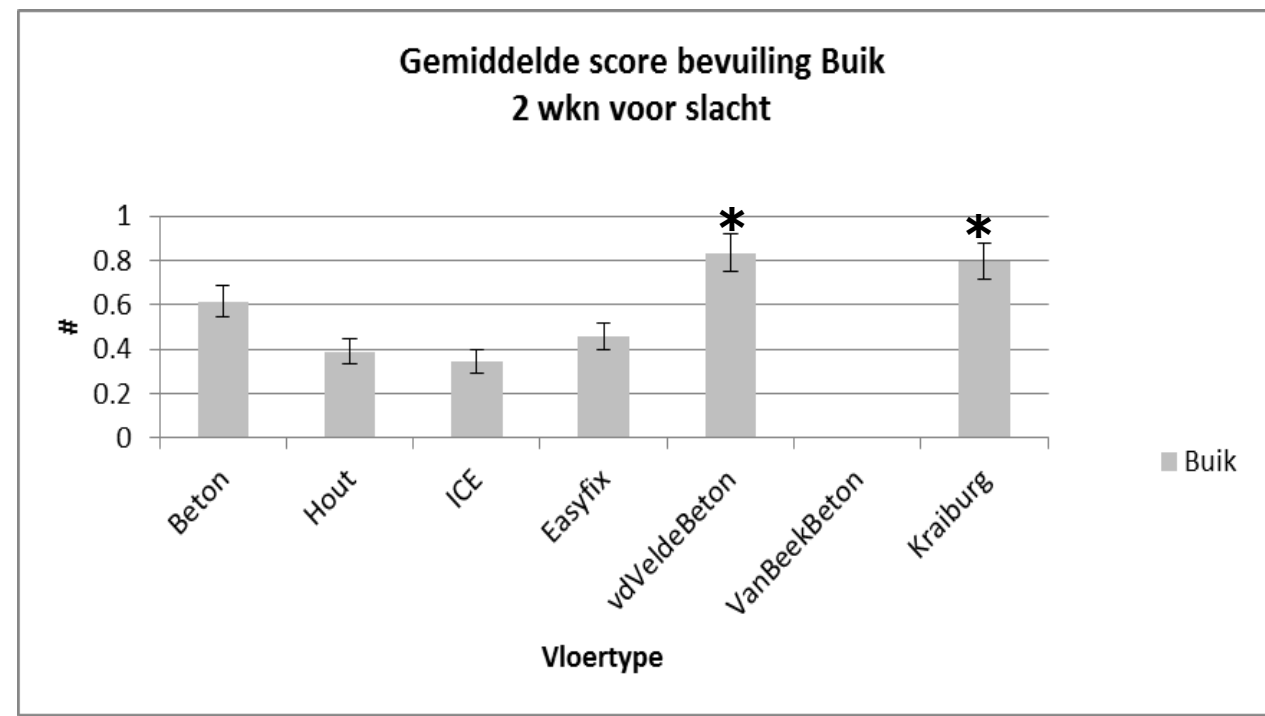

Figuur 13. Gemiddelde score voor bevuiling buik 2 weken voor slacht.

Groei

De gemiddelde groei per dag van rosékalveren op hout en op van der Velde was lager dan de gemiddelde groei per dag van rosékalveren op beton (figuur 14). De groei van kalveren op de overige alternatieve vloeren was vergelijkbaar met die van kalveren op beton (figuur 14).

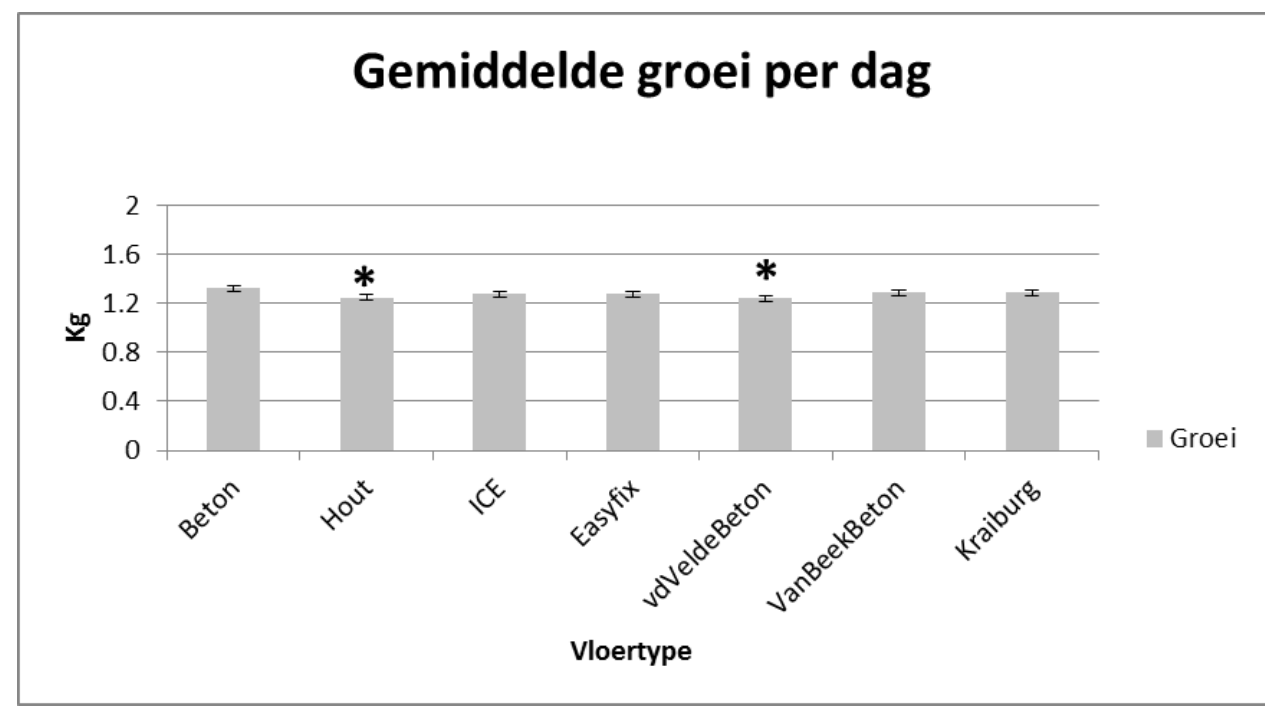

Figuur 14. Gemiddelde groei per dag $(\mathrm{kg})$. 


\subsubsection{Verkennende studie naar effect van vloertype op ammoniakemissie}

\section{Emissiemetingen}

Tussen en binnen meetperioden waren er grote variaties in gemeten ammoniakemissies*. Tussen de meeste vloertypes werden geen significante verschillen gevonden. Op de locatie met blankvleeskalveren werden wel aanzienlijk grotere verschillen in ammoniakemissie tussen vloertypes gemeten dan op de locatie met rosé kalveren. Tabel 2 toont de relatieve ammoniakemissies van de vloertypen bij blankvlees. De referentie is hier het hardhouten rooster. De emissie van de referentie is steeds op $100 \%$ gesteld. In tabel 3 worden de resultaten gepresenteerd bij rosé. Daar is het betonnen rooster de referentie.

Tabel 2. Relatieve ammoniakemissie van de diverse vloervarianten in procenten ten opzichte van de houten vloer bij blankvleeskalveren (emissie houten vloer $=100 \%$ ).

\begin{tabular}{lr} 
Vloertype (toplaag) & $\mathrm{NH}_{3}$-emisie $(\%)$ \\
Houten rooster (referentie) & $100^{\mathrm{a}}$ \\
\hline Betonrooster & 149 \\
\hline Easyfix & 110 \\
\hline ICE & $89^{\mathrm{a}}$ \\
\hline v Beek Rubber/hout & $173^{\mathrm{b}}$ \\
\hline V Beek Rubber/beton & $175^{\mathrm{b}}$
\end{tabular}

Met verschillende suffixen zijn significante verschillen $(P<0.05)$ aangegeven.

* De grote variaties in gemeten emissies hangen waarschijnlijk samen met toevallige omstandigheden (zoals de hoeveelheid verse urine op het bemeten vloerdeel); daarnaast ook met de meetmethode en de nauwkeurigheid van de meetapparatuur. Aangezien er niet op stalniveau gemeten kon worden, maar binnen afzonderlijke hokken moest de meting per meetsessie tot een klein vloeroppervlak en de ruimte daar direct boven beperkt worden.

Bij blankvlees zien we dat de range in emissies aanzienlijk is. Tussen de hoogste en laagste gemiddelde waarden zit een factor 2. De ICE vloer en de houten referentie laten hier de laagste waarden zien. De beide vloervarianten van Van Beek laten significant hogere emissies zien. Ook het betonrooster tendeert bij blankvlees naar een emissietoename ten opzichte van het gangbare houten rooster.

Tabel 3. Relatieve ammoniakemissie van de diverse vloervarianten in procenten ten opzichte van de betonnen roostervloer bij rosékalveren (emissie betonnen roostervloer $=100 \%$ ).

\begin{tabular}{lr} 
Vloertype (toplaag) & $\mathrm{NH}_{3}$-emisie $(\%)$ \\
\hline Betonrooster (referentie) & 100 \\
\hline Easyfix & 103 \\
\hline ICE & 102 \\
\hline Houten rooster & 91 \\
\hline Kraiburg & 95 \\
\hline v Beek Rubber/beton & 110 \\
\hline Van der Velde Beton(Eco-vloer) & 120
\end{tabular}

Tussen de verschillende varianten waren er op de locatie met rosé kalveren geen significante verschillen.

Tabel 3 laat zien dat de gemeten verschillen tussen de vloertypen bij rosé kalveren beduidend geringer zijn. De absolute niveaus lopen niet ver uiteen en de verschillen zijn niet significant. Het houten rooster oogt ook hier wat gunstiger.

Luchtuitwisseling tussen vloer en mestkelder op basis van tracergasinjecties

Er zijn geen significante verschillen vastgesteld in de mate van luchtuitwisseling door de roosterspleten bij de verschillende vloertypen. Bij SF6 injectie boven de vloer werd er weinig of geen tracergas onder de roostervloer (bovenin de mestkelder, midden onder de meetbox) teruggemeten. 
Door de onderdruk in de meetbox wordt een dergelijke luchtstroming waarschijnlijk ook nagenoeg volledig tegengegaan. De SF6-metingen geven geen aanleiding om te veronderstellen dat verschillen in mate van luchtuitwisseling van grote invloed zijn geweest op de uitkomsten van de emissiemetingen.

Het uitgevoerde onderzoek leert dat:

- Bij blankvlees, de beide vloervarianten van Van Beek significant ongunstiger scoren op ammoniakemissie dan de andere onderzochte vloeren;

- De overige vloeren, zowel bij blankvlees als bij rosé geen significante verschillen in (indicatief) gemeten ammoniakemissieniveaus laten zien;

- $\quad$ Er geen harde aanwijzingen zijn dat de onderzochte vloeren tot een substantiële emissiereductie van ammoniak uit vleeskalverstallen zullen leiden.

\subsubsection{Eindinspectie vloeren en ervaringen kalverhouders}

\subsubsection{Maatvoering}

Met behulp van een schuifmaat is op verschillende plaatsen op de vloer de balkbreedte en de spleetbreedte bepaald. Op één van de rosébedrijven moest dit achterwege blijven omdat het niet verantwoord geacht werd om alleen, zonder hulp of afscheidingshek, bij de zware kalveren in het hok te gaan. De resultaten zijn in tabel 4 weergegeven.

Tabel 4. Resultaten metingen aan de vloeren.

\begin{tabular}{|c|c|c|c|}
\hline & Locatie & Balkbreedte (mm) & Spleetbreedte ( $\mathrm{mm})$ \\
\hline \multirow{2}{*}{ Van Beek beton } & Rosé 1 & Niet gemeten & Niet gemeten \\
\hline & Rosé 2 & $96-98$ & $32,5-33,5$ \\
\hline \multirow{3}{*}{ Van Beek hout } & Blv 2 & $80-82$ & $31-32$ \\
\hline & Rosé 1 & - & - \\
\hline & Rosé 2 & - & - \\
\hline \multirow[t]{2}{*}{ ICE } & Blv 1 & $131-133$ & $25-27$ \\
\hline & Rosé 2 & $133-135$ & $22-23$ \\
\hline \multirow[t]{4}{*}{ Easyfix } & Blv 1 & 80 & 28 \\
\hline & Blv 2 & $79-80$ & 28 \\
\hline & Rosé 1 & Niet gemeten & Niet gemeten \\
\hline & Rosé 2 & $96-98$ & $34-35$ \\
\hline \multirow[t]{3}{*}{ Kraiburg } & Blv 1 & - & - \\
\hline & Blv 2 & - & - \\
\hline & Rosé 1 & Niet gemeten & Niet gemeten \\
\hline \multirow[t]{2}{*}{ Referentie Hout } & Blv & 79 & 30 \\
\hline & Rosé & $119 * 122 * *$ & $38 * 35 * *$ \\
\hline \multirow[t]{2}{*}{ Referentie Beton } & Blv & 70 & 25 \\
\hline & Rosé & $119 * 122 * *$ & $38 * 35 * *$ \\
\hline
\end{tabular}

* Rosé $1 * *$ Rosé 2 
Tabel 4 laat zien dat er variatie is in de spleetbreedte tussen de verschillende vloeren, maar soms ook binnen één vloertype, tussen bedrijven. Dit is het geval bij de vloeren waar met losse balkelementen is gewerkt (vooral bij Van Beek beton). De verschillen bij Easyfix tussen de blankvlees- en rosébedrijven vloeien voort uit de keuze dat Easyfix met de maatvoering van haar matten heeft aangesloten op de gangbare maatvoering van de aanwezige ondervloeren bij beide sectoren. Bij ICE lijkt het dat een klein verschil in maatvoering van balk- en spleetbreedte is ontstaan tussen blank en rosé. De balkbreedte is hier bij rosé wat groter en de spleetbreedte wat kleiner, hoewel identieke ondervloeren en afdekprofielen zijn gebruikt. Mogelijk is dit het gevolg van verschillen in belasting door de dieren. De spleet- en balkbreedte van de vloer van Van der Velden Beton is niet bemeten. Deze vloer is in de huidige uitvoering niet geschikt voor toepassing bij vleeskalveren. Ook de nieuwe en aangepaste inlays blijken niet te voldoen; er treedt beschadiging op en ze kunnen los raken uit het betonprofiel en zelfs in de mestkelder verdwijnen.

\subsubsection{Beschadigingen \& onderhoud}

Er zijn geen zichtbare beschadigingen aan de toplagen geconstateerde tijdens de inspecties. Dit werd door de kalverhouders beaamd. Wel zijn er lichte aanwijzingen dat de ICE-vloeren bij rosé wat neigt tot uitzakken, en bij de vloeren Van Beek lijkt het rubber langs het voerhek ter hoogte van de achterpoten van de kalveren wat platter te zijn geworden. Gedurende de looptijd van het project zijn soms wat herstel- en vervangingswerkzaamheden noodzakelijk gebleken.

Dit betroffen:

- $\quad$ beide type van Beek-vloeren (Iosraken van de toplaag bij enkele roosterbalken)

- $\quad$ het vervangen van alle rubber inlays van de vloer van Van der Velden Beton. Dit heeft echter nog niet tot een afdoende oplossing geleid.

- $\quad$ het versterken van de betonbalken bij de Van Beek-rubber op beton vloer bij de rosébedrijven.

\subsubsection{Beoordeling algehele reinheid vloeren}

Tijdens de eindinspectie is door de beoordelaar, onafhankelijk van het oordeel van de kalverhouder, ook een beoordeling van de reinheid van de vloer van dat moment uitgevoerd. Dit is natuurlijk een momentopname met alle beperkingen van dien, maar schakelt wel het beoordelaars-effect uit. De bevindingen zijn omgezet in een score en in tabel 5 weergegeven.

Tabel 5. Beoordeling reinheid vloeren.

$\begin{array}{lccccccc} & \text { Van } & \text { Van } & \text { ICE } & \text { Easyfix } & \text { Kraiburg } & \text { Van der } & \text { Beton } \\ \text { Beek } & \text { Beek } & & & \text { Velden Beton } & \text { Controle } \\ \text { Controle }\end{array}$

$\mathrm{G}=$ Goed, $\mathrm{M}=$ Matig en $\mathrm{S}=$ Slecht

In de beoordelingen is eenzelfde lijn terug te zien. Bij de blankvleeskalverbedrijven lijken de verschillen tussen de bedrijven wat groter, maar wordt mogelijk verklaard door het bijvoeren van vrij veel ruwvoer (stro) bij BLV 2, waardoor de mest zich meer aan de vloer hecht.

\subsubsection{Enquête gebruikerservaringen deelnemers}

De gebruikerservaringen van de deelnemers met de verschillende vloeren zijn vastgelegd aan de hand van een vragenlijst die tijdens het laatste bedrijfsbezoek met de deelnemers is doorgenomen. De bevindingen zijn in tabel 6 per hoofdaspect samengevat en gewaardeerd. De waardering is oplopend van S(lecht), M(atig) tot G(oed), met de tussenwaarderingen daarin. Een streep (-) wil zeggen dat deze vloer niet op het betreffende bedrijf aanwezig was. Een kruis $(X)$ wil zeggen dat dit aspect niet beoordeeld kon worden. Dit is bijvoorbeeld het geval bij het onderdeel reinigbaarheid op de rosébedrijven: Op deze bedrijven werden de hokken en vloeren na afloop van een ronde niet gereinigd. Men had daar dus geen ervaring mee. Over de slijtvastheid kon men geen harde uitspraken 
doen of duidelijk onderscheid tussen de vloeren aangeven. Hiervoor zijn de vloeren nog te kort in gebruik.

Tabel 6. Resultaten enquête deelnemers.

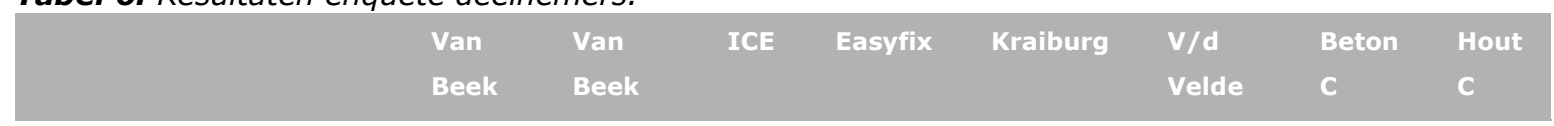

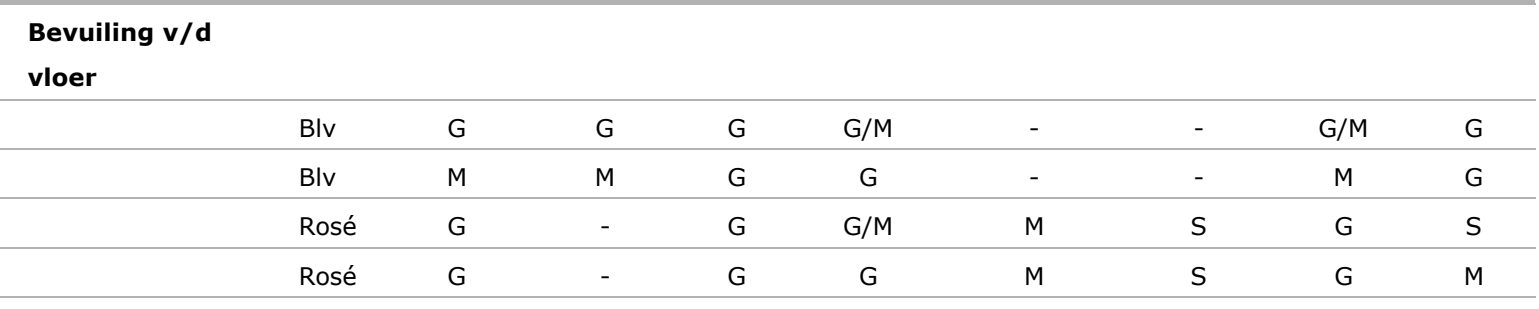

Beloopbaarheid

personen

\begin{tabular}{ccccccccc}
\hline Blv & G & G & G & G & - & - & G & G \\
\hline Blv & G & G & G & G & - & - & G & G \\
\hline Rosé & S & - & S & M & M & G & G & S/M \\
\hline Rosé & M & - & G & G & M & M & G & S \\
\hline
\end{tabular}

Reinigbaarheid

\begin{tabular}{cccccccccc}
\hline Blv & $G$ & $G$ & $G$ & $G / M$ & - & - & $M$ & $M$ \\
\hline Blv & $G$ & $G$ & $G$ & $G$ & - & - & $M$ & $M$ \\
\hline Rosé & $X$ & - & $X$ & $X$ & $X$ & $X$ & $X$ & $X$ \\
Rosé & $X$ & - & $X$ & $X$ & $X$ & $X$ & $X$ & $X$ \\
\hline
\end{tabular}

Slijtvastheid

\begin{tabular}{llllllllll}
\hline Blv & $x$ & $x$ & $x$ & $x$ & - & - & $x$ & $x$ \\
\hline Blv & $x$ & $x$ & $x$ & $x$ & - & - & $x$ & $x$ \\
Rosé & $x$ & - & $x$ & $x$ & $x$ & $x$ & $x$ & $x$ \\
\hline Rosé & $x$ & - & $x$ & $x$ & $x$ & $x$ & $x$ & $x$ \\
\hline
\end{tabular}

\section{Overall}

waardering

\begin{tabular}{cccccccccc}
\hline Blv & $G$ & $G$ & $G$ & $G$ & - & - & $G / M$ & $G$ \\
\hline Blv & $M$ & $M$ & $G$ & $G$ & - & - & $M$ & $G / M$ \\
\hline Rosé & $M$ & - & $M / G$ & $M$ & $M / S$ & $G / M$ & $G$ & $M / S$ \\
\hline Rosé & $M$ & - & $G$ & $G / M$ & $M$ & $S$ & $G$ & $S$ \\
\hline
\end{tabular}

De overall waardering geeft aan hoe de kalverhouders zelf oordelen over de geschiktheid van de verschillende vloeren voor hun kalveren.

De vleeskalverhouders zijn tevreden over hun gangbare vloeren. De blankvleeskalverhouders hebben echter wel meerwaarde ervaren van enkele van de onderzochte zachte vloeren. Bij hen scoren de ICE en de Easyfix over het geheel als beste. Voor de rosé kalverhouders ligt dit wat genuanceerder. Zij zien een minder duidelijke meerwaarde in de zachte vloeren ten opzichte van hun gangbare betonroostervloer. Ook bij deze kalverhouders komen de alternatieve vloeren van ICE en Easyfix als meest kansrijk naar voren.

Verder zijn nog wel specifieke punten en aanbevelingen per vloertype te noemen die tijdens de gesprekken naar voren zijn gebracht:

- De referentievloeren (hout $\&$ beton) blijven bij opleg van nuchtere kalveren droger dan de vloeren met een zachte toplaag.

- (Jonge) kalveren staan op beide vloeren van Van Beek te veel met de klauwen in de roosterspleten (vloeren te glad). Dit zie je bij de meer indrukbare vloeren niet. 
- $\quad$ ICE wordt wisselend beoordeeld op de beloopbaarheid door personeel: 3 maal goed en 1 maal slecht. Deze laatste beoordelaar geeft aan dat hij de vloer te glad vindt voor personen en bij het laden van kalveren.

- De Easyfix-toplaag valt de meeste kalverhouders mee. Wel geven zij de aanbeveling om de aansluiting van de mat op de ondervloer te verbeteren

- $\quad$ De vloer van Van der Velden Beton (tegenwoordig Anders Beton) is nog niet praktijkrijp. Er zijn nog technische problemen met de inlays en de mestafvoer van deze vloer is onvoldoende.

\subsection{Besluit vloeren praktijkstudie}

\subsubsection{Afweging bij keuze van vloertypen voor fase 2:}

Na afloop van fase 1 is een keuze gemaakt ten aanzien van vloertypen die in fase 2 in onderzoek werden genomen. Deze keuze is het resultaat van een afwegingsproces binnen de projectgroep en de stuurgroep. De stuurgroep maakt de beslissende keuze. In het afwegingsproces speelden een viertal elementen een rol:

(1) De prevalentie van uitglijden, de gezondheidstoestand van klauwen en gewrichten, en de bevuiling van het levende dier;

(2) Bezoedeling van karkassen, groei en emissie;

(3) De benodigde investeringskosten;

(4) Het ligcomfort.

Een vloertype dat is onderzocht in fase 1 kan in principe alleen in aanmerking komen voor verdere bestudering in fase 2, wanneer aan de volgende randvoorwaarden was voldaan:

(1) Ten opzichte van de controlevloer (hout bij blankvleeskalveren, en beton bij rosékalveren) moest er een aantoonbare verbetering zijn ten aanzien van de gezondheidstoestand van klauwen en gewrichten, en moet uitglijden van kalveren minder voorkomen.

(2) Ten opzichte van de controlevloer mocht er geen sprake zijn van een verslechtering van de bezoedeling van karkassen, de groei en de emissie.

(3) De bijbehorende investeringskosten moeten niet zo extreem hoog zijn dat de toepassing van het vloertype in de praktijk in alle redelijkheid, en gelet op de Europese context, niet haalbaar zal zijn.

Pas wanneer aan de bovenstaande randvoorwaarden was voldaan, is gekeken naar de parameter "ligcomfort". Bij gelijke geschiktheid op basis van de bovenstaande randvoorwaarden prevaleert de parameter "ligcomfort", dat wil zeggen dat dié vloertypen worden geselecteerd voor verder onderzoek in fase 2 die het meeste ligcomfort bieden.

In onderstaande tabellen zijn de proefvloeren beoordeeld t.o.v. de controle vloeren. Dit wil zeggen dat een ' 0 ' niet aantoonbaar verschilt t.o.v. de controle vloer; '-' een aantoonbare verslechtering betekent en '+'een aantoonbare verbetering inhoudt. Om een indicatie te geven van het niveau van de parameters in de uitgangssituatie zijn de resultaten van de controlevloer in tabel 7 en 8 opgenomen. 
Tabel 7. Resultaten vloeren blanke vleeskalveren.

\begin{tabular}{|c|c|c|c|c|c|c|}
\hline Criteria & $\begin{array}{l}\text { Niveau houten } \\
\text { vloer }\end{array}$ & Betonvloer & ICE & Easyfix & Van Beek-hout & Van Beek-beton \\
\hline \multicolumn{7}{|l|}{ A. Klauwen/gewrichten } \\
\hline \multicolumn{7}{|l|}{ Kreupelheid } \\
\hline 1. licht kreupel 10 weken (\%) & $4 \%$ & 0 & 0 & 0 & 0 & 0 \\
\hline 2. licht kreupel 2 weken voor slacht (\%) & $0 \%$ & 0 & 0 & 0 & 0 & 0 \\
\hline 3. ernstig kreupel 10 weken $(\%)$ & $0 \%$ & 0 & 0 & 0 & 0 & 0 \\
\hline 4. ernstig kreupel 2 weken voor slacht (\%) & $0 \%$ & 0 & 0 & 0 & 0 & 0 \\
\hline \multicolumn{7}{|l|}{ Klauwafwijkingen $(K / P)^{1}$} \\
\hline 5. verlengde klauwen (\%) & 0 & 0 & 0 & 0 & 0 & 0 \\
\hline 6. beschadiging huid/klauw (\%) & $5-10 \%^{2}$ & 0 & 0 & 0 & 0 & 0 \\
\hline \multicolumn{7}{|l|}{ Gewrichtsafwijkingen $(P)^{1}$} \\
\hline 1. carpaal gewricht ( $r$ en/of I) $(\%)$ & $23 \%$ & 0 & 0 & 0 & 0 & 0 \\
\hline Verkregen slijmbeurs $(\mathrm{K})^{3}$ & $25 \%$ & 0 & + & + & + & 0 \\
\hline \multicolumn{7}{|l|}{ B. Uitglijden en vallen ( 2 weken $<$ slacht) } \\
\hline Uitglijden en vallen (aantal) & 26 & + & 0 & + & 0 & 0 \\
\hline Uitglijden en vallen ( $\%$ van activiteit) & $73 \%$ & + & + & + & 0 & 0 \\
\hline \multicolumn{7}{|l|}{ C. Bevuiling ${ }^{4}$} \\
\hline Overall begin & & 0 & 0 & 0 & 0 & 0 \\
\hline Overall ( 2 weken < slacht) & & - & 0 & 0 & 0 & 0 \\
\hline Buik ( 2 weken < slacht) & & - & 0 & - & 0 & 0 \\
\hline D. Groei (g/dag) & 1262 & 0 & 0 & 0 & 0 & 0 \\
\hline E. Emissie & & 0 & 0 & 0 & - & - \\
\hline \multicolumn{7}{|l|}{ F. Globale investeringskosten } \\
\hline$\left(€ /\right.$ plaats $\left.=1,8 \mathrm{~m}^{2}\right)$ & $€ 80,-$ & $€ 65,-$ & $€ 250$ & $€ 90,-/ € 170,-$ & $€ 153$ & $€ 143$ \\
\hline Verbouw/nieuwbouw 5 & & & & & & \\
\hline
\end{tabular}

\section{G. Ligcomfort}

0

${ }^{1} \mathrm{~K}=$ klinisch; $\mathrm{P}=$ pathologisch

2Prevalenties per poot.

'Verkregen slijmbeurs, ook wel 'dikke knieën' genaamd, is een doorgaans niet pijnlijke - i.t.t. andere genoemde aandoeningen onder A - verdikking van de knieën (door ophoping van vocht) die het gevolg is van (overmatige) wrijving en frictie.

${ }^{4}$ De bezoedeling van de karkassen is aan de slachtlijn niet apart gescoord. Daarom is er voor gekozen de bevuiling aan het levende dier en specifiek de bevuiling van de buik hier als parameters op te voeren.

${ }^{5}$ Als er één bedrag staat zijn de kosten voor nieuw- en verbouw dezelfde. De vloersystemen kunnen dan alleen als totaal concept worden gelegd. De investeringskosten moeten worden vergeleken met de referentie hout. Feitelijk zijn de investeringskosten dan het genoemde bedrag minus de kosten van de houten roostervloer. 
(1) De prevalentie van uitglijden, de gezondheidstoestand van klauwen en gewrichten, en de bevuiling van het levende dier

- Het prevalentie kreupele kalveren is laag ( $<4 \%$ op alle vloeren). Er zijn geen aantoonbare effecten van de vloerbehandeling.

- De prevalentie van gewrichtsafwijkingen (pathologische afwijkingen aan het carpaal gewricht) is op de houten roostervloer $22 \%$. De alternatieve vloeren laten op dit punt geen verbetering zien. De ICE vloer laat een tendens zien $(p<0.10)$ tot een verminderde prevalentie van gewrichtsafwijkingen (7\%).

- De ICE-, Easyfix en Van Beek Hout vloeren laten een aantoonbare verbetering zien van het percentage verkregen slijmbeurzen. De prevalentie loopt terug van $25 \%$ op de houten roosters naar resp. 0, 4, en 7\% voor IC, Easyfix, en Van Beek Hout.

- De frequentie van uitglijden op 2 weken voor slachten is op de betonroosters en Easyfix vloer significant lager dan op de houten roosters. Het aantal keren uitglijden was op de houten vloer 26 keer gedurende 4 uur waarnemen en resp. 11 en 8 keer op de betonroosters en Easyfix vloer.

- Het percentage uitglijden van het totaal aan activiteiten rond melkverstrekking was bij beton, ICE en Easyfix wezenlijk lager dan op de houten vloer. De prevalentie liep terug van $72 \%$ op de houten roosters naar resp. 50, 51 en $46 \%$.

- $\quad$ De bevuiling van de kalveren was niet verschillend tussen de vloeren. Alleen de beton vloer scoorde op 2 weken voor slachten slechter.

- Kalveren op beton en Easyfix scoorden voor wat betreft bevuiling op de buik 2 wezenlijk slechter dan kalveren op de referentievloer.

(2) Groei en emissie

- De groei op de alternatieve vloeren was niet verschillend t.o.v. de houten roostervloer.

- $\quad$ De beide vloeren van Van Beek scoorden significant slechter op emissie.

(3) De benodigde investeringskosten

De investeringskosten voor nieuwbouw variëren van $€ 143,--€ 250$, - per kalverplaats. Vergeleken met de kosten voor de huidige houten roostervloer zijn de meer investeringskosten $€ 63$, - - $€ 170$, -. Uitgaande van een afschrijving in 10 jaar (= ca $15 \%$ jaarkosten voor afschrijving, rente en onderhoud) en een karkasproductie van netto $117 \mathrm{~kg}$ karkas (143 kg - 25 $\mathrm{kg}$ nuka) per ronde $\times 1,8$ ronde $=210 \mathrm{~kg}$ karkas dan bedragen de meerkosten per $\mathrm{kg}$ karkas 4,5 tot 12 cent. Andersom geredeneerd om de extra investeringen terug te verdienen in 10 jaar moet de karkasopbrengst $(\mathrm{kg})$ met ca. $€ 15$, - per jaar/kalverplaats toenemen oftewel ruim $3 \mathrm{~kg}$ karkas. Dit betekent 1,5\% (3/210) extra karkasgroei.

Voor de ICE vloer zijn de meerkosten uitgaande van een compleet rooster $€ 250$, -/kalverplaats. Daarmee zijn de meerkosten per kg karkas 12 cent.

(4) Het ligcomfort

De blanke vleeskalveren hebben een uitgesproken voorkeur voor de alternatieve vloeren als ligen rustplaat. Ze laten voor alle alternatieve vloeren m.u.v. het betonrooster een duidelijke voorkeur zien.

\section{Discussie en conclusie}

Uit het onderzoek komt een minimale prevalentie van kreupelheid naar voren op de houten vloer. Voor de criteria 'afwijkende klauwen' en 'afwijkende gewrichten' zijn geen statistisch significante verschillen t.o.v. de houten controlevloer aangetoond. Alternatieve vloeren leiden op dit punt niet tot een aantoonbare verbetering. De ICE en Easyfix vloeren laten een lagere prevalentie van verkregen slijmbeurzen zien. Voor alle alternatieve vloeren geldt dat de kalveren aan deze vloeren de voorkeur geven als ligplaats.

Er zijn geen verschillen in groei aangetoond. Wat de emissies betreft zijn Van Beek Hout en Van Beek Beton aantoonbaar slechter. Zachte vloeren leiden tot een substantiële kostenverhoging (4,5 - $12 \mathrm{ct}$. per kg karkasgewicht). Of dit door gunstiger technische resultaten kan worden terugverdiend moet uit 
het vervolgonderzoek met grotere dieraantallen blijken. De kalverhouders zelf (enquête) zagen voordelen in de zachte vloeren Easyfix en ICE voor hun kalveren (comfortabeler en minder hokbevuiling) en voor de reinigingstijd.

Besluit

De leden van de projectgroep zijn het eens dat bij blankvleeskalveren ICE en Easyfix als betere vloeren uit fase 1 komen.

De projectgroep stelt voor om de fabrikant gelegenheid te bieden de vloerontwerpen enigszins aan te passen zodat de vloer meer kan bijdragen aan een reductie van de ammoniakemissie zonder dat het welzijn van de kalveren achteruit gaat. Fabrikanten moeten in ieder geval aantonen dat het principe van hun vloeren ongewijzigd blijft. 
Tabel 8. Resultaten vloeren rosé vleeskalveren.

\begin{tabular}{|c|c|c|c|c|c|c|c|}
\hline Criteria & $\begin{array}{l}\text { Niveau } \\
\text { betonvloer }\end{array}$ & Hout & ICE & Easyfix & $\begin{array}{c}\text { Van der } \\
\text { Velden Beton }\end{array}$ & $\begin{array}{l}\text { Van Beek- } \\
\text { beton }\end{array}$ & Kraiburg \\
\hline \multicolumn{8}{|l|}{ A. Klauwen/gewrichten } \\
\hline \multicolumn{8}{|l|}{ Kreupelheid } \\
\hline 1. licht kreupel 10 weken (\%) & $0 \%$ & 0 & 0 & 0 & 0 & 0 & 0 \\
\hline 2. licht kreupel 2 wk v slacht (\%) & $0 \%$ & 0 & 0 & 0 & 0 & 0 & 0 \\
\hline 3. ernstig kreupel 10 weken (\%) & $0 \%$ & 0 & 0 & 0 & 0 & 0 & 0 \\
\hline 4. ernstig kreupel $2 \mathrm{wk} \vee$ slacht (\%) & $0 \%$ & 0 & 0 & 0 & 0 & 0 & 0 \\
\hline \multicolumn{8}{|l|}{ Klauwafwijkingen $(K / P)^{1}$} \\
\hline 1. verlengde klauwen (\%) & 1 & 0 & 0 & 0 & 0 & 0 & 0 \\
\hline 2. beschadiging huid/klauw (\%) & $<5 \%^{2}$ & 0 & 0 & 0 & 0 & 0 & 0 \\
\hline \multicolumn{8}{|l|}{ Gewrichtsafwijkingen $(P) 1$} \\
\hline 1. carpaal gewricht ( $r$ en/of I) $(\%)$ & $7 \%$ & 0 & 0 & 0 & 0 & 0 & 0 \\
\hline Verkregen slijmbeurs $(\mathrm{K})^{3}$ & $1 \%$ & 0 & 0 & 0 & 0 & 0 & 0 \\
\hline
\end{tabular}

\section{B. Uitglijden/vallen;2 wk.<slacht}

Uitglijden/vallen (aantal)

Uitglijden/vallen (\% van activiteit)

6

$36 \%$

$\begin{array}{ll}- & 0 \\ 0 & 0\end{array}$

$\begin{array}{lll}0 & 0 & 0\end{array}$

0

$\begin{array}{ll}- & 0 \\ - & 0\end{array}$

\section{Bevuiling ${ }^{4}$}

Overall begin

Overall (2 weken < slacht)

Buik ( 2 weken < slacht)

$\begin{array}{ll}0 & + \\ + & + \\ + & +\end{array}$

D. Groei (g/dag) $1320 \quad-$

E. Emissie

0

0

$+$

\begin{tabular}{|c|c|c|c|c|c|c|c|}
\hline $\begin{array}{l}\text { Investeringskosten } \\
\left(€ / \text { plaats }=1,8 \mathrm{~m}^{2}\right) \\
\text { Verbouw } / \text { nieuwbouw }^{5}\end{array}$ & $€ 65,-$ & $€ 80,-$ & $\begin{array}{l}€ 170,-/ \\
€ 235,-\end{array}$ & $€ 90,-/ € 155$ & $€ 225$ & $€ 143$ & $€ 104,-/ € 169,-$ \\
\hline
\end{tabular}

G. Ligcomfort

0

$+$

$(+)$

0

$+$

0

${ }^{1} \mathrm{~K}=$ klinisch; $\mathrm{P}=$ pathologisch .

2Prevalenties per poot.

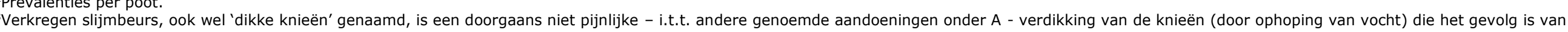
(overmatige) wrijving en frictie.

${ }^{4}$ De bezoedeling van de karkassen is aan de slachtlijn niet apart gescoord. Daarom is er voor gekozen de bevuiling aan het levende dier hier als parameter op te voeren.

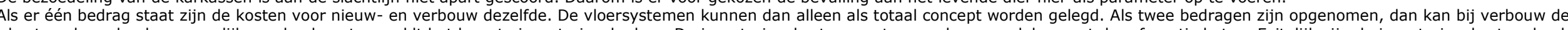

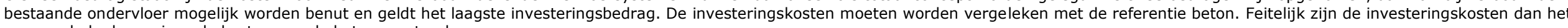




\section{Toelichting tabel 8}

(1) De prevalentie van uitglijden, de gezondheidstoestand van klauwen en gewrichten, en de bevuiling van het levende dier

- De prevalentie kreupele kalveren is laag (<3\% op alle vloeren). Er zijn geen aantoonbare effecten van het type vloer.

- Het percentage afwijkingen carpaal gewrichten aan linker en/of rechter voorpoot is op het betonrooster 7\%. Dit werd niet wezenlijk beïnvloed door het vloertype. Bij ICE was het niveau met $2 \%$ afwijkingen aan het carpaal gewricht het laagst.

- Ook de effecten op het percentage kalveren met verkregen slijmbeurzen is niet verschillende tussen de vloeren. De prevalentie op beton is aan het einde van de mestperiode op het betonrooster $1 \%$, terwijl hout $8 \%$ scoort (N.B. het houten rooster bij rosé heeft bredere latten dan bij de blanke vleeskalveren) en Van Beek-beton 4\%. ICE en Easyfix laten zowel aan het begin als aan het eind van de mestperiode geen verkregen slijmbeurzen zien.

- De frequentie van uitglijden op 2 weken voor slachten in absolute zin was op de betonrooster gering (ca. 6 keer). De Van Beek Beton vloer scoort hier beduidend slechter met 67 keer. De andere vloeren waren niet verschillend t.o.v. beton.

- Het percentage uitglijden van het totaal aan activiteiten was voor beton $36 \%$. Alleen de Easyfix vloer scoorde met $21 \%$ wezenlijk beter. Ook hier was de Van Beek Beton vloer beduidend slechter met $73 \%$.

- De bevuiling van de kalveren was verschillend tussen de vloeren. Aan het eind van de mestperiode waren de kalveren op hout, ICE, Easyfix en Van Beek Beton schoner dan op beton. Alleen Van der Velden Beton vloer liet een verslechtering zien. Ook al in het begin van de mestperiode scoorden ICE en Van Beek Beton beter. Daarentegen scoorden Van Beek Beton en Kraiburg slechter.

- De bevuiling op de buik 2 weken voor slachten laat zien dat Van Beek Beton, ICE, Easyfix, en hout aantoonbaar beter scoren dan de referentie vloer.

\section{(2) Groei en emissie}

- De groei op de alternatieve vloeren was voor de houten en Van der Velden betonrooster wezenlijk slechter (6\%) t.o.v. de betonnen roostervloer.

- $\mathrm{Er}$ is geen verschil in emissie aangetoond.

(3) De benodigde investeringskosten

Uitgaande van nieuwbouw zijn de investeringskosten voor rosé vergelijkbaar met die bij blank. Ook de berekeningen op basis van karkasgewicht ontlopen elkaar niet echt. Op jaarbasis levert een rosé kalverplaats ca. 1,5 ronde $\times(155-25)=195 \mathrm{~kg}$ karkas op. De referentievloer (beton) is hier wat goedkoper.

(4) Het ligcomfort

Alleen de ICE vloer en Van Beek Beton vloer geniet bij de rosé kalveren een duidelijke voorkeur boven beton. Voor Easyfix is dit bijna significant aantoonbaar $(p=0,058)$. Op 4 weken na opzetten is het verschil bijna significant voor de ICE vloer $(p=0,052)$.

\section{Discussie en conclusie}

De uitkomsten bij de rosé kalveren zijn beduidend minder uitgesproken dan bij de blanke vleeskalveren. Wel kunnen we constateren dat de resultaten voor rosé over het algemeen dezelfde kant op bewegen als bij de blanke kalveren. De meeste '+-en' worden door Easyfix en ICE gescoord waarbij geen enkele '-' wordt gezien. Van Beek Beton scoort goed op bevuiling echter op uitglijden pakt de vloer slecht uit. De vloer van Van der Velden Beton heeft nog veel technische problemen en is nog niet praktijkrijp. De deelnemende rosé kalverhouders beoordelen de gunstigste zachte vloeren (Easyfix en ICE) als gelijkwaardig, maar niet duidelijk beter, dan hun huidige betonroostervloer.

Besluit

De leden van de projectgroep zijn het eens dat ICE en Easyfix ook bij rosékalveren als betere vloeren uit fase 1 komen. 
De projectgroep stelt voor om de fabrikant gelegenheid te bieden de ontwerpen enigszins aan te passen zodat de vloer bijdraagt aan een reductie van de emissie zonder dat het welzijn van de kalveren achteruit gaat. Fabrikanten moeten in ieder geval aantonen dat het principe van hun vloeren ongewijzigd blijft.

\section{Aanpassingen vloeren t.b.v. fase 2 (de praktijkstudie)}

Naar aanleiding hiervan zijn de volgende aanpassingen aan de zachte vloeren gedaan:

\section{Easyfix}

De Easyfix toplaag is aangepast op de volgende punten.

- Naar aanleiding van de gunstige ervaring met bredere balken bij rosé heeft Easyfix samen met Van Beek een vleeskalvervloer ontwikkeld met een balkbreedte van $12 \mathrm{~cm}$ en een spleetbreedte van $30 \mathrm{~mm}$. De bijpassende ondervloer kan uitgevoerd worden in beton of in hout en heeft een maatvoering van $11 \mathrm{~cm}$ balk en $40 \mathrm{~mm}$ spleet. De rubber mat steekt derhalve ca $5 \mathrm{~mm}$ over boven met mestspleet. Aan de zijkanten van de rubbermat zijn korte zijstukjes (rokjes) aangebracht om te voorkomen dat mest tussen de roosterbalk en de rubber mat gaat vloeien.

- De bolling van de bovenzijde van de mat is in het midden iets verhoogd en naar beide zijden licht afgevlakt.

- $\quad$ Er is hamerslagprofiel aangebracht

- Dwars op de lengterichting zijn om de $50 \mathrm{~cm}$ rubber strips in de matten geïntegreerd om de kalveren extra grip te bieden.

Voor bestaande rosé-stallen met goede betonroosters biedt Easyfix maatwerkoplossingen met een tailormade mat die, in plaats van $10 \mathrm{~mm}, 6 \mathrm{~mm}$ breder is dan de roosterbalk, waardoor de mestspleet daar ook effectief rond $30 \mathrm{~mm}$ blijft liggen. Easyfix heeft geen extra vloeruitvoering ingebracht waarvan een hogere emissiereductie wordt verwacht.

ICE:

De maatvoering van de mat van ICE is niet gewijzigd. De spleetbreedte (inclusief mat) is wat verruimd naar ca $30 \mathrm{~mm}$. Bij de ICE toplaag is de indrukbaarheid aangepast naar het eindgewicht van de kalveren die er op worden gehouden. ICE heeft van de mogelijkheid gebruik gemaakt om een uitvoering aan te bieden met naar verwachting extra emissiereductie: namelijk door de vloer te voorzien van afsluitende kleppen in de roosterspleet. Deze participeert als demo-emissies in de praktijkstudie.

De project en stuurgroep hebben ingestemd met deze aanpassingen. 


\section{$4 \quad$ Praktijkstudie}

\subsection{Materiaal en Methode}

\subsubsection{Materiaal}

De proefopzet van de praktijkstudie staat schematisch weergegeven in tabel 9. Opzet was het onderzoek uit te voeren op 20 bedrijven, 10 blankvleesbedrijven en 10 rosébedrijven gedurende drie mestronden.

Uiteindelijk hebben 14 vleeskalverbedrijven aan het onderzoek deelgenomen: 8 blankvleesbedrijven en 6 rosébedrijven, waarvan twee 'oud' rosé (ca. 9 maanden slachtleeftijd) en vier 'jong' rosé ( 8 maanden slachtleeftijd). Om tot hetzelfde aantal experimentele eenheden te komen zijn het aantal mestronden op de bedrijven uitgebreid. Voor de rosébedrijven betekende dit in totaal 5 mestronden. Voor de blanke bedrijven bedroeg het aantal mestronden 4, m.u.v. een bedrijf waar 3 mestronden zijn gevolgd. Dit verklaart mede de langere duur van het onderzoek. In de opzet van het onderzoek fungeerde afdeling binnen ronde als experimentele eenheid. Om statistisch gezien een betrouwbare uitspraak te kunnen doen over de effecten van de alternatieve vloeren - d.w.z. een uitspraak met voldoende 'power' - waren minimaal 30 experimentele eenheden nodig.

Beschrijving van de alternatieve vloeren

Op elk bedrijf zijn drie verschillende vloeren met elkaar vergeleken: één controle (voor blank is dit een hout lattenrooster en voor rosé betonnen roosters) en twee alternatieven, respectievelijk ICE en Easyfix. Beide vloeren zijn uit de voorstudie gekozen voor verder onderzoek.

Om een goede aansluiting te krijgen met de ondervloer zijn de alternatieve vloeren op de blankvleesbedrijven op nieuwe houten roosters gelegd. De proefvloeren op de rosébedrijven zijn zoveel mogelijk op de bestaande betonnen roostervloeren gelegd. In een aantal gevallen zijn de roosters aan de zijkanten van de balken hiervoor bijgeslepen voor een goede aansluiting met de toplagen. De vloeren in de controleafdelingen moesten in goede staat verkeren en zijn niet vervangen of aangepast. Voor een beschrijving van de beide alternatieve vloeren zie bijlage 4 .

Deelnemende bedrijven moesten aan een aantal voorwaarden voldoen:

1) Elk deelnemend bedrijf heeft drie volledige afdelingen beschikbaar, voor elke vloertype één. Binnen de afdeling moeten alle groepshokken volledig van het betreffende vloertype worden voorzien.

2) Voor de controlevloer is gebruik gemaakt van hetzij de bestaande vloer, hetzij een nieuwe vloer (bij nieuwbouw). Voor geschiktheid van de bestaande vloer werd de vloer ter plekke beoordeeld.

3) De afdelingen zijn klimaat gescheiden ruimten waarbij bovenbouw en kelders fysiek van elkaar gescheiden zijn zodat er geen uitwisseling van lucht tussen afdelingen kan plaatsvinden.

4) Herkomst kalveren: Benelux en Duitsland.

Voor deelname aan het onderzoek werd een overeenkomst getekend tussen de kalverhouder/eigenaar en Wageningen Livestock Research. Hierin is opgenomen dat de kalverhouder bereid is gegevens beschikbaar te stellen t.b.v. het onderzoek en de bedrijfsvoering af te stemmen op de wensen vanuit het onderzoek. Ter compensatie krijgen de kalverhouders per mestronde een vergoeding voor de extra werkzaamheden. Tevens hebben de kalverhouders een subsidieaanvraag gedaan van $60 \%$ op de investeringskosten via een artikel 68 regeling van het ministerie.

De drie vloertypen werden middels loting over de afdelingen verdeeld. De situatie werd op elk deelnemend bedrijf vooraf met een intake-bezoek beoordeeld. Binnen elk deelnemend bedrijf werden kalveren bij opzet willekeurig over de afdelingen verdeeld. 
Tabel 9. Schematische weergave proefopzet.

\begin{tabular}{|c|c|c|c|c|c|c|c|c|c|c|}
\hline & & \multicolumn{3}{|c|}{ Mestronde 0} & \multicolumn{3}{|c|}{ Mestronde 1} & \multicolumn{3}{|c|}{ Mestronde 2} \\
\hline & & A & B & $\mathrm{C}$ & A & $\mathrm{B}$ & $\mathrm{C}$ & A & B & C \\
\hline \multirow[t]{2}{*}{ Blank } & 1 & $\mathrm{X}^{1}$ & $x$ & $x$ & $x$ & $x$ & $x$ & $x$ & $x$ & $x$ \\
\hline & 2 & $X$ & $x$ & $x$ & $x$ & $x$ & $x$ & $x$ & $x$ & $\mathrm{x}$ \\
\hline \multirow[t]{4}{*}{ Rosé } & 1 & $x$ & $x$ & $x$ & $x$ & $x$ & $x$ & $x$ & $x$ & $x$ \\
\hline & 2 & $X$ & $x$ & $x$ & $x$ & $X$ & $X$ & $X$ & $x$ & $\mathrm{X}$ \\
\hline &.. & .. &.. &.. &.. &.. &.. & .. & .. & .. \\
\hline & 10 & $X$ & $x$ & $x$ & $x$ & $x$ & $x$ & $X$ & $x$ & $\mathrm{x}$ \\
\hline
\end{tabular}

${ }^{1}$ Een cel met $x$ betekent dat de betreffende afdeling deel uitmaakt van het onderzoek.

\subsubsection{Methode/waarnemingen}

Bij de waarnemingen werd onderscheid gemaakt tussen waarnemingen aan het dier, stalklimaat en vloeren. Tijdens de eerste mestronde, de zogenaamde 0-ronde, worden alleen de technische resultaten en behandelingen met diergeneesmiddelen vastgelegd. In de daaropvolgende ronden worden ook nog waarnemingen aan het dier, stalklimaat en vloeren gedaan. Voor blank en rosé zijn in een tijdsschema de metingen aangegeven (resp. figuur 15 en 16). Op basis van de verkregen resultaten is een economische evaluatie uitgevoerd.

$\mathrm{Na}$ afloop van de proef is tot slot een enquête uitgevoerd bij de kalverhouders waarin de ervaringen van de vloeren en het onderzoek zelf zijn gevraagd en vastgelegd.

De waarnemingen vinden plaats op drie niveaus: dier, vloer en stalklimaat.

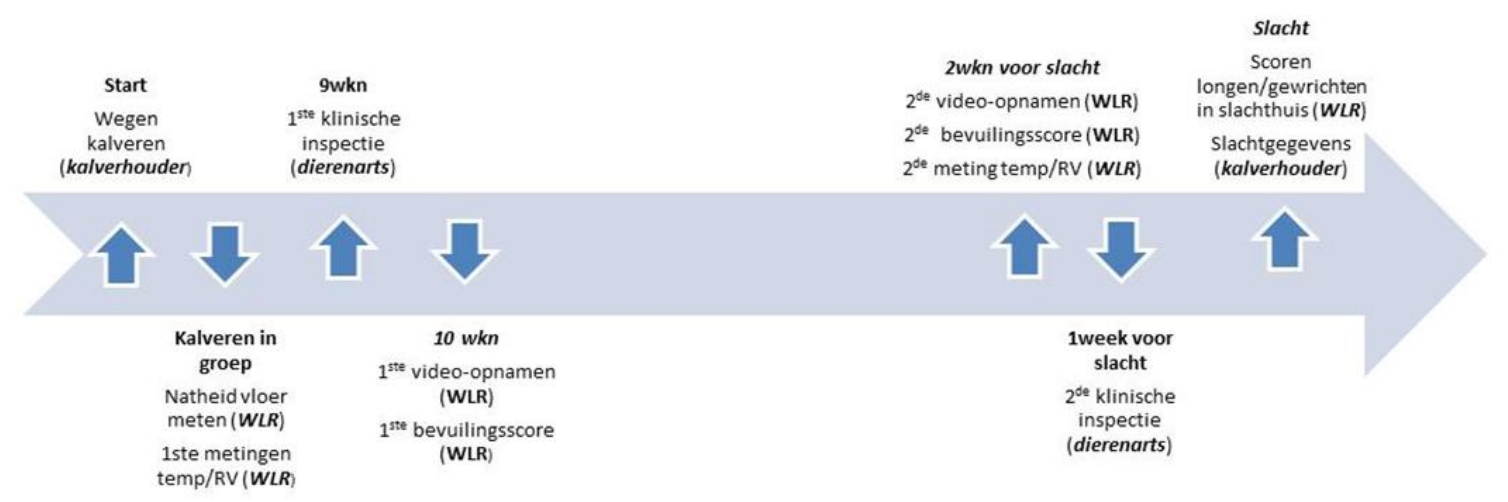

Figuur 15. Tijdsschema waarnemingen per ronde voor blankvleesbedrijven (m.u.v. ronde 0). 


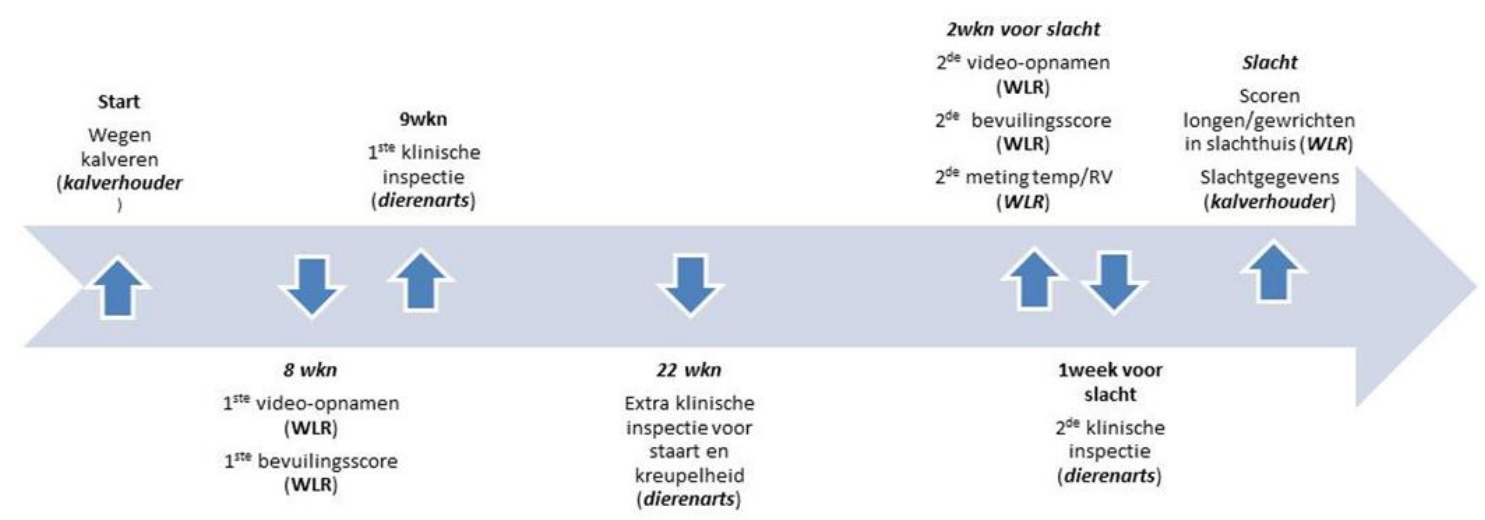

Figuur 16. Tijdsschema waarnemingen per ronde voor rosé bedrijven (m.u.v. ronde 0).

\section{Waarnemingen dier}

De waarnemingen aan het kalf waren: (a) gedrag, (b) klinische gezondheid, (c) pathologie (post mortem onderzoek), (d) bevuiling en bezoedeling, (e) technische resultaten en (f) behandelingen met diergeneesmiddelen.

(a) Gedrag

Gedragswaarnemingen zijn uitgevoerd met behulp van videoapparatuur. Van elke afdeling zijn bij vier willekeurige hokken gedurende 24 uur video-opnamen gemaakt. Hiervan werden twee hokken uitgelezen met behulp van The Observer XT 10. De opnamen ('real time') vonden plaats op twee leeftijden gedurende een periode van 24 uur. De eerste leeftijd was voor blankvleeskalveren 10 weken na opzetten, en voor rosékalveren 8 weken na aanvang van de afmestfase. De tweede leeftijd was voor zowel blankvlees- als rosékalveren twee weken vóór het slachten. De uitleesperiode richtte zich op het gedrag rond voeren en betrof een uur voor en een uur na de twee voerbeurten. Onderstaande gedragingen zijn als frequenties (aantallen) gescoord.

Ethogram:

Uitglijden:

Kalf glijdt met 1 of meerdere poten uit.

Bespringen:

Kalf springt met voorpoten op de rug of kop van ander kalf

Vallen: Kalf komt met flank op grond terecht.

Dartelen/rennen: Kalf rent en/of komt met 2 of meer poten van de vloer

Vechten:

Kalf staat met ander kalf "kop tegen kop" en probeert het andere kalf weg te duwen. Of stoot het andere kalf weg tegen zijn kop of flank.

De opnamen zijn in mestronde 1 en 2 gemaakt. De opnames uit mestronde 1 zijn uitgelezen.

(b) Gezondheid

De klinische inspectie is uitgevoerd door gespecialiseerde vleeskalverdierenartsen en gebaseerd op het protocol klinische gezondheid ontwikkeld binnen de welzijnsmonitor (zie bijlage 5). In dit onderzoek lag de nadruk op de gezondheidstoestand van klauwen en gewrichten en het vóórkomen van kreupelheid. Daarnaast waren van belang de gezondheid van het ademhalingssysteem (zie Pathologie) en het vóórkomen van verteringsstoornissen en diarree.

Per afdeling werden in totaal 8 hokken klinisch beoordeeld. Deze hokken werden vooraf willekeurig (random) gekozen. Elke ronde vond op twee momenten een klinische inspectie plaats, op 9 weken na opstart/aanvang mestfase en 2 weken voor het slachten. 
(c) Pathologie

De longen werden op het slachthuis beoordeeld door medewerkers van de afdeling Pathologie van het Wageningen Bioveterinary Research volgens het protocol pathologie longen (bijlage 6). Dit protocol is eveneens ontwikkeld binnen de welzijnsmonitor. Per afdeling zijn minimaal 20 random gekozen longen onderzocht. De aantallen zijn afhankelijk van het aantal leveringen (vrachten) waarin een koppel kalveren (afdeling) naar het slachthuis is vervoerd.

(d) Bevuiling en bezoedeling

De bevuiling van het kalf werd bij alle hokken per afdeling voor de blankvleesbedrijven en 10 hokken per afdeling voor de rosé bedrijven. beoordeeld volgens het protocol zoals ook toegepast in fase 1 van het project (bijlage 7).

De beoordeling van de bezoedeling van karkassen werd uitgevoerd op het slachthuis volgens het slachthuisprotocol. Dit protocol verschilde per slachthuis, echter kwam het op het volgende neer: Elk binnenkomend koppel ( = vrachtwagen) wordt beoordeeld op bevuiling. Focus ligt op het middenstuk van het kalf (voorhand, buik en achterhand). Beoordelingen zijn:

- Schoon

- Vuil droog

- Vuil nat (transport)

- Te vuil of zeer vuil droog

- Te vuil of zeer vuil nat (transport)

Bij blankvleeskalveren vond op het bedrijf een extra beoordeling van de bevuiling plaats in de eenlingboxen vlak voor de overgang naar de groepshuisvesting. Tijdens die inspectie werd ook specifiek gekeken naar de natheid van de vloer.

(e) Groei en voeropname

De voeropname en samenstelling van de verschillende voedermiddelen werd door de kalverhouder per afdeling vastgelegd gedurende alle mestronden (vanaf ronde-0). Na afloop is voor de rosé bedrijven alle opgenomen kilo product omgerekend naar droge stofopname, en vervolgens naar VEVI-opname per kalf per dag. Daaruit is een voederconversie berekend - kVEVI - gedefinieerd als: VEVI-opname per kalf per dag gedeeld door de groei per kalf per dag (kg). kVEVI geeft de opgenomen VEVI per kg groei weer. Voor blankvleeskalveren is de droge stof opname (in $\mathrm{kg}$ per kalf per dag) bepaald voor zowel de melkpoeder als het ruwvoer. De droge stof opname aan ruwvoer is omgezet in zogenaamde kalvermelk equivalenten (in $\mathrm{kg}$ per kalf per dag) aan de hand van de schattingsmethode ontwikkeld in eerder onderzoek van Wageningen UR in samenwerking met de Nederlandse vleeskalversector (Berends et al., 2014; Mollenhorst et al., 2016). Deze omzetting hield in dat de droge stof opname aan ruwvoer (in $\mathrm{kg}$ per kalf per dag) werd gedeeld door 1,43. De totale droge stof opname van blankvleeskalveren (in kg per kalf per dag) werd berekend als de som van: (i) de droge stof opname aan melkpoeder (in kg per kalf per dag) en (ii) de droge stofopname aan ruwvoer (in keg per kalf per dag) uitgedrukt in kalvermelkequivalenten.

$\mathrm{Bij}$ aankomst op het bedrijf werd het gewicht van de kalveren per afdeling vastgelegd. Rosékalveren op een gesloten bedrijf zijn niet gewogen bij de overgang van het opfokbedrijf naar de proefafdeling. Het eindgewicht (karkas) werd vastgelegd op het slachthuis.

(f) Gebruik diergeneesmiddelen

Kalverhouders hebben i.s.m. de dierenarts het medicijngebruik (individueel en koppelbehandelingen) vastgelegd.

Waarnemingen vloeren

Waarnemingen aan de vloeren vinden plaats ten aanzien van de volgende eigenschappen:

1. Duurzaamheid van de materiaaleigenschappen (flexibiliteit, indrukbaarheid, vormvastheid en slijtage) in de tijd

2. Het optreden van materiaalbeschadigingen

3. De bevestiging aan de ondervloer

4. De grip/tredvastheid

5. De reinigbaarheid / reinigingstijd 
Ad 1:

Voor het vaststellen van de vloer- en materiaalkenmerken (zoals indrukbaarheid, vormvastheid, slijtage) heeft de DLG (Deutsche Landwirtschaftliche Gesellschaft) de zogenaamde Fokus -test voor vloermatten ontwikkeld. Dit is een algemeen geaccepteerd testprotocol waarin de genoemde duurzaamheidsaspecten worden onderzocht en in een meetrapport worden vastgelegd. Deze test is in opdracht van beide fabrikanten bij DLG uitgevoerd. (DLG Prufbericht 5993F en 5924F)

De Fokus test is bij de Easyfix uitgevoerd met de toplaag die in fase 1 is toegepast. In fase 2 is de vorm van de toplaag van vlak naar bol aangepast en het profiel van de toplaag gewijzigd. Van de ICE vloer is ook een Signum test uitgevoerd (DLG Prufbericht 5991) daarbij is ook de toepassing van de mat onder praktijkomstandigheden bekeken en het gedrag van de dieren vastgelegd.

Ad 2, 3 en 5:

Voor het vastleggen van de algemene gebruikerskenmerken en ervaringen werd bij alle kalverhouders een logboek gelegd waarin opmerkelijke zaken, vervangingen en ervaringen door de gebruiker kunnen worden opgetekend.

Verder zijn de alternatieve vloeren op alle bedrijven na afloop van ronde 2 en aan het einde van de proef geïnspecteerd. Hierbij is met name gekeken naar eventuele beschadigingen van de toplaag en zijn veranderingen in de breedte van de toplaag en de spleetbreedte op verschillende plaatsen in de hokken gemeten.

Ad 4:

De grip/ tredvastheid voor de kalveren is beoordeeld aan de hand van de gedragsobservaties. Voor de beloopbaarheid van de vloeren voor de kalverhouder is gezocht naar een objectieve test. In overleg met een hierin gespecialiseerd bureau (Aveco De Bondt) is gekozen voor een stroefheidsbepaling met behulp van een TRIBO-meter. Met de TRIBO-meter wordt de slipweerstand van oppervlakken bepaald volgens ontwerpnorm NEN 7909:2015. Deze norm geeft de eis ten aanzien van de slipweerstand van horizontale en hellende, beloopbare oppervlakken in een openbare ruimte of arbeidsruimte en de daarbij behorende bepalingsmethode. De slipweerstand wordt geclassificeerd met een dynamische wrijvingscoëfficiënt en geeft uitsluitsel over de beloopbaarheid van oppervlakken. De norm is van toepassing op beloopbare oppervlakken die geheel 'in het werk' zijn gemaakt of samengesteld. Met de in de norm voorgeschreven bepalingsmethode wordt de actuele slipweerstand gemeten en beoordeeld. Met deze norm kan niet de duurzaamheid van de slipweerstand van beloopbare oppervlakken worden beoordeeld. Deze TRIBO-test is uitgevoerd bij één blankvlees- en één rosédeelnemer aan de vloeren die daar al enkele jaren in gebruik waren.

Via de afsluitende enquête zijn naar de ervaringen van de kalverhouders gevraagd, zowel t.a.v. de beloopbaarheid voor de kalveren als voor de dierverzorgers/kalverhouders zelf.

\section{Waarnemingen stalklimaat}

Het stalklimaat is over de volledige mestperiode per afdeling vastgelegd m.b.v. dataloggers die temperatuur $(T)$ en relatieve luchtvochtigheid (RV) met een ingestelde frequentie wegschrijven op een intern geheugen.

\section{Waarnemingen demoafdelingen}

Naast de basisproef zoals schematisch weergegeven in tabel 9. zijn er nog enkele aanvullende factoren in het onderzoek opgenomen. Dit zijn 'sexe' (i.c. vaarskalveren) en de ICE vloer uitgevoerd met zogenaamde kleppen t.b.v. emissiereductie. Beide factoren zijn ter oriëntatie elk op twee bedrijven belegd. Voor de vaarskalveren zijn dit twee blankvleesbedrijven. De demoafdeling met de ICE vloer met flappen lag op beide typen bedrijven. De waarnemingen m.b.t. de ICE vloer met kleppen richt zich alleen op de mestdoorlaatbaarheid (a) van de vloer en bevuiling (b) van de kalveren.

(a) Mestdoorlaatbaarheid

Rond 10 weken na opzet is per afdeling de vloer van 10 hokken visueel beoordeeld. Gekeken werd naar het percentage van de spleten die door mest dichtgeslibd zijn. 
(b) Bevuiling kalveren

Bevuiling is beoordeeld conform het protocol bevuiling kalveren (bijlage 7).

\section{Ammoniak- en geuremissiemetingen}

Eén van de nevendoelen van het project was om ammoniak- en geuremissiemetingen uit te voeren op basis vanwaar een officiële emissiefactor kan worden vastgesteld. Dit onderzoek is uitgevoerd op twee vleeskalverbedrijven (in Ede en Kootwijkerbroek) volgens de control-case opzet. Op ieder bedrijf zijn 4 afdelingen ingericht voor het onderzoek. De afdelingen werden mechanisch geventileerd. De afdelingen binnen een bedrijf verschilden alleen van elkaar in de vloeruitvoering van de kalverhokken. De volgende vloervarianten zijn onderzocht:

- Houten roostervloer (ca $80 \mathrm{~mm}$ balkbreedte en ca $30 \mathrm{~mm}$ spleetbreedte): dit is de referentie afdeling

- ICE roostervloer (ca $130 \mathrm{~mm}$ balkbreedte, uitgevoerd met een bolle indrukbare toplaag, en 29 $\mathrm{mm}$ spleetbreedte)

- Easyfix kalverrooster (ca $120 \mathrm{~mm}$ balkbreedte, uitgevoerd met een bolle rubber mat, en een speetbreedte van ca $30 \mathrm{~mm}$ )

- ICE roostervloer met klepjes (ca $130 \mathrm{~mm}$ balkbreedte, uitgevoerd met een bolle indrukbare toplaag, en ca $29 \mathrm{~mm}$ spleetbreedte) met afdichtende klepjes in de mestspleten.

De metingen zijn uitgevoerd conform het Meetprotocol 2013 (Ogink e.a., 2013) en het stalmanagement volgens de Landbouwkundige randvoorwaarden voor vleeskalveren behorende bij dit meetprotocol. Zo werd all-in - all out toegepast waarbij de betrokken afdelingen per bedrijf gelijktijdig worden gevuld. Het management en de verzorging van de kalveren was in alle afdelingen gelijk.

De metingen vonden plaats in de periode maart 2014 tot en met mei 2015.

In die periode werden op ieder bedrijf 6 meetseries uitgevoerd, verdeeld over het jaar en de groeicyclus van de kalveren. Een meetserie bestond uit 24 uurs ammoniakmetingen (nat-chemisch) van de in- en uitgaande lucht in elk van de afdelingen, olfactometrische geurmetingen (op basis van een 2 uurs luchtmonster door middel van de longzakmethode) door een gecertificeerd geurpanel, en continue registratie van het werkelijke ventilatiedebiet, de stal- en buitentemperatuur en de relatieve luchtvochtigheid.

Landbouwkundige gegevens en technische resultaten zijn gedurende de gehele meetperiode gemonitord.

Een uitgebreide en volledige weergave van het emissieonderzoek is terug te vinden in J. Mosquera, T. van Hattum, G.M. Nijeboer, J.M.G. Hol, H.J.C. van Dooren, S. Bokma (2016). Effect of floor type on the ammonia and odour emission from veal calves housing. Wageningen Livestock Research Report 980.

\section{Economische evaluatie}

Op basis van de onderzoeksresultaten is een bedrijfseconomische analyse en evaluatie uitgevoerd waarin de gemiddelde investerings- en jaarkosten van de onderzochte vloeren zijn berekend zowel in geval van nieuwbouw als verbouw. Omdat de zachte vloeren in het project maar een paar jaar in gebruik zijn geweest, hebben we geen harde cijfers over de levensduur. Er zijn daarom 3 scenario's doorgerekend; het "KWIN-scenario" dat uitgaat van de gebruikelijke (fiscale) afschrijvingstermijnen (10 jaar voor de zachte vloeren); het "gebruikers-scenario" op basis van een gemiddelde levensduur van de zachte vloeren van 7 jaar, en het "leverancier-scenario" uitgaande van een levensduur van de zachte vloeren van 20 jaar, welke door de producenten naar voren is gebracht. Daarnaast zijn de bedrijfseconomische gevolgen per dierplaats per jaar in beeld gebracht door de significant aantoonbare veranderingen in technische resultaten en arbeid (op basis van ervaringen kalverhouder) in de analyses te betrekken.

\section{Gebruikerservaringen kalverhouders}

$\mathrm{Na}$ afloop van de proef is een enquête uitgevoerd waarin de ervaringen van de kalverhouders over de vloeren zijn vastgelegd. 


\subsubsection{Analyse van data}

Alle gegevens zijn uitgedrukt op het niveau van de afdeling. Afdeling binnen ronde fungeerde als experimentele eenheid. Gegevens met betrekking tot bevuiling zijn eerst uitgedrukt als gemiddelde per hok; vervolgens is het gemiddelde berekend van alle hokken binnen eenzelfde afdeling. Een vergelijkbare benadering werd gevolgd voor de gedragswaarnemingen: de gegevens - i.c. frequenties van gedragingen - werden eerst uitgedrukt als aantal per kalf per hok. Als maat voor de activiteit van de kalveren is het totaal aantal activiteiten per kalf berekend als de som van het aantal keren vechten, het aantal keren dartelen, en het aantal keren bespringen. Het gemiddelde van de hokken binnen eenzelfde afdeling vormde het niveau van de afdeling. Daarnaast is, net als in de voorstudie, het aantal keren uitglijden per hok ook uitgedrukt als percentage van de som van het aantal keren uitglijden, het aantal keren vechten, het aantal keren dartelen, en het aantal keren bespringen. Dit percentage is een maat voor de waarschijnlijkheid dat activiteit (i.c. vechten, dartelen, en bespringen) gepaard gaat met uitglijden. Hoe lager dit percentage, hoe kleiner deze waarschijnlijkheid. De klinische en pathologische waarnemingen zijn per afdeling uitgedrukt als percentage van de onderzochte kalveren (of organen) met een bepaalde afwijking. Voor de technische resultaten, i.c. geslacht gewicht en het gebruik van antibiotica, waren gegevens beschikbaar van alle kalveren in de onderzochte afdelingen. Voor geslacht gewicht werden gemiddelden berekend per afdeling. De volgende variabelen werden gehanteerd per afdeling als afgeleiden van het gebruik van antibiotica: (i) gemiddeld aantal behandelingen per kalf, (ii) gemiddeld aantal dagen behandeld per kalf, (iii) aantal koppelbehandelingen, (iv) aantal dagen koppelbehandelingen, ( $v$ ) het aantal kalveren dat individueel werd behandeld, als \% van het totaal aantal kalveren in de koppel, (vi) het gemiddeld aantal behandelingen per individueel behandeld kalf, en (vii) het gemiddeld aantal dagen behandeld per individueel behandeld kalf.

Voor blankvlees- en rosékalveren zijn aparte statistische analyses uitgevoerd. Data met betrekking tot het klinisch en pathologisch onderzoek, bevuiling, geslacht gewicht en gebruik van antibiotica zijn statistisch geanalyseerd met een mixed model. Vloertype en Ronde zijn als fixed effecten in het model opgenomen. Bedrijf, de tweeweg interactie tussen Bedrijf en Ronde (Bedrijf $\times$ Ronde) en de drieweg interactie tussen Bedrijf, Ronde en Vloertype (Bedrijf $x$ Ronde $x$ Vloertype) zijn opgenomen als random termen. Het hoofdeffect van Vloertype werd getoetst tegen de interactie Bedrijf $x$ Vloertype. Gegevens over het gedrag zijn verzameld tijdens één ronde. Gedragsdata zijn geanalyseerd met een model met Vloertype als fixed effect en Bedrijf als random term. Bij de analyse van gegevens uitgedrukt als percentage had het mixed model de vorm van een gegeneraliseerd mixed model (GLMM), waarin een logit link was gespecificeerd, en waarin de variantiefunctie van de binomiale verdeling met een overdispersie parameter werd geïntroduceerd. In het geval van GLMM was de analyse gebaseerd op maximum pseudo Likelihood schatting. Paarsgewijze verschillen tussen vloertypen zijn getoetst met behulp van Fisher's Least Significant Difference (LSD) test.

Voor variabelen, uitgedrukt als percentage, met overwegend - in absolute termen - lage waarden (gemiddelden beduidend lager dan 5\%), inclusief relatief veel 'nullen' voor individuele ronden, convergeerde het model (GLMM) niet. Voor deze variabelen is gebruik gemaakt van een parametervrije toets, de Wilcoxon Matched Pairs Signed Rank Toets, waarbij binnen bedrijven paarsgewijs werd getoetst of het gemiddelde niveau op de referentievloer (gemiddeld over rondes) afwijkt van de gemiddelden op de alternatieve vloeren.

Op de gegevens verzameld op demoafdelingen en demobedrijven is alleen beschrijvende statistiek toegepast.

Alle resultaten staan in bijlage 8 weergegeven. In hoofdstuk 4.2 staan van de belangrijkste parameters de uitkomsten in grafieken weergegeven.

De uitkomsten van het emissieonderzoek zijn eveneens statistisch getoetst. Hierbij is onderzocht of de waargenomen effecten aantoonbaar verschillend waren van die van de referentievloeren.

De waarnemingen aan de vloeren en de gebruikerservaringen uit de enquêtes leenden zich niet voor nadere statistisch onderzoek. 


\subsection{Resultaten}

\subsubsection{Gedrag}

\section{Blankvlees kalveren}

Op 10 weken na opzetten was het effect van vloertype op de activiteit bijna significant $(P=0.053)$. Kalveren op de Easyfix vloer waren actiever dan kalveren op de referentievloer (zie figuur 17). Twee weken vóór slachten waren er geen significante verschillen meer in activiteit tussen de vloeren (figuur 17).
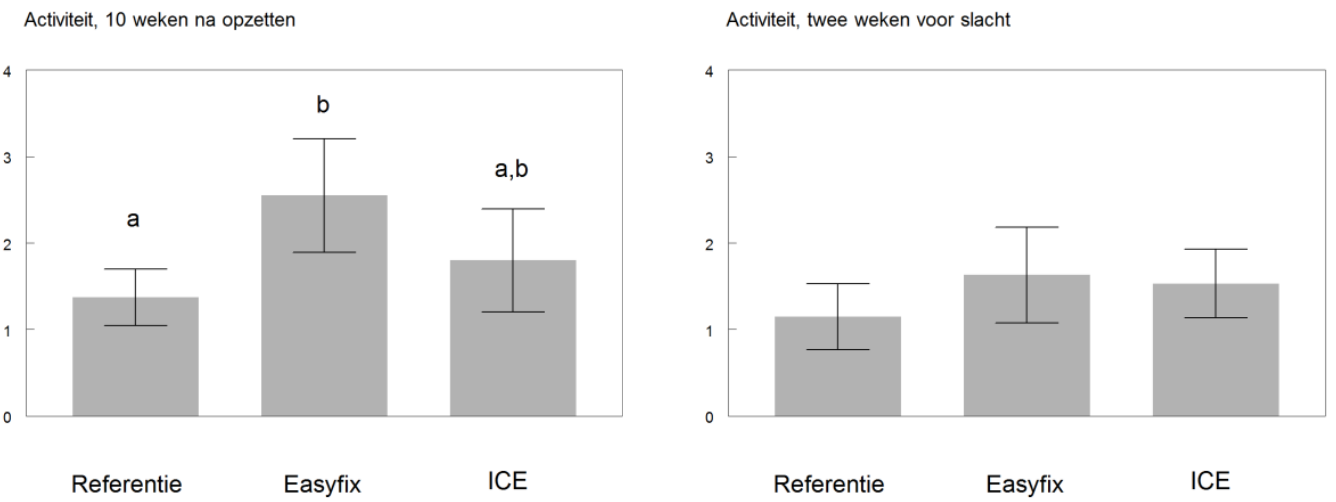

Figuur 17. Activiteit (aantal keren vechten plus dartelen plus bespringen per kalf; gemiddelde met SE = standard error of the mean, of standaardfout), 10 weken na opzet en twee weken voor slacht. $a, b$ Gemiddelden met verschillende letters verschillen significant van elkaar.

Vloertype had geen effect op de frequentie uitglijden op 10 weken na opzet. Twee weken voor de slacht was het effect van vloertype op de frequentie uitglijden significant $(P<0.05)$. De frequentie uitglijden was twee weken voor de slacht lager op de Easyfix vloer in vergelijking met de referentievloer en de ICE vloer. Het verschil tussen Easyfix en de referentie benaderde statistische significantie $(P=0.072)$; het verschil tussen ICE en de Easyfix was statistisch significant $(P<0.01)$, zie figuur 18.
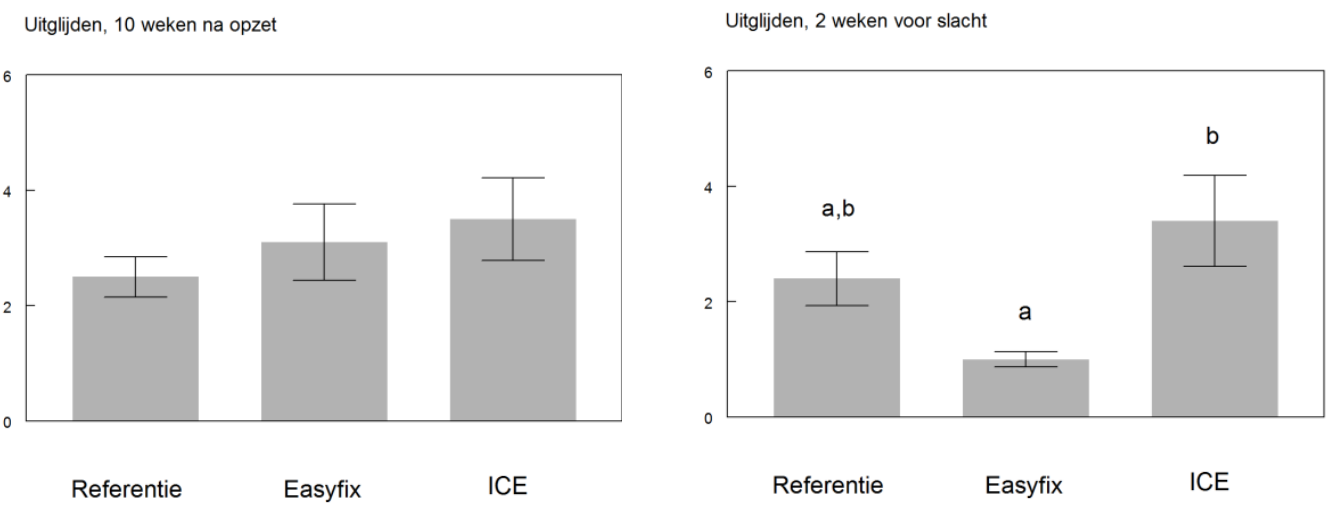

Figuur 18. Uitglijden (aantal keren per kalf; gemiddelde met SE), 10 weken na opzet en twee weken voor slacht. ${ }^{a, b}$ Gemiddelden met verschillende letters verschillen significant van elkaar.

Uitglijden als percentage van de totale activiteit (de som van uitglijden, vechten, dartelen en bespringen) werd twee weken voor de slacht significant beïnvloed door het vloertype (zie figuur 19). Op 10 weken na opzetten was dit effect niet aanwezig (figuur 19). 
Uitglijden, \% van totale activiteit, 10 weken na opzetten

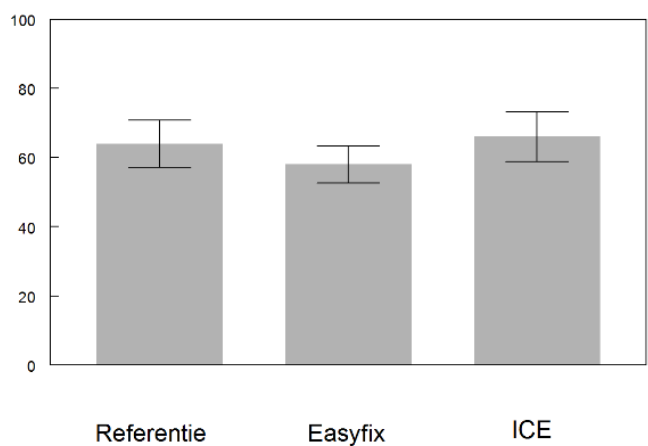

Uitglijden, \% van total activiteit, 2 weken voor slacht

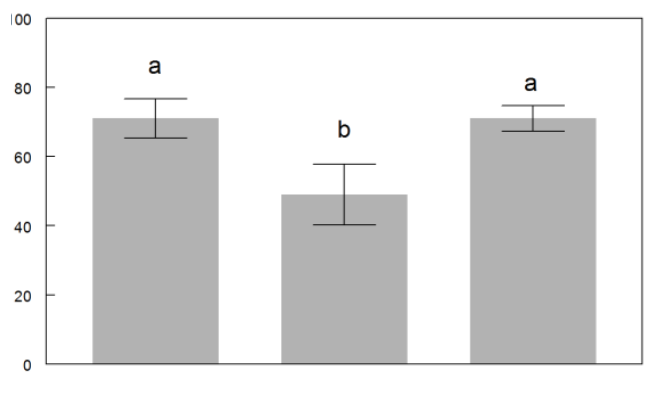

Referentie Easyfix

ICE

Figuur 19. Uitglijden (\% van de totale activiteit, gemiddelde met SE), 10 weken na opzet en twee weken voor slacht. ${ }^{a, b}$ Gemiddelden met verschillende letters verschillen significant van elkaar.

\section{Rosékalveren}

Bij rosékalveren had vloertype geen significant effect op de activiteit (de som van vechten, dartelen en bespringen), zie figuur 20 .

Activiteit, 8 weken na aanvang afmestfase

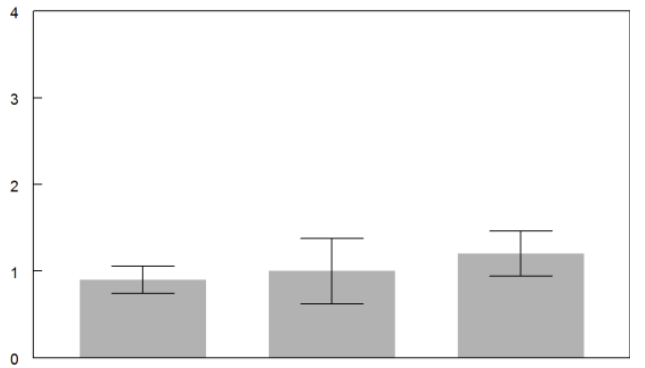

Referentie

Easyfix

ICE
Activiteit, 2 weken voor slacht

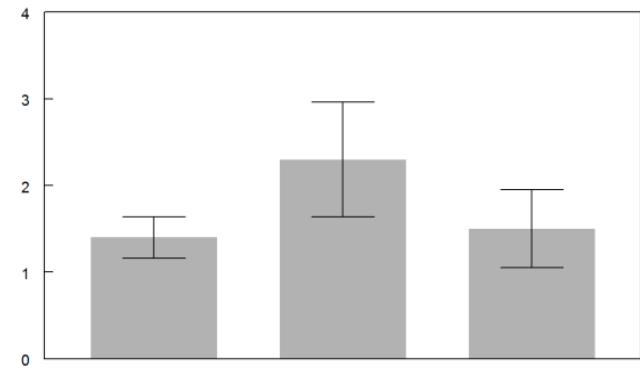

Referentie

Easyfix

ICE

Figuur 20. Activiteit (aantal keren vechten plus dartelen plus bespringen per kalf; gemiddelde met $S E), 8$ weken na aanvang afmestfase en twee weken voor slacht.

Acht weken na aanvang van de afmestfase had vloertype een bijna significant effect op de frequentie van uitglijden $(P<0.10)$. Op de ICE vloer werd de hoogste frequentie uitglijden gezien (zie figuur 21 ). Deze verschillen waren afwezig twee weken voor de slacht (figuur 21).

Uitglijden, 8 weken na na aanvang afmestfase

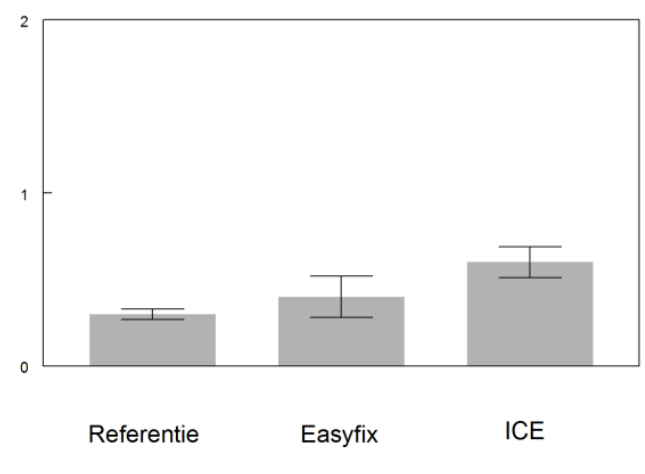

Uitglijden, 2 weken voor slacht

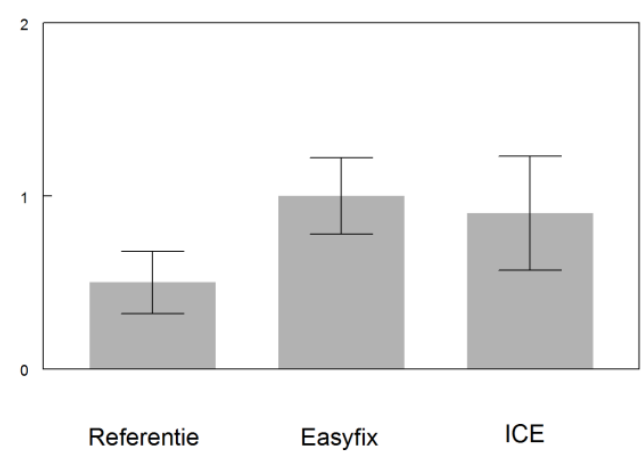

Figuur 21. Uitglijden (aantal keren per kalf; gemiddelde met SE), 8 weken na aanvang van de afmestfase en twee weken voor slacht. ${ }^{a, b}$ Gemiddelden met verschillende letters verschillen significant van elkaar.

Twee weken voor de slacht werd uitglijden als percentage van de totale activiteit (de som van uitglijden, vechten, dartelen en bespringen) bijna significant beïnvloed door het vloertype $(P<0.10)$. 
De waarschijnlijkheid dat activiteiten zoals vechten, dartelen, en bespringen gepaard gingen met uitglijden was voor de ICE vloer het grootst (zie figuur 22). Op 8 weken na aanvang van de afmestfase waren geen effecten van vloertype op uitglijden als percentage van de totale activiteit aanwezig.
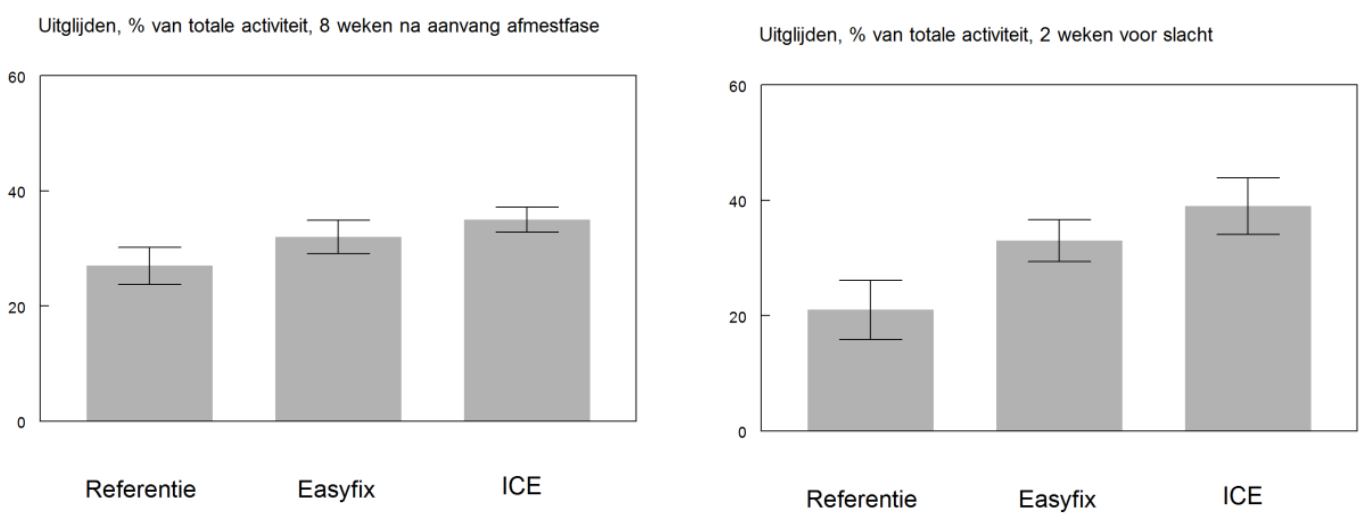

Figuur 22. Uitglijden (\% van de totale activiteit, gemiddelde met SE), 10 weken na opzet en twee weken voor slacht. ${ }^{a, b}$ Gemiddelden met verschillende letters verschillen significant van elkaar.

\subsubsection{Gezondheid}

Blankvleeskalveren

Met uitzondering van 'dikke knieën' (in de veterinair medische literatuur bekend als 'bursa' of 'verkregen slijmbeurs'), huidafwijkingen (beschadigingen plus tekenen van huidinfecties zoals schimmels) en natte vacht, was de prevalentie van de klinische aandoeningen gemiddeld genomen op beide leeftijden warop een inspectie werd uitgevoerd gemiddeld genomen kleiner dan $1 \%$ (en meestal < $0.5 \%$; zie bijlage 8 ).

voor alle gegevens). Op twee weken voor slachten had het vloertype een significant effect op de prevalentie van 'dikke knieën' $(P<0.01)$, met de hoogste prevalentie op de houten roostervloer (zie figuur 23). Op 10 weken na opzetten waren er nog geen verschillen in prevalentie van 'dikke knieën' tussen de vloeren waarneembaar (zie figuur 23).

Dikke knie (\%), 10 weken na opzetten

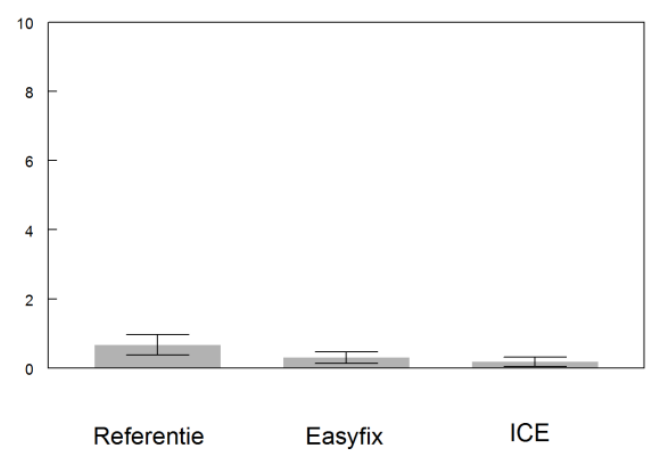

Dikke knie (\%), 2 weken voor slacht

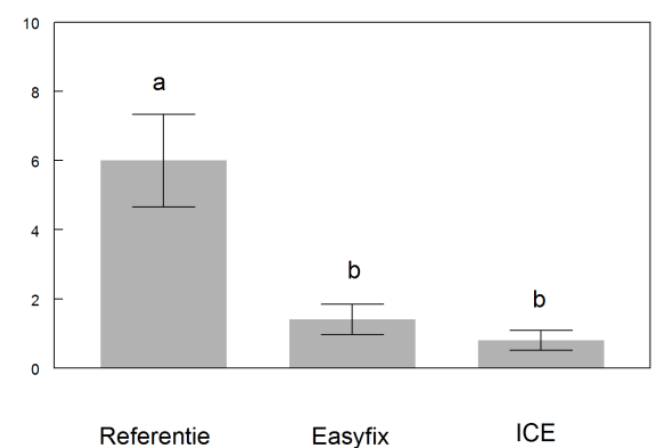

Figuur 23. Dikke knieën (gemiddeld \% met SE), 10 weken na opzet en twee weken voor slacht. ${ }^{a, b}$ Gemiddelden met verschillende letters verschillen significant van elkaar.

Vloertype had geen effect op de overige klinische afwijkingen.

\section{Rosékalveren}

Ook bij rosékalveren waren prevalenties van de meerderheid van de klinische afwijkingen op beide momenten waarop de inspecties plaatsvonden kleiner dan $1 \%$. Uitzondering hierop waren 'dikke knieën', huidafwijkingen en het percentage kalveren met een geschatte achterstand in conditie ten opzichte van de rest van de koppel van 15-30\% (zie bijlage 8 voor alle gegevens). Net als bij blankveeskalveren had vloertype op twee weken voor slachten een significant effect op de prevalentie van 'dikke knieën $(P<0.01)$; kalveren op de betonnen referentievloer lieten ten opzichte van Easyfix en ICE de hoogste prevalentie dikke knieën zien (zie figuur 24). Ook op 8 weken na aanvang van de 
afmestfase werd de prevalentie van dikke knieën door het vloertype beïnvloed, en werd onder kalveren op de referentievloer een significant hogere prevalentie dikke knieën gevonden dan onder kalveren op Easyfix en ICE ( $P<0.05$, Wilcoxon Matched Pairs Signed Rank Test; zie figuur 24).

Dikke knie (\%), 8 weken na aanvang afmest

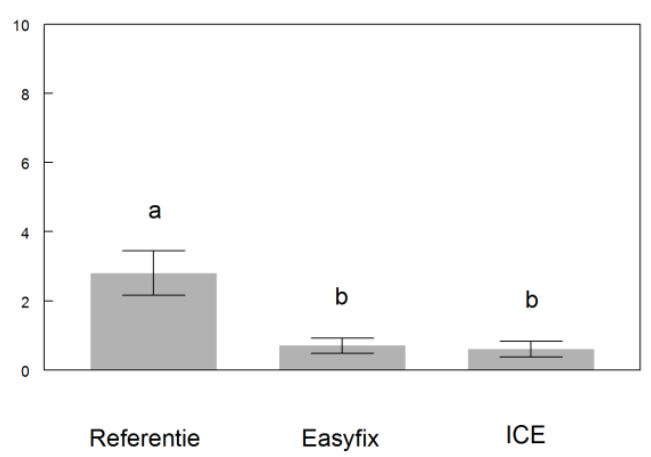

Dikke knie (\%), 2 weken voor slacht

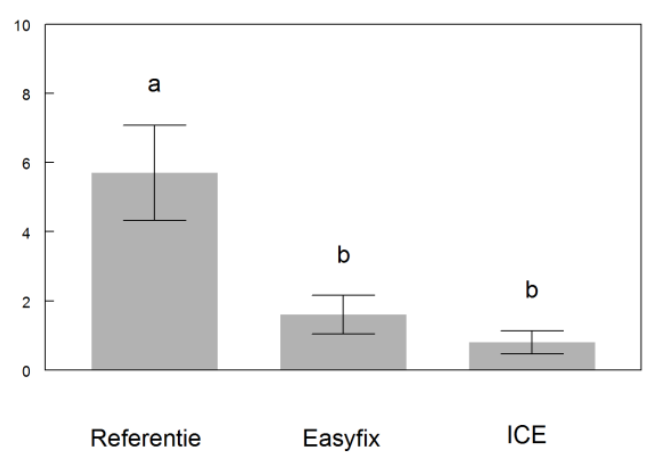

Figuur 24. Dikke knieën (gemiddeld \% met SE), 8 weken na aanvang van de afmestfase en twee weken voor slacht. ${ }^{a, b}$ Gemiddelden met verschillende letters verschillen significant van elkaar.

\subsubsection{Pathologie}

Blankvleeskalveren

Vloertype had geen effect op het vóórkomen van beschadigingen in de longen of op pleuritis (zie figuren 25 en 26).

Longen zonder beschadigingen (\%)

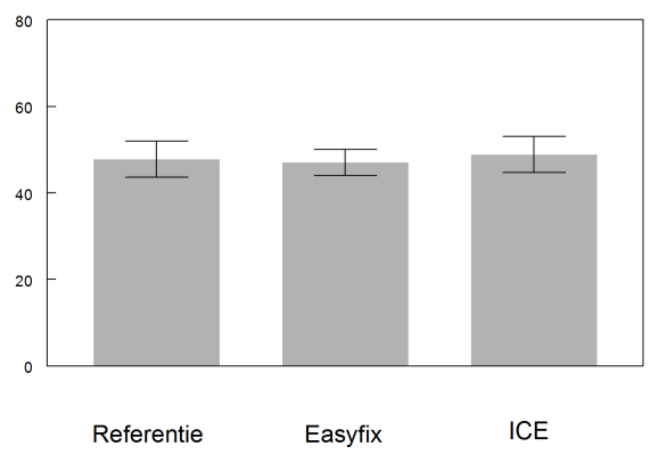

Longen ernstig aangetast (\%)

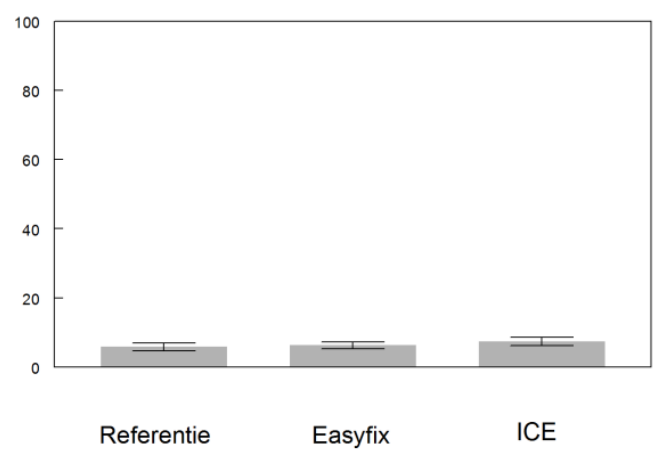

Figuur 25. Percentages (met SE) van longen zonder beschadigingen (score 0), en van ernstig aangetaste longen (score 3 ).

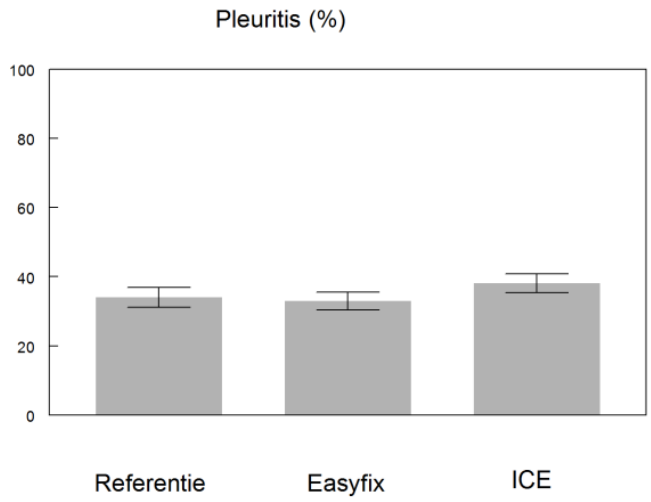

Figuur 26. Percentage (met SE) van pleuritis. 


\section{Rosékalveren}

Ook bij rosékalveren had vloertype geen effect op het vóórkomen van beschadigingen in de longen of op pleuritis (zie figuren 27 en 28 ).

Longen zonder beschadigingen (\%)

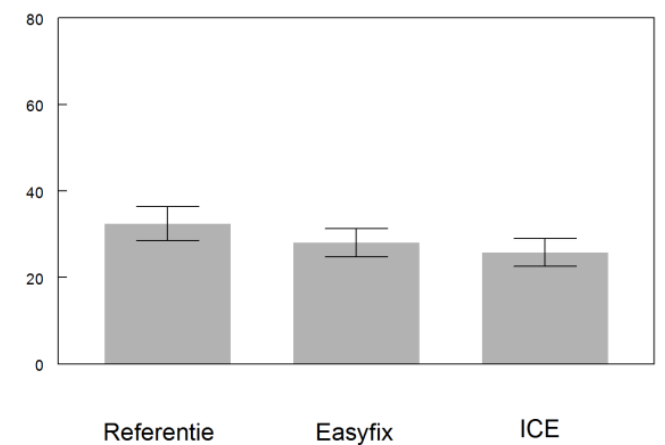

Longen ernstig aangetast (\%)

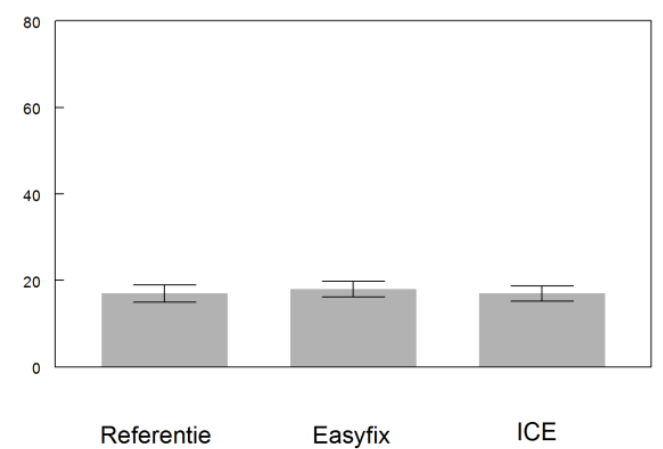

Figuur 27. Percentages (met SE) van longen zonder beschadigingen (score 0), en van ernstig aangetaste longen (score 3 ).

Pleuritis (\%)

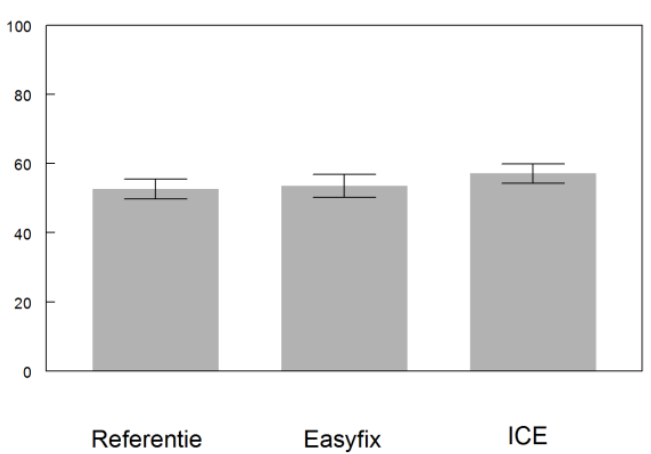

Figuur 28. Percentage (met SE) van pleuritis.

\subsubsection{Bevuiling en bezoedeling}

\section{Blankvleeskalveren}

In de eenlingboxen was het percentage kalveren met bevuiling aan de buik op alle drie de vloeren kleiner dan $0.5 \%$. In dit stadium van de ronde werd de gemiddelde bevuilingsscore van de kalveren significant beïnvloed door het vloertype $(P<0.01)$. In vergelijking met de referentievloer waren kalveren in eenlingboxen op Easyfix of ICE significant meer bevuild (zie figuur 29).

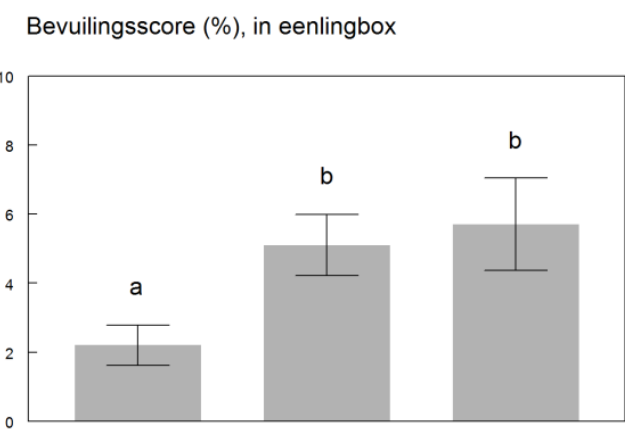

Referentie

$$
\text { Easyfix }
$$

ICE

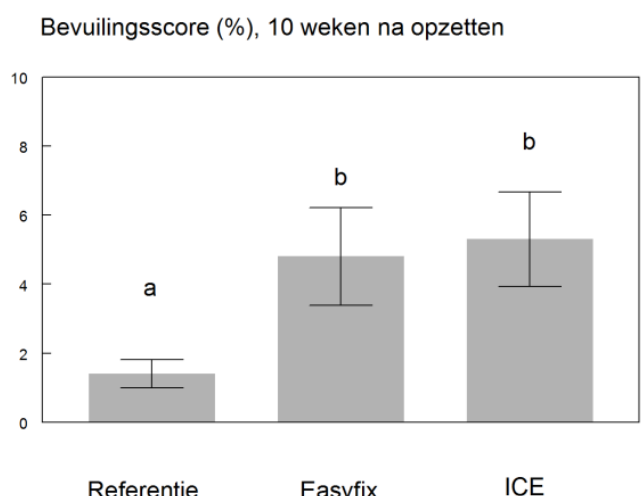

Figuur 29. Bevuilingsscores (gemiddelden met SE) van kalveren in de eenlingboxen en op 10 weken na opzetten. ${ }^{a, b}$ Gemiddelden met verschillende letters verschillen significant van elkaar. 
Op 10 weken na opzetten was het percentage kalveren met bevuiling aan de buik opnieuw relatief gering op alle drie de vloeren $(<1 \%)$. Vloertype had een significant effect op de gemiddelde totale bevuilingsscore $(P<0.05)$. Net als in de eenlingboxen waren kalveren op Easyfix en ICE ten opzichte van de referentievloer meer bevuild (zie figuur 29).

Twee weken voor de slacht had vloertype een significant effect op het percentage kalveren met bevuiling aan de buik $(P<0.05)$ en op de bevuilingsscore $(P<0.01)$. Het percentage kalveren met bevuiling aan de buik en de gemiddelde bevuilingsscore waren relatief gezien het laagst onder kalveren gehuisvest op de referentievloer ten opzichte van Easyfix en ICE (zie figuur 30).

Kalveren met bevuiling aan buik (\%), 2 weken voor slacht

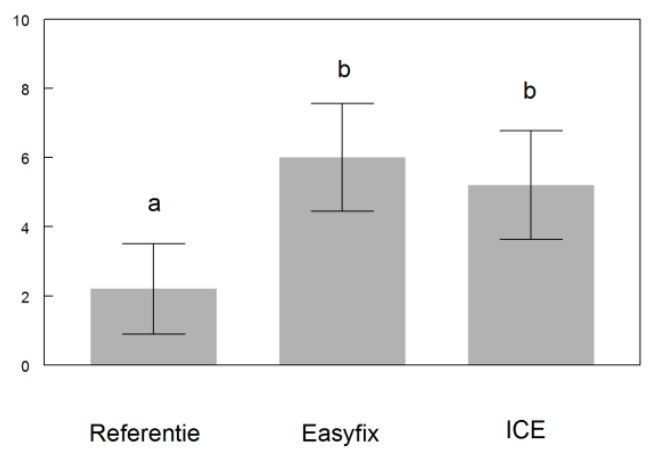

Bevuilingsscore (\%), 2 weken voor slacht

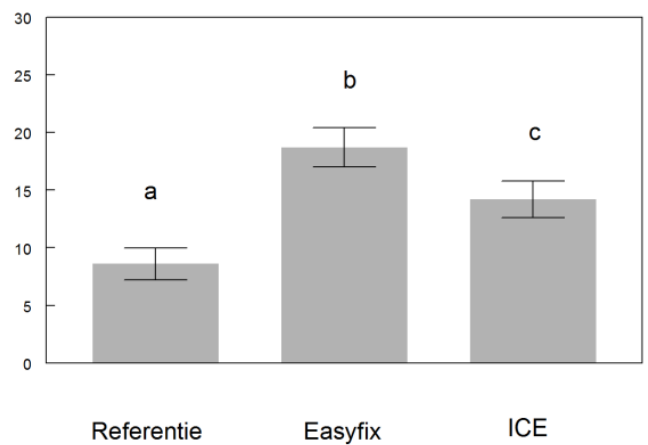

Figuur 30. Percentages kalveren met bevuiling aan de buik en bevuilingsscores (gemiddelden met $S E$ ) op 2 weken voor de slacht. ${ }^{a, b}$ Gemiddelden met verschillende letters verschillen significant van elkaar.

Op het slachthuis is bevuiling van kalveren na aankomst 'blind' beoordeeld door een kwaliteitsfunctionaris (die dus niet op de hoogte was van de achtergrond qua vloertype). Transporten werden zodanig georganiseerd dat kalveren van dezelfde vloer als groep bij elkaar op dezelfde vrachtauto zaten. In totaal is de bevuiling vastgelegd van 63 vrachtauto's, 21 per vloertype. De kalveren van in totaal 4 vrachtauto's werden als vuil beoordeeld (6\%), één met kalveren van de referentievloer, twee van Easyfix en één van ICE.

\section{Rosékalveren}

Op 8 weken na aanvang van de afmestfase had het vloertype een bijna significant effect op het percentage kalveren met bevuiling aan de buik $(P<0.10)$, en een significant effect op de bevuilingsscore $(P<0.05)$. In vergelijking met de referentievloer en ICE kwam bevuiling aan de buik kwam het minst voor op ICE (figuur 31). Op 8 weken na aanvang van de afmestfase was de algehele bevuilingsscore gemiddelde genomen het hoogst op Easyfix (figuur 31).

Kalveren met bevuiling aan buik (\%), 8 weken afmestfase

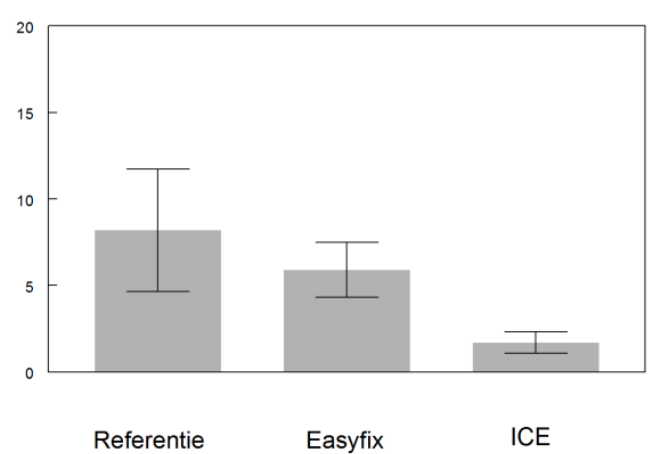

Bevuilingsscore (\%), 8 weken na aanvang afmestfase

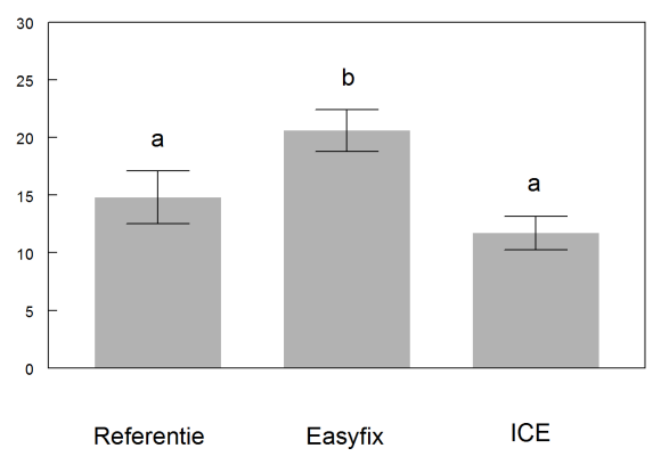

Figuur 31. Percentages kalveren met bevuiling aan de buik en bevuilingsscores (gemiddelden met SE) op 8 weken na aanvang van de afmestfase. ${ }^{a, b}$ Gemiddelden met verschillende letters verschillen significant van elkaar.

Twee weken voor de slacht werden het percentage kalveren met bevuiling aan de buik en de bevuilingsscore significant beïnvloed door het vloertype (respectievelijk $P<0.05$, en $P<0.01$ ). Ten 
opzichte van de andere twee vloeren waren kalveren op ICE het minst bevuild, zowel aan de buik, als in het algemeen in termen van de bevuilingsscore (zie figuur 32).

Kalveren met bevuiling aan buik (\%), 2 weken voor slacht

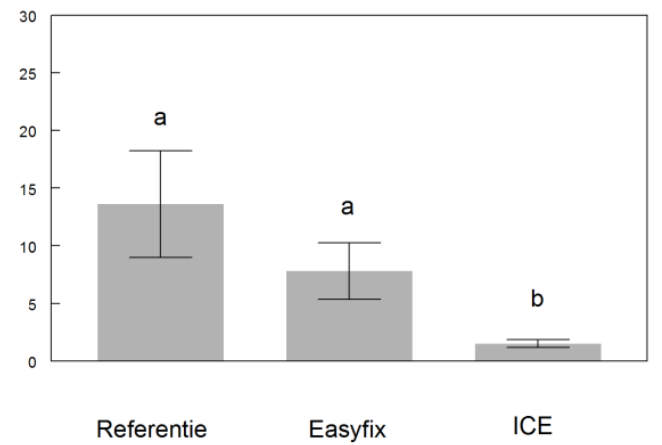

Bevuilingsscore (\%), 2 weken voor slachten

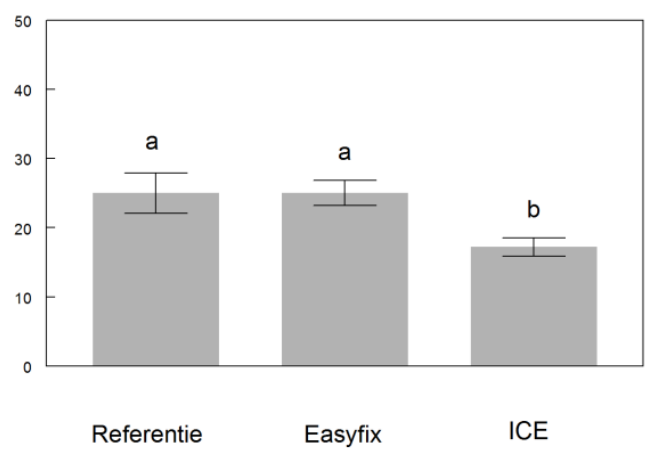

Figuur 32. Percentages kalveren met bevuiling aan de buik en bevuilingsscores (gemiddelden met SE) op 2 weken voor de slacht. ${ }^{a, b}$ Gemiddelden met verschillende letters verschillen significant van elkaar.

Op het slachthuis zijn gegevens vastgelegd over bevuiling van kalveren bij aankomst van in totaal 71 vrachtauto's, 23 met kalveren gehuisvest op de referentievloer, 24 met kalveren gehuisvest op Easyfix, en 24 met kalveren gehuisvest op ICE. De kalveren van in totaal 7 vrachtauto's werden als vuil beoordeeld $(10 \%)$, vier met kalveren van de referentievloer en drie met kalveren van Easyfix.

\subsubsection{Geslacht gewicht en voeropname}

Als cruciale indicator voor de groei is het geslachte gewicht geanalyseerd. Op basis van het gewicht bij opzetten is ook de groei per dag uitgerekend. Statistische analyse van de groei per dag gaf exact dezelfde uitkomsten als de analyse van het geslachte gewicht.

\section{Blankvleeskalveren}

Vloertype had geen effect op het geslachte gewicht (zie figuur 33). De kalveren op de referentievloer hadden een gemiddeld slachtgewicht van $149 \mathrm{~kg}$, de kalveren op de Easyfix vloer 148,6 kg en de kalveren op de ICE vloer 147,5 kg.

Geslacht gewicht $(\mathrm{kg})$

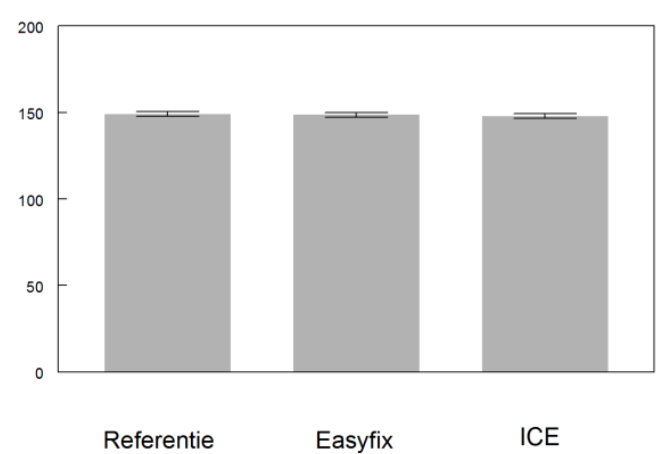

Figuur 33. Geslacht gewicht (gemiddelde met SE).

De gemiddeld droge stof opname per dier per dag, i.c. melkpoeder plus ruwvoer uitgedrukt in $\mathrm{kg}$ kalvermelkequivalenten (gemiddelde met SE) was bijna identiek voor de referentievloer, Easyfix en ICE, respectievelijk: 2,41 $\pm 0,063 ; 2,40 \pm 0,055$ en 2,39 $\pm 0,059$. Bij gelijke (karkas)groei verschilde voerefficiëntie tussen vloertypen niet. 


\section{Rosékalveren}

Het geslachte gewicht van rosékalveren werd niet beïnvloed door het vloertype (zie figuur 34). De kalveren op de referentievloer hadden een gemiddeld slachtgewicht van $178,1 \mathrm{~kg}$, de kalveren op de Easyfix vloer 179,5 kg en de kalveren op de ICE vloer 179,4 kg.

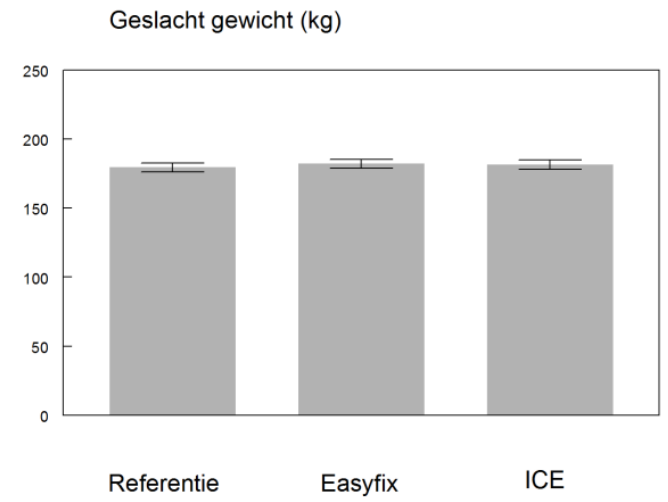

Figuur 34. Geslacht gewicht (gemiddelde met SE).

Vloertype had geen effect op de voederconversie (kVevi). Voederconversies per dier per dag, uitgedrukt als opgenomen VEVI per $\mathrm{kg}$ groei (gemiddelde met SE), waren 5,0 $\pm 0,22 ; 5,5 \pm 0,32$ en $5,1 \pm 0,21$ voor, respectievelijk, de referentievloer Easyfix en ICE.

\subsubsection{Gebruik antibiotica en uitval}

Blankvleeskalveren

Vloertype had geen effect op de uitval (zie figuur 35).

Uitval (\%)

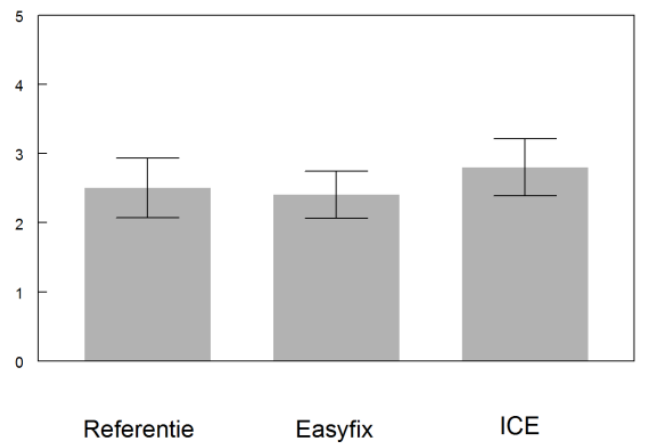

Figuur 35. Uitval (gemiddelde percentages met SE).

Ook het gebruik van antibiotica vanaf opzetten tot slacht werd niet door het vloertype beïnvloed (zie tabel 10). 
Tabel 10. Variabelen met betrekking tot gebruik van antibiotica (gemiddelde met SE).

\begin{tabular}{|c|c|c|c|c|c|c|}
\hline \multirow[b]{3}{*}{ Variabele } & \multicolumn{6}{|c|}{ Vloertype } \\
\hline & \multicolumn{2}{|c|}{ Referentie } & \multicolumn{2}{|c|}{ Easyfix } & \multicolumn{2}{|c|}{ ICE } \\
\hline & Gem. ${ }^{1}$ & SE & Gem. & SE & Gem. & SE \\
\hline Gem. aantal individuele behandelingen per kalf & 0.6 & 0.08 & 0.7 & 0.09 & 0.7 & 0.10 \\
\hline Gem. aantal individuele behandeldagen per kalf & 1.1 & 0.13 & 1.2 & 0.18 & 1.2 & 0.14 \\
\hline Aantal koppelbehandelingen met antibiotica & 4.5 & 0.43 & 4.6 & 0.43 & 4.5 & 0.43 \\
\hline Aantal dagen koppelbehandeling met antibiotica & 22.2 & 2.11 & 22.4 & 2.15 & 22.0 & 2.12 \\
\hline Aantal kalveren individueel behandeld (\% van koppel) & 30 & 2.6 & 31 & 2.9 & 31 & 2.8 \\
\hline Gem. aantal behandelingen per indiv. behan. kalf² & 1.7 & 0.23 & 1.9 & 0.17 & 2.0 & 0.32 \\
\hline Gem. aantal behandeldagen per indiv. behan. kalf ${ }^{2}$ & 2.4 & 0.27 & 2.6 & 0.28 & 2.7 & 0.36 \\
\hline
\end{tabular}

${ }^{1}$ Gem. = Gemiddelde

2indiv. behan. kalf $=$ individueel met antibiotica behandeld kalf

\section{Rosékalveren}

Bij rosékalveren was er een tendens dat de uitval onder kalveren op Easyfix en ICE iets lager was dan de uitval onder kalveren op de betonnen referentievloer $(P<0.10$ voor zowel het verschil tussen Easyfix en de referentievloer als het verschil tussen ICE en de referentievloer, Wilcoxon

Uitval (\%)

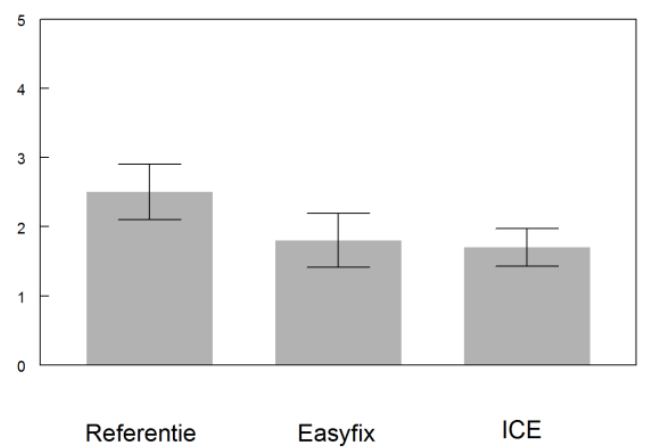

Figuur 36. Uitval (gemiddelde percentages met SE).

Het vloertype had bij rosékalveren geen effect op het gebruik van antibiotica tijdens de afmestfase (zie tabel 11).

Tabel 11. Variabelen met betrekking tot gebruik van antibiotica (gemiddelde met SE).

\begin{tabular}{lccccccc} 
& \multicolumn{3}{c}{ Referentie } & \multicolumn{3}{c}{ Easyfix } & \multicolumn{2}{c}{ ICE } \\
\hline Variabele & Gem. ${ }^{1}$ & SE & Gem. & SE & Gem. & SE \\
\hline Gem. aantal individuele behandelingen per kalf & 0.1 & 0.03 & 0.1 & 0.01 & 0.1 & 0.01 \\
\hline Gem. aantal individuele behandeldagen per kalf & 0.1 & 0.05 & 0.1 & 0.03 & 0.1 & 0.03 \\
\hline Aantal koppelbehandelingen met antibiotica & 0 & 0 & 0 & 0 & 0 & 0 \\
\hline Aantal dagen koppelbehandeling met antibiotica & 0 & 0 & 0 & 0 & 0 & 0 \\
\hline Aantal kalveren individueel behandeld (\% van koppel) & 7 & 2.1 & 6 & 1.1 & 6 & 1.0 \\
\hline Gem. aantal behandelingen per indiv. behan. kalf & & 1.2 & 0.06 & 1.2 & 0.05 & 1.2 & 0.05 \\
\hline Gem. aantal behandeldagen per indiv. behan. kalf & & 1.5 & 0.17 & 1.8 & 0.26 & 1.7 & 0.18 \\
\hline
\end{tabular}

${ }^{1} \mathrm{Gem}$. = Gemiddelde

${ }^{2}$ indiv. behan. kalf $=$ individueel met antibiotica behandeld kalf 


\subsubsection{Waarnemingen vloeren}

De alternatieve vloeren zijn op de vleeskalverbedrijven op nieuwe houten roosters aangebracht bij de rosé bedrijven zijn ze in de meeste gevallen op de bestaande betonnen roostervloer gelegd. Om aan de eis van een minimale roosterspleet te voldoen zijn op een aantal bedrijven de spleten van de betonroosters gefreesd tot de minimale breedte van $38 \mathrm{~mm}$. In tabel 12 staan de verschillende afmetingen van zowel de roostervloer als de toplaag vermeld.

Tabel 12. Afmetingen ondervloeren en toplagen (afmetingen in $\mathrm{mm}$ ).

\begin{tabular}{|c|c|c|c|c|}
\hline & \multicolumn{2}{|c|}{ Ondervloer } & \multicolumn{2}{|c|}{ Toplaag } \\
\hline \multicolumn{5}{|c|}{ Easy fix } \\
\hline Hout & 110 & 40 & 120 & 30 \\
\hline Beton & $119-130$ & 38 & $129-140$ & 28 \\
\hline Beton & $119-130$ & 38 & $127-138$ & 30 \\
\hline
\end{tabular}

$\mathrm{Na}$ een jaar en aan het einde van het onderzoek zijn de bedrijven bezocht en de vloeren beoordeeld in schone toestand, d.w.z. nadat de afdelingen leeg een gereinigd waren. Ook zijn er toen metingen verricht om eventuele veranderingen van de vloer vast te leggen.

\section{Easyfix}

Over het algemeen ziet de rubbertoplaag er na enkele jaren jaar gebruik goed uit. Een probleem op een aantal (m.n. blankvlees-) bedrijven was dat er soms stroken loskwamen. Dit is effectief verholpen door de stroken op de ondervloer vast te schroeven. Het rubber van de matten loopt wel iets uit, na twee jaar in gebruik te zijn geweest. De stroken lopen met name aan de buitenzijde van de duo-mat wat uit. Er zijn een aantal beschadigingen geconstateerd aan de zijkant van de rubberstroken. Het "rokje" dat het onderliggende rooster afdekt aan de zijkant vertoont op een aantal plaatsen scheurtjes of is gedeeltelijk afgescheurd. Ook zijn incidenteel slijtage plekken aan de bovenzijde van de toplaag en scheuren geconstateerd. De genoemde beschadigingen waren niet van dien aard dat de matten hierdoor hun functionaliteit verliezen of binnen de garantievoorwaarden vervangen konden worden. Er zijn geen beschadigingen geconstateerd als gevolg van het periodiek reinigen met behulp van een hogedruk reiniger.

Op één bedrijf is aan het einde van de proef een klein deel van de toplagen verwijderd. Onder de Easyfix mat was het onderliggende rooster nat en was mest aanwezig (zie bijlage 9). Mogelijk kan dit worden verholpen door de "rokjes" aan de zijkant langer te maken.

\section{ICE}

De ICE toplagen zien er na 2 - 3 jaar gebruik prima uit; er zijn geen beschadigingen geconstateerd aan de vloer die door het verblijf van de kalveren zijn ontstaan. Wel is een aantal mechanische beschadigingen geconstateerd die ontstaan zijn als gevolg van het schoonspuiten met de hogedrukreiniger. De toplaag bij de ICE vloer loopt bij de rosé bedrijven gemiddeld $1 \mathrm{~mm}$ meer uit dan op de bedrijven met blankvleeskalveren.

Bij verwijdering van de ICE toplaag was het onderliggende rooster na 2 jaar nog droog en schoon. (zie bijlage 9).

\section{ICE demo met klepjes:}

De demo met ICE vloer met klepjes is geen overwegend succes gebleken. De deelnemende bedrijven hadden hiermee wisselende ervaring, over het algemeen minder positief dan de vergelijkbare ICEvloer zonder kleppen. De klep vormt een extra barrière in de mestspleet. De mestspleten lopen sneller vol met mest en voerresten. Dit lijkt meer te spelen op de bedrijven met rosékalveren. Op deze bedrijven wordt snijmais en brok gevoerd. De hokken en kalveren worden daardoor vuil en smerig. Hetzelfde rantsoen werd ook gevoerd aan de kalveren op de ICE vloer zonder klepjes op hetzelfde bedrijf en daar raakten de spleten niet verstopt. 


\section{Stroefheidstest met behulp van TRIBO-meter}

Aan het eind van het proef zijn in samenwerking met het ingenieursbureau Aveco de Bondt dynamische stroefheidsmetingen met behulp van de TRIBO-meter uitgevoerd aan de vloeren op één blankvlees- en één rosé bedrijf (bedrijven $\mathrm{E}$ resp. $\mathrm{O}$ ). De metingen zijn uitgevoerd volgens de norm NEN 7909:2015 "Slipweerstand van beloopbare oppervlakken - Eis en bepalingsmethode". Hierbij is uitgegaan van een gebruikssituatie onder natte omstandigheden omdat dit de situatie in kalverstallen, waar de roosters met urine en mest zijn bevuild, het beste representeert. De norm hanteert als ondergrenswaarde voor verantwoord humaan gebruik (voldoende stroefheid) 0,40. En bij gebruik met snelle bewegingsveranderingen een ondergrens van 0,45 .

In tabel 13 zijn de uitkomsten van alle individuele metingen weergegeven. De toetsing aan de norm in tabel 14 samengevat. Voor het volledige rapport verwijzen we naar bijlage 10.

De belangrijkste uitkomsten zijn dat:

- $\quad$ de indrukbare vloeren zich laten rangschikken tussen de hardhouten roostervloer (laagste slipweerstand) en het betonrooster (hoogste weerstand);

- $\quad$ er tussen bedrijven soms vrij grote verschillen te zien zijn;

- $\quad$ het hardhouten rooster en soms de Easyfix-mat niet aan de NEN-norm voor humaan gebruik voldoen.

Verder moet opgemerkt worden dat roostervloeren nog aanvullend grip geven door middel van de roosterspleten. Dit wordt niet zichtbaar in de TRIBO-metingen omdat deze in de lengterichting van de roosterbalken worden uitgevoerd. De Tribo-uitkomsten vertegenwoordigen derhalve niet de gemiddelde stroefheid van de roosters, maar de laagste stroefheidswaarden. 
Tabel 13. Resultaten TRIBO-metingen natte condities.

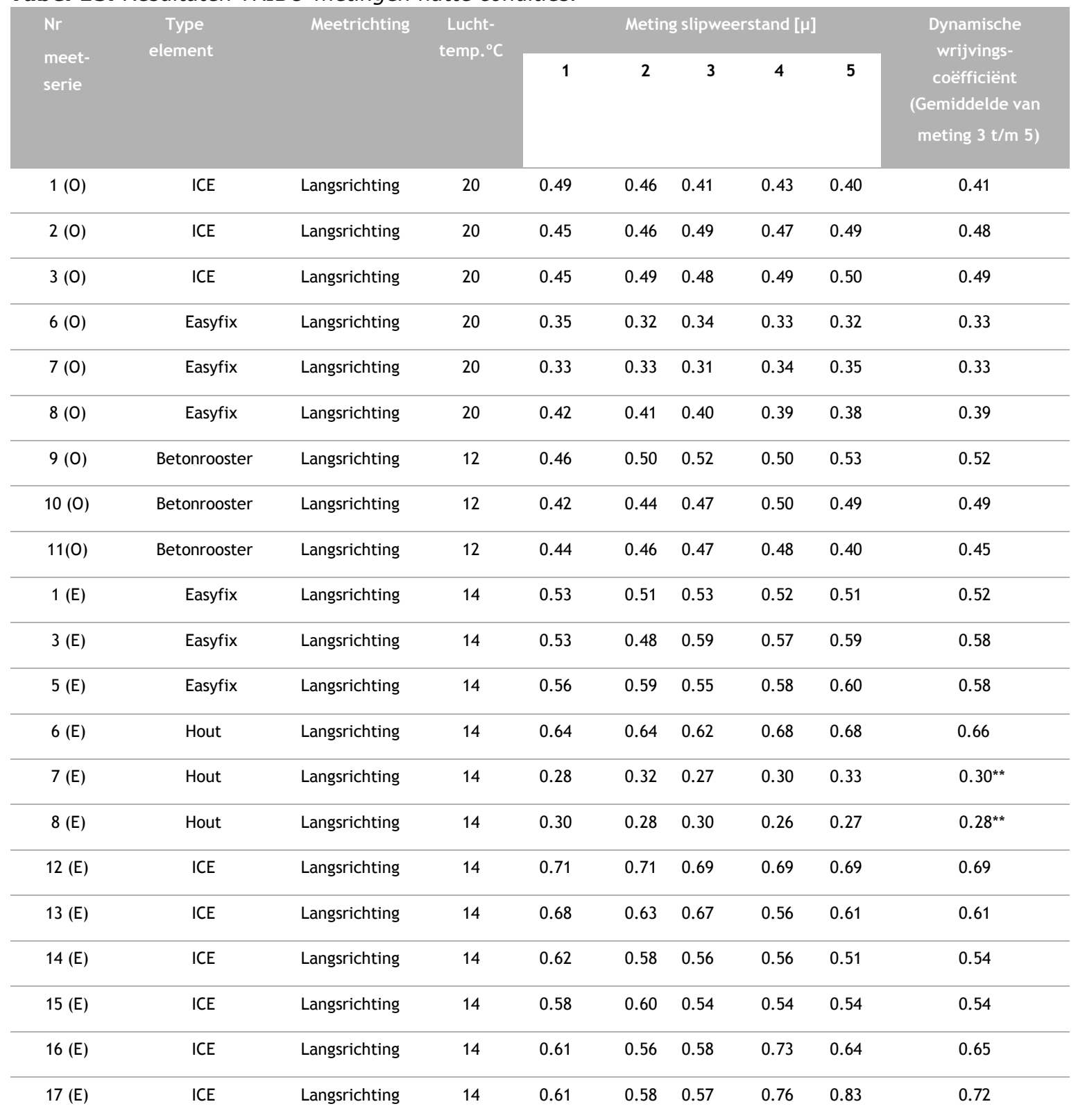

* Met nerf mee gemeten onder droge condities

** Met nerf mee gemeten onder natte condities

Tabel 14. Toetsing TRIBO-metingen aan eis (natte condities).

\begin{tabular}{|c|c|c|c|c|c|}
\hline Meetserie & $\begin{array}{c}\text { Type } \\
\text { element }\end{array}$ & $\begin{array}{l}\text { Maatgevende } \\
\text { richting }\end{array}$ & $\begin{array}{c}\text { Maatgevende dynamische } \\
\text { wrijvingscoëfficiënt }[\mu]\end{array}$ & $\begin{array}{l}\text { Voldoende stroef } \\
\text { volgens eis } \\
\text { Natte } \\
\text { toepassing }\end{array}$ & $\begin{array}{l}\text { Voldoet } \\
\text { aan eis } \\
\text { JA/NEE }\end{array}$ \\
\hline 1, 2, $3(0)$ & ICE & Langsrichting & 0.41 & $\mu \geq 0.40$ & JA \\
\hline $6,7,8(0)$ & Easyfix & Langsrichting & 0.33 & $\mu \geq 0.40$ & NEE \\
\hline$, 10,11(0)$ & Betonrooster & Langsrichting & 0.45 & $\mu \geq 0.40$ & JA \\
\hline $1,3,5(E)$ & Easyfix & Langsrichting & 0.52 & $\mu \geq 0.40$ & JA \\
\hline 7 en $8(E)$ & Hout & Langsrichting & 0.28 & $\mu \geq 0.40$ & NEE \\
\hline $\mathrm{t} / \mathrm{m} 17(\mathrm{E})$ & ICE & Langsrichting & 0.54 & $\mu \geq 0.40$ & JA \\
\hline
\end{tabular}




\subsubsection{Stalklimaat}

Met behulp van klimaatsensoren is in elke afdeling gedurende elke ronde gelijktijdig op een tweetal momenten (8 (blank) of 10 (rosé) weken na opzet en 2 weken voor slacht) gedurende een week elke 10 minuten de binnen en buitentemperatuur, en de relatieve luchtvochtigheid binnen en buiten vastgelegd. Per ronde zijn voor elk van deze variabelen gemiddelden uitgerekend. Vervolgens zijn waarden berekend voor het verschil tussen binnen- en buitentemperatuur en de relatie luchtvochtigheid binnen en buiten door de gemiddelden buiten af te trekken van de gemiddelden binnen. Op deze verschillen is variantie-analyse toegepast om te kijken of het vloertype een effect heeft op het stalklimaat binnen ten opzichte van de klimaatomstandigheden buiten. Voor geen van deze variabelen is een significant effect van vloertype gevonden.

\subsubsection{Waarnemingen demoafdelingen}

Aan de waarnemingen op de demoafdelingen kon geen statistiek toegepast worden, maar kalveren op de alternatieve vloeren waren gemiddeld vuiler dan de kalveren op de demo-afdelingen. De gemiddelden van alle waarnemingen aan de demoafdelingen staan in bijlage 11.

\subsubsection{Emissiemetingen}

De uitkomsten van het emissieonderzoek zijn uitvoerig beschreven in het rapport "Effect of floor type on the ammonia and odour emission from veal calves housing" (Mosquera et al., 2016). In deze paragraaf zijn de belangrijkste bevindingen samengevat.

Het onderzoek heeft plaatsgevonden op 2 blankvleesbedrijven met elk 4 identieke afdelingen volgens het case-control principe. De metingen zijn evenredig verdeeld over het jaar en het groeitraject van de blankvleeskalveren uitgevoerd. Het onderzoek is derhalve niet opgezet om absolute emissiefactoren vast te stellen, maar om betrouwbare uitspraken te kunnen doen over de relatieve verandering van de emissie ten opzichte van de referentie.

Tabel 15 geeft de gemiddelde ammoniakemissie weer van de vloeren (uitgedrukt in kg per dierplaats per jaar) op basis van de zes 24-uursmetingen dit op elk bedrijf zijn uitgevoerd. Bij het bepalen van deze emissie-cijfers is rekening gehouden met een leegstandscorrectie van $7 \%$. Het beeld dat beide bedrijven laten zien is heel consistent, De ICE vloer met kleppen vormt een uitzondering en laat meer variantie zien.

Over het geheel genomen was de ammoniakemissie van de ICE met kleppen significant lager dan die van de andere onderzochte vloeren $(P<0,05)$. De waargenomen verschillen tussen de ICE, Easyfix en hardhouten referentievloer waren niet significant $(P>0,10)$.

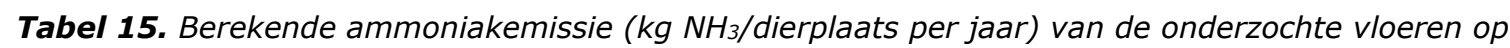
beide blankvleesbedrijven.

\begin{tabular}{cccc} 
Vloertype & & Ammoniak emissie $[\mathrm{kg} /$ dierplaats $/ \mathrm{j}]$ & Gemiddeld (n=2) \\
& Bedrijf 1 & Bedrijf 2 & 3.9 \\
\hline ICE met kleppen & 3.4 & 4.3 & 4.7 \\
\hline ICE & 4.7 & 4.7 & 5.2 \\
\hline Easyfix & 5.1 & 5.2 & 5.1 \\
\hline Standaard hardhouten rooster & 4.9 & 5.1 & 5.0 \\
\hline
\end{tabular}

In tabel 16 zijn de reductiepercentages weergegeven waarin de gemiddeld gemeten ammoniakemissie per vloertype afwijkt van dat van de referentievloer. Enerzijds binnen de afzonderlijke bedrijven, anderzijds voor het totaal van alle metingen. 
Tabel 16. Vastgestelde ammoniakemissiereductie (in \%) van de onderzochte vloeren ten opzichte van de hardhouten referentievloer op beide blankvleesbedrijven.

\begin{tabular}{cccr} 
Vloertype & \multicolumn{3}{c}{ Ammoniakreductiepercentage [\% van de referentie vloer] } \\
& \multicolumn{3}{c}{ Gemiddelde \pm standard afwijking } \\
\hline ICE met kleppen & Bedrijf 1(n=6) & Bedrijf 2(n=6) & Gemiddeld \\
\hline ICE & $29.4 \pm 8.4$ & $15.3 \pm 6.5$ & $22.3 \pm 5.5$ \\
\hline Easyfix & $4.1 \pm 4.0$ & $6.9 \pm 3.6$ & $5.5 \pm 2.6$ \\
\hline
\end{tabular}

De ICE-vloer met kleppen laat een gemiddeld ruim $22 \%$ lagere ammoniakuitstoot zien dan de houten referentievloer. Ook hier zien we een wat grotere spreiding, vooral binnen bedrijven ten opzichte van de andere vloeren. De Easyfix en ICE zonder kleppen verschillen niet veel van de referentievloer. Zij dragen niet bij aan een vermindering van de ammoniakuitstoot.

Naast ammoniak, is ook de geuremissie onderzocht. Hiertoe is op de ammoniakmeetdagen uit de ventilatiekoker van iedere afdeling een geurverzamelmonster genomen gedurende 2 uur. Deze luchtmonsters zijn olfactometrisch, met behulp van een geurpanel in het lab, beoordeeld om daarin de geurdrempel te bepalen. Tabel 17 geeft de hieruit berekende gemiddelde geuremissiewaarden (uitgedrukt in odourunits per seconde (OUe/s) per dierplaats) van de verschillende kalvervloeren weer.

Tabel 17. Gemeten geuremissie (OUe/s per dierplaats) van de onderzochte vloeren op beide blankvleesbedrijven.

\begin{tabular}{cccc} 
Vloertype & & Geur emissie [OUE/s per dierplaats] & Gemiddeld (n=2) \\
\hline ICE met kleppen & Bedrijf 1 & Bedrijf 2 & 35.1 \\
\hline ICE & 34.3 & 35.8 & 46.5 \\
\hline EasyFix & 60.3 & 32.7 & 48.5 \\
\hline Standaard hardhouten rooster & 60.6 & 36.4 & 40.9 \\
\hline
\end{tabular}

De gemeten geuremissies van de vloeren laten een variabeler beeld zien dan de ammoniakemissies. De verschillen tussen en binnen bedrijven zijn soms aanzienlijk (zie bv ICE en Easyfix). Geen van de waargenomen verschillen is statistisch significant.

De geurmetingen zijn ook uitgedrukt als procentuele toe- of afname ten opzichte van de referentieafdelingen. Dit is weergegeven in tabel 18.

Tabel 18. Geuremissiereductie (in \%) van de onderzochte vloeren ten opzichte van de hardhouten referentievloer op beide blankvleesbedrijven.

\begin{tabular}{cccc} 
Vloertype & \multicolumn{3}{c}{ Gemiddelde $\mathbf{\pm}$ standard afwijking } \\
& Bedrijf 1(n=6) & Bedrijf 2(n=6) & Gemiddeld (n=12) \\
\hline ICE met kleppen & $26.2 \pm 24.8$ & $-1.2 \pm 17.3$ & $12.5 \pm 14.7$ \\
\hline ICE & $-29.7 \pm 18.8$ & $7.6 \pm 12.1$ & $-11.1 \pm 12.5$ \\
EasyFix & $-30.4 \pm 25.1$ & $-2.8 \pm 14.9$ & $-16.6 \pm 14.8$ \\
\hline
\end{tabular}

$(-)$ : negatieve waarden betekenen een geurtoename ten opzichte van de referentie

De ICE-vloer met kleppen laat gemiddeld over alle metingen een geringe reductie van de geuremissie zien, terwijl er bij de gewone ICE-vloer en de Easyfix sprake lijkt van een geringe geurtoename. Zoals al aangegeven, zijn deze verschillen niet significant en komen deze vooral voor rekening van de metingen op bedrijf 1 . Op bedrijf 2 zien we geen noemenswaardige veranderingen van de geuremissie als gevolg van de vloeren.

\subsubsection{Economische evaluatie}

In deze paragraaf worden de economische aspecten van de alternatieve vloeren beschreven. Op basis van de (actuele) investeringsbedragen en de jaarkosten (rente, afschrijving, onderhoud) wordt uitgerekend wat de meerkosten van beide type vloeren ten opzichte van de gangbare referentievloer 
zijn (hardhouten roostervloer voor blankvlees en betonroostervloer bij rosé). Indien er verschillen zijn geconstateerd in technische resultaten tussen de referentie en de alternatieve vloeren, dan wordt dit in de berekening meegenomen.

In tabel 19 staan de investeringskosten van de verschillende onderdelen. Voor zowel blankvlees als rosé vlees is uitgegaan van een leef oppervlakte van $1,8 \mathrm{~m}^{2}$ per vleeskalf. Bij rosé kalveren wordt ervan uitgegaan dat ook bij de startkalveren (opfok rosé) een extra investering voor de alternatieve vloer gedaan wordt. Bij deze startkalveren is uitgegaan van een leef oppervlakte van $1,5 \mathrm{~m}^{2}$ per kalf en vier rondes per jaar. De (oud) rosékalveren worden dus 3 maanden als startkalf gehouden met daarna de mestfase van 7 maanden. Hetgeen betekent dat de totale ronde duur 10 maanden bedraagt ( 1,2 rondes per jaar) en de rosé kalveren gemiddeld op $1,7 \mathrm{~m}^{2}$ gehuisvest worden. Zowel in de referentiestal als in de stallen met alternatieve vloeren is een ondervloer (hout of beton) vereist. De investeringen hiervoor worden apart vermeld evenals de investeringen voor de alternatieve vloeren (de matten) (zie tabel 20). Bij renovatie bij blankvlees kalveren is vervanging van de houten ondervloer nodig (bredere balken), hetgeen een extra investering vereist. Bij de ICE kappen is ook een variant met kleppen in de mestspleet meegenomen. De kosten worden zowel voor nieuwbouw als renovatie berekend, waarbij voor renovatie extra kosten voor arbeid en in het geval van blankvleeskalveren voor vervanging van de ondervloer en voor het verwijderen van voer- en stalinrichting zijn. In geval van nieuwbouw met een alternatieve vloer hoeft bij blankvlees niet voor een houten ondervloer gekozen te worden. Een betonrooster kan dan immers ook. Dit kan een besparing opleveren in de kosten van de ondervloer (geen onderslagbalken nodig en langere levensduur). Hiermee is in de berekeningen geen rekening gehouden.

Alle benoemde bedragen zijn exclusief BTW. De investering voor de ICE vloer bedraagt $€ 96$ per $\mathrm{m}^{2}$ voor het materiaal plus $€ 6$ per $\mathrm{m}^{2}$ voor de montage. Voor de kleppen in de mestspleet bedragen de materiaalkosten van de vernieuwde kleppen vandaag de dag $€ 45$ per $\mathrm{m}^{2}$ en bedraagt de totale investering (incl. arbeid voor montage) $€ 50$ per $\mathrm{m}^{2}$. De investering voor de Easyfix vloer bedraagt $€ 56$ per $\mathrm{m}^{2}$ voor het materiaal plus (naar schatting) $€ 4$ per $\mathrm{m}^{2}$ voor de montage. De investering voor een houten ondervloer bedraagt inclusief montage $€ 50$ per $\mathrm{m}^{2}$.

Ter indicatie wordt hier ook de investering van een reguliere stal vermeld. Deze bedraagt volgens KWIN-Veehouderij 2016/2017 $€ 1.330$ per dierplaats voor blankvlees kalveren en $€ 1.060$ per dierplaats voor rosé kalveren.

\section{Afschrijving \& onderhoud}

Er zijn 3 afschrijvingsscenario's uitgewerkt. De referentie wordt gevormd door KWIN-Veehouderij met de daarbij behorende percentages voor afschrijving en onderhoud. De investeringen en schattingen voor levensduur en onderhoud worden in tabel 19 weergegeven. KWIN-Veehouderij gaat uit van een levensduur van 20 jaar voor ruwbouw en 10 jaar voor de inrichting. Betonroosters gaan 20 jaar mee, maar andere roosters 10 jaar. In het scenario "gebruikers" is de afschrijving van de alternatieve vloeren van 10 naar 7 jaar teruggebracht (zie bijlage 12). In het scenario "leveranciers" is deze opgehoogd naar 20 jaar omdat de leveranciers van beide systemen de technische levensduur van hun zachte vloeren op 20 jaar inschatten. De kleppen van de ICE vloer zijn zeer kwetsbaar en de (zichtbare) functionaliteit ervan was aan het einde van het onderzoek op alle bedrijven verdwenen. Om die reden hebben we de levensduur op 5 jaar ingeschat. De afschrijving in 5 jaar is aangehouden bij de economische berekeningen. 
Tabel 19. Investeringsbedragen, levensduur en onderhoud van diverse onderdelen.

\begin{tabular}{|c|c|c|c|c|c|c|}
\hline \multirow[t]{2}{*}{ Uitgangspunten } & \multirow{2}{*}{$\begin{array}{l}\text { Investering } \\
\left(\boldsymbol{C} \text { per } \mathbf{m}^{2}\right)\end{array}$} & \multicolumn{3}{|c|}{ Geschatte levensduur (jaar) } & \multicolumn{2}{|c|}{ Geschat onderhoud ( $\%$ ) } \\
\hline & & KWIN & Gebruiker & Leverancier & KWIN & Gebruiker \\
\hline Betonrooster & & 20 & & & & 0 \\
\hline Hardhoutenrooster & & 10 & & & & 2 \\
\hline ICE & 102 & 10 & 7 & 20 & 2 & 2 \\
\hline ICE + kleppen & 50 & $5^{*}$ & $5^{*}$ & $5^{*}$ & 2 & \\
\hline Easyfix & 60 & 10 & 7 & 20 & 2 & 4 \\
\hline Ondervloer (hout/beton) & 50 & $10 / 20$ & $10 / 20$ & & 2 & 2 \\
\hline
\end{tabular}

* Levensduur van kleppen is door onderzoekers aangenomen en niet door gebruiker of leverancier

\section{Technische resultaten}

Tijdens het testen van de alternatieve vloeren zijn er alleen (bijna significante) verschillen in uitval bij rosé kalveren geconstateerd. De uitval tijdens de afmest (vanaf 12 weken tot slacht) van rosé kalveren bleek lager te zijn op de twee alternatieve vloeren (Easyfix en ICE) ten opzichte van betonnen roosters. In de stal met referentievloer (beton) was de uitval 2,5\%, terwijl die op de ICE $1,7 \%$ was en op de Easyfix 1,8\%. Deze verschillen worden niet in de berekening meegenomen. Andere belangrijke technische resultaten als groei, voeropname, aflevergewicht worden eveneens buiten de economische evaluatie gehouden omdat daar geen significante verschillen zijn vastgesteld. Om de economische verschillen tussen de vloeren per $\mathrm{kg}$ geslacht gewicht te kunnen uitdrukken, worden enkele normen uit KWIN Veehouderij 2016-2017 gebruikt. Dit betreft het aflevergewicht (na slachten) en het aantal rondes per jaar. Het aflevergewicht van een blank vleeskalf is $142 \mathrm{~kg}$ en bij 1,8 ronde per jaar levert dit $255,6 \mathrm{~kg}$ geslacht gewicht op. Het aflevergewicht voor een rosé kalf is $195 \mathrm{~kg}$ maal 1,2 ronde is $234 \mathrm{~kg}$ geslacht gewicht per dierplaats.

In tabel 20 worden op basis van de investeringsbedragen en de jaarlijkse kosten de meerkosten voor de toepassing van zachte vloeren berekend volgens KWIN. Bij renovatie moet extra arbeid worden gerekend. Bij blankvlees kalveren moeten hokinrichting en melkleidingen verwijderd worden om de alternatieve vloeren te kunnen plaatsen. De kosten hiervoor worden geschat op $€ 10$ per dierplaats en worden uitgesmeerd over de levensduur van de alternatieve vloer. Bij rosé kalveren is het betonrooster vaak al geschikt om de matten te plaatsen en zijn er eventueel kosten voor het frezen om de roosterspeten te verbreden. Deze kosten worden ingeschat op $€ 6$ per dierplaats en gelden alleen voor de ICE vloer. De Easyfix vloer kan passend worden geproduceerd naar maatvoering van de betonroosters. Dit brengt geen extra kosten met zich mee. 
Tabel 20. Meerkosten van zachte vloeren ten opzichte van een betonvloer (KWIN-Vee).

\begin{tabular}{|c|c|c|c|c|c|c|}
\hline & \multirow{2}{*}{$\begin{array}{l}\text { Referentie } \\
\text { Blankvlees }\end{array}$} & \multicolumn{3}{|c|}{ Nieuwbouw } & \multicolumn{2}{|c|}{ Renovatie } \\
\hline & & ICE & $\begin{array}{c}\text { ICE } \\
\text { kleppen }\end{array}$ & Easyfix & ICE & Easyfix \\
\hline \multicolumn{7}{|l|}{ Investeringen } \\
\hline - Alternatieve vloer & & 184 & 184 & 108 & 184 & 108 \\
\hline $\begin{array}{l}\text { - Verwijderen en } \\
\text { terugplaatsen } \\
\text { inrichting }\end{array}$ & & & & & 10 & 10 \\
\hline \multicolumn{7}{|l|}{ Jaarkosten } \\
\hline - Afschrijving & & 18,4 & 36,7 & 10,8 & 28,4 & 20,8 \\
\hline - Onderhoud & & 3,7 & 3,7 & 2,2 & 5,5 & 4,0 \\
\hline - Rente & & 2,8 & 4,1 & 1,6 & 4,3 & 3,1 \\
\hline $\begin{array}{l}\text { Totaal jaarkosten } \\
(\boldsymbol{C} / \mathrm{dpl})\end{array}$ & & 25 & 45 & 15 & 38 & 28 \\
\hline - Alternatieve vloer & & 222 & 222 & 131 & 222 & 131 \\
\hline $\begin{array}{l}\text { - Extra arbeid } \\
\text { renovatie }\end{array}$ & & & & & 7 & \\
\hline $\begin{array}{l}\text { - kleppen in } \\
\text { mestspleet }\end{array}$ & & & 111 & & & \\
\hline $\begin{array}{l}\text { Totaal investering } \\
(\mathrm{C} / \mathrm{dpl})\end{array}$ & & 222 & 333 & 131 & 229 & 131 \\
\hline \multicolumn{7}{|l|}{ Jaarkosten } \\
\hline - Afschrijving & & 22,2 & 44,4 & 13,1 & 22,9 & 13,1 \\
\hline - Onderhoud & & 4,4 & 6,7 & 2,6 & 4,6 & 2,6 \\
\hline - Rente & & 3,3 & 5,0 & 2,0 & 3,4 & 2,0 \\
\hline $\begin{array}{l}\text { Totaal jaarkosten } \\
(\mathrm{C} / \mathrm{dpl})\end{array}$ & & 30 & 56 & 18 & 31 & 18 \\
\hline C per kg & & C 0,09 & c 0,17 & C 0,05 & 0,09 & C 0,05 \\
\hline
\end{tabular}

\section{Meerkosten blankvlees}

De extra jaarkosten van de zachte vloeren worden uitgedrukt per kg vlees en bedragen in het KWINscenario bij blank vleeskalveren $€ 0,10$ per $\mathrm{kg}$ voor ICE en $€ 0,06$ per $\mathrm{kg}$ voor Easyfix bij nieuwbouw. Als er bij de ICE ook kleppen voor de mestspleet worden toegepast, bedragen de meerkosten $€ 0,17$ per $\mathrm{kg}$. Dat dit zoveel hoger is, komt door de extra investering en de korte levensduur van 5 jaar. Bij renovatie bedragen de meerkosten respectievelijk $€$ 0,15 en $€$ 0,11 per kg voor ICE en Easyfix.

\section{Meerkosten rosévlees}

De extra jaarkosten ten opzichte van de referentiestal worden uitgedrukt per kg vlees en bedragen bij rosé vleeskalveren $€ 0,09$ per $\mathrm{kg}$ voor ICE en $€ 0,05$ per $\mathrm{kg}$ voor Easyfix bij nieuwbouw. Als er bij de ICE vloer ook kleppen voor de mestspleet worden toegepast, bedragen de meerkosten $€ 0,17$ per kg. 
Dat dit zoveel hoger is, komt door de extra investering en de korte levensduur van 5 jaar. Bij renovatie bedragen de meerkosten $€ 0,09$ en $€ 0,05$ per $\mathrm{kg}$ voor respectievelijk ICE en Easyfix. In de genoemde bedragen per kg geslacht gewicht zijn de meerkosten voor de zachte vloeren tijdens de opfokfase inbegrepen. De meerkosten tijdens de opfokfase maken ongeveer $25 \%$ uit van de totale meerkosten per kg geslacht gewicht.

\section{Besparingen}

De besparing op arbeid (schoonmaken afdeling) bedraagt ca. 0,5 uur per afdeling van 60 kalveren. Bij een arbeidsloon van $€ 25$ per uur en een aflevergewicht van $142 \mathrm{~kg}$ is de besparing op arbeidskosten $(0,5 / 60) / 142 * € 25=€ 0,001$ per $\mathrm{kg}$. Deze besparing valt in het niet bij de meerkosten van de investeringen.

In tabel 21 worden de meerkosten afgezet tegen de opbrengstprijs, om gevoel te krijgen bij de impact van deze meerkosten. De relatieve meerkosten liggen tussen de 1,2\% en 2,7\% voor de alternatieve vloeren. In het geval er kleppen in de mestspleet gelegd worden, kan dit oplopen tot 5,1\%. Ook bij renovatie in blankvlees stallen lopen de relatieve meerkosten op tot 3,2\%. Voor de twee andere afschrijvingsscenario's (gebruikers en leveranciers) zijn de jaarkosten op een vergelijkbare wijze berekend. Deze zijn opgenomen in bijlage 12 van dit rapport.

Tabel 21. Relatieve kostentoename alternatieve vloeren (KWIN Vee).

\begin{tabular}{lcccccc}
\multicolumn{1}{c}{ Kostentoename t.o.v. opbrengstprijs } & Nieuwbouw & & & Renovatie \\
& $(€$ per $\mathrm{kg})$ & ICE & ICE kleppen & Easyfix & ICE & Easyfix \\
\hline Opbrengst blank vlees & 4,59 & $2,1 \%$ & $3,8 \%$ & $1,2 \%$ & $3,2 \%$ & $2,4 \%$ \\
\hline Opbrengst rosé vlees & 3,34 & $2,7 \%$ & $5,1 \%$ & $1,6 \%$ & $2,8 \%$ & $1,6 \%$ \\
\hline
\end{tabular}

In tabel 22 staat de inschatting van de extra jaarkosten samengevat voor KWIN Veehouderij, de gebruikers en de leveranciers. De geschatte meerkosten in nieuwbouw situatie liggen bij blankvlees tussen $€ 0,04$ en $€ 0,21$ per $\mathrm{kg}$. Voor rosé kalveren bedragen deze kosten in nieuwbouw situatie $€ 0,04$ tot $€ 0,22$ per $\mathrm{kg}$. De varianten met kleppen zijn het duurst, vanwege de extra investeringen en de korte levensduur. Bij renovatie zijn de kosten vooral bij blankvlees kalveren hoger, vanwege de noodzakelijke vervanging van de ondervloer. De gebruikers verwachten een kortere levensduur van de zachte vloeren, waardoor zij de meerkosten hoger inschatten dan de leveranciers.

Tabel 22. Samenvatting meerkosten van zachte vloeren bij blankvlees en rosé kalveren bij verschillende afschrijvingstermijnen( $€$ per $\mathrm{kg}$ geslacht gewicht).

\begin{tabular}{|c|c|c|c|c|c|c|}
\hline & \multirow[b]{2}{*}{ Blankvlees } & \multicolumn{3}{|c|}{ Nieuwbouw } & \multicolumn{2}{|c|}{ Renovatie } \\
\hline & & ICE & $\begin{array}{l}\text { ICE } \\
\text { klep }\end{array}$ & Easyfix & ICE & Easyfix \\
\hline KWIN Vee $(10 \mathrm{jr})$ & & 0,10 & 0,17 & 0,06 & 0,15 & 0,11 \\
\hline Gebruikers (7 jr) & & 0,13 & 0,21 & 0,08 & 0,18 & 0,14 \\
\hline \multirow[t]{2}{*}{ Leveranciers (20 jr) } & & 0,06 & 0,14 & 0,04 & 0,09 & 0,07 \\
\hline & Rosé & ICE & $\begin{array}{l}\text { ICE } \\
\text { klep }\end{array}$ & Easyfix & ICE & Easyfix \\
\hline KWIN Vee $(10 \mathrm{jr})$ & & 0,09 & 0,17 & 0,05 & 0,09 & 0,05 \\
\hline Gebruikers (7 jr) & & 0,13 & 0,22 & 0,09 & 0,14 & 0,09 \\
\hline Leveranciers (20 jr) & & 0,06 & 0,16 & 0,04 & 0,07 & 0,04 \\
\hline
\end{tabular}

\subsubsection{Gebruikerservaringen kalverhouders}

$\mathrm{Na}$ het afleveren van de laatste koppels kalveren zijn alle deelnemende bedrijven bezocht en is aan de hand van een vragenlijst (bijlage 14) de ervaring van de kalverhouders vastgelegd. Naast de verzamelde data gemeten aan de kalveren geeft dit een goed inzicht in de ervaring die de kalverhouders hebben opgedaan met de alternatieve vloeren. In tabel 23 staan de ervaringen van de kalverhouders met de alternatieve vloeren ten opzichte van hun referentievloeren vermeld. 
Tabel 23. Samenvatting enquête kalverhouders*.

\begin{tabular}{|c|c|c|c|c|}
\hline \multicolumn{5}{|c|}{ Samenvatting enquête } \\
\hline & \multicolumn{2}{|c|}{ Blankvlees bedrijven } & \multicolumn{2}{|c|}{ Rosé bedrijven } \\
\hline & Easyfix & ICE & Easyfix & ICE \\
\hline gladheid vloeren kalverhouder & 3,8 & 5,8 & 4,3 & 4,7 \\
\hline gladheid vloeren kalveren & 4,0 & 5,3 & 4,7 & 4,7 \\
\hline bevuiling kalveren & 4,8 & 4,5 & 5,0 & 3,3 \\
\hline arbeid schoonmaken & 3,5 & 3,5 & nvt & nvt \\
\hline
\end{tabular}

$* 2=$ minder glad $; 4=$ gelijk; 6 = gladder/vuiler

\section{Blankvleesbedrijven}

De kalverhouders met blanke vleeskalveren komen nadat de kalveren uit de eenlingboxen losgelaten zijn zeer regelmatig bij de kalveren in de hokken om te sorteren en kalveren te behandelen.

De beloopbaarheid van de ICE vloer werd als te glad beoordeeld. Bij activiteiten in de hokken, tussen de kalveren, was het lastig zich staande te houden.

Door de kalverhouders werd opgemerkt dat de kalveren vooral de eerste 4-8 weken (nadat ze uit de eenlingboxen komen) regelmatig uitglijden en daardoor voorzichtiger gaan lopen. Volgens de kalverhouders passen de kalveren zich op de proefvloeren na enkele weken aan de vloer aan zodra ze in groepen lopen. Door andere kalverhouders wordt het verwoord als 'wennen aan de vloer' waarna ze zich prima verder voortbewegen.

De bevuiling van de kalveren werd niet verschillend beoordeeld voor de beide vloeren. Nagenoeg alle kalverhouders hebben kanttekeningen bij de Easyfix vloer geplaatst voor wat betreft loslatende elementen en/of beschadigingen. Regelmatig moest er onderhoud worden gepleegd aan de vloer. Bij enkele kalverhouders zijn loslatende elementen met schroeven vastgezet om schuiven te voorkomen. Het reinigen van de vloeren vergt ca. $20 \%$ minder tijd dan de referentievloer. De ICE vloer met flappen was erg lastig te reinigen vanwege de rand waaraan de flappen bevestigd zijn.

De verwachtingen betreffende de alternatieve vloeren t.a.v. verbeteren technische resultaten, gedrag en gezondheid werd door de kalverhouders wisselend beantwoord. Een aantal kalverhouders verwacht met name meer effect op groei, deels door meer comfort, minder pootgebreken. Op basis van de terugkoppeling van de slachtgegevens van de eigen koppels werd opgemerkt dat de technische resultaten van de koppels op de proefvloeren tegenvielen. Bij de vraag wat men met de vloeren gaat doen na afloop van de proef en mogelijke aanschaf van alternatieve vloeren bij nieuwbouw werd door alle kalverhouders aangegeven dat de huidige vloeren blijven liggen. De keuze van de vloer bij nieuwe investeringen was wisselend. Enkele kalverhouders kiezen voor de Easyfix toplaag mits verbeteringen worden doorgevoerd, anderen kiezen voor ICE (zonder flappen), waarbij de hoge investering nog wel een aandachtspunt is.

\section{Rosébedrijven}

Door de rosé kalverhouders zelf werd geen verschil tussen de alternatieve vloeren geconstateerd m.b.t. de beloopbaarheid. Bij drie kalverhouders waren de vloeren vergelijkbaar qua gladheid met de betonnen referentievloer en bij twee waren de beide vloeren gladder tot te glad. Wat betreft de gladheid voor de kalveren merken de kalverhouders op dat dit met name speelt tot 4-6 weken na opzet.

Bij de rosé kalveren worden de vloeren minder frequent of in het geheel niet gereinigd. De bevuiling werd verschillend beoordeeld. Met name de oud rosé kalverhouders gaven aan dat ze positieve effecten hebben gezien van de proefvloeren t.o.v. de referentievloer op het voorkomen van gewrichtsproblemen c.q. dikke knieën en staart betrappen.

De beide vloeren blijven ook bij de rosé kalverhouders liggen. Voorkeur voor een alternatieve vloer in geval van nieuwbouw was 50/50 voor beide vloeren. Verbeterpunten voor de vloeren waren vergelijkbaar met de blanke kalverenbedrijven 


\subsection{Discussie}

\subsubsection{Waarnemingen dier}

Verreweg het meeste wetenschappelijke onderzoek tot nu toe naar de effecten van vloertype op het welzijn van (jonge) runderen is gedaan bij vleesstieren die tot een aanzienlijk hoger gewicht worden afgemest dan vleeskalveren. Niettemin komen de resultaten uit het huidige onderzoek op aan aantal punten overeen met de literatuur.

\subsubsection{Gedrag}

De meerderheid van het onderzoek naar effecten van (varianten van) rubber op de vloer bij vleesstieren wijst op positieve effecten op het gedrag van de dieren. Uit een aantal studies blijkt dat stieren op rubber ten opzichte van stieren op betonnen roosters minder vaak uitglijden (Gygax et al., 2007; Cozzi et al., 2013), en elkaar vaker bespringen (Brscic et al., 2015; Earley et al., 2015). Dit beeld wordt ondersteund door de resultaten van het huidige gedragsonderzoek bij vleeskalveren voor zover het de Easyfix vloer betreft (hetzelfde type vloer dat door Earley et al., 2015, bij vleesstieren is onderzocht). Op de Easyfix vloer lieten blankvleeskalveren twee weken voor slachten significant minder uitglijden zien dan op de referentievloer bestaande uit houten roosters. Eenzelfde resultaat werd ook gevonden in de voorstudie bij zowel blankvlees - als rosékalveren. Een oriënterend onderzoek met vleeskalveren uitgevoerd in 2004, waarin relatief brede $(11 \mathrm{~cm})$ houten roosters werden vergeleken met dezelfde roosters voorzien van een rubberen toplaag met luchtkamers kwam tot een vergelijkbaar resultaat, namelijk minder uitglijden door kalveren gehuisvest op rubber in vergeleken met hout (De Lauwere et al., 2004).

Een consistente vinding is dat stieren op rubber er korter over doen om te gaan staan en te gaan liggen, en vaker van houding veranderen dan stieren op beton (Ruis-Heutinck et al., 1999; Absmanner et al., 2009; Graunke et al., 2011; Cozzi et al., 2013; Brscic et al., 2015; Elmore et al., 2015; ). In een aantal studies werd ook gerapporteerd dat stieren op beton veel vaker abnormaal gaan staan en gaan liggen - via de zogenaamde 'hondenzit' - in vergelijking met stieren op rubber (Ruis-Heutinck et al., 1999; Gygax et al., 2007). De meest gebruikte verklaring voor deze resultaten is dat (vooral zware) stieren op beton pijn en ongerief ervaren bij het gaan staan en gaan liggen, waardoor ze enerzijds minder vaak van houding veranderen, en in extreme gevallen zelfs de manier waarop ze gaan staan en gaan liggen drastisch wijzigen in een poging om hoge druk op de gewrichten in de voorpoten zoveel mogelijk te vermijden. Relevant is dat abnormaal gaan staan en gaan liggen in het huidige onderzoek bij vleeskalveren nauwelijks is waargenomen, noch in de voorstudie (waar in detail de manier van gaan staan en gaan liggen is beoordeeld), noch in de praktijkstudie.

\subsubsection{Klinische gezondheid}

In overeenstemming met de hierboven genoemde gedragsveranderingen laten stieren op beton ten opzichte van dieren op rubber ook relatief veel huidbeschadigingen, lesies aan de klauwen, en kreupelheid zien (Ruis-Heutinck et al., 1999; Platz et al., 2007; Schultze-Westerath et al., 2007; Graunke et al., 2011; Rouha-Mülleder et al., 2012; Brscic et al., 2015). Ook op dit punt wijken de bevindingen bij vleeskalveren sterk af van die bij vleesstieren. Kreupelheid en lesies aan klauwen en gewrichten werden in het huidige onderzoek nauwelijks gezien. Het lijkt waarschijnlijk dat dergelijke klinische problemen bij vleeskalveren nauwelijks voorkomen omdat ze niet alleen korter op een bepaalde vloer verblijven, maar ook minder zwaar worden dan vleesstieren.

Uit een aantal onderzoeken met vleesstieren komt een omgekeerd beeld naar voren, namelijk meer beschadigingen aan de klauwen (zoal erosies en witte lijn lesies) bij stieren op rubber dan bij stieren op beton (Earley et al., 2015; Keane et al., 2015). Ter verklaring werd ondermeer verondersteld dat een vloer met rubber relatief nat kan zijn, waardoor de hoornlaag van de klauw verzwakt zou kunnen worden met als gevolg dat pathogenen een grotere kans hebben om binnen te dringen in het weefsel van de klauw (Earley et al., 2015). Keane et al. (2015) troffen bij stieren op rubber ook meer lange klauwen aan dan bij stieren op beton, en suggereerden dat daardoor het gewicht van stieren op rubber teveel op de achterkant van de klauw terecht zou komen, met als gevolg een te grote lokale druk en een grotere kans op beschadiging van de klauw. Deze laatste verklaring wordt niet ondersteund door een aantal andere onderzoeken waarin eveneens gemiddeld gezien langere klauwen 
werden waargenomen onder stieren op rubber ten opzichte van stieren op beton - naar alle waarschijnlijkheid ten gevolge van een verminderde slijtage van de klauwen op rubber - maar tegelijkertijd juist minder klauwbeschadigingen en kreupelheid bij de dieren op rubber werden aangetroffen (Platz et al., 2007; Rouha-Mülleder et al., 2012; Brscic et al., 2015). Ook in het huidige onderzoek werden verlengde klauwen een aantal keren gescoord (in de voorstudie) en expliciet gemeld door een aantal deelnemende kalverhouders. Het feit dat klinische problemen met het beenwerk zoals kreupelheid in de huidige proef bijna niet zijn gezien, ondersteunt de gedachte dat langere klauwen onder vleeskalveren gehouden op Easyfix of ICE, voor zover ze zich hebben voorgedaan niet hebben geleid tot verdere problemen.

De alternatieve vloertypen bleken een duidelijk effect te sorteren op de prevalentie 'dikke knieën': zowel bij blankvlees- als rosékalveren was de prevalentie van 'dikke knieën' onder dieren gehuisvest op ICE of Easyfix significant lager ten opzichte van dieren gehuisvest op de referentievloer. In de veterinaire literatuur staat deze aandoening bekend als carpale bursitis, carpale hygroma of subcutane bursitis; dit is een zachte en doorgaans pijnloze zwelling van het kniegewricht van één of beide voorpoten (Bovine Medicine: Diseases and Husbandry of Cattle, 1991; Cattle Medicine, 2011). Deze vorm van bursitis wordt veroorzaakt door frictie en te hard contact tussen het gewricht en een contactpunt uit de omgeving van het dier, zoals bijvoorbeeld een onderdeel van een te kleine ligbox (bij melkkoeien) of een harde vloer. Een veterinaire behandeling tegen deze aandoening is over het algemeen niet nodig; bij koeien is plaatsing in een strohok of in de wei meestal voldoende om de zwelling te doen verdwijnen. Carpale bursitis is duidelijk te onderscheiden van infectieuze aandoeningen aan het gewricht, die ook met zwelling gepaard kunnen gaan, omdat dan sprake is van pijn en kreupelheid. Eén van de weinige onderzoeken naar verschillende vloertypen bij vleeskalveren (Brscic et al. (2011) wijst in dezelfde richting als het huidige onderzoek. In de studie van Brscic et al. (2011) werd gebruik gemaakt van een dataset met gegevens van in totaal 174 vleeskalverbedrijven (blankvlees). Onder deze steekproef bleek op 6\% van de bedrijven stro of rubber gebruikt te worden als vloertype, en op $14 \%$ van de bedrijven beton. Op bedrijven met stro of rubber als vloertype was de prevalentie van kalveren met bursitis aanzienlijk lager dan op bedrijven met houten roosters of beton als vloertype. Onderzoek met vleesstieren is ook in overeenstemming met de huidige bevindingen. Onder stieren gehuisvest op (varianten van) rubber kwamen zwellingen aan gewrichten, waaronder carpale bursitis, significant minder voor dan onder stieren gehuisvest op betonnen roosters (Schultze-Westerath et al., 2007; Graunke et al., 2011; Elmore et al., 2015). Deze gegevens suggereren dat huisvesting van vleeskalveren op een relatief zachte vloer, zoals Easyfix of ICE, gepaard gaat met meer comfort voor het dier.

\subsubsection{Gebruik antibiotica en uitval}

Uit de literatuur is bekend dat het vloertype of het substraat waarmee de vloer van een kalverhok wordt bedekt een effect kan hebben op de gezondheid van (fok)kalveren en het gebruik van antibiotica (zie, bijvoorbeeld, Paninivat et al., 2004). Uit het huidige onderzoek blijkt dat zowel bij blankvlees- als rosékalveren het vloertype geen effect had op het gebruik van antibiotica. Dat wijst erop dat de vatbaarheid voor infectieuze ziekten niet werd beïnvloed door het vloertype. In lijn hiermee is de vinding dat de uitval niet significant door het vloertype werd beïnvloed.

\subsubsection{Pathologie}

De uitkomsten van onderzoek naar pathologische afwijkingen aan de longen op het slachthuis is ook een ondersteuning voor het idee dat de ziektegevoeligheid - in het bijzonder de gevoeligheid voor luchtwegaandoeningen - niet afhankelijk was van het vloertype. Bij zowel blankvlees- als rosékalveren had vloertype geen effect op het vóórkomen van beschadigingen in de longen of op pleuritis.

\subsubsection{Bevuiling en bezoedeling}

Het contrast tussen de referentievloer en de twee alternatieve vloertypen in de mate van bevuiling van de kalveren op het vleeskalverbedrijf bleek verschillend te zijn voor blankvleeskalveren en rosékalveren. Wat verder opvalt in de huidige resultaten ten aanzien van de bevuiling van kalveren op het kalverbedrijf is dat de effecten van vloertype consistent aanwezig zijn gedurende de gehele mestperiode over de verschillende deelnemende bedrijven heen. Bij blankvleeskalveren waren dieren gehuisvest op Easyfix en ICE over het algemeen wat vuiler, maar de gemiddelde bevuilingsscores bij blanke kalveren waren over het algemeen op alle vloeren lager dan de gemiddelde bevuilingsscores 
van rosékalveren. Bij rosékalveren was de bevuiling van kalveren op de Easyfix vloer over het algemeen vergelijkbaar met die van kalveren op betonnen roosters, terwijl de bevuiling van kalveren op ICE in vergelijking met die van dieren op de referentievloer beduidend lager was. Cruciaal is dat zowel voor blankvlees- als voor rosékalveren werd aangetoond dat significante verschillen in bevuiling op het vleeskalverbedrijf geen consequenties hadden voor de (blind beoordeelde) bevuiling van kalveren bij aankomst op het slachthuis. Slechts enkele vrachten - met bovendien kalveren afkomstig van verschillende vloertypen - werden op het slachthuis als vuil beoordeeld. Dit toont aan dat vanuit het oogpunt van slacht hygiëne de toepassing van een alternatieve vloer, zoals Easyfix of ICE, bij vleeskalveren mogelijk is.

Uit de literatuur over bevuiling van vleesstieren op verschillende vloertypen komt het beeld naar voren dat er tussen individuele studies duidelijke verschillen in uitkomsten kunnen bestaan. Zo werd in een aantal studies gevonden dat vleesstieren op rubber vuiler waren dan dieren op beton (Graunke et al., 2011; Brscic et al. 2015; Earley et al., 2015), terwijl in andere experimenten de bevuiling van stieren op rubber niet verschilde van die van stieren op beton (Low et al., 2001; Keane et al., 2015). Wellicht dat verschillen in rantsoen - samenhangend met verschillen in consistentie en kwaliteit van de mest hierbij een rol hebben gespeeld. In het huidige onderzoek bij vleeskalveren is juist afdoende rekening gehouden met verschillen tussen bedrijven en tussen koppels in bijvoorbeeld management en voeding. Dat maakt de verschillen die in het huidige onderzoek zijn gevonden des te algemener.

\subsubsection{Geslacht gewicht en voeropname}

In een aantal studies bij vleesstieren is gevonden dat dieren op betonnen roosters voorzien van een rubberen toplaag in vergelijking met dieren op kale betonnen roosters een hogere groei (levend gewicht) lieten zien (Cozzi et al., 2013; Brscic et al., 2015; Keane et al, 2015). In veel andere studies geeft rubber op de vloer geen verbetering van de groei (levend en/of karkas) (Ruis-Heutinck et al., 1999; Lowe et al., 2001; Graunke et al., 2011; Earley et al., 2015; Elmore et al., 2015). Dit laatste is in overeenstemming met de huidige bevindingen bij vleeskalveren. In het experiment uitgevoerd in Ierland door Earley et al. (2015) bestond de rubberen vloer overigens uit de Easyfix mat voor vleesstieren, bevestigd op betonnen roosters, analoog aan de Easyfix vloer in het onderzoek met vleeskalveren. Ook de voeropname en de voerefficiëntie werden niet door het vloertype beïnvloed. Gelet op de verschillen tussen individuele experimenten die zijn uitgevoerd bij vleesstieren (waarbij binnen hetzelfde experiment vaak gebruik werd gemaakt van één en hetzelfde proefbedrijf) is het niet uitgesloten dat op bepaalde vleeskalverbedrijven uit de populatie die aan het huidige onderzoek hebben meegedaan wèl een positief (of negatief) effect op de groei en/of voeropname aanwezig was. Geschat over verschillende bedrijven en koppels heen waren geen betekenisvolle verschillen in groei en voeropname aantoonbaar.

\subsubsection{Waarnemingen vloeren}

De zachte vloeren van ICE en Easyfix die in het kader van het project voor vleeskalveren zijn ontwikkeld en toegepast zijn de eerste versies die breed in praktijk zijn toegepast. Na gemiddeld ruim 3 jaar ervaring is dit een eerste tussenbalans waarin waarnemingen aan dieren, beoordelingen door gebruikers, inspecties en objectieve testresultaten over elkaar heen worden gelegd om tot een oordeel te komen over de state of the art en waar nodig verbeterpunten aan te dragen.

a. Montage en bevestiging van de zachte vloeren aan de ondervloer De matten worden door de fabrikanten op maat geproduceerd, afgestemd op de ondervloer die in de stal aanwezig is of in de stal toegepast gaat worden. Beide matten laten zich eenvoudig monteren. Dit kan de veehouder in principe zelf uitvoeren. Bij de vloer van ICE worden ter hoogte van de bruggen tussen de roosterbalken vooraf inkepingen in de mat voorbereid zodat dit niet ter plaatse in de stal hoeft te gebeuren. De ICE-vloer klemt zichzelf vast aan het onderliggende rooster door beide wangen. In het gebruik hebben zich geen problemen voorgedaan dat matten los kwamen van de ondervloer. De wangen voorkomen effectief dat mest en urine tussen de mat en de ondervloer kan komen. De spleten in de duo-mat van Easyfix worden eveneens afgestemd op die van de ondervloer. De mat wordt zo nodig ter plaatse in de stal op lengte gemaakt. De Easyfix-vloer klemt zich met behulp van nokken in de tussenspleet vast aan de ondervloer. Een zekere mate van vormvastheid van de ondervloer is daarbij van belang, omdat bij wisselende spleetbreedte een afdoende klemming niet 
gegarandeerd kan worden. Dit heeft in het begin op een paar bedrijven gespeeld. Inmiddels zijn de matten voorbereid met schroefgaten om indien nodig de matten extra aan de ondervloer te kunnen fixeren. De duo-mat van Easyfix is voorzien van "skirts" (korte flapjes) aan de zijkanten van de mat. Deze hebben tot doel om de mest beter door de roosterspleet te leiden en om tegen te gaan dat mest en urine kunnen ophopen tussen mat en ondervloer. Dit laatste blijkt niet zo te zijn.

b. Duurzaamheid van de zachte vloeren

Het is niet mogelijk om na 3 jaar gebruik harde uitspraken te doen over de levensduur van de zachte vloeren in de stal. Gedurende de looptijd van het onderzoek zijn de vloeren tijdens leegstand (en zo mogelijk na reiniging) geïnspecteerd op meetbare veranderingen, beschadigingen en zichtbare aanwijzingen van slijtage. Daarnaast zijn de gebruikers bevraagd naar de (technische) en de economische levensduur. De technische levensduur is hun verwachting dat de toplagen in goede staat kunnen blijven functioneren in de stal, de economische levensduur is hun verwachting dat de toplagen afgeschreven moeten zijn omdat er om andere redenen een mogelijke verandering aan de vloeren moet gaan plaatsvinden. De fabrikanten hebben aangegeven wat hun ervaringen met vergelijkbare producten zijn, die al veel langer worden toegepast in de veehouderij.

Na drie jaar gebruik zien de toplagen in de stallen er nog goed uit en zijn deze nog volledig functioneel. Tekenen van slijtage als gevolg van normaal gebruik zijn niet zichtbaar. Wel is er soms sprake van het ontstaan van enige beschadiging aan de zijkanten van de Easyfix-mat. Het betreft korte stukjes van de rokjes of van de zijkant van de mat die losscheuren. Ten opzichte van het totaal aantal meters mat dat in het onderzoek betrokken is, is dit tot dusver zeer beperkt. Het lijkt vooral op te treden op de plaatsen waar de kalveren met voor- en achterpoten staan tijdens het vreten en vormt een aandachtspunt bij de doorontwikkeling van deze mat. De gebruikers zijn voorzichtiger in de verwachte levensduur dan de fabrikant.

Bij de ICE-vloer zijn geen beschadigingen gevonden als gevolg van normaal gebruik door de dieren. Bij de ICE-vloer geldt meer het aandachtspunt dat bij reiniging met een hoge drukreiniger dit met de juiste druk, nozzle en spuitafstand gebeurt. Ook hier zijn de gebruikers voorzichtiger wat de te verwachten levensduur betreft dan de fabrikant.

Om die reden hebben we bij de economische evaluatie gekozen om drie scenario's door te rekenen waarin de afschrijvingstermijnen van elkaar verschillen.

Op een paar bedrijven is de ICE-vloer met kleppen beproefd. Deze dienen mest en urine door te laten en de mestspleet af te sluiten wanneer dit niet het geval is. De ervaring uit het project leert dat de functionaliteit van de toegepaste kleppen al heel snel achteruit gaat en de natuurlijke veerkracht die er voor moet zorgen dat de kleppen zich sluiten snel verdwijnt. ICE heeft inmiddels een andere uitvoering van de klep ontwikkeld en voert daarmee testen uit.

\section{c. Stroefheid / beloopbaarheid}

Het beoordelen van de stroefheid en beloopbaarheid van de vloeren is een belangrijk, maar tevens heel lastig onderdeel van het onderzoek. De gebruikers beoordelen dit met in het achterhoofd hoe zij het ervaren ten opzichte van hun referentievloer (hout, dan wel beton). Ditzelfde geldt voor de gedragswaarnemingen die aan de kalveren zijn gedaan. Hiervoor geldt geen norm wat goed is en wat slecht en de beoordeling berust het vooral op een onderling vergelijk volgens een zo objectief mogelijk kader. Daarom zijn we, naast de bovengenoemde beoordelingen, ook op zoek gegaan naar een objectieve methode (De Tribo-meting) om de stroefheid van de vloeren in het gebruik te kunnen meten en de uitkomsten langs een algemeen geaccepteerde norm te kunnen leggen.

De verschillende bronnen geven geen eenduidig beeld. De Tribo-metingen laten zien dat het betonrooster de hoogste stroefheid heeft, de beide zachte toplagen gemiddeld een tussenliggende stroefheid en het hardhouten rooster als minst stroef naar voren komt. Met de Tribo-methode wordt de laagste dynamische weerstand van een loopoppervlak bepaald. In het geval van roosters is dat in de lengterichting over de roosterbalk. De dynamische weerstand is daarbij de combinatie van weerstand als gevolg van de indrukbaarheid van het materiaal als de weestand als gevolg van de ruwheid van het oppervlak. Daarom leent deze methode zich goed om indrukbare en harde loopvlakken te vergelijken.

De stroefheid van een hardhouten rooster voldoet op basis van de Tribo-test niet aan de norm voor loopoppervlakken in publieke ruimten. Deze is te glad. Gladder dan de beide zachte toplagen elk gemiddeld scoren. 
Uit de enquêtes met de kalverhouders komt het tegenovergestelde naar voren: De

blankvleeskalverhouders ervaren beide zachte vloeren beduidend gladder dan hun hardhouten rooster. In de afsluitende enquête beoordelen zij de ICE-mat gemiddeld "voldoende", de Easyfix "ruim voldoende" en het hardhouten rooster "goed" op gladheid. Voor het hardhouten rooster speelt mogelijk mee dat deze relatief veel spleten heeft, wat de grip van de klauwen en de beloopbaarheid ten goede kan komen. De beide zachte matten hebben bij blankvlees immers roosterbalken die $50 \%$ breder zijn dan die van de hardhouten roosters.

Uit de enquêtes van de rosé-bedrijven komt eveneens naar voren dat zij hun traditionele betonvloer als het best beloopbaar ervaren voor henzelf. De beloopbaarheid voor de kalveren loopt minder uiteen. Daar scoren alle 3 vloeren gemiddeld nagenoeg hetzelfde. Ook het Tribo-onderzoek laat zien dat het betonrooster een goede stroefheid heeft en ruim aan de norm voldoet. De ICE-vloer op datzelfde bedrijf voldoet net aan de norm, de Easyfix-vloer op dat bedrijf meet een te lage dynamische weerstand.

Er is een substantieel verschil tussen de uitkomsten van de stroefheidsmetingen in Overdinkel en Ede. In Overdinkel zijn consequent lagere waarden gemeten dan in Ede. Voor de Easyfix-mat 0,33 vs. 0,52 en voor de ICE-mat 0,41 vs. 0,54. Mogelijk dat de vloeren in Overdinkel wat aan stroefheid hebben verloren door het gebruik door zwaardere dieren (oud rosé) en wat langer in gebruik zijn.

Kalverhouders geven in de enquête zelf aan dat ze geen noemenswaardige veranderingen hebben waargenomen in de beloopbaarheid van de zachte vloeren.

\subsubsection{Waarnemingen stalklimaat}

De waarnemingen aan het stalklimaat zijn met behulp van temperatuur en relatieve luchtvochtigheidssensoren uitgevoerd en naderhand geanalyseerd en beoordeeld. Achtergrond hiervan was om te kijken of er verschillen tussen de afdelingen met verschillende vloertypen zouden zijn, of in de looptijd van het project zouden ontstaan. Dit bleek niet het geval. Er is vanuit het project niet gestuurd op klimaatinstellingen of differentiatie tussen vloeren, er is louter gevolgd wat in de praktijk plaats heeft gevonden. Het toepassen van zachte vloeren heeft er niet toe geleid dat anders is omgegaan met staltemperatuur of dat zich veranderingen in luchtvochtigheid hebben voorgedaan.

\subsubsection{Waarnemingen demoafdelingen}

\section{Demo ICE met kleppen}

Kalveren gehuisvest op de demo vloer ICE met kleppen zijn vuiler op alle leeftijden (in de eenlingbox, 10 weken na opzet en twee weken voor slacht) dan kalveren gehouden op de houten roostervloer. Ook het percentage bevuilde buik is hoger bij kalveren gehouden op de alternatieve vloer. Op 10 weken na opzet liep de alternatieve vloer gemiddeld voor 32,5\% op 10 weken leeftijd tot gemiddeld $58 \%$ vol met mest.

\section{Demo vaarskalveren}

Er is 1 bedrijf geweest waar voor beide alternatieve vloeren een demo afdeling met vaarskalveren gehouden werd. Vaarskalveren gehuisvest op zowel de Easyfix als de ICE vloer zijn vuiler op alle leeftijden (in de eenlingboxen, 10 weken na opzet en twee weken voor slacht) dan vaarskalveren gehouden op de houten roostervloer. Ook het percentage bevuilde buik is hoger bij kalveren gehouden op de alternatieve vloer. De vloeren werden in beide demoafdelingen ook natter dan de vloeren met stierkalveren.

\subsubsection{Ammoniak- en geuremissiemetingen}

De ammoniak- en geuremissiemetingen zijn uitgevoerd volgens de hiervoor aangewezen methoden vanuit de overheid (Ogink 2011; Ogink et al 2013). De metingen voldoen aan de vereisten en zijn derhalve bruikbaar voor het vaststellen van definitieve emissiefactoren.

$\mathrm{Er}$ is gekozen voor een case-controle aanpak, waarbij op de meetlocaties, naast de proefbehandelingen (de vloeren), ook het gangbare referentiesysteem aanwezig is en als controle dienst doet. Dit maakt dat er minder sprake is van bedrijfsinvloeden op de resultaten en er zodoende 
met minder metingen aan het proefsysteem kan worden volstaan. De methode houdt tevens in dat er geen harde uitspraken kunnen worden gedaan over de absolute hoogte van de emissies, wel over de mate waarin sprake is van een emissieverandering ten opzichte van de referentie. Achteraf bezien lijkt het verstandig geweest de keuze voor case-control te maken in plaats van metingen ten behoeve van de bepaling van een absoluut emissieniveau. Wanneer de absoluut gemeten emissieniveaus van beide referentiestallen wordt beschouwd, dan wijken deze aanzienlijk af van dat wat in de Regeling ammoniak en veehouderij (Rav) als norm geldt (gemiddeld 5,0 kg ammoniakemissie per dierplaats per jaar, ten opzichte van $3,5 \mathrm{~kg}$ wat als landelijke norm geldt voor een standaard vleeskalverplaats). Dit kan op toeval berusten als gevolg van bv bijzondere (management- of meet-)omstandigheden op beide bedrijven, hoewel we dat uit de verzamelde klimaat- en landbouwkundige gegevens niet kunnen herleiden. De gemeten emissies uit de referentiestallen liggen hoger dan uit eerder onderzoek naar voren is gekomen. Hol en Groenestein (1997) en Beurskens en Hol (2004) vonden respectievelijk gemiddeld 2,5 kg per dierplaats per jaar en 3,4 kg.

Noch de Easyfix-vloer, noch de ICE-vloer brachten verschillen aan het licht met de gemiddelde ammoniakuitstoot van de referentievloeren. De ICE-vloer neigde naar een geringe emissiereductie, de Easyfix-vloer naar een geringe toename, maar geen der verschillen was statistisch significant en ze berusten derhalve op toeval. De gevonden resultaten en onderlinge tendensen liggen in lijn met de uitkomsten van de indicatieve ammoniakmetingen uit fase 1 van het onderzoek. Vooraf was verwacht dat beide zachte vloeren, door de bolle vorm van hun toplaag, urine sneller en vollediger zouden afvoeren naar de onderliggende mestopvang, daarmee een reductie van ca $10-15 \%$ ammoniakemissie realiserend. De bijdrage van de roostervloer aan de totale ammoniakemissie wordt bij vleeskalveren op ca $30 \%$ verondersteld. Mogelijk is het beoogde effect teniet gedaan door de grotere balkbreedte die bij beide zachte vloeren is toegepast en waardoor de gemiddelde afstroomafstand is toegenomen en de netto doorlaat van de roostervloer met ca $1 / 3$ is gereduceerd.

Met de aanvullende toepassing van kleppen in de roosterspleten van de ICE-vloer is wel een statistisch significante afname van de ammoniakemissie vastgesteld. Deze reductie bedroeg gemiddeld $23 \%$. Ook deze $23 \%$ emissiereductie was lager dan vooraf verwacht. Wellicht speelt hierbij een rol dat de klepjes vaak niet functioneerden zoals beoogd. Geconstateerd is ze door aanhechting van feaces niet goed sluiten en dat kleppen na verloop van tijd ook zonder reden (gedeeltelijk) open blijven staan. De vastgestelde emissiereductie is er derhalve representatief voor matig functionerende kleppen. Hier ligt een uitdaging voor verbetering met een dito verwachting ten aanzien van de ammoniakreductie.

De emissiereductie van $23 \%$ voor de ICE-vloer met kleppen lijkt niet toereikend om te voldoen aan de emissiereductie-eis die het Besluit emissiearme huisvesting (2015) vanaf 2020 bij nieuwbouw voor vleeskalveren stelt.

Ten aanzien van het vrijkomen van geur zijn geen significante effecten van vloeruitvoering en klepjes in de roosterspleten vastgesteld. De gemeten geuremissies lieten een veel grotere spreiding zien dan bij ammoniak het geval was. De geuremissie lijkt derhalve niet direct gerelateerd aan de uitvoering van de roostervloer. Mogelijk wordt de geuremissie vooral door processen in de mestkelder bepaald.

Vooraf was beoogd om het emissie onderzoek uit te voeren op één blankvlees- en één rosébedrijf. Het bleek echter praktisch niet mogelijk om een rosékalverbedrijf te vinden met 4 identieke afdelingen, mechanische ventilatie en een opzetstrategie op basis van all-in all-out. Om die reden is uitgeweken naar een tweede blankvleesbedrijf. Binnen de regelgeving worden de emissies van bedrijven met blankvleeskalveren en rosékalveren gelijk verondersteld en heeft deze keuze geen consequenties. Feitelijk bezien is het echter de vraag of bij rosékalveren vergelijkbare reducties zullen worden vastgesteld als bij blankvlees. Naast een ander groeitraject, een andere vorm en wijze van voeren met andere stikstofexcreties, is er bij de rosékalverhouderij ook sprake van een andere referentievloer. Als we ons baseren op de indicatieve emissiemetingen die in fase 1 aan bij rosékalveren zijn uitgevoerd, dan moeten we geen hooggespannen verwachting hebben dat de zachte vloeren daar emissie technisch aanzienlijk beter zullen presteren dan de betonnen referentievloer. 


\subsubsection{Economische evaluatie}

In de economische evaluatie worden kosten en opbrengsten tegen elkaar afgezet. Opbrengsten als gevolg van aantoonbaar betere technische resultaten waren er niet. Alleen bij rosé kalveren is een bijna significante afname van het uitvalspercentage vastgesteld. Indien met deze lagere uitval gerekend wordt, levert dit een compensatie op van circa $€ 7$ per dierplaats ofwel $€ 0,02$ per $\mathrm{kg}$ geslacht gewicht. De weinige gesignaleerde besparingen, zoals gemakkelijker reinigen, minder reinigingswater, leveren nauwelijks iets op. Per saldo komt het er op neer dat er in financiële zin alleen extra kosten zijn.

De extra investering in de zachte vloeren bedraagt bij nieuwbouw voor blankvlees ca $€ 108$ per dierplaats in geval van Easyfix en $€ 184$ voor de ICE vloer. Voor rosé kalveren is dit vanwege de startkalveren hoger en is dit respectievelijk $€ 131$ voor Easyfix en $€ 222$ voor de ICE vloer. Bij gedwongen renovatie (als de oude roostervloer nog niet aan vervanging toe is), komt daar bij blankvleeskalveren voor elk van de vloeren nog eens een investering van $€ 100$ per dierplaats bovenop. Voor rosébedrijven geldt dit niet omdat de betonnen roostervloer daar vrijwel altijd geschikt is als ondervloer voor de zachte toplagen.

Uitgaande van de afschrijvingstermijnen die KWIN-Veehouderij voor vleeskalverstallen hanteert, bedragen de meerkosten van de zachte vloeren (zonder kleppen in de mestspleet) 5 tot 10 Eurocent per kg geproduceerd vlees bij nieuwbouw en bij "geforceerde" renovatie (met vervanging van de ondervloer) 5 tot 15 Eurocent per kg vlees. De laagste meerkosten zijn van toepassing op de Easyfixvloer. In een nieuwbouwsituatie zijn er nauwelijks verschillen in meerkosten tussen blankvlees kalveren en rosé kalveren, doordat bij rosé vlees ook de investeringen bij de startkalveren zijn meegerekend.

Het verhogen of verlagen van afschrijvingstermijn van de zachte toplagen heeft wel enige invloed. Wordt de veronderstelde levensduur teruggebracht van 10 naar 7 jaar dan nemen de meerkosten met ca $30 \%$ toe, wordt de levensduur naar 20 jaar verlengd dan dalen de meerkosten met ca $40 \%$.

De toepassing van zachte vloeren drukt het inkomen van de vleeskalverhouder.

Voor blankvlees bedragen de meerkosten bij nieuwbouw $€ 15$ - $€ 25$ per dierplaats per jaar (tabel 20). Voor een blankvleesbedrijf van gemiddelde omvang (d.w.z. ca. 1200 dierplaatsen) levert dit een derving van het bruto jaarinkomen op van $€ 15.000-€ 25.000$. In geval van renovatie bedragen de meerkosten $€ 28$ - $€ 38$ per dierplaats per jaar, of te wel een derving van het bruto inkomen met $€$ 33.600 - $€ 45.600$. Hierin zijn de (fiscaal) aftrekbare afschrijvingskosten niet verdisconteerd.

Bij de rosékalverhouderij ligt de gemiddelde bedrijfsomvang voor de bedrijven die zelf ook de startersfase doen op ca 600 dierplaatsen (starters + afmest). De meerkosten, omgeslagen naar de afmestplaatsen, bedragen hier zowel bij nieuwbouw als bij renovatie $€ 18$ - $€ 30$ per plaats, of te wel een toename van de jaarkosten op bedrijfsniveau met $€ 7.200-€ 12.000$.

Voor de rosékalverbedrijven die broutards aankopen ligt de gemiddelde bedrijfsomvang op ca 1000 tot 2000 dierplaatsen. Deze bedrijven krijgen te maken met hogere aankoopkosten voor hun starters en daarnaast stijgen de huisvestingskosten op hun bedrijf. Per saldo stijgen de jaarkosten op bedrijfsniveau met $€ 18.000$ - $€ 30.000$ (bij 1000 dierplaatsen) tot $€ 36.000$ a $€ 60.000$ bij 2000 dierplaatsen.

\subsubsection{Gebruikerservaringen kalverhouders}

Bij de toepassing van een toplaag over gangbare vloeren wordt verondersteld dat deze laag voordelen zal bieden aan zowel kalveren als aan de veehouder Aan de veehouders is een vragenlijst voorgelegd en zijn er metingen na een jaar en aan het einde van de proef uitgevoerd. Hier zijn een aantal zaken naar voren gekomen.

Bij de blanke kalveren moeten de veehouders de eerst weken na de eenlingperiode frequent in de hokken om de kalveren te behandelen en te sorteren. Op de rosé bedrijven wordt aan het einde van de mestperiode gesorteerd. Op die momenten is het noodzakelijk dat de beloopbaarheid van de vloer goed is zodat men zich veilig tussen de dieren kan bewegen. Dit is door de kalverhouders niet zo ervaren. Om dit op te lossen zullen de fabrikanten de vloeren stroever dienen te maken voor een betere beloopbaarheid. 
De kalveren hebben ook de eerste weken dat zij op deze vloeren verblijven problemen met de beloopbaarheid en uitglijden wordt dan ook frequent waargenomen. Na een aantal weken passen de kalveren zich aan de vloeren aan. Dit heeft geen nadelige gevolgen opgeleverd voor de kalveren. De rosé mesters zien met name voor de kalveren aan het einde van de mestperiode voordelen in de toplagen omdat problemen aan gewrichten en staart betrappen niet meer voorkomen.

Naast de stroefheid van de vloeren is ook de duurzaamheid van de vloer van belang. De toplagen zijn gedurende de proef gecontroleerd. Het blijkt dat de toplagen enkele millimeters uitlopen wat verder geen nadelige gevolgen heeft. Beschadigingen en het loskomen van de toplaag kwam bij de Easyfix vloer voor en de fabrikant zal daar aandacht aan moeten schenken omdat te verbeteren. De ICE vloer met klepjes is nog niet praktijkrijp. De spleten lopen vol met als gevolg vuile kalveren.

De reinheid van de kalveren is van belang met name tijdens het slachtproces. Het afleveren van niet vuile kalveren is een noodzaak. De kalverhouders beoordeelden de beide vloeren verschillend wat betreft de bevuiling t.o.v. de referentie vloer. Bij de blanke kalveren speelt hierbij met name de balkbreedte van de vloer een rol. De referentie vloer heeft een balkbreedte van $80 \mathrm{~mm}$ en de breedte van de toplaag varieert van $120-128 \mathrm{~mm}$. Een smallere balkbreedte en dito toplaag zullen naar verwachting een gunstig effect hebben op de reinheid van de kalveren. 
- De voorstudie heeft laten zien dat vleeskalveren een voorkeur hebben voor de in praktijkstudie onderzochte vloeren als ondergrond om op te liggen. Uit de praktijkstudie is gebleken dat onder zowel blankvlees- als rosékalveren op de alternatieve vloeren significant minder gevallen van carpale bursitis (of dikke knie) voorkomen dan onder kalveren op de referentievloeren. Deze bevindingen tonen aan dat kalveren op de alternatieve vloeren meer comfort ervaren dan op de referentievloeren. Dit kan als een welzijnsverbetering worden beschouwd.

- De overige dierkenmerken die in het onderzoek zijn vastgelegd met betrekking tot de klinische gezondheid en de technisch prestaties werden niet of nauwelijks beïnvloed door het vloertype. Dit betekent dat de welzijnsverbetering die door de toepassing van een alternatief vloertype wordt bewerkstelligd bij vleeskalveren beperkt van aard is, in tegenstelling tot de effecten die in sommige studies met vleesstieren worden gerapporteerd wanneer de vergelijking wordt gemaakt tussen betonnen roosters en verschillende varianten van rubber. Het ligt voor de hand dat de in vergelijking met vleesstieren kortere mestperiode in combinatie met een aanzienlijk lager (eind)gewicht factoren zijn die vleeskalveren voor een groot deel beschermen tegen negatieve bijeffecten van relatief harde vloeren zoals houten of betonnen roosters.

- Andersom kan ook geconcludeerd worden dat de toepassing van alternatieve vloertypen duidelijk niet tot een verslechtering van de gezondheid of de technische prestaties van de kalveren heeft geleid. Dit wijst erop dat vloertype naar alle waarschijnlijkheid geen effect had op de infectiedruk in vleeskalverstallen.

- Bij blankvleeskalveren nam de mate van bevuiling op het vleeskalverbedrijf enigszins toe wanneer gebruik werd gemaakt van alternatieve vloertypen. Bij rosékalveren ging de huisvesting op Easyfix alleen op 8 weken na aanvang van de afmestfase gepaard met een toename de bevuiling ten opzichte van de referentievloer; dit verschil was 2 weken voor de slacht niet meer aanwezig. Rosékalveren gehuisvest op ICE, daarentegen, waren ten opzichte van de referentievloer wezenlijk schoner. Cruciaal is dat verschillen in bevuiling op het vleeskalverbedrijf geen gevolgen hadden voor de mate van bevuiling van de dieren bij aankomst op het slachthuis. Slechts enkele vrachten - met bovendien kalveren afkomstig van verschillende vloertypen - werden op het slachthuis als vuil beoordeeld.

- In de afdelingen waarin het onderzoek werd uitgevoerd zijn gedurende de volledige duur van de praktijkstudie metingen gedaan aan de temperatuur en de relatieve luchtvochtigheid. Vloertype had op deze waarnemingen geen effect. Dit laat zien dat voor wat betreft de temperatuur en de relatieve luchtvochtigheid het stalklimaat niet door het vloertype werd beïnvloed.

- Kalverhouders zijn gemiddeld genomen tevreden over de zachte vloeren, maar vinden ze gladder en minder veilig dan hun traditionele rooster. Gedragswaarnemingen en objectieve stroefheidsmetingen onderschrijven dit niet.

- De zachte vloeren dragen niet bij aan vermindering van de ammoniakemissie, noch aan verlaging van de geuruitstoot. Toepassing van klepjes in de roosterspleet geeft wel een afname van de ammoniakuitstoot. Met niet optimaal functionerende kleppen werd een reductie van $23 \%$ vastgesteld. Dit is niet voldoende om aan aangekondigde wetgeving te voldoen. er zit echter meer potentieel.

- Er staan geen opbrengsten tegenover de extra investering in zachte vloeren. De meerkosten van de zachte toplagen bedragen 5 - 10 Eurocent per $\mathrm{kg}$ vlees en ingeval de ondervloer ook vervangen moet worden 11 - 15 Eurocent. 


\section{Literatuur}

Absmanner, E., C. Rouha-Mülleder, T. Scharl, F. Leisch en J. Troxler, 2009. Effects of different housing systems on the behaviour of beef bulls - An on-farm assessment on Austrian farms. Appl. Anim. Behav. Sci. 118, 12-19.

Berends, H., J.J.G.C. van den Borne, H. Mollenhorst, C.G. van Reenen, E.A.M. Bokkers en W.J.J. Gerrits, 2014. Utilization of roughages and concentrates relative to that of milk replacer increases strongly with age in veal calves. J. Dairy Sci. 97, 6475-6484.

Beurskens, A.G.C. en J.M.G. Hol. 2004. Onderzoek naar de ammoniak- en geuremissie van stallen LXI. Stal voor vleeskalveren (witvlees productie). A\&F Rapport 220

Bovine Medicine: Disease and Husbandry of Cattle, 1991. Andrews, A.H., R.W. Blowey, H. Boyd en R.G. Eddy (Editors), Wiley-Blackwell.

Brscic, M., F. Gottardo, H. Leruste, J. Lensink, C.G. van Reenen en G. Cozzi, 2011. Prevalance of locomotory system disorders in veal calves and risk factors for occurrence of bursitis. Agric. Consp. Scient. 76, 291-295.

Brscic, M., R. Ricci, P. Prevedello, C. Lonardi, R. De Nardi, B. Contiero, F. Gottardo en G. Cozzi, 2015. Synthetic rubber surface as an alternative to concrete to improve welfare and performance of finishing beef cattle reared on fully slatted flooring. Animal 9, 1386-1392.

Cattle Medicine, 2011. Scott, P.R., C.D. Penny en A. Macrae, CRC Press, 2011, 288 pp.

Cozzi, G., E. Tessitore, B. Contiero, R. Ricci, F. Gottardo en M. Brscic, 2013. Alternative solutions to the concrete fully-slatted floor for the housing of finishing beef cattle: Effects on growth performance, health of the locomotor system and behaviour. Vet. J. 197, 211-215.

De Lauwere, C., W. Schouten, D. Smits en J. Stefanowska, 2004. Oriënterend onderzoek naar het gedrag van vleeskalveren op verschillende vloertypen. Standaard houten roostervloer, houten roostervloer met brede balken en houten roostervloer met rubber toplaag en luchtkamers vergeleken. Agrotechnology \& Food Innovations B.V. Rappoer 238, oktober 2004, 22 pp.

Earley, B., B. McDonnell en E.G. O'Riordan, 2015. Effect of floor type on the performance, physiological and behavioural responses of finishing beef steers. Acta Vet. Scand. 57, 73.

Elmore, M.R.P., M.F. Elischer, M.C. Claeys, en E.A. Pajor, 2015. The effects of different flooring types on the behavior, health, and welfare of finishing beef steers. J. Anim. Sci. 93, 1258-1266.

Graunke, K.L., E. Telezhenko, A. Hessle, C. Bergsten en J.M. Loberg, 2011, Does rubber flooring improve welfare and production in growing bulls in fully slatted floors? Anim. Welfare 20, 173-183.

Gygax, L., C. Mayer, H. Schulze Westerath, K. Friedli en B. Wachsler, 2007. On-farm assessment of the lying behaviour of finishing bulls kept in housing systems with different floor qualities. Anim. Welfare 16, 205-208.

Hol, J.M.G. en C.M. Groenestein. 1997. Praktijkonderzoek naar de ammoniakemissie van stallen XXXI. Verschillende huisvestingssystemen voor vleeskalveren. DLO Rapport 97-1001.

Keane, M.P., M. McGee, E.G. O'Riordan, A.K. Kelly en B. Earley, 2015. Effect of floor type on hoof lesions, dirt score, immune response and production of beef bulls. Livest. Sci. 180, 220-225.

KWIN. 2016. Kwantitatieve Informatie Veehouderij 2016-2017. Wageningen Livestock Research, KWIN Handboek 30

Lowe, D.E., R.W.J. Steen, V.E. Beattie en B.W. Moss, 2001. The effect of floor type system on the performance, cleanliness, carcass composition and meat quality of housed finishing beef cattle. Livest. Prod. Sci. 69, 33-42.

Mollenhorst, H., P.B.M. Berentsen, H. Berends, W.J.J Gerrits en I.J.M. de Boer, 2016. Economic and environmental effects of providing increased amounts of solid feed to veal calves. J. Dairy Sci. 99, 2180-2189.

Ogink, N.W.M., J. Mosquera en J.M.G. Hol. 2013. Protocol voor meting van ammoniakemissie uit huisvestingssystemen in de veehouderij 2013. Rapport 726, Wageningen UR Livestock, Lelystad, The Netherlands.

Ogink, N.W.M.. 2011. Protocol voor meting van geuremissie uit huisvestingssystemen in de veehouderij 2010. Rapport 491, Wageningen UR Livestock, Lelystad, The Netherlands. 
Panivivat, R., E.B. Kegley, J.A. Pennington, D.W. Kellogg en S.L. Krumpelman, 2004. Growth performance and health of dairy calves bedded with different types of materials. J. Dairy Sci. 87, 3736-3745.

Platz, S., F. Ahrens, E. Bahrs, S. Nüske, M.H. Ehrhard, 2007. Association between floor type and behaviour, skin-lesions, and claw dimensions in group-housed fattening bulls. Prev. Vet. Med. 80, 209-221.

Rouhada-Mülleder, C., E. Absmanner, E. Kahrer, H. Zeiner, T. Scharl, L. Fleisch, C. Stanek en J. Troxler, 2012. Aternative housing systems for fattening bulls under Austrian conditions with special respect to rubberised slatted floors. Anim. Welfare 21, 113-126.

Ruis-Heutinck, L.F.M., M.C.J. Smits, A.C. Smits, P.P.H. Kant en J.J. Heeres-van der Tol, 1999. Vloertype en oppervlakte bij vleesstieren. Effect op gedrag, gezondheid, milieu en technische prestaties. Praktijkonderzoek Rundvee, Schapen en Paarden. Publicatie 140, december 1999, 60 pp.

Schulze Westerath, H., L. Gygax, C. Mayer en B.Wechsler, 2007. Leg lesions and cleanliness of finishing bulls kept in housing systems with different lying area surfaces. Vet. J. 174, 77-85. 


\section{Bijlage 1 Deelnemende kalverhouders}

Blankvlees kalverhouders:

1 Dhr. J. Bettink en Dhr. B. Droppert

2 Dhr H. Dibbits

3 Dhr. H. van Dijk

4 Dhr. C. de Jong

5 Dhr. R. Mathijssen

6 Mevr. C. Noordam- v. d. Broek

7 Dhr. B. van Roekel

8 Dhr. H. de Weerd

Rosé kalverhouders:

1 Dhr. R. Beenen

2 Dhr. J. Elderink

3 Dhr. B. Folbert

4 Dhr. H. Lammers

5 Dhr. H Luijerink en mevr. M Luijerink- Hendriksen

6 Dhr. W. Rommens 


\section{Bijlage 2 Samenstelling projectgroep en stuurgroep}

Projectgroep

Peter Mölder

Jacques de Groot

Fije Visscher

Hans Lammers

Dolf Smits

Sjoerd Bokma

Maaike Wolthuis

Kees van Reenen

Jetta Heeres

Denkavit b.v.

Van Drie Group

Vakgroep LTO Vleeskalverhouderij

Vakgroep LTO Vleeskalverhouderij

Dolf Smits Advies

Wageningen Livestock Research

Wageningen Livestock Research (secretaris)

Wageningen Livestock Research

Wageningen Livestock Research (voorzitter)

Stuurgroep

Jan Klaver

Henk Bekman

Erik Buys

Jacques de Groot

Bert van den Berg

Voorheen Productschap Vee en Vlees (PVV), later op persoonlijke titel (voorzitter).

Stichting Brancheorganisatie Kalversector

Denkavit

Van Drie Group

Henk van der Velde

De Dierenbescherming

Wim Thus

Ministerie EZ

Sjoerd Bokma

Voorzitter Vakgroep LTO Vleeskalverhouderij

Wageningen Livestock Research

Kees van Reenen

Jetta Heeres

Wageningen Livestock Research

Wageningen Livestock Research (secretaris) 


\section{Bijlage 3 Vloeren voorstudie}

\begin{tabular}{|c|c|c|}
\hline Blank & Rosé & \\
\hline Hout & Beton & \\
\hline Beton & Hout & \\
\hline $\begin{array}{l}\text { ICE } \\
\text { Comfort Mat slats: } \\
\text { Bolvormige goed indrukbare } \\
\text { zacht kunststofprofielen die } \\
\text { over de roosterbalken } \\
\text { worden vastgeklikt. }\end{array}$ & $\begin{array}{l}\text { ICE } \\
\text { Comfort Mat slats: Bolvormige } \\
\text { goed indrukbare zacht } \\
\text { kunststofprofielen die over de } \\
\text { roosterbalken worden } \\
\text { vastgeklikt. }\end{array}$ & \\
\hline $\begin{array}{l}\text { Easyfix } \\
\text { Slat rubber system: } \\
\text { Licht aflopende rubberen } \\
\text { opleg stroken van } 2 \\
\text { roosterbalken breed, die } \\
\text { door middel van noppen } \\
\text { worden verankerd in de } \\
\text { roosterspleten }\end{array}$ & $\begin{array}{l}\text { Easyfix } \\
\text { Slat rubber system } \\
\text { Licht aflopende rubberen } \\
\text { opleg stroken van } 2 \\
\text { roosterbalken breed, die door } \\
\text { middel van noppen worden } \\
\text { verankerd in de } \\
\text { roosterspleten } \\
\end{array}$ & 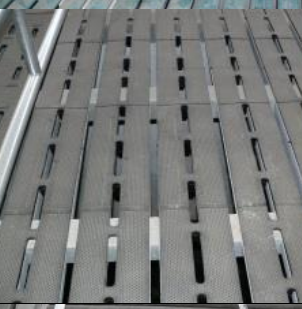 \\
\hline $\begin{array}{l}\text { Van Beek Rubber op } \\
\text { beton } \\
\text { Ongeprofileerde rubbermat } \\
\text { (4 mm dikte) waarin beton } \\
\text { gegoten is. }\end{array}$ & $\begin{array}{l}\text { Van Beek Rubber op beton } \\
\text { Ongeprofileerde rubbermat (4 } \\
\text { mm dikte) waarin beton } \\
\text { gegoten is. }\end{array}$ & 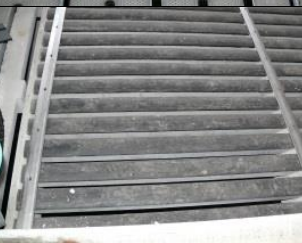 \\
\hline $\begin{array}{l}\text { Van Beek Rubber op hout } \\
\text { Bol hardhouten rooster met } \\
\text { ongeprofileerde rubbermat } \\
\text { ( } 4 \mathrm{~mm} \text { dikte). De } \\
\text { rubberstroken worden } \\
\text { d.m.v. schroeven op het } \\
\text { hardhout bevestigd }\end{array}$ & $\begin{array}{l}\text { Van der Velden Beton } \\
\text { (Ecovloer) } \\
\text { Roosterelementen voorzien } \\
\text { van rubber inserts met } \\
\text { mestdoorlatende gleuven. } \\
\text { met flappen. } 1 / 3 \text { van het } \\
\text { vloeroppervlak is, om } \\
\text { wegglijden tegen te gaan, } \\
\text { uitgevoerd als gegroefd beton } \\
\text { (totale balkbreedte }=9 \mathrm{~cm} \text { ). }\end{array}$ & $\frac{7}{5}=$ \\
\hline & $\begin{array}{l}\text { Kraiburg } \\
\text { Dikke vlakke rubbermat, } \\
\text { welke aangebracht wordt op } \\
\text { de bestaande roostervloer. } \\
\text { Het roosterprofiel wordt op } \\
\text { maat overgenomen in de } \\
\text { matten. Fixatie vindt plaats } \\
\text { door middel van wiggen die in } \\
\text { de roosterspleten worden } \\
\text { aangebracht. }\end{array}$ & \\
\hline
\end{tabular}




\section{Bijlage 4 Vloeren praktijkstudie}

\section{Bolle roostermat met luchtkamers (ICE / Groene Vlag)}

\section{a. Blankvleesbedrijven:}

Beschrijving roostermat:

Bol uitgevoerde, zachte en indrukbare roostermat van thermoplastisch rubber en voorzien van luchtkamers. De mat heeft een werkende breedte van ca $128 \mathrm{~mm}$ en een effectieve spleetbreedte van ca $29 \mathrm{~mm}$. De mat wordt aangebracht op een speciale roostervloer van hout of beton met een nominale balkbreedte van $120 \mathrm{~mm}$ en een spleetbreedte van $37 \mathrm{~mm}$. De roostermat wordt middels stugge zijwangen aan de roosterbalk vastgeklemd.

\section{Beschrijving roostervloer:}

De roostervloer waar de roosterafdekking op wordt aangebracht, kan gemaakt zijn van hout of beton.

- De houten roostervloer heeft balken van ca $120 \times 45 \mathrm{~mm}$ ( $\mathrm{b} \times \mathrm{h}$ ) en een spleetbreedte van $37 \mathrm{~mm}$. Deze vloer heeft de beperking dat daarop geen matten kunnen worden gemonteerd waar (later) alsnog emissie reducerende afsluitklepjes kunnen worden bevestigd.

- De betonroostervloer heeft balken van ca 120 x tenminste $120 \mathrm{~mm}$ (b x h) en een spleetbreedte van $37 \mathrm{~mm}$. De zijkanten van de balk moeten over een lengte van tenminste $70 \mathrm{~mm}$ onder een hoek van 11 - 16 graden naar binnen lopen. Het bovenste gedeelte van de zijkanten mag over een lengte van maximaal $20 \mathrm{~mm}$ verticaal zijn. Op deze roostervloer worden roostermatten aangebracht die voorbereid zijn op het aanbrengen van afsluitklepjes.

\section{b. Rosé bedrijven:}

\section{Beschrijving roostermat:}

Bol uitgevoerde, zachte en indrukbare roostermat van thermoplastisch rubber en voorzien van luchtkamers. De mat heeft een werkende breedte (afgestemd op een ondervloer) van $127-138 \mathrm{~mm}$ en een effectieve spleetbreedte van ca $30 \mathrm{~mm}$. De roostermat wordt aangebracht op een bestaande of nieuwe roostervloer van beton met een vaste spleetbreedte van $38 \mathrm{~mm}$ en een variabele balkbreedte van 119 tot $130 \mathrm{~mm}$. De roostermat wordt middels stugge zijwangen aan de betonroosterbalk vastgeklemd.

\section{Beschrijving roostervloer:}

- De betonroostervloer heeft balken met een minimum breedte van $119 \mathrm{~mm}$ en een maximum breedte van $130 \mathrm{~mm}$. De spleetbreedte bedraagt $38 \mathrm{~mm}$. De zijkanten van de balk moeten over een lengte van tenminste $70 \mathrm{~mm}$ onder een hoek van 11 - 16 graden naar binnen lopen. Het bovenste gedeelte van de zijkanten mag over een lengte van maximaal $20 \mathrm{~mm}$ verticaal zijn. Op deze roostervloer worden roostermatten aangebracht die voorbereid zijn op het kunnen aanbrengen van afsluitklepjes.

- Voor bestaande betonroosters met een spleetbreedte van minder dan $38 \mathrm{~mm}$ is er de mogelijkheid om deze mechanisch op te frezen naar $38 \mathrm{~mm}$. Of het rooster hiervoor geschikt is wordt door de leverancier van de matten beoordeeld. 


\section{Bolle, massief rubberen duo-roostermat (Easyfix / Gold Standard)}

\section{a. Blankvleesbedrijven:}

Beschrijving roostermat:

Roostermat van natuurlijk rubber met een werkende effectieve (balk)breedte van $120 \mathrm{~mm}$ en een spleetbreedte van $30 \mathrm{~mm}$. De roostermat worden geproduceerd als duo-mat waarmee twee roosterbalken worden afgedekt. Deze zijn in het midden door middel van bruggen met elkaar verbonden, De bruggen zijn aan de onderzijde voorzien van rubber pluggen waarmee de mat in de roosterspeet wordt vastgeklemd. Het oppervlak van de mat is in het midden van de roosterbalk bol en zonder profilering. Langs de beide zijden licht aflopend en voorzien van een hamerslagprofiel. Haaks op de lengterichting is om de $40 \mathrm{~cm}$ een $3 \mathrm{~mm}$ hoge rubber strip op de mat aangebracht om extra grip te realiseren. Aan de zijkanten zorgt een overhangende rubber slab van $15 \mathrm{~mm}$ voor een afscherming van de overgang van de mat op het onderliggende rooster. De onderzijde van de mat is voorzien van een zaagtand-profiel om de indrukbaarheid te vergroten.

Beschrijving roostervloer:

De roostervloer waar de duo-mat op wordt gemonteerd kan gemaakt zijn van hout of beton.

- De houten roostervloer heeft balken van ca $110 \times 45 \mathrm{~mm}$ ( $\mathrm{b} \times \mathrm{h}$ ) en een spleetbreedte van $40 \mathrm{~mm}$. In deze vloer kunnen voorzieningen zijn aangebracht waarmee het mogelijk is om emissiereducerende flappen te plaatsen

- De betonroostervloer heeft balken van ca $110 \mathrm{~mm}$ breed en een spleetbreedte van $40 \mathrm{~mm}$. In de roosterbalken kunnen voorzieningen zijn aangebracht waarmee het mogelijk is om emissiereducerende flappen te plaatsen.

\section{b. Rosé bedrijven:}

\section{Beschrijving roostermat:}

Roostermat van natuurlijk rubber met een werkende (balk)breedte van minimaal $129 \mathrm{~mm}$ en maximaal $140 \mathrm{~mm}$ en een vaste spleetbreedte van $28 \mathrm{~mm}$. De matten worden geproduceerd als duomat waarmee twee roosterbalken worden afgedekt. Deze zijn in het midden door middel van bruggen met elkaar verbonden, De bruggen zijn aan de onderzijde voorzien van rubber pluggen waarmee de mat in de roosterspeet wordt vastgeklemd. Het oppervlak van de mat is in het midden van de roosterbalk bol en zonder profilering. Langs de beide zijden licht aflopend en voorzien van een hamerslagprofiel. Haaks op de lengterichting is om de $40 \mathrm{~cm}$ een $3 \mathrm{~mm}$ hoge rubber strip op de mat aangebracht om extra grip te realiseren. Aan de zijkanten zorgt een overhangende rubber slab van 15 $\mathrm{mm}$ voor een afscherming van de overgang van de mat op het onderliggende rooster. De onderzijde van de mat is voorzien van een zaagtand-profiel om de indrukbaarheid te vergroten.

\section{Beschrijving roostervloer:}

De roostervloer waar de mat voor rosékalveren op wordt gemonteerd kan een bestaand gangbaar betonrooster of een nieuw betonrooster zijn:

- Bestaande betonroosters moeten voldoen aan de volgende voorwaarden: een vaste spleetbreedte van $38 \mathrm{~mm}$ en een balkbreedte van 119 tot maximaal $130 \mathrm{~mm}$. Het is bij bestaande roosters niet mogelijk om later alsnog emissie reducerende flappen aan te brengen. De leverancier beoordeelt of voor de bestaande roostervloer een bijpassende mat kan worden geleverd.

- Voor bestaande betonroosters met een spleetbreedte van minder dan $38 \mathrm{~mm}$ is er de mogelijkheid om deze mechanisch op te frezen naar $38 \mathrm{~mm}$. Of het rooster hiervoor geschikt is wordt door de leverancier van de matten beoordeeld. 


\section{Foto's}
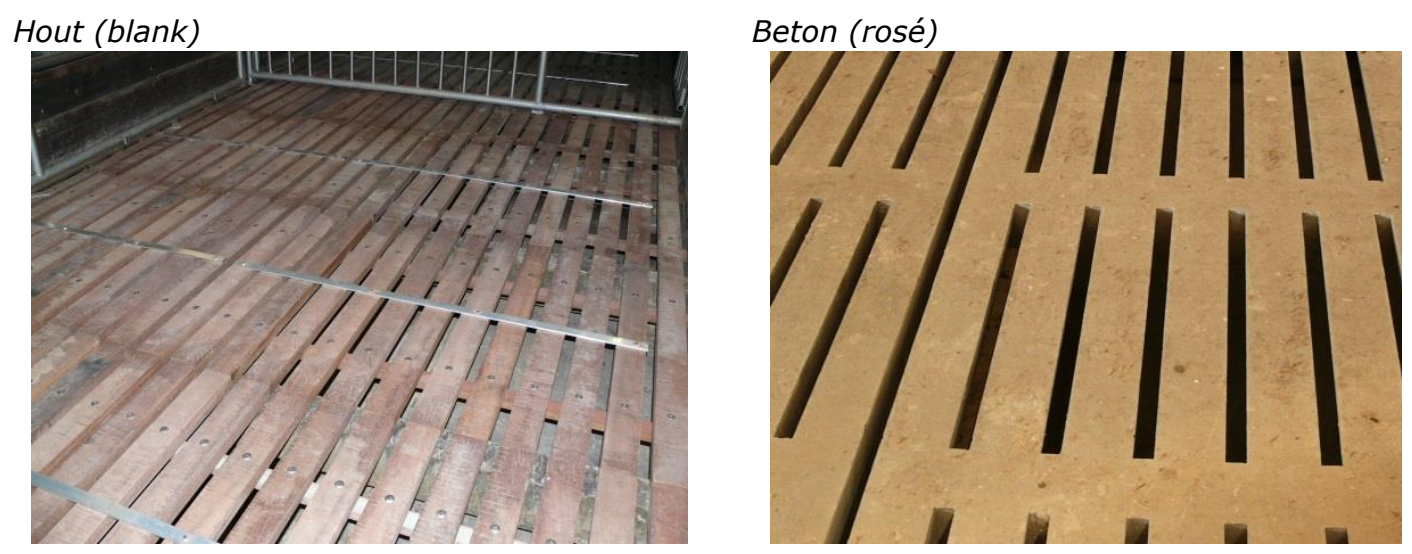

Easyfix

ICE

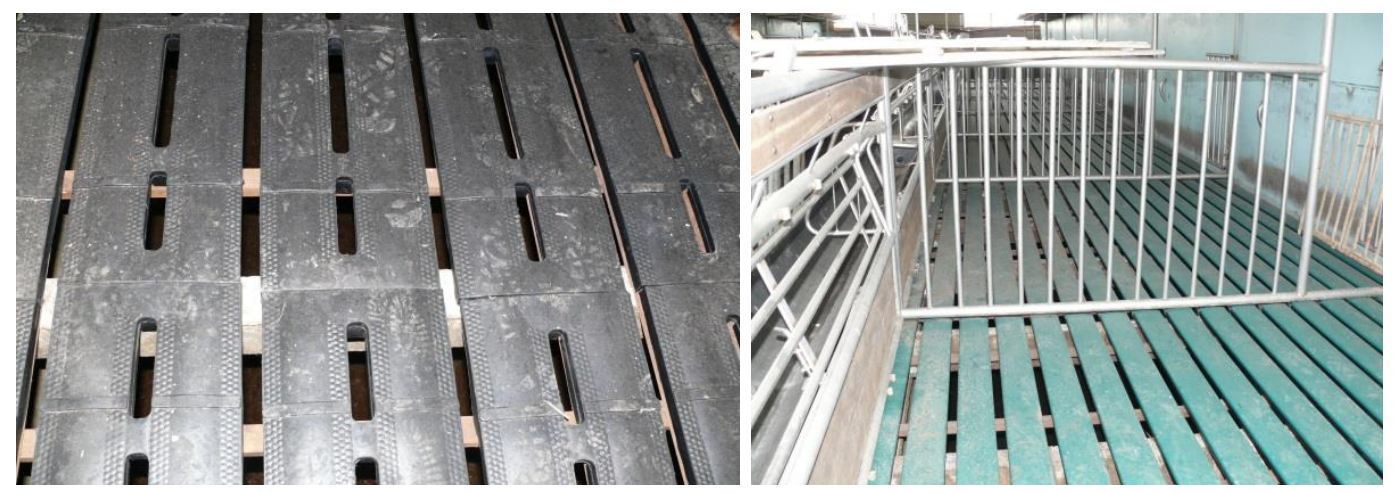

\section{ICE+ flap}

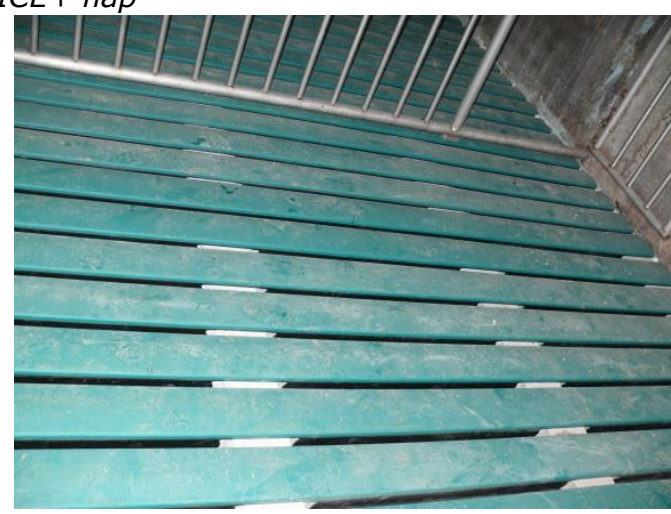

\section{ICE +flap detail}

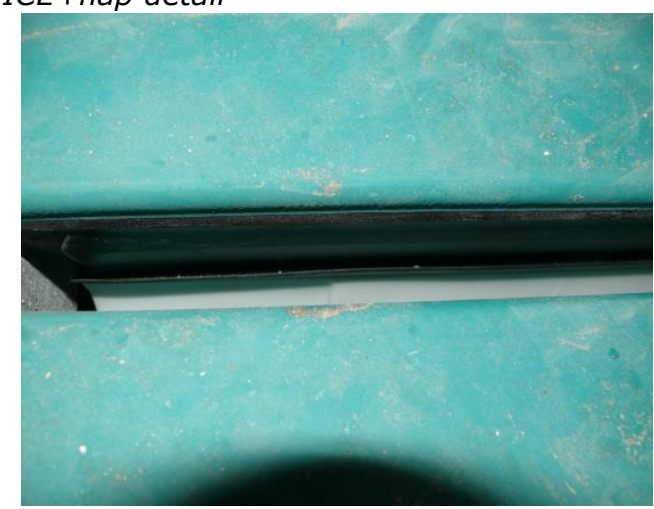




\section{Bijlage 5 Protocol klinische gezondheid}

Kalveren worden beoordeeld op:

Kreupelheid:

Klauwproblemen:

Gewrichtsprobleem:

Verkregen slijmbeurs:

Schimmelinfectie:

Achterblijvers:

Natte vacht:

Dof/Dorre vacht:

Diarree:

Slecht verteerde mest:

Aangebeten staart:
Nee/ Ja, lichte kreupelheid (alle kalveren die niet rad lopen) / Ja, ernstig kreupel (belast 1 of meerdere poten niet)

$\mathrm{Nee} / \mathrm{Ja}$

Nee/ Ja

Nee/ Ja

Nee/ Ja

Nee/ Ja, 15-30\% achterstand/ Ja, >30\% achterstand

Nee/ Ja

Nee/ Ja

Nee/ Ja

$\mathrm{Nee} / \mathrm{Ja}$

Nee/ Ja

Daarbij wordt na afloop van de klinische inspectie de volgende anamnese afgenomen:

\begin{tabular}{|c|c|c|c|}
\hline Nr. & Vraag & \multicolumn{2}{|c|}{ Omschrijving } \\
\hline 7 & $\begin{array}{l}\text { Is er op dit moment sprake van een medicamenteuze } \\
\text { koppel behandeling? (indien van belang toelichten bij } \\
\text { werkblad opmerkingen) }\end{array}$ & $\begin{array}{l}\circ \\
\circ\end{array}$ & $\begin{array}{l}\mathrm{Ja} \\
\mathrm{Nee}\end{array}$ \\
\hline 11 & Hoeveel kalveren zijn er van de melk af? & \multicolumn{2}{|c|}{ Aantal invullen } \\
\hline 12 & Zijn er urinedrinkers in het koppel? & $\begin{array}{ll} \\
\\
\end{array}$ & $\begin{array}{l}\mathrm{Ja} \\
\mathrm{Nee}\end{array}$ \\
\hline 12 & $\begin{array}{l}\text { Worden de urinedrinkers uit de groep gehaald } \\
\text { (geïsoleerd)? }\end{array}$ & $\begin{array}{l}+0 \\
\end{array}$ & $\begin{array}{l}\mathrm{Ja} \\
\mathrm{Nee}\end{array}$ \\
\hline 13 & $\begin{array}{l}\text { Hoe is de melkopname (naar mening van de } \\
\text { kalverenhouder) van het koppel op dit moment? }\end{array}$ & \multicolumn{2}{|c|}{$\begin{array}{l}\text { oGoed } \\
\text { oMatig } \\
\text { oSlecht }\end{array}$} \\
\hline 14 & $\begin{array}{l}\text { Hoe is de ruwvoeropname (naar mening van de } \\
\text { kalverenhouder) van het koppel op dit moment? }\end{array}$ & \multicolumn{2}{|c|}{$\begin{array}{l}\text { oGoed } \\
\text { oMatig } \\
\text { oSlecht }\end{array}$} \\
\hline 15 & $\begin{array}{l}\text { Op welk tijdstip was de laatste melkgift vóór de } \\
\text { monitoring (dit bezoek)? }\end{array}$ & \multicolumn{2}{|c|}{$\begin{array}{l}\text { Uurnotatie van kloktijd noteren (daarbij } \\
\text { afronden naar beneden, bijvoorbeeld 9:55 } \\
\text { wordt 9) }\end{array}$} \\
\hline 16 & $\begin{array}{l}\text { Op welk tijdstip was de laatste ruwvoergift vóór de } \\
\text { monitoring? }\end{array}$ & \multicolumn{2}{|c|}{$\begin{array}{l}\text { Uurnotatie van kloktijd noteren (daarbij } \\
\text { afronden naar beneden) }\end{array}$} \\
\hline 17 & $\begin{array}{l}\text { Wat voor soort ruwvoer wordt er voornamelijk } \\
\text { verstrekt? (indien meerdere items ongeveer gelijke } \\
\text { hoeveelheden of indien anders (niet genoemd bij de } \\
\text { opties) > mengsels) }\end{array}$ & $\begin{array}{l} \\
0 \\
0 \\
\circ \\
0\end{array}$ & $\begin{array}{l}\text { Snijmais } \\
\text { Gerst } \\
\text { Ruwvoerbrok } \\
\text { Stro } \\
\text { Mengsels } \\
\end{array}$ \\
\hline 18 & $\begin{array}{l}\text { Hoeveel ruwvoer (in grammen, NIET in droge stof) } \\
\text { wordt er per kalf gemiddeld op dit moment gevoerd? } \\
\text { (kies best passende optie) }\end{array}$ & $\begin{array}{l} \\
0 \\
0 \\
0 \\
0 \\
0 \\
0\end{array}$ & $\begin{array}{l}0-99 \\
100-199 \\
200-499 \\
500-999 \\
>1000 \\
\text { Ad lib } \\
\end{array}$ \\
\hline 19 & $\begin{array}{l}\text { Is deze ruwvoer gift volgens schema ? (indien van } \\
\text { belang toelichten bij werkblad opmerkingen) }\end{array}$ & $\begin{array}{l}\circ \\
\circ\end{array}$ & $\begin{array}{l}\mathrm{Ja} \\
\mathrm{Nee}\end{array}$ \\
\hline
\end{tabular}

Data wordt met behulp van een PDA genoteerd en naar de ASG opgestuurd. 


\section{Bijlage 6 Protocol pathologie longen}

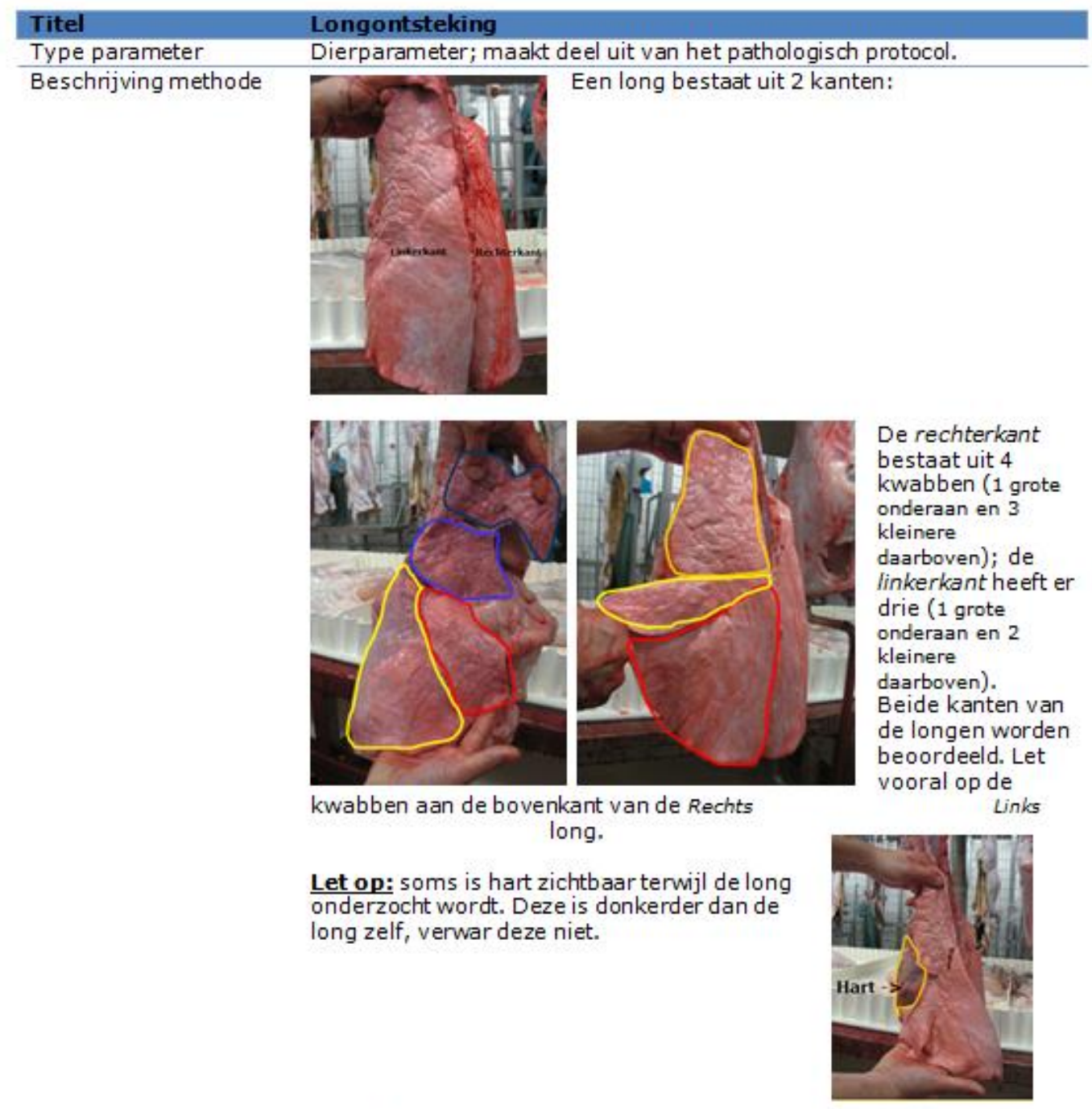

Hoe herken je een long met longontsteking?

Een normale long (groen omcirkeld) heeft een bleke oranje kleur. Een long met longontsteking (rood omairkeld) heeft rood-grijze kleurafwijkingen:

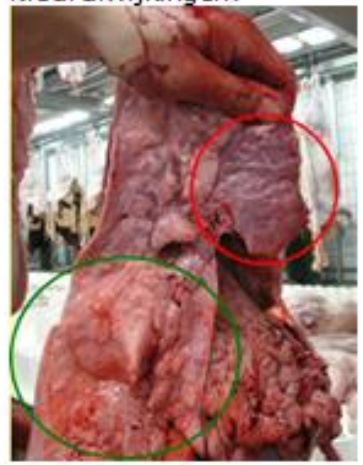


Beoordeel in het slachthuis per bedrijf 200 longen volgens de beschreven methodiek op longontsteking.

\section{Individueel niveau:}

0 : Geen veranderingen

1: Minimaal; 1 centrale ontstekingshaard

2: $\quad$ Mild tot gemiddeld; 1 meer uitgebreide of meerdere kleine

ontstekingshaard(en) beperkt tot 1 kwab perlong kant.

3: Ernstig; aanwezigheid van bindweefsel verklevingen op of tussen de longkwabben.

\section{Bedrijfsniveau:}

Percentage longen met minimaal, mild en ernstige longontsteking

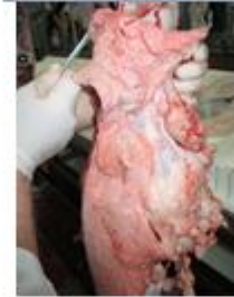

Score 0

Geen verkleuringen

Geen verkleuringe

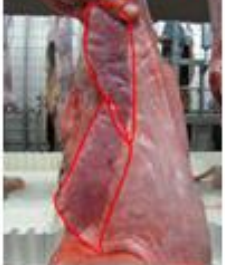

Score 3

Een ernstige beschadigde long treft 1 of meerdere longkwabben (in dit geval 2) en laat soms ( $2^{\text {da }}$ foto)

abcessen zien

(5) Wageningen UR Livestock Research

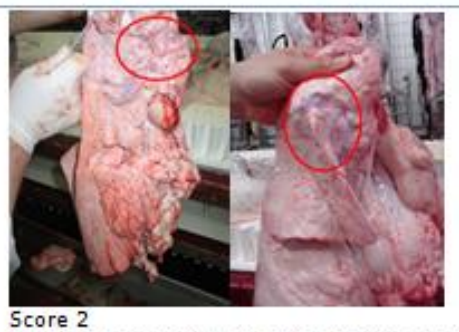

Score 2

Meerdere ontstekingshaarden (foto 1 en 2)
Abscess=round cavity filled with pus

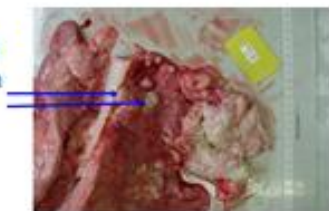

Titel

Type parameter Pleuritis

Beschrijving methode Pleuritis is een borstvliesontsteking. Bij een normale long kunnen de

kwabben van elkaarworden gescheiden. Bijeen long met pleuritis kleeft het oppervlakte van de kwab aan andere kwabben of organen.

Beoordeel in het slachthuis per bedrijf 200 longen volgens de beschreven methodiek op pleuritis.

Individueel niveau:

0 - Long zonder pleuritis

1 - Long met pleuritis

Classificatie Bedrijfsniveau:

Percentage longen met pleuritis

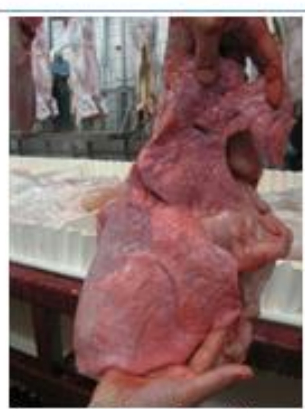

Score 0: Geen pleuritis

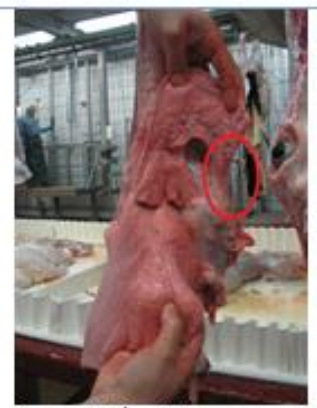

Score 1: Pleuritis

In dit geval is het oppervlakte van een kwab

vastgekleefd aan het weefsel rondom het hart 


\section{Bijlage 7 Protocol bevuiling}

De bevuiling van het kalf wordt op twee leeftijden beoordeeld, resp. op 10 weken na opzetten en 2 weken vóór het slachten.

Het kalf wordt beoordeeld op (zie ook figuur hieronder):

Buik: totale buik

Zijkant: hele zijkant tot aan ruggenwervel

Achterhand: hele achterhand tot aan de hak

Achterpoot: klauw tot en met de hak

Voorpoot: klauw tot aan knie

Knie: alleen de knie

Voorhand: hele voorhand tot de knie

Hals/Kop: totale hals en kop

Met uitzondering van de buik en hals/kop wordt zowel de linker als de rechterkant beoordeeld. Elk onderdeel wordt beoordeeld volgens de onderstaande score:

0 : $\quad<25 \%$ van het te beoordelen gebied is bevuild.

1: $\quad>25 \%$ van het te beoordelen gebied is bevuild.

De maximale score per kalf is 14 .
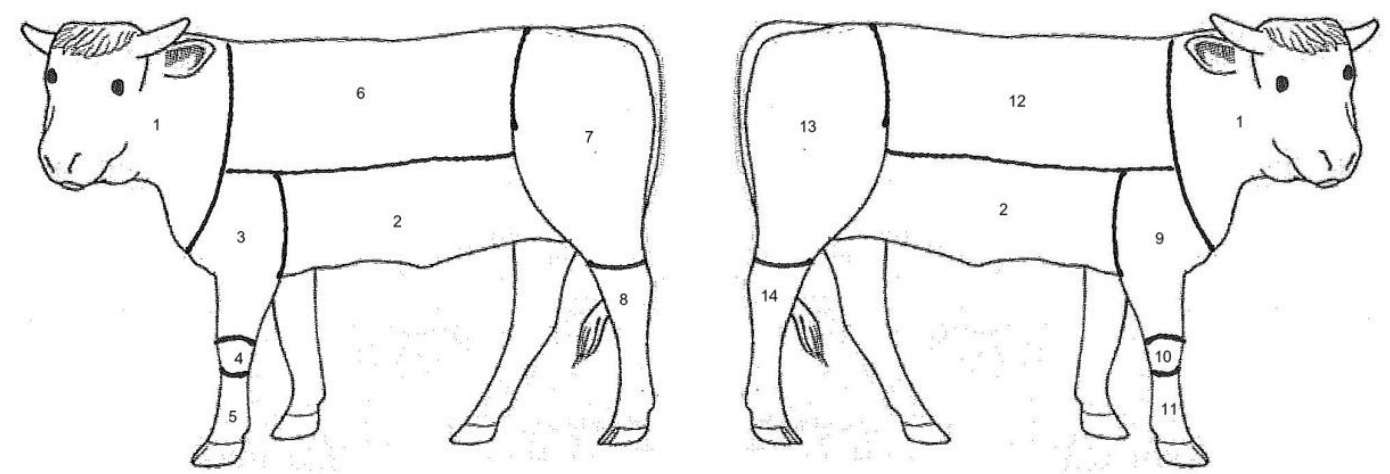

Kalf opgedeeld in 14 deelgebieden, welke afzonderlijk beoordeeld wordt op bevuiling. 


\section{Bijlage 8 Overige resultaten praktijkstudie}

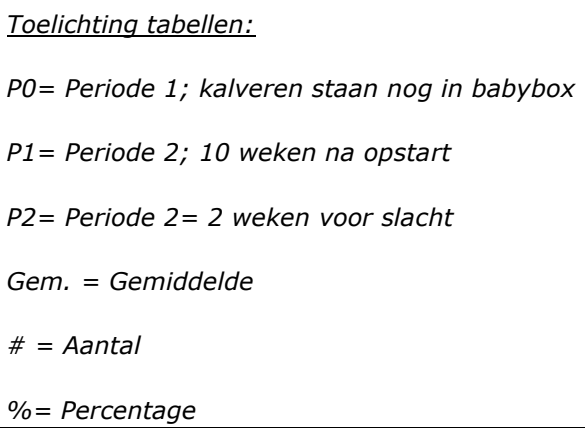

\section{Blankvleeskalveren}

Bevuiling kalveren

\begin{tabular}{|l|c|c|c|c|c|c|c|c|c|}
\cline { 2 - 10 } \multicolumn{1}{c|}{} & \multicolumn{2}{c|}{ Referentie } & \multicolumn{3}{c|}{ Easyfix } & \multicolumn{3}{c|}{ ICE } \\
\cline { 2 - 10 } & P0 & P1 & P2 & P0 & P1 & P2 & P0 & P1 & P2 \\
\hline Gem. \% bevuilde buik & 0.1 & 0.7 & 2.2 & 0.3 & 10.8 & 6.0 & 0.3 & 30 & 5.2 \\
\hline Gem. bevuilingsscore & 2.3 & 1.5 & 8.6 & 5.1 & 4.8 & 18.7 & 5.7 & 5.3 & 14.2 \\
\hline
\end{tabular}

$\underline{\text { Klinische observaties }}$

\begin{tabular}{|l|c|c|c|c|c|c|}
\cline { 2 - 7 } \multicolumn{2}{|c|}{} & \multicolumn{2}{|c|}{ Referentie } & \multicolumn{2}{c|}{ Easyfix } & \multicolumn{2}{c|}{ ICE } \\
\cline { 2 - 7 } & P1 & P2 & P1 & P2 & P1 & P2 \\
\hline \multirow{2}{*}{ Gem. \% licht kreupel } & 0.3 & 0.2 & 0 & 0 & 0.1 & 0.2 \\
\hline Gem. \% ernstig kreupel & 0.1 & 0.1 & 0.1 & 0.1 & 0.2 & 0 \\
\hline Gem. \% klauwproblemen & 0 & 0 & 0 & 0 & 0 & 0.1 \\
\hline Gem. \% gewrichtsproblemen & 0.3 & 0.1 & 0.1 & 0.1 & 0.2 & 0 \\
\hline Gem. \% verkregen slijmbeurs & 0.7 & 6.0 & 0.3 & 1.4 & 0.2 & 0.9 \\
\hline Gem. \% huidbeschadigingen & 4.0 & 1.2 & 3.1 & 2.0 & 3.3 & 3.3 \\
\hline Gem. \% achterstand conditie 15 30\% & 1.2 & 2.5 & 1.3 & 1.7 & 0.6 & 2.1 \\
\hline Gem. \% achterstand conditie 30\% & 0 & 0.1 & 0 & 0.4 & 0.2 & 0.3 \\
\hline Gem. \% natte vacht & 1.3 & 3.3 & 1.3 & 2.0 & 2.4 & 2.8 \\
\hline Gem. \% dorre vacht & 0.2 & 0.3 & 0.4 & 0.7 & 0.4 & 1.0 \\
\hline Gem. \% slecht verteerde mest & 0.6 & 0.5 & 0.8 & 1.1 & 1.0 & 0.2 \\
\hline Gem. \% aangebeten staart & 0.1 & 0 & 0 & 0 & 0 & 0 \\
\hline
\end{tabular}




\begin{tabular}{|l|c|c|c|c|c|c|}
\cline { 2 - 7 } \multicolumn{1}{c|}{} & \multicolumn{2}{c|}{ Referentie } & \multicolumn{2}{c|}{ Easyfix } & \multicolumn{2}{c|}{ ICE } \\
\cline { 2 - 7 } \multicolumn{1}{c|}{} & $\boldsymbol{P 1}$ & $\boldsymbol{P 2}$ & $\boldsymbol{P 1}$ & $\boldsymbol{P 2}$ & $\boldsymbol{P 1}$ & $\boldsymbol{P 2}$ \\
\hline \multirow{2}{*}{ Gem. \# vallen } & 0 & 0 & 0 & 0 & 0 & 0 \\
\hline Gem. \# uitglijden & 2.5 & 2.4 & 3.1 & 1.0 & 3.5 & 3.4 \\
\hline Gem. \# bespringen & 0.2 & 0.3 & 0.3 & 0.6 & 0.3 & 0.6 \\
\hline Gem. \# vechten & 0.7 & 0.5 & 0.8 & 0.5 & 0.6 & 0.6 \\
\hline $\begin{array}{l}\text { Gem. \% uirtelen } \\
\text { aantal gedragingen }\end{array}$ & 0.6 & 0.4 & 1.5 & 0.5 & 0.9 & 0.4 \\
\hline
\end{tabular}

Waarnemingen slachthuis

\begin{tabular}{|l|c|c|c|}
\cline { 2 - 4 } \multicolumn{1}{c|}{} & Referentie & Easyfix & ICE \\
\hline Gem. \% onbeschadigde longen & 47.8 & 47.0 & 48.9 \\
\hline Gem. \%minimaal aangetaste longen & 33.5 & 33.2 & 31.6 \\
\hline Gem.\% mild aangetaste longen & 12.6 & 12.8 & 13.0 \\
\hline Gem. \% ernstig beschadigde longen & 5.8 & 6.3 & 7.4 \\
\hline Gem. \% aangetaste longen & 51.9 & 52.3 & 51.5 \\
\hline Gem \% pleuritis & 34.0 & 32.9 & 38.1 \\
\hline Gem. longscore & 0.8 & 0.8 & 0.8 \\
\hline
\end{tabular}

$\underline{\text { Uitval en antibiotica }}$

\begin{tabular}{|l|c|c|c|}
\hline \multicolumn{1}{l|}{} & Referentie & Easyfix & ICE \\
\hline Gem. \% Uitval & 2.5 & 2.4 & 2.8 \\
\hline Gem..\# individuele behandelingen per kalf & 0.6 & 0.7 & 0.7 \\
\hline Gem. \# koppelbehandelingen & 1.1 & 1.2 & 1.2 \\
\hline Gem. \# dagen koppelbehandeling & 4.5 & 4.6 & 4.5 \\
\hline Gem. \# kalveren individueel behandeld (\% van koppel) & 22.2 & 22.4 & 22.0 \\
\hline Gem.\# behandelingen per individueel. behandeld kalf & 30.0 & 31.0 & 31.0 \\
\hline Gem. aantal behandeldagen per individueel behandeld. kalf & 1.7 & 1.9 & 2.0 \\
\hline
\end{tabular}

Gewichten

\begin{tabular}{|l|c|c|c|}
\cline { 2 - 4 } \multicolumn{1}{c|}{} & Referentie & Easyfix & ICE \\
\hline Gem. start karkasgewicht & 22.2 & 22.3 & 22.1 \\
\hline Gem. slachtgewicht & 149.0 & 148.6 & 147.5 \\
\hline Gem. mestduur & 190.1 & 189.6 & 189.6 \\
\hline
\end{tabular}

\section{Rosé kalveren}

Bevuiling kalveren

\begin{tabular}{|l|c|c|c|c|c|c|}
\cline { 2 - 7 } \multicolumn{1}{c|}{} & \multicolumn{2}{c|}{ Referentie } & \multicolumn{2}{c|}{ Easyfix } & \multicolumn{2}{c|}{ ICE } \\
\cline { 2 - 7 } \multicolumn{1}{c|}{} & P1 & P2 & P1 & P2 & P1 & P2 \\
\hline Gem. \% bevuilde buik & 8.2 & 13.6 & 5.9 & 7.8 & 1.7 & 1.5 \\
\hline Gem. bevuilingsscore & 14.8 & 24.5 & 20.6 & 24.9 & 11.7 & 17.2 \\
\hline
\end{tabular}




\begin{tabular}{|l|c|c|c|c|c|c|}
\cline { 2 - 6 } & \multicolumn{2}{|c|}{ Referentie } & \multicolumn{2}{c|}{ Easyfix } & \multicolumn{2}{c|}{ ICE } \\
\cline { 2 - 7 } & $\boldsymbol{P 1}$ & $\boldsymbol{P 2}$ & $\boldsymbol{P 1}$ & $\boldsymbol{P 2}$ & $\boldsymbol{P 1}$ & $\boldsymbol{P 2}$ \\
\hline Gem. \% licht kreupel & 0.2 & 0.4 & 0 & 0 & 0 & 0.2 \\
\hline Gem. \% ernstig kreupel & 0 & 0.1 & 0 & 0 & 0 & 0.1 \\
\hline Gem. \% klauwproblemen & 0 & 0.1 & 0 & 0 & 0 & 0 \\
\hline Gem. \% gewrichtsproblemen & 0.1 & 0.1 & 0 & 0.1 & 0 & 0.2 \\
\hline Gem. \% verkregen slijmbeurs & 2.8 & 5.7 & 0.7 & 1.6 & 0.6 & 0.8 \\
\hline Gem. \% huidbeschadigingen & 14.3 & 1.0 & 15.4 & 3.8 & 11.3 & 1.1 \\
\hline Gem. \% achterstand conditie 15 30\% & 5.3 & 2.9 & 4.8 & 3.4 & 4.5 & 3.5 \\
\hline Gem. \% achterstand conditie 30\% & 1.0 & 1.0 & 0.9 & 0.8 & 0.8 & 0.7 \\
\hline Gem. \% natte vacht & 0.7 & 0.1 & 0.9 & 0.4 & 0.4 & 0 \\
\hline Gem. \% dorre vacht & 1.8 & 1.3 & 1.5 & 1 & 1.8 & 0.8 \\
\hline Gem. \% slecht verteerde mest & 0 & 0 & 0 & 0 & 0 & 0 \\
\hline Gem. \% aangebeten staart & 0 & 0 & 0 & 0 & 0 & 0 \\
\hline
\end{tabular}

Gedrag

\begin{tabular}{|l|c|c|c|c|c|c|}
\cline { 2 - 7 } \multicolumn{1}{c|}{} & \multicolumn{2}{c|}{ Referentie } & \multicolumn{2}{c|}{ Easyfix } & \multicolumn{2}{c|}{ ICE } \\
\cline { 2 - 7 } \multicolumn{1}{c|}{} & $\boldsymbol{P 1}$ & $\boldsymbol{P 2}$ & $\boldsymbol{P 1}$ & $\boldsymbol{P 2}$ & $\boldsymbol{P 1}$ & $\boldsymbol{P 2}$ \\
\hline Gem. \# vallen & 0 & 0 & 0 & 0 & 0 & 0 \\
\hline Gem. \# uitglijden & 0.3 & 0.5 & 0.4 & 1 & 0.6 & 0.9 \\
\hline Gem. \# bespringen & 0.3 & 0.5 & 0.2 & 1.1 & 0.3 & 0.6 \\
\hline Gem. \# vechten & 0.3 & 0.7 & 0.4 & 0.9 & 0.5 & 0.6 \\
\hline Gem. \# dartelen & 0.3 & 0.3 & 0.3 & 0.3 & 0.4 & 0.3 \\
\hline $\begin{array}{l}\text { Gem. \% uitglijden t.o.v. totaal } \\
\text { aantal gedragingen }\end{array}$ & 26.9 & 27.8 & 41.2 & 40.2 & 49.4 & 41.8 \\
\hline
\end{tabular}

Waarnemingen slachthuis

\begin{tabular}{|l|c|c|c|}
\cline { 2 - 4 } \multicolumn{1}{c|}{} & Referentie & Easyfix & ICE \\
\hline Gem. \% onbeschadigde longen & 32.4 & 28 & 25.8 \\
\hline Gem. \%minimaal aangetaste longen & 32.8 & 32.3 & 35.3 \\
\hline Gem.\% mild aangetaste longen & 16.4 & 18.8 & 21.3 \\
\hline Gem. \% ernstig beschadigde longen & 18.1 & 18.1 & 17.0 \\
\hline Gem. \% aangetaste longen & 67.3 & 69 & 73.6 \\
\hline Gem \% pleuritis & 51.8 & 53.5 & 57.1 \\
\hline Gem. longscore & 1.2 & 1.3 & 1.3 \\
\hline
\end{tabular}


$\underline{\text { Uitval en antibiotica }}$

\begin{tabular}{|l|c|c|c|}
\hline \multicolumn{1}{l|}{} & Referentie & Easyfix & ICE \\
\hline Gem. \% Uitval & 2.5 & 1.8 & 1.7 \\
\hline Gem..\# individuele behandelingen per kalf & 0.1 & 0 & 0.1 \\
\hline Gem. \# koppelbehandelingen & 0.1 & 0.1 & 0.1 \\
\hline Gem. \# dagen koppelbehandeling & 0 & 0 & 0 \\
\hline Gem. \# kalveren individueel behandeld (\% van koppel) & 0 & 0 & 0 \\
\hline Gem.\# behandelingen per individueel. behandeld kalf & 7 & 6 & 6 \\
\hline Gem. aantal behandeldagen per individueel behandeld. kalf & 1.2 & 1.2 & 1.2 \\
\hline
\end{tabular}

$\underline{\text { Gewichten }}$

\begin{tabular}{|l|c|c|c|}
\cline { 2 - 4 } \multicolumn{1}{c|}{} & Referentie & Easyfix & ICE \\
\hline Gem. start karkasgewicht & 44.9 & 49.1 & 45.0 \\
\hline Gem. slachtgewicht & 178.1 & 179.5 & 179.4 \\
\hline Gem. mestduur & 189.4 & 178.8 & 187.8 \\
\hline
\end{tabular}




\section{Bijlage 9 Foto's ondervloer na weghalen toplagen}

\section{Easyfix:}

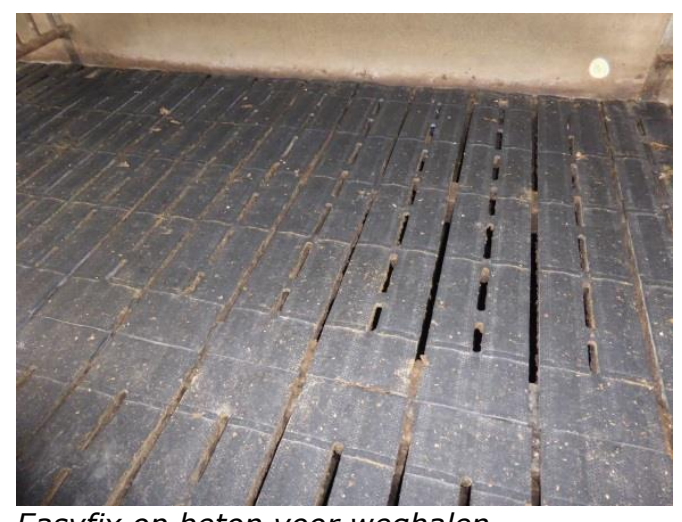

Easyfix op beton voor weghalen

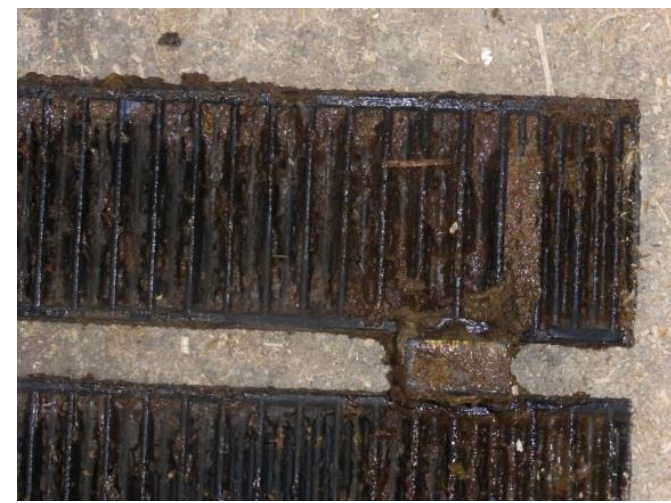

Detailfoto's onderkant Easyfix vloer

ICE:

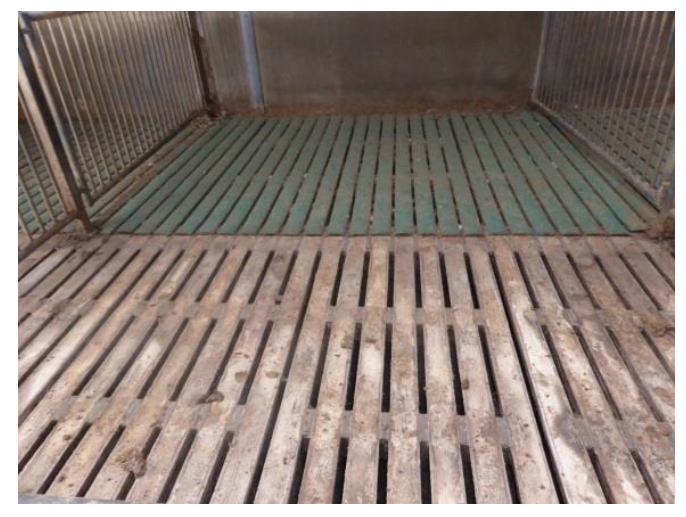

Droge ondervloer bij ICE

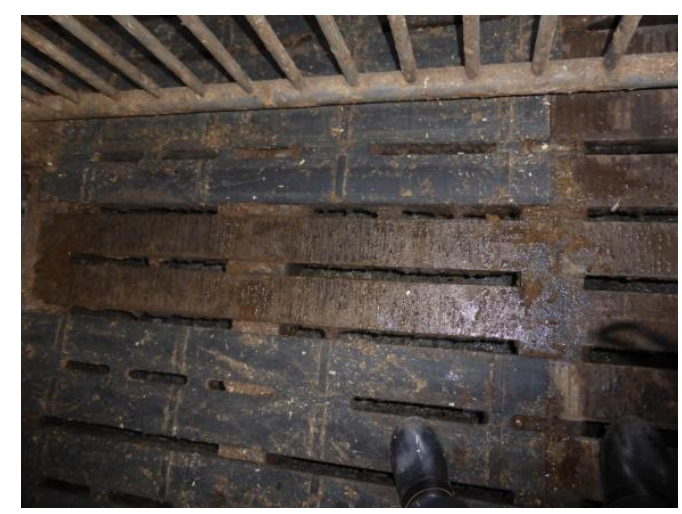

Mest onder de vloer
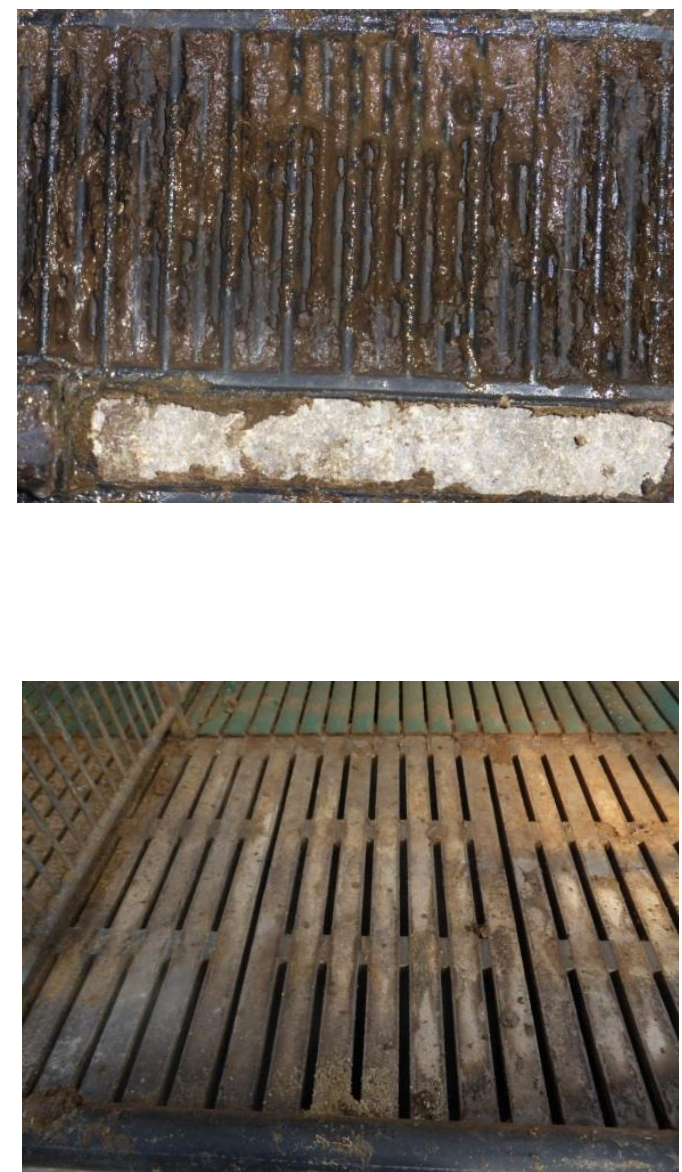

Weinig tot geen mest onder de vloer 


\section{Bijlage 10 Tribo rapportage}

$\begin{aligned} & \text { Aveco de Bondt } \\ \text { bezoekadres } & \text { Podium } 9 \\ \text { postbus } & 2674 \\ \text { postcode } & 3800 \text { GE Amersfoort } \\ \text { telefoon } & (0) 881866010 \\ \text { e-mail } & \text { info@avecodebondt.nl }\end{aligned}$

Rapport

Onderzoek stroefheid met TRIBO-meter op roostervloerelementen van 2 vleeskalverstallen

projectnaam TRIBO metingen op roostervloerelementen van vleeskalverstallen in Overdinkel en Ede

projectnummer 161866

referentie R-TWs/01/161866

opdrachtgever Wageningen UR Livestock Research

postadres Postbus 338

$6700 \mathrm{AH}$ Wageningen

contactpersoon K. Blanken

status Definitief

versie 01

aantal pagina's 9

datum 17 november 2016

auteur T. Welmers

paraaf

gecontroleerd M. Nagelhout 


\section{INHOUDSOPGAVE}

1 INLEIDING

3

2 METHODE VAN ONDERZOEK

2.1 Meetmethode TRIBO-metingen 4

2.2 Uitgangspunten 5

2.3 Eis slipweerstand 5

3 RESULTATEN ONDERZOEK

3.1 Locatie metingen 6

$\begin{array}{lll}3.2 & \text { Meetresultaten } & 7\end{array}$

3.3 Toetsing aan eis 1

4 CONCLUSIE 


\section{INLEIDING}

Wageningen UR Livestock Research heeft opdracht gegeven aan Aveco de Bondt voor het uitvoeren van stroefheidsmetingen met de TRIBO-meter op roostervloerelementen in 2 vleeskalverstallen; één in Overdinkel en één in Ede. De locatie in Overdinkel betrof een vleeskalverbedrijf met oud rosékalveren. Het bedrijf in Ede was ingericht voor blankvleeskalveren. Beide bedrijven waren deelnemer aan het project "Alternatieve vloeren voor vleeskalveren" waarin de verschillende uitvoeringen van kalvervloeren met elkaar zijn vergeleken. Doel van het onderhavige onderzoek was om op een objectieve wijze vast te stellen hoe de vloeren zich onderling verhouden ten aanzien van stroefheid en beloopbaarheid voor de veeverzorgers en om de resultaten ook te toetsen aan de norm die voor vloeren in openbare ruimtes en arbeidsruimtes van toepassing is. De metingen zijn uitgevoerd op 10 oktober 2016.

De metingen met de TRIBO-meter zijn uitgevoerd en getoetst volgens de norm NEN 7909:2015

"Slipweerstand van beloopbare oppervlakken - Eis en bepalingsmethode". Hierbij is uitgegaan van een gebruikssituatie onder natte omstandigheden omdat dit de situatie in kalverstallen, waar de roosters met urine en mest zijn bevuild, het beste representeert.

Het doel van de TRIBO-metingen is om te bepalen of de stroefheid van de vloerafwerking voldoet aan de voornoemde norm en om de verschillende vloertypen met betrekking tot stroefheid te kunnen classificeren.

Dit rapport bevat een omschrijving van het onderzoek, een weergave van de meetresultaten en de resultaten van de toetsing. De onderzoekswerkzaamheden zijn verricht conform de offerte van Aveco de Bondt, kenmerk 0-MNt/01/161866 d.d. 19 september 2016. 


\section{METHODE VAN ONDERZOEK}

\subsection{MEETMETHODE TRIBO-METINGEN}

Met de TRIBO-meter wordt de slipweerstand van vloeren bepaald volgens ontwerpnorm NEN 7909:2015. In deze norm is de eis opgenomen ten aanzien van de slipweerstand van horizontale en hellende, beloopbare oppervlakken in een openbare ruimte of arbeidsruimte en de daarbij behorende bepalingsmethode.

In de NEN-7909:2015, wordt aangegeven dat de dynamische wrijvingscoëfficiënt moet worden bepaald met de tribometer volgens bijlage D van CEN/TS 16165. Deze bijlage van CEN/TS 16165 beschrijft een procedure waarbij een lichaam met een omschreven massa met daaronder bevestigd drie rubberen sleepvoetjes van omschreven hardheid, vorm en afmetingen, met een vaste snelheid over het te beproeven oppervlak wordt getrokken. Over een lengte van $500 \mathrm{~mm}$ wordt de wrijvingskracht geregistreerd en gemiddeld. Om de dynamische wrijvingscoëfficiënt $\mu$ te bepalen wordt de wrijvingskracht gedeeld door de normaalkracht.

De slipweerstand wordt geclassificeerd met een dynamische wrijvingscoëfficiënt en geeft uitsluitsel over de beloopbaarheid van oppervlakken. De norm is van toepassing op beloopbare oppervlakken die geheel 'in het werk' zijn gemaakt of samengesteld. Het beloopbare oppervlak kan geheel of gedeeltelijk bestaan uit één of meer producten, die elders zijn vervaardigd of ter plaatse zijn geproduceerd. Het oppervlak is al dan niet voorzien van een afwerklaag. Met de in de norm voorgeschreven bepalingsmethode kan te allen tijde na het in gebruik nemen van het beloopbare oppervlak de actuele slipweerstand worden gemeten en beoordeeld. De methode kan op locatie en in het laboratorium worden uitgevoerd. Met deze norm kan niet de duurzaamheid van de slipweerstand van beloopbare oppervlakken worden beoordeeld.

In figuur 1 is de TRIBO-meter op roostervloerelementen op de meetlocatie weergegeven.

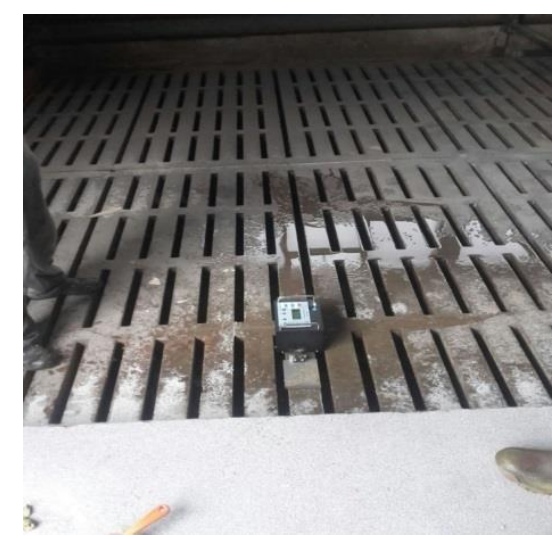

Figuur 1 TRIBO-meter op roostervloerelementen 


\subsection{UITGANGSPUNTEN}

In hoofdstuk 7 van de NEN 7909:2015 is aangegeven op welke wijze de maatgevende dynamische wrijvingscoëfficiënt moet worden bepaald.

De maatgevende dynamische wrijvingscoëfficiënt van een oppervlak is gelijk aan de laagst gemeten waarde van de dynamische wrijvingscoëfficiënt op minimaal drie posities. Voor de betreffende meting zijn verder de volgende randvoorwaarden gehanteerd:

- In verband met de roosterspleten tussen de te meten elementen, zijn de metingen alleen in langsrichting uitgevoerd waardoor de metingen niet in de voorgeschreven 3 richtingen kon worden uitgevoerd;

- Een meetserie op één positie bestaat uit 5 metingen in één richting over hetzelfde spoor;

- De dynamische wrijvingscoëfficiënt wordt, conform voorschrift, per meetserie(=per positie) vastgesteld door de gemiddelde waarde van de $3^{\mathrm{e}} \mathrm{t} / \mathrm{m}$ de $5^{\mathrm{e}}$ meting te bepalen.

\subsection{EIS SLIPWEERSTAND}

In hoofdstuk 5 van de NEN 7909:2015 zijn de eisen weergegeven omtrent de slipweerstand. Voor de betreffende meting op de roostervloerelementen van de vleeskalverstallen in Overdinkel en Ede is conform de NEN 7909:2015 sprake van een natte toepassing.

De slipweerstand moet voor de natte toepassing voldoen aan de in tabel 1 gestelde eisen.

Tabel 1 Eis slipweerstand beloopbaar oppervlak

\begin{tabular}{|l|c|}
\hline Toepassing & Voldoende stroef \\
\hline Natte toepassing & $\mu \geq 0,40$ \\
\hline
\end{tabular}




\section{RESULTATEN ONDERZOEK}

\subsection{LOCATIE METINGEN}

De TRIBO-metingen zijn uitgevoerd op verschillende ondergronden in Overdinkel en Ede. De metingen zijn uitgevoerd op 10 oktober 2016. Onderstaand zijn de onderzochte elementen weergegeven inclusief betreffende ouderdom.

\begin{tabular}{|l|c|l|c|}
\hline \multicolumn{2}{|l|}{ Locatie Overdinkel } & \multicolumn{2}{l|}{ Locatie Ede } \\
\hline Type element & Ouderdom & Type element & Ouderdom \\
\hline ICE (Irish Custom Extruders) & \pm 4 jaar & ICE (Irish Custom Extruders) & \pm 3 jaar \\
\hline Easyfix & \pm 4 jaar & Easyfix & \pm 3 jaar \\
\hline Betonrooster & \pm 10 jaar & Hout & \pm 8 jaar \\
\hline
\end{tabular}




\subsection{MEETRESULTATEN}

De meetresultaten van de TRIBO-metingen zijn in tabel 1 weergegeven. In de kolom "Nr meetserie" staat een "O" voor Overdinkel en de "E" voor Ede. In tabel 1 op de volgende pagina zijn de resultaten weergegeven.

Tabel 1 Resultaten TRIBO-metingen natte condities

\begin{tabular}{|c|c|c|c|c|c|c|c|c|c|}
\hline \multirow{2}{*}{$\begin{array}{c}\mathrm{Nr} \\
\text { meet- } \\
\text { serie }\end{array}$} & \multirow{2}{*}{$\begin{array}{l}\text { Type } \\
\text { element }\end{array}$} & \multirow[t]{2}{*}{ Meetrichting } & \multirow{2}{*}{$\begin{array}{l}\text { Lucht- } \\
\text { temp. } \\
{ }^{\circ} \mathrm{C}\end{array}$} & \multicolumn{5}{|c|}{ Meting slipweerstand $[\mu]$} & \multirow{2}{*}{$\begin{array}{l}\text { Dynamische } \\
\text { wrijvings- } \\
\text { coëfficient } \\
\text { (Gemiddelde van } \\
\text { meting } 3 \mathrm{t} / \mathrm{m} \mathrm{5} \text { ) }\end{array}$} \\
\hline & & & & 1 & 2 & 3 & 4 & 5 & \\
\hline $1(0)$ & ICE & Langsrichting & 20 & 0,49 & 0,46 & 0,41 & 0,43 & 0,40 & 0,41 \\
\hline $2(0)$ & ICE & Langsrichting & 20 & 0,45 & 0,46 & 0,49 & 0,47 & 0,49 & 0,48 \\
\hline $3(0)$ & ICE & Langsrichting & 20 & 0,45 & 0,49 & 0,48 & 0,49 & 0,50 & 0,49 \\
\hline $6(0)$ & Easyfix & Langsrichting & 20 & 0,35 & 0,32 & 0,34 & 0,33 & 0,32 & 0,33 \\
\hline $7(0)$ & Easyfix & Langsrichting & 20 & 0,33 & 0,33 & 0,31 & 0,34 & 0,35 & 0,33 \\
\hline $8(0)$ & Easyfix & Langsrichting & 20 & 0,42 & 0,41 & 0,40 & 0,39 & 0,38 & 0,39 \\
\hline $9(0)$ & Betonrooster & Langsrichting & 12 & 0,46 & 0,50 & 0,52 & 0,50 & 0,53 & 0,52 \\
\hline $10(0)$ & Betonrooster & Langsrichting & 12 & 0,42 & 0,44 & 0,47 & 0,50 & 0,49 & 0,49 \\
\hline $11(0)$ & Betonrooster & Langsrichting & 12 & 0,44 & 0,46 & 0,47 & 0,48 & 0,40 & 0,45 \\
\hline $1(\mathrm{E})$ & Easyfix & Langsrichting & 14 & 0,53 & 0,51 & 0,53 & 0,52 & 0,51 & 0,52 \\
\hline $3(E)$ & Easyfix & Langsrichting & 14 & 0,53 & 0,48 & 0,59 & 0,57 & 0,59 & 0,58 \\
\hline $5(E)$ & Easyfix & Langsrichting & 14 & 0,56 & 0,59 & 0,55 & 0,58 & 0,60 & 0,58 \\
\hline $6(E)$ & Hout & Langsrichting & 14 & 0,64 & 0,64 & 0,62 & 0,68 & 0,68 & 0,66 * \\
\hline $7(\mathrm{E})$ & Hout & Langsrichting & 14 & 0,28 & 0,32 & 0,27 & 0,30 & 0,33 & $0,30^{* *}$ \\
\hline $8(\mathrm{E})$ & Hout & Langsrichting & 14 & 0,30 & 0,28 & 0,30 & 0,26 & 0,27 & 0,28 ** \\
\hline $12(\mathrm{E})$ & ICE & Langsrichting & 14 & 0,71 & 0,71 & 0,69 & 0,69 & 0,69 & 0,69 \\
\hline $13(E)$ & ICE & Langsrichting & 14 & 0,68 & 0,63 & 0,67 & 0,56 & 0,61 & 0,61 \\
\hline $14(\mathrm{E})$ & ICE & Langsrichting & 14 & 0,62 & 0,58 & 0,56 & 0,56 & 0,51 & 0,54 \\
\hline $15(E)$ & ICE & Langsrichting & 14 & 0,58 & 0,60 & 0,54 & 0,54 & 0,54 & 0,54 \\
\hline $16(E)$ & ICE & Langsrichting & 14 & 0,61 & 0,56 & 0,58 & 0,73 & 0,64 & 0,65 \\
\hline $17(\mathrm{E})$ & ICE & Langsrichting & 14 & 0,61 & 0,58 & 0,57 & 0,76 & 0,83 & 0,72 \\
\hline
\end{tabular}

* Met nerf mee gemeten onder droge condities

** Met nerf mee gemeten onder natte condities

Ten aanzien van de metingen op hout is één meting onder droge condities uitgevoerd en twee metingen onder natte condities. Op aanwijzing van de opdrachtgever is hier geen derde meting onder natte condities uitgevoerd.

Op de elementen "ICE" in Ede bleek tijdens de uitvoering van de meting, dat het apparaat zich schokkend voortbewoog over de elementen. Door de grote mate van indrukbaarheid van het materiaal, bleek er een zogenaamd stick-slip effect op te treden, waarbij het meetvoetje tijdens 
de meting, vast lijkt te zitten aan het element, vervolgens los schiet en daarna opnieuw weer vast lijkt te zitten. Om deze redenen zijn hier extra metingen uitgevoerd. De gemiddelde wrijvingscoëfficiënt op ICE in Ede kon door dit effect minder nauwkeurig worden vastgesteld. Doordat tijdens dit stick-slip effect de wrijvingscoëfficiënt op dit element steeds de maximale wrijvingscoëfficiënt van 1,00 bereikt (zie Figuur 1) kan de werkelijke stroefheidswaarde mogelijk nog hoger uitvallen. De lage pieken in dit signaal worden veroorzaakt doordat tijdens het "los schieten" van het voetje ook de wrijvingscoëfficiënt wordt gemeten.

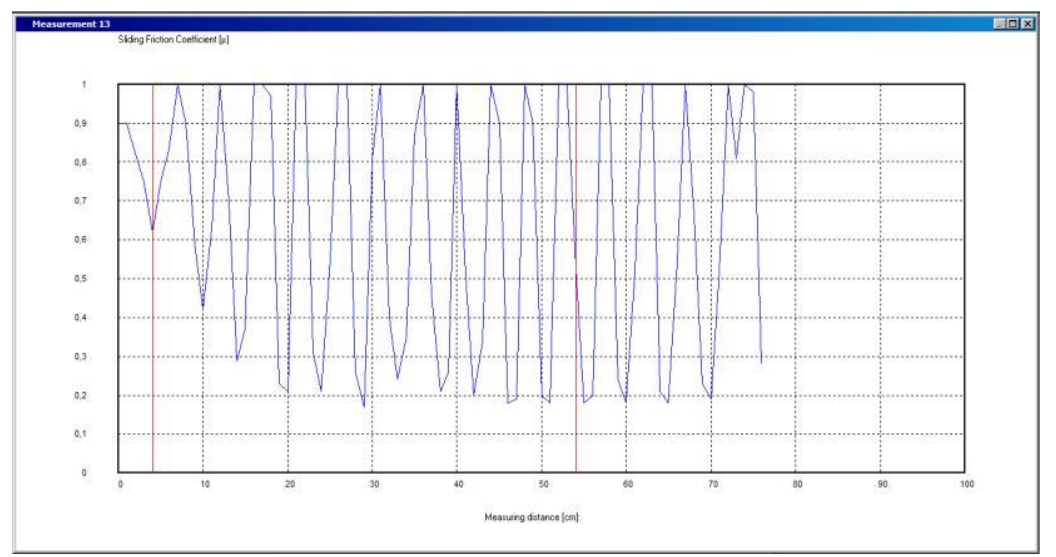

Figuur 1 Voorbeeld meetsignaal bij optreden stick-slip effect

\subsection{TOETSING AAN EIS}

De resultaten van de TRIBO-metingen zijn getoetst aan de eis zoals aangegeven in hoofdstuk 5 van de NEN 7909:2015. Hierin geldt dat de maatgevende dynamische wrijvingscoëfficiënt van een oppervlak gelijk is aan de laagst gemeten dynamische wrijvingscoëfficiënt op minimaal drie posities. De toetsing is hierbij per meetlocatie uitgevoerd. De resultaten van de toetsing zijn op de volgende pagina in tabel 2 weergegeven.

Tabel 2 Toetsing TRIBO-metingen aan eis (natte condities)

\begin{tabular}{|c|c|l|c|c|c|}
\hline Meetserie & $\begin{array}{c}\text { Type } \\
\text { element }\end{array}$ & $\begin{array}{l}\text { Maatgevende } \\
\text { richting }\end{array}$ & $\begin{array}{c}\text { Maatgevende } \\
\text { dynamische } \\
\text { wrijvingscoëfficiën } \\
\mathbf{t} \\
{[\mu]}\end{array}$ & $\begin{array}{c}\text { Voldoende } \\
\text { stroef volgens } \\
\text { eis } \\
\text { Natte } \\
\text { toepassing }\end{array}$ & $\begin{array}{c}\text { Voldoet } \\
\text { aan eis } \\
\text { JA/NEE }\end{array}$ \\
\hline $1,2,3(0)$ & ICE & Langsrichting & 0,41 & $\mu \geq 0,40$ & JA \\
\hline $6,7,8(0)$ & Easyfix & Langsrichting & 0,33 & $\mu \geq 0,40$ & NEE \\
\hline $9,10,11(0)$ & Betonrooster & Langsrichting & 0,45 & $\mu \geq 0,40$ & JA \\
\hline $1,3,5(E)$ & Easyfix & Langsrichting & 0,52 & $\mu \geq 0,40$ & JA \\
\hline 7 en $8(E)$ & Hout & Langsrichting & 0,28 & $\mu \geq 0,40$ & NEE \\
\hline $12 \mathrm{t} / \mathrm{m} 17(\mathrm{E})$ & ICE & Langsrichting & 0,54 & $\mu \geq 0,40$ & $\mathrm{JA}$ \\
\hline
\end{tabular}




\section{CONCLUSIE}

Op basis van de uitgevoerde TRIBO-metingen op roostervloerelementen in de vleeskalverstallen in Overdinkel en Ede zijn per type element de maatgevende dynamische wrijvingscoëfficiënten weergegeven in Tabel 2.

Tabel 2 Overzicht maatgevende resultaten van onderzochte elementen

\begin{tabular}{|c|c|c|}
\hline \multirow{2}{*}{ Type element } & \multicolumn{2}{|c|}{ Maatgevende dynamische wrijvingscoëfficiënt } \\
& \multicolumn{2}{|c|}{$\boldsymbol{\mu}]$} \\
\cline { 2 - 3 } & Overdinkel & Ede \\
\hline ICE & 0,41 & 0,54 \\
\hline Easyfix & 0,33 & 0,52 \\
\hline Betonrooster & 0,45 & - \\
\hline Hout & - & 0,28 \\
\hline
\end{tabular}

Op basis van deze resultaten kan worden geconcludeerd dat "Hout" de laagste wrijvingscoëfficiënt heeft gevolgd door het Easyfix element in Overdinkel. Deze elementen voldoen ook niet aan de eisen die in NEN 7909:2015 worden gesteld aan de minimaal benodigde stroefheid voor voetgangers in openbare ruimten (eis $\geq 0,40$ ).

De ICE-verharding in Overdinkel voldoet nog net wel aan deze norm. Het betonrooster voldoet met een waarde van 0,45 ook aan deze norm, maar de hoogste wrijvingscoëfficiënten worden gemeten op Easyfix $(0,52)$ en ICE $(0,54)$ in Ede.

In hoeverre de gestelde eisen ook representatief zijn voor de kalveren in de betreffende stallen heeft mede te maken met de verticale druk ${ }^{1}$ die de kalveren door hun gewicht op de elementen uitoefenen. In Overdinkel hebben de rosekalveren een geschat gewicht variërend van $100-360 \mathrm{~kg}$, waardoor de verticale druk zal variëren tussen 10 en $18 \mathrm{~N} / \mathrm{cm}^{2}$. Het gewicht van de blankveekalveren in Ede zal naar schatting variëren tussen de 50 en $250 \mathrm{~kg}$, waardoor de verticale druk zal variëren tussen de 5 en $12,5 \mathrm{~cm}^{2}$. De TRIBO-meter voert de metingen uit bij een verticale druk van circa $9 \mathrm{~N} / \mathrm{cm}^{2}$. Deze verticale druk zit in ieder geval in dezelfde range als waarmee de kalveren druk uitvoeren op de vloerelementen.

1 Voor het berekenen van de verticate druk er van uitgegaan dat elke poot van een jong dier een oppervlakte heeft van circa $25 \mathrm{~cm}^{2}$ en oudere dieren circa $50 \mathrm{~cm}^{2}$. 


\section{Bijlage 11 Resultaten demoafdelingen}

Bevuiling kalveren

\begin{tabular}{|l|c|c|c|}
\cline { 2 - 4 } \multicolumn{1}{c|}{} & \multicolumn{3}{c|}{ Gemiddeld percentage bevuilde buik } \\
\cline { 2 - 4 } \multicolumn{1}{c|}{} & In babybox & $8-10$ weken na opstart & 2 weken voor slacht \\
\hline Referentie & 0 & 0.7 & 1 \\
\hline ICE met flappen & 0.5 & 10.8 & 17.7 \\
\hline Easyfix Vaars & 0 & 0 & 24.5 \\
\hline ICE Vaars & 0 & 3 & 15.2 \\
\hline
\end{tabular}

\begin{tabular}{|l|c|c|c|}
\cline { 2 - 4 } \multicolumn{1}{c|}{} & \multicolumn{3}{c|}{ Gemiddelde bevuilingsscore } \\
\cline { 2 - 4 } \multicolumn{1}{c|}{} & In babybox & $8-10$ weken na opstart & 2 weken voor slacht \\
\hline Referentie & 3 & 2.8 & 6 \\
\hline ICE met flappen & 4.7 & 17.4 & 28 \\
\hline Easyfix Vaars & 18.4 & 15 & 37.9 \\
\hline ICE Vaars & 22.9 & 23.2 & 31.3 \\
\hline
\end{tabular}

Vloeren

\begin{tabular}{|l|c|c|}
\cline { 2 - 3 } \multicolumn{1}{c|}{} & \multicolumn{2}{c|}{ Gemiddeld percentage van de vloer nat } \\
\cline { 2 - 3 } \multicolumn{1}{c|}{} & $8-10$ weken na opstart & 2 weken voor slacht \\
\hline Easyfix Vaars & 41.9 & 32.5 \\
\hline ICE Vaars & 51.3 & 27.5 \\
\hline
\end{tabular}

\begin{tabular}{|l|c|c|}
\cline { 2 - 3 } \multicolumn{1}{c|}{} & \multicolumn{2}{c|}{ Gemiddeld percentage van de vloer volgelopen met mest } \\
\cline { 2 - 3 } \multicolumn{1}{c|}{} & $8-10$ weken na opstart & 2 weken voor slacht \\
\hline ICE met flappen & 35.2 & 58 \\
\hline
\end{tabular}




\section{Bijlage 12 Vragenlijst enquête beloopbaarheid en levensduur}

\section{Blankvleeskalveren}

Korte aanvullende enquete deelnemers project alternatieve vloeren voor vleeskalveren

We vragen $\mathrm{u}$ alle vragen te beantwoorden door aan te kruisen wat $\mathrm{u}$ van toepassing vindt.

Vragen:

1 Met welke categorie vleeskalveren heeft u deelgenomen aan het onderzoek

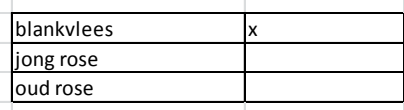

jong rose

2 Wat was de referentievloer op uw bedrijf

Hardhouten rooster

Betonnen rooster

3 Hoe ervaart u de beloopbaarheid van de verschillende kalvervloeren voor de kalveren

\begin{tabular}{|c|c|c|c|c|c|c|}
\hline & slecht & matig & voldoende & ruim voldoende & goed & uitstekend \\
\hline Referentievloer & & & & & $x x x x x$ & \\
\hline Groene Vlag / ICE & $\mathrm{x}$ & & $\mathrm{x}$ & $x$ & $x$ & $x$ \\
\hline Easyfix / van Beek & & & & $x x x$ & $x x$ & \\
\hline
\end{tabular}

totaal-score gem score Omschrijuing waardering

$25 \quad 5.0$ goed

$19-3.8$ voldoende tot ruim voldoende

Easyfix/van Beek

$\mathrm{xxx}$

4.4 ruim voldoende tot goed

4 Hoe ervaart u de beloopbaarheid van de verschillende vloeren voor uzelf

\begin{tabular}{|c|c|c|c|c|c|c|}
\hline & slecht & matig & voldoende & ruim voldoende & goed & uitstekend \\
\hline Referentievloer & & & & $\mathrm{x}$ & $x x x$ & $x$ \\
\hline Groene Vlag / ICE & $\mathrm{x}$ & $x$ & $x$ & $x$ & $x$ & \\
\hline Easyfix / van Beek & & & $x x$ & $\mathrm{xx}$ & $x$ & \\
\hline
\end{tabular}

\section{$25 \quad 5.0$ goed}

$15 \quad 3.0$ voldoende

Easyfix/van Beek

$\mathrm{xx}$

3.8 ruim voldoende

5 Hoe ervaart u de grip / stroefheid van de vloeren als u er overheen loopt

\begin{tabular}{|l|l|l|l|l|l|l|}
\hline & \multicolumn{1}{|c|}{ slecht } & \multicolumn{1}{c|}{ matig } & voldoende & ruim voldoende & \multicolumn{1}{c|}{ goed } & \multicolumn{1}{c|}{ uitstekend } \\
\hline Referentievloer & & & & $\mathrm{XXX}$ & $\mathrm{XX}$ & \\
\hline Groene Vlag / ICE & $\mathrm{XX}$ & $\mathrm{X}$ & $\mathrm{X}$ & & $\mathrm{X}$ & \\
\hline Easyfix/van Beek & & $\mathrm{X}$ & $\mathrm{XX}$ & & $\mathrm{XX}$ & \\
\hline
\end{tabular}

6 Hoe ervaart u de veiligheid als $\mathrm{u}$ in een hok met zware kalveren over de vloer loopt?

\begin{tabular}{|l|l|l|l|l|l|l|}
\hline & slecht & \multicolumn{1}{|c|}{ matig } & voldoende & ruim voldoende & \multicolumn{1}{c|}{ goed } & uitstekend \\
\hline Referentievloer & & & $\mathrm{X}$ & $\mathrm{XX}$ & $\mathrm{XX}$ \\
\hline Groene Vlag / ICE & $\mathrm{XX}$ & $\mathrm{X}$ & $\mathrm{X}$ & & $\mathrm{X}$ & \\
\hline Easyfix / van Beek & & $\mathrm{XX}$ & $\mathrm{X}$ & $\mathrm{XX}$ & $\mathrm{X}$ & \\
\hline
\end{tabular}

$12 \quad 2.4$ matig tot voldoend

Easyfix/van Beck

$\mathrm{xx}$

2.4 matig tot voldoe
4.0 ruim voldoende

7 Hoe lang heeft u de verschillende vloeren in gebruik?

\begin{tabular}{|c|c|c|c|c|c|c|}
\hline & 2 jaar & 3 jaar & 4 jaar & 5 jaar & $6-10$ jaar & meer dan 11 jaar \\
\hline Referentievloer & & & $x$ & & & $x x x x$ \\
\hline Groene V $\mathrm{I}_{\mathrm{C}}$ & & $x$ & $x x x$ & $x$ & & \\
\hline Easyfix / van Beek & & $x$ & $x x x$ & $x$ & & \\
\hline
\end{tabular}


8 Is de stroefheid van de vloeren naar uw idee in de loop van het gebruik veranderd ?

\begin{tabular}{|l|l|l|l|l|l|}
\hline & ja, veel stroever & $\begin{array}{l}\text { ja, beetje } \\
\text { stroever gewor- } \\
\text { gewor-den } \\
\text { den }\end{array}$ & $\begin{array}{l}\text { nee is niet ver- } \\
\text { anderd }\end{array}$ & $\begin{array}{l}\text { ja, beetje gladder } \\
\text { geworden }\end{array}$ & $\begin{array}{l}\text { ja, veel gladder } \\
\text { geworden }\end{array}$ \\
\hline Referentievloer & & $\mathrm{X}$ & $\mathrm{XXX}$ & $\mathrm{X}$ & \\
\hline Groene Vlag/ICE & & $\mathrm{X}$ & $\mathrm{XX}$ & $\mathrm{XX}$ & \\
\hline Easyfix/van Beek & & $\mathrm{X}$ & $\mathrm{XXXX}$ & & \\
\hline
\end{tabular}

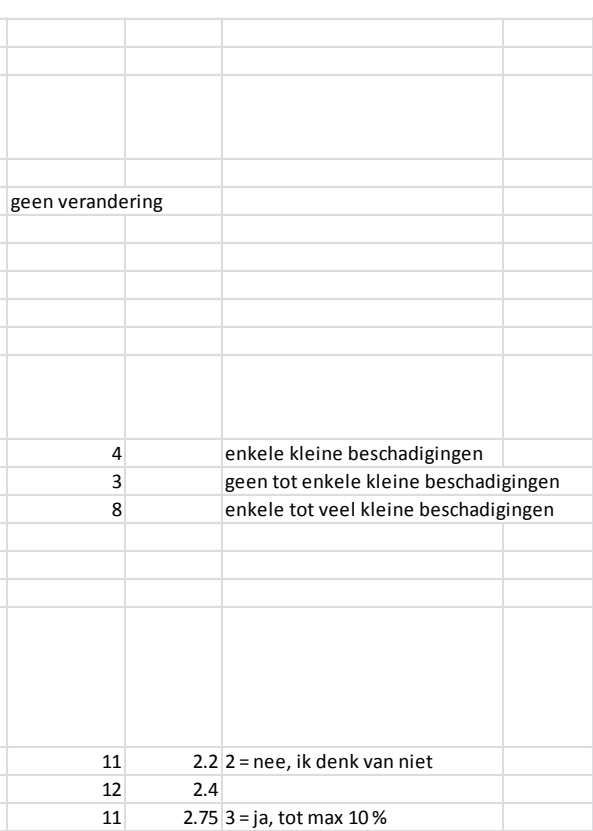

11 Op hoeveel jaar schat u de technische levensduur van de vloeren in?

\begin{tabular}{|c|c|c|c|c|c|c|}
\hline & tot 5 jaar & 6 tot 8 jaar & 9-12 jaar & 13-17 jaar & $18-25$ jaar & langer \\
\hline Referentievloer & & & $x$ & $x x x$ & $x$ & \\
\hline Groene Vlag / ICE & & & $\mathrm{XXXX}$ & & $x$ & \\
\hline Easyfix / van Beek & & $x \mathrm{XX}$ & $x$ & $\mathrm{x}$ & & \\
\hline
\end{tabular}

gemiddeld
\begin{tabular}{|l|l|}
75 & 15 jaar \\
\hline 60 & 12 jaar \\
\hline 46 & 9.2 jaar \\
\hline
\end{tabular}

12 Op hoeveel jaar schat u de economische levensduur in / welke afschrijvingstermijn zou u hanteren?

\begin{tabular}{|c|c|c|c|c|c|c|}
\hline & 5 jaar & 7 jaar & 10 jar & 15 jaar & $20 \mathrm{jaar}$ & langer \\
\hline Referentievloer & & & $x x x x$ & $x$ & & \\
\hline Groene Vlag / ICE & & $x$ & $\mathrm{xxx}$ & & $x$ & \\
\hline Easyfix / van Beek & & $\begin{array}{c}x \\
\end{array}$ & $x x x$ & $x$ & & \\
\hline
\end{tabular}

13 Bent $u$ tevreden over de wijze waarop de vloeren zich houden

\begin{tabular}{|l|l|l|l|l|l|}
\hline & $\begin{array}{l}\text { ja, ik ben daar } \\
\text { zeer tevreden } \\
\text { over }\end{array}$ & $\begin{array}{l}\text { Ja, ik ben daar } \\
\text { tevreden over }\end{array}$ & $\begin{array}{l}\text { Ik ben dar niet } \\
\text { tevreden of } \\
\text { ontevre-den over }\end{array}$ & $\begin{array}{l}\text { Nee, ik ben daar } \\
\text { onteveden over }\end{array}$ & $\begin{array}{l}\text { Nee, ik ben daar } \\
\text { zeer ontevreden } \\
\text { over }\end{array}$ \\
\hline Referentievloer & $\mathrm{XXX}$ & $\mathrm{XX}$ & & \\
\hline Groene Vlag/ICE & & $\mathrm{XXXX}$ & $\mathrm{X}$ & & \\
\hline Easyfix/van Beek & & $\mathrm{XXX}$ & $\mathrm{XX}$ & \\
\hline
\end{tabular}

3.6 neutraal tot tevreden 


\section{Rosé kalveren}

Korte aanvullende enquete deelnemers project alternatieve vloeren voor vleeskalveren

We vragen $\mathrm{u}$ alle vragen te beantwoorden door aan te kruisen wat $\mathrm{u}$ van toepassing vindt. Vragen:

1 Met welke categorie vleeskalveren heeft u deelgenomen aan het onderzoek

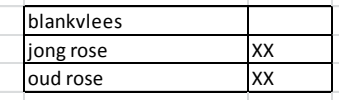

2 Wat was de referentievloer op uw bedrijf

\begin{tabular}{|l|l|}
\hline Hardhouten rooster & \\
\hline Betonnen rooster & $\mathrm{XxXX}$ \\
\hline
\end{tabular}

3 Hoe ervaart u de beloopbaarheid van de verschillende kalvervloeren voor de kalveren

\begin{tabular}{|l|l|l|l|l|l|l|}
\hline & slecht & matig & voldoende & $\begin{array}{l}\text { ruim } \\
\text { voldoende }\end{array}$ & goed & uitstekend \\
\hline Referentievloer & & $\mathrm{X}$ & $\mathrm{X}$ & $\mathrm{X}$ & $\mathrm{X}$ & \\
\hline Groene Vlag/ICE & $\mathrm{XX}$ & $\mathrm{X}$ & $\mathrm{X}$ & $\mathrm{X}$ & \\
\hline Easyfix / van Beek & & $\mathrm{X}$ & $\mathrm{X}$ & $\mathrm{X}$ & $\mathrm{X}$ & \\
\hline
\end{tabular}

weet ik

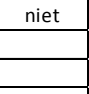

totaal- gem Omschrijving

waardering

4 Hoe ervaart u de beloopbaarheid van de verschillende vloeren voor uzelf

\begin{tabular}{|l|l|l|l|l|l|l|}
\hline & slecht & matig & voldoende & $\begin{array}{l}\text { ruim } \\
\text { voldoende }\end{array}$ & goed & uitstekend \\
\hline
\end{tabular}

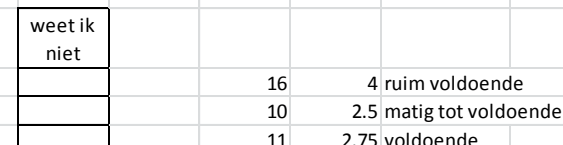

3.5 voldoende tot ruim voldoend

$13 \quad 3.25$ voldoende

tot ruim voldoende

5 Hoe ervaart u de grip / stroefheid van de vloeren als u er overheen loopt

\begin{tabular}{|l|l|l|l|l|l|l|}
\hline & slecht & matig & voldoende & $\begin{array}{l}\text { ruim } \\
\text { voldoende }\end{array}$ & goed & uitstekend \\
\hline Referentievloer & & & $\mathrm{X}$ & $\mathrm{X}$ & $\mathrm{XX}$ & \\
\hline Groene Vlag/ICE & $\mathrm{X}$ & $\mathrm{XX}$ & $\mathrm{X}$ & & & \\
\hline Easyfix / van Beek & & $\mathrm{XXX}$ & & $\mathrm{X}$ & & \\
\hline
\end{tabular}

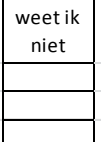

$17 \quad 4.25$ ruim voldoende

Easyfix / van Beek

\begin{tabular}{|r|r|c|}
\hline & 17 & 4.25 ruim voldoende \\
\hline & 8 & 2 matig \\
\hline & 10 & 2.5 matig tot voldoende \\
\hline
\end{tabular}

6 Hoe ervaart u de veiligheid als $\mathrm{u}$ in een hok met zware kalveren over de vloer loopt?

\begin{tabular}{|l|l|l|l|l|l|l|}
\hline & slecht & matig & $\begin{array}{l}\text { voldoend } \\
\text { e }\end{array}$ & $\begin{array}{c}\text { ruim } \\
\text { voldoende }\end{array}$ & goed & $\begin{array}{c}\text { uitsteken } \\
\mathrm{d}\end{array}$ \\
\hline Referentievloer & & & $\mathrm{X}$ & $\mathrm{XXX}$ & & \\
\hline Groene Vlag/ICE & $\mathrm{XX}$ & $\mathrm{X}$ & $\mathrm{X}$ & & & \\
\hline Easyfix / van Beek & & $\mathrm{XX}$ & $\mathrm{XX}$ & & & \\
\hline
\end{tabular}

7 Hoe lang heeft $\mathrm{u}$ de verschillende vloeren in gebruik?

\begin{tabular}{|l|l|l|l|l|l|l|}
\hline & 2 jaar & 3 jaar & 4 jaar & 5 jaar & 6 - 10 jaar & $\begin{array}{c}\text { meer dan } \\
11 \text { jaar }\end{array}$ \\
\hline Referentievloer & & & & $\mathrm{X}$ & & $\mathrm{XXX}$ \\
\hline Groene Vlag / ICE & & $\mathrm{XXX}$ & $\mathrm{X}$ & & & \\
\hline Easyfix / van Beek & & $\mathrm{XXX}$ & $\mathrm{X}$ & & & \\
\hline
\end{tabular}


8 Is de stroefheid van de vloeren naar uw idee in de loop van het gebruik veranderd?

\begin{tabular}{|l|l|l|l|l|l|}
\hline & $\begin{array}{l}\text { ja, veel stroever } \\
\text { gewor-den }\end{array}$ & $\begin{array}{l}\text { ja, beetje } \\
\text { stroever gewor- } \\
\text { den }\end{array}$ & $\begin{array}{l}\text { nee is niet ver- } \\
\text { anderd }\end{array}$ & $\begin{array}{l}\text { ja, beetje gladder } \\
\text { geworden }\end{array}$ & $\begin{array}{l}\text { ja, veel gladder } \\
\text { geworden }\end{array}$ \\
\hline Referentievloer & & $\mathrm{X}$ & $\mathrm{XXX}$ & $\mathrm{X}$ & \\
\hline Groene Vlag/ICE & & $\mathrm{X}$ & $\mathrm{XX}$ & $\mathrm{XX}$ & \\
\hline Easyfix / van Beek & & $\mathrm{X}$ & $\mathrm{XXXX}$ & & \\
\hline
\end{tabular}

\section{geen verandering}

9 Ziet u beschadigingen aan de vloer ontstaan

\begin{tabular}{|l|l|l|l|l|l|}
\hline & $\begin{array}{l}\text { nee, de vloer is } \\
\text { nog } \\
\text { onbeschadigd }\end{array}$ & $\begin{array}{l}\text { nee, ik heb de } \\
\text { indruk van niet }\end{array}$ & $\begin{array}{l}\text { Ja, ik zie enkele } \\
\text { kleine } \\
\text { beschadigingen }\end{array}$ & $\begin{array}{l}\text { Ja, ik zie veel kleine } \\
\text { beschadigingen }\end{array}$ & $\begin{array}{l}\text { Ja, ik zie grote } \\
\text { beschadigingen }\end{array}$ \\
\hline Referentievloer & & $X$ & $\mathrm{XXXX}$ & & \\
\hline Groene Vlag / ICE & & $\mathrm{XX}$ & $\mathrm{XXX}$ & & \\
\hline Easyfix / van Beek & & & $\mathrm{XX}$ & $\mathrm{XXX}$ & \\
\hline
\end{tabular}

10 Verwacht $\mathrm{u}$ dat $\mathrm{u}$ binnen 5 jaar delen van de vloer zult moeten vervangen?

\begin{tabular}{|c|c|c|c|c|c|}
\hline & $\begin{array}{l}\text { nee, ik ben er } \\
\text { van overtuigd } \\
\text { van niet }\end{array}$ & $\begin{array}{l}\text { Nee, ik denk van } \\
\text { niet }\end{array}$ & $\begin{array}{l}\text { Ja, ik verwacht } \\
\text { tot maximaal } 10 \\
\% \text { te moeten } \\
\text { vervangen }\end{array}$ & $\begin{array}{l}\text { Ja, ik verwacht tot } \\
\text { maximaal } 25 \% \text { te } \\
\text { moeten vervangen }\end{array}$ & \begin{tabular}{|l|} 
Ja, ik verwacht dat \\
de vloer dan bijna \\
of helemaal \\
vervangen moet \\
worden
\end{tabular} \\
\hline Referentievloer & $x$ & $x x$ & $x x$ & & \\
\hline Groene Vlag / ICE & & $\mathrm{xxx}$ & $x x$ & & \\
\hline Easyfix / van Beek & & $x$ & $\mathrm{xxx}$ & & \\
\hline
\end{tabular}

11 Op hoeveel jaar schat $u$ de technische levensduur van de vloeren in?

\begin{tabular}{|c|c|c|c|c|c|c|}
\hline & tot 5 jaar & 6 tot 8 jaar & 9-12 jaar & 13-17 jaar & $18-25$ jaar & langer \\
\hline Referentievloer & & & $x$ & $\mathrm{xxx}$ & $\mathrm{x}$ & \\
\hline Groene Vlag / ICE & & & $x x x x$ & & $x$ & \\
\hline Easyfix / van Beek & & $x x$ & $x$ & $x$ & & \\
\hline
\end{tabular}

$112.22=$ nee, ik denkvan niet 2.4

$2.753=$ ja, tot $\max 10 \%$

$$
\begin{array}{|l|l|}
\hline \multicolumn{2}{|c|}{\text { gemiddeld }} \\
\hline 75 & 15 \text { jaar } \\
\hline 60 & 12 \text { jaar } \\
\hline 46 & 9.2 \text { jaar } \\
\hline
\end{array}
$$

\begin{tabular}{|c|c|c|c|c|c|c|}
\hline & 5 jaar & 7 jaar & 10 jaar & 15 jaar & 20 jaar & langer \\
\hline Referentievloer & & & $x x x x$ & $x$ & & \\
\hline Groene Vlag / ICE & & $\mathrm{x}$ & $\mathrm{xxx}$ & & $x$ & \\
\hline Easyfix / van Beek & & $x$ & $x x x$ & $x$ & & \\
\hline
\end{tabular}

12 Op hoeveel jaar schat u de economische levensduur in / welke afschrijvingstermijn zou u hanteren?

13 Bent u teureden over de wijze waarop de vloeren zich houden

\begin{tabular}{|l|l|l|l|l|l|}
\hline & $\begin{array}{l}\text { ja, ik ben daar } \\
\text { zeer tevreden } \\
\text { over }\end{array}$ & $\begin{array}{l}\text { Ja, ik ben daar } \\
\text { tevreden over }\end{array}$ & $\begin{array}{l}\text { Ik ben daar niet } \\
\text { tevreden of } \\
\text { ontevre-den over }\end{array}$ & $\begin{array}{l}\text { Nee, } i \mathrm{ik} \text { ben daar } \\
\text { ontereden over }\end{array}$ & $\begin{array}{l}\text { Nee, ik ben daar } \\
\text { zeer ontevreden } \\
\text { over }\end{array}$ \\
\hline Referentievloer & $\mathrm{XXX}$ & $\mathrm{XX}$ & & \\
\hline Groene Vlag/ICE & & $\mathrm{XXXX}$ & $\mathrm{X}$ & & \\
\hline Easyfix / van Beek & & $\mathrm{XXX}$ & $\mathrm{XX}$ & & \\
\hline
\end{tabular}

nkele kleine beschadigingen

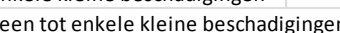
the to veel kleine beschadigingen 


\section{Bijlage 13 Afschrijvingsscenario's gebruikers en leveranciers}

Tabel 1. Meerkosten van zachte vloeren ten opzichte van een betonvloer (gebruiker).

\begin{tabular}{|c|c|c|c|c|c|c|c|}
\hline \multirow[b]{3}{*}{ Totaal investering } & \multirow{3}{*}{$\begin{array}{l}\text { Referentie } \\
\text { Blankvlees } \\
\text { (C/dpl) }\end{array}$} & \multicolumn{3}{|c|}{ Nieuwbouw } & \multicolumn{3}{|c|}{ Renovatie } \\
\hline & & ICE & \multicolumn{2}{|c|}{ ICE kleppen Easyfix } & \multicolumn{2}{|l|}{ ICE } & \multirow{2}{*}{$\begin{array}{r}\text { Easyfix } \\
208\end{array}$} \\
\hline & & 184 & 276 & 108 & & 284 & \\
\hline \multicolumn{8}{|l|}{ Jaarkosten } \\
\hline - Afschrijving & & 26,3 & 44,6 & 15,4 & & 36,3 & 25,4 \\
\hline - Onderhoud & & 3,7 & 3,7 & 4,3 & & 5,5 & 7,9 \\
\hline - Rente & & 2,8 & 4,1 & 1,6 & & 4,1 & 3,0 \\
\hline \multirow{3}{*}{$\begin{array}{l}\text { Totaal jaarkosten } \\
\text { C per kg }\end{array}$} & $(C / d p l)$ & 33 & 52 & 21 & & 46 & 36 \\
\hline & & C 0,13 & C 0,21 & C 0,08 & $\boldsymbol{c}$ & 0,18 & C 0,14 \\
\hline & Rosé & ICE & ICE kleppe & asyfix & ICE & & Easyfix \\
\hline Totaal investering & $(\epsilon / \mathrm{dpl})$ & 222 & 314 & 131 & & 229 & 131 \\
\hline \multicolumn{8}{|l|}{ Jaarkosten } \\
\hline - Afschrijving & & 31,7 & 50,1 & 18,7 & & 32,7 & 18,7 \\
\hline - Onderhoud & & 4,4 & 6,3 & 5,2 & & 4,6 & 5,2 \\
\hline - Rente & & 3,3 & 4,7 & 2,0 & & 3,4 & 2,0 \\
\hline Totaal jaarkosten & $(\epsilon / \mathrm{dpl})$ & 39 & 61 & 26 & & 41 & 26 \\
\hline $\boldsymbol{\epsilon}$ per kg & & C 0,12 & C 0,18 & C 0,08 & $\boldsymbol{c}$ & 0,12 & C 0,08 \\
\hline
\end{tabular}


Tabel 2. Meerkosten van zachte vloeren ten opzichte van een betonvloer (leverancier).

\begin{tabular}{|c|c|c|c|c|c|c|c|}
\hline \multirow[b]{3}{*}{ Totaal investering } & \multirow{3}{*}{$\begin{array}{l}\text { Referentie } \\
\text { Blankvlees } \\
\text { (C/dpl) }\end{array}$} & \multicolumn{3}{|c|}{ Nieuwbouw } & \multicolumn{3}{|c|}{ Renovatie } \\
\hline & & ICE & \multicolumn{2}{|c|}{ ICE kleppen Easyfix } & \multicolumn{2}{|l|}{ ICE } & \multirow{2}{*}{$\begin{array}{r}\text { Easyfix } \\
208\end{array}$} \\
\hline & & 184 & 276 & 108 & & 284 & \\
\hline \multicolumn{8}{|l|}{ Jaarkosten } \\
\hline - Afschrijving & & 9,2 & 27,5 & 5,4 & & 14,2 & 10,4 \\
\hline - Onderhoud & & 3,7 & 3,7 & 2,2 & & 5,5 & 4,0 \\
\hline - Rente & & 2,8 & 4,1 & 1,6 & & 4,3 & 3,1 \\
\hline Totaal jaarkosten & $(c / d p l)$ & 16 & 35 & 9 & & 24 & 17 \\
\hline \multirow[t]{2}{*}{$\boldsymbol{C}$ per kg } & & c 0,06 & C 0,14 & C 0,04 & $\boldsymbol{c}$ & 0,09 & C 0,07 \\
\hline & Rosé & ICE & \multicolumn{2}{|c|}{ ICE kleppen Easyfix } & \multicolumn{2}{|l|}{ ICE } & Easyfix \\
\hline Totaal investering & $(C / d p l)$ & 222 & 314 & 131 & & 229 & 131 \\
\hline \multicolumn{8}{|l|}{ Jaarkosten } \\
\hline - Afschrijving & & 11,1 & 29,5 & 6,5 & & 11,4 & 6,5 \\
\hline - Onderhoud & & 4,4 & 6,3 & 2,6 & & 4,6 & 2,6 \\
\hline - Rente & & 3,3 & 4,7 & 2,0 & & 3,4 & 2,0 \\
\hline Totaal jaarkosten & $(C / d p l)$ & 19 & 40 & 11 & & 19 & 11 \\
\hline C per kg & & c 0,06 & C 0,12 & C 0,03 & $\boldsymbol{c}$ & 0,06 & C 0,03 \\
\hline
\end{tabular}




\section{Bijlage 14 Vragenlijst enquête kalverhouders}

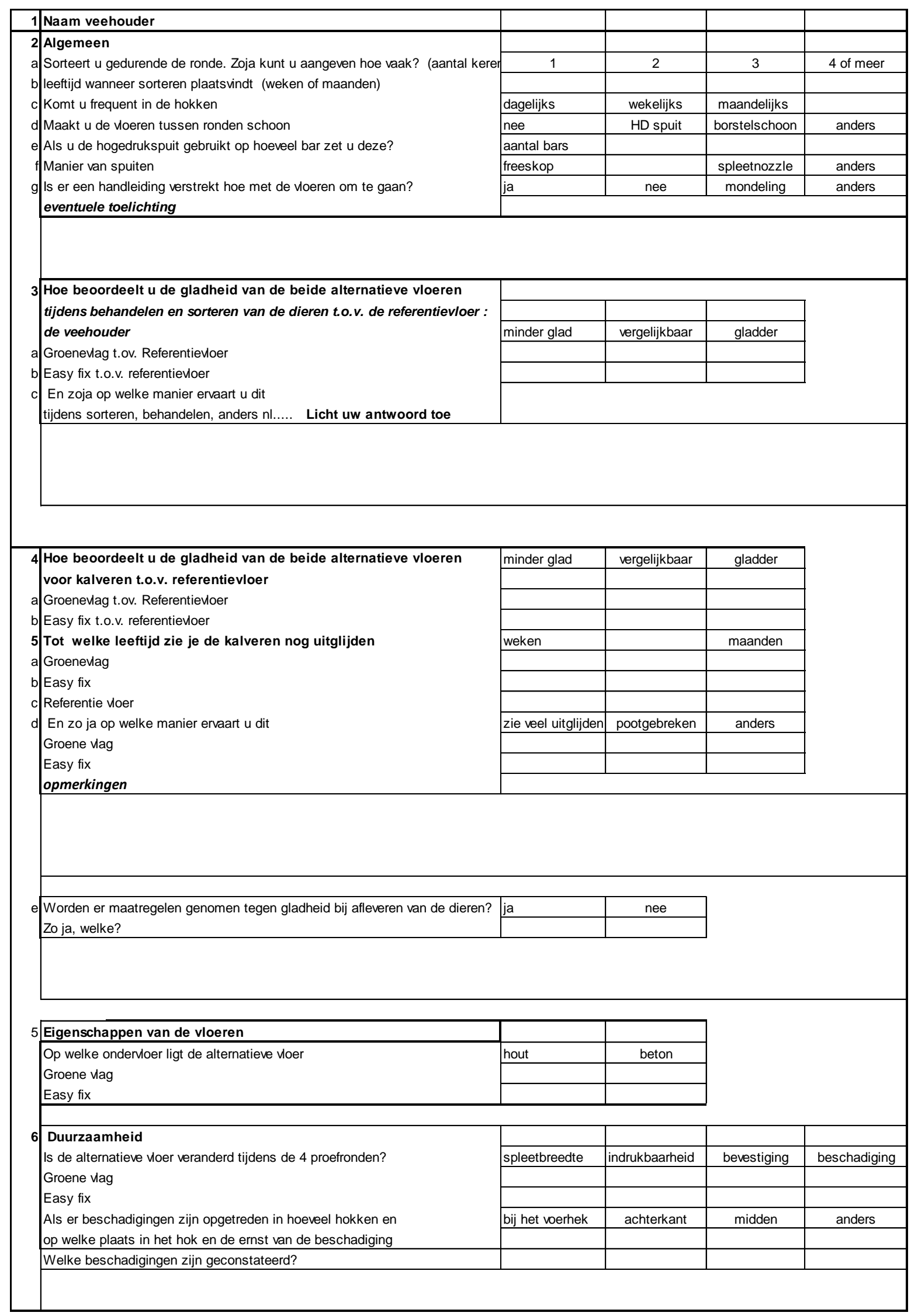




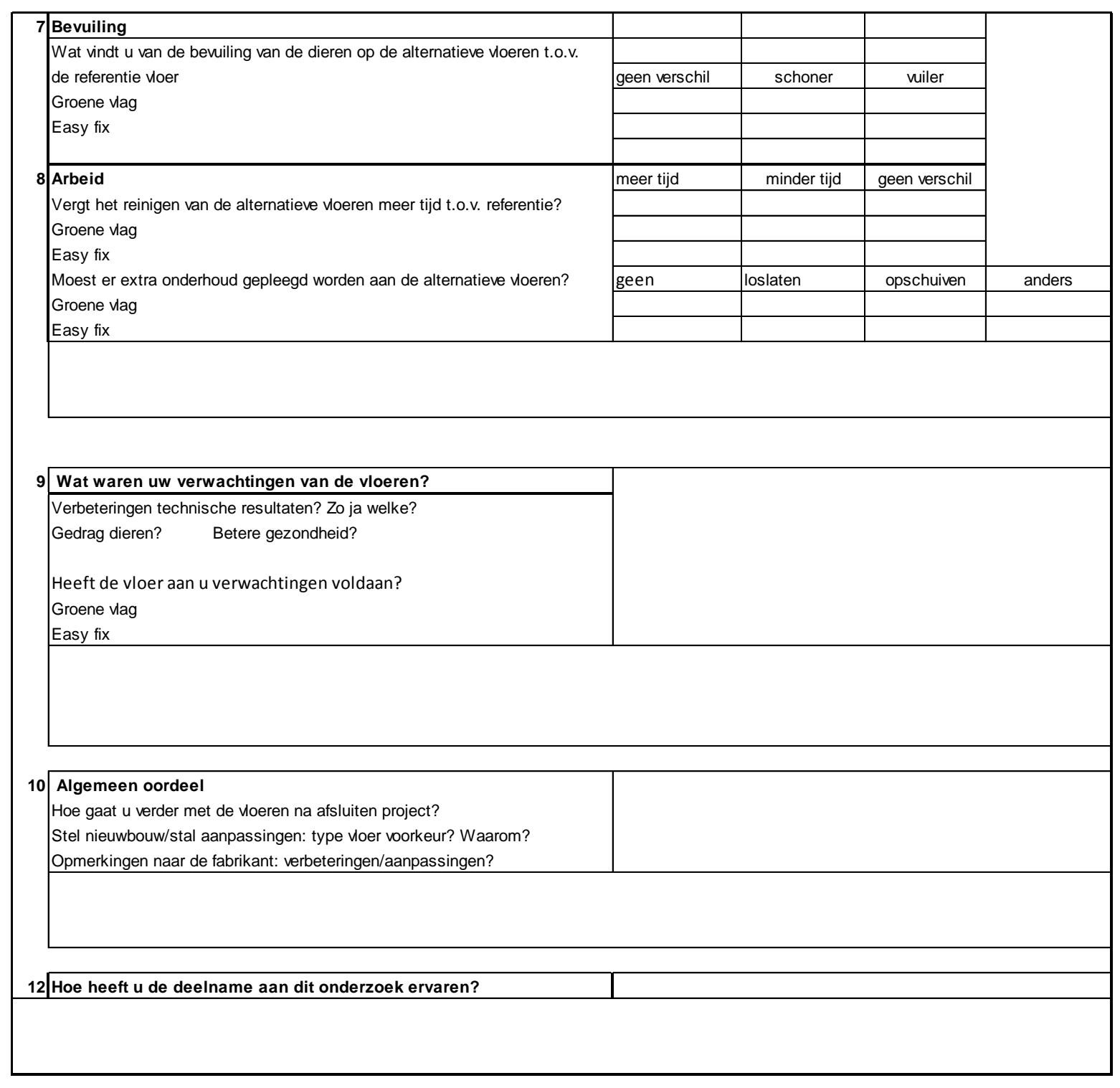





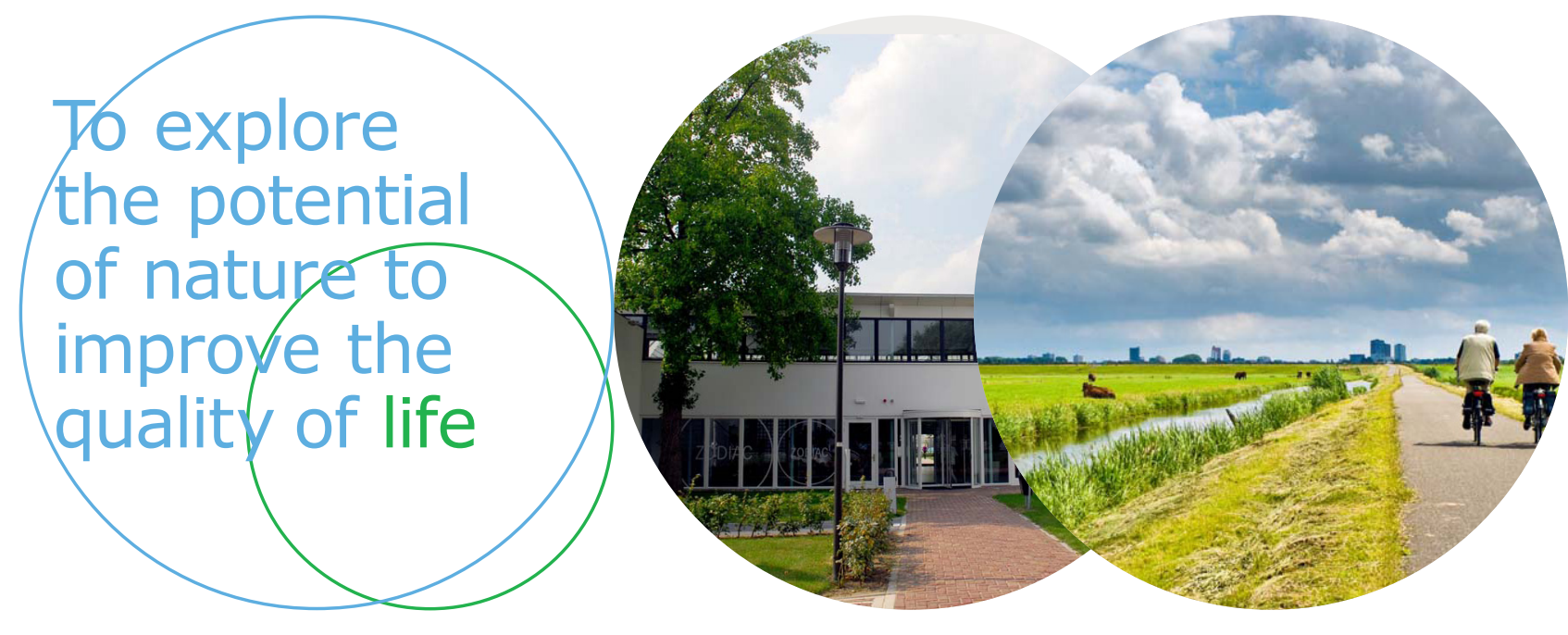

Wageningen Livestock Research Postbus 338 6700 AH Wageningen

T 0317483953

E info.livestockresearch@wur.nl www.wur.nl/ livestock-research
Wageningen Livestock Research ontwikkelt kennis voor een zorgvuldige en renderende veehouderij, vertaalt deze naar praktijkgerichte oplossingen en innovaties, en zorgt voor doorstroming van deze kennis. Onze wetenschappelijke kennis op het gebied van veehouderijsystemen en van voeding, genetica, welzijn en milieu-impact van landbouwhuisdieren integreren we, samen met onze klanten, tot veehouderijconcepten voor de 21 e eeuw.

De missie van Wageningen University \& Research is 'To explore the potential of nature to improve the quality of life'. Binnen Wageningen University \& Research bundelen 9 gespecialiseerde onderzoeksinstituten van Stichting Wageningen Research en Wageningen University hun krachten om bij te dragen aan de oplossing van belangrijke vragen in het domein van gezonde voeding en leefomgeving. Met ongeveer 30 vestigingen, 6.500 medewerkers en 10.000 studenten behoort Wageningen University \& Research wereldwijd tot de aansprekende kennisinstellingen binnen haar domein. De integrale benadering van de vraagstukken en de samenwerking tussen verschillende disciplines vormen het hart van de unieke Wageningen aanpak. 